\title{
INFLUÊNCIA DE SISTEMAS DE MANEJO EM CARACTERÍSTICAS DE TANGERINA 'PONCÃ' SOBRE LIMÃO ‘CRAVO' E DE UM LATOSSOLO ROXO
}

\section{CARMEN SILVIA VIEIRA JANEIRO NEVES}

Engenheira Agrônoma

Orientador: Prof. Dr. ANTONIO ROQUE DECHEN

\footnotetext{
Tese apresentada à Escola Superior de Agnncuitura

"Luiz de Queiroz", Universidade de São Paulo, para obtenção do título de Doutor em Agronomia, Área de Concentração: Solos e Nutrição de Plantas.
}

PIRACICABA

Estado de São Paulo - Brasil

Janeiro - 1998 
Dados Internacionais de Catalogação na Publicação (CIP) DIVISÃO DE BIBLIOTECA E DOCUMENTAÇÃO - Campus "Luiz de Queiroz"/USP

Neves, Carmen Silvia Vieira Janeiro

Influência de sistemas de manejo em caracteristicas de tangerina 'Poncā' sobre limão 'Cravo' e de um latossolo roxo / Carmen Silvia Vieira Janeiro Neves. - Piracicaba, 1998.

$158 \mathrm{p}$.

Tese (doutorado) - - Escola Superior de Agricultura Luiz de Queiroz, 1998. Bibliografia.

1. Citricultura 2. Latossolo roxo 3. Limão cravo 4. Manejo de solo 5. Tangerina poncā l. Título

CDD 634.3 


\title{
INFLUÊNCIA DE SISTEMAS DE MANEJO EM CARACTERÍSTICAS DE TANGERINA 'PONCÃ' SOBRE LIMÃO 'CRAVO' E DE UM LATOSSOLO ROXO
}

\author{
CARMEN SILVIA VIEIRA JANEIRO NEVES
}

Aprovada em: 05.03.1998

Comissão julgadora:

Prof. Dr. Antonio Roque Dechen

Prof. Dr. Francisco Antonio Monteiro

Prof. Dr. Francisco Assis Alves Mourão Filho

Prof. Dr. Christian Feller

Prof ${ }^{a}$. Dr ${ }^{\mathrm{a}}$. Maria de Fátima Guimarães
ESALQ/USP

ESALQ/USP

ESALQ/USP

ORSTOM

UEL
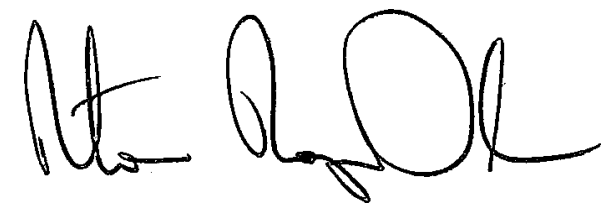

Prof. Dr. ANTONIO ROQUE DECHEN

Orientador 
Este trabalho é dedicado

a meus pais, que não mediram esforços para minha formação, a meu marido, pela compreensão e apoio e aos nossos filhos, fonte de constante aprendizado. 


\section{Agradecimentos}

Meus sinceros agradecimentos às pessoas e instituições que tornaram possivel a realização deste trabalho:

Ao Prof. Dr. Antonio Roque Dechen, pela orientação, confiança e amizade.

Ao Dr. Christian Feller, pela acolhida durante a permanência em Montpellier, orientação e sugestões.

À Prof. Dra. Sonia Maria de Stefano Piedade, do Departamento de Matemática e Estatística da ESALQ, pelo auxílio nas análises estatísticas; ao Prof. Dr. Vinícius Castro Souza, do Departamento de Botânica da ESALQ, pela identificação das espécies de cobertura vegetal, à Dra. Brigitte J. Feigl, do CENA, pelas análises de nitrogênio no solo e ao Dr. Michel Fortier, do CIRAD pelas análises de porosidade a mercúrio.

Aos colegas: Cristiane de Conti Medina, Darlot Alves da Silva Junior, João Tavares Filho, Maria de Fátima Guimarães, Otávio Jorge Abi Saab e Ricardo Ralisch, pelo auxílio nas avaliações de campo; Lúcio André de Castro Jorge, pela orientação nas imagens de raízes; Fernando Luiz Dultra Cintra, Maria do Rosário Lobato Rodrigues e Pedro Luiz de Freitas, pelas sugestões e apoio; Ângelo Jacomino, Deonísio Destro, Eduardo Firmino Carlos, Maria Gloria Nilo Gonzalez, Maurício Ursi Ventura e Neusa Colauto Stenzel, pela colaboração na disciplina de Fruticultura da Universidade Estadual de Londrina, durante o período do curso de Doutorado.

À Universidade Estadual de Londrina e à Escola Superior de Agricultura "Luiz de Queiroz", pela oportunidade da realização do curso; à CAPES, pela bolsa de estudos e ao ORSTOM (Institut Français de Recherche Scientifique pour le Dévelopment en Coopération)/ LCSC (Laboratoire de Comportement des Sols Cultivés) - Montpellier, pela oportunidade de realização de estágio "doutorado-sandwich".

Aos funcionários do Departamento de Agronomia da UEL; Departamento de Química da ESALQ; Laboratório de Fertilidade do Solo do CENA; Biblioteca Central da ESALQ; e LCSC/ORSTOM. 


\section{APRESENTAÇÃO}

A presente Tese foi redigida em "Forma de Publicação", de acordo com as Normas para Elaboração de Dissertações e Teses da ESALQ/USP (1997) e é composta pelos seguintes trabalhos cientificos:

- Manejo de solo em pomar de tangerina 'Poncã' em Londrina, PR e sua influência no estado nutricional das plantas, produção, qualidade dos frutos e características químicas do solo.

- Efeito do manejo do solo no sistema radicular de tangerina 'Poncã' enxertada sobre limão 'Cravo' e em atributos físicos de um latossolo roxo.

- Efeito de cobertura de solo de pomar cítrico com vegetação espontânea ou leguminosa no fracionamento granulométrico da matéria orgânica de um latossolo roxo.

- Efeito do manejo do solo e da matéria orgânica solúvel em água quente na estabilidade de agregados de um latossolo roxo.

Antecedendo a apresentação dos referidos trabalhos encontram-se uma Introdução e uma Revisão de Literatura de caráter geral. 


\section{SUMÁRIO}

Página

RESUMO

SUMMARY $\mathbf{x}$

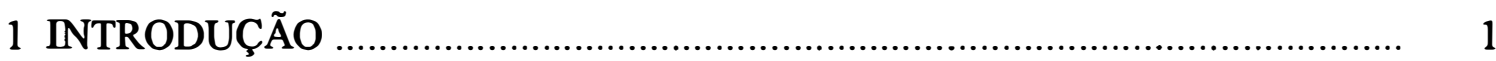

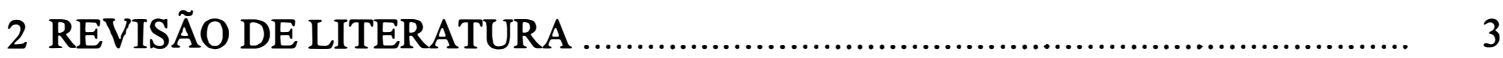

2.1 Manejo do solo do pomar e sua influência na produção, qualidade dos frutos e nutrição das plantas cítricas

2.2 Sistema radicular das plantas cítricas

2.3 Manejo do solo em pomares cítricos e sua influência nas característias físicas e químicas do solo

2.4 Fracionamento granulométrico da matéria orgânica do solo

3 MANEJO DE SOLO EM POMAR DE TANGERINA 'PONCÃ' EM LONDRINA, PR E SUA INFLUÊNCIA NO ESTADO NUTRICIONAL DAS PLANTAS, PRODUÇÃO, QUALIDADE DOS FRUTOS E CARACTERÍSTICAS QUÍMICAS DO SOLO

3.1 Resumo

3.2 Summary

3.3 Introdução

3.4 Material e Métodos

3.5 Resultados e Discussão

3.6 Conclusões

4 EFEITO DO MANEJO DO SOLO NO SISTEMA RADICULAR DE TANGERINA 'PONCÃ' ENXERTADA SOBRE LIMÃO 'CRAVO' E EM ATRIBUTOS FÍSICOS DE UM LATOSSOLO ROXO

4.1 Resumo

4.2 Summary

4.3 Introdução 


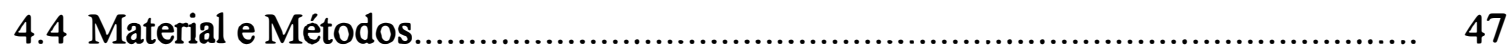

4.5 Resultados e Discussão.............................................................................. 53

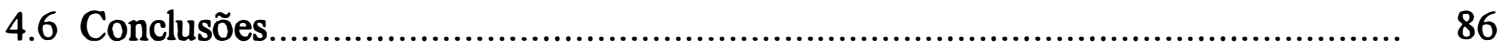

5 EFEITO DE COBERTURA DE SOLO DE POMAR CÍTRICO COM VEGETAÇÃO ESPONTÂNEA OU LEGUMINOSA NO FRACIONAMENTO GRANULOMÉTRICO DA MATÉRIA ORGÂNICA DE UM LATOSSOLO

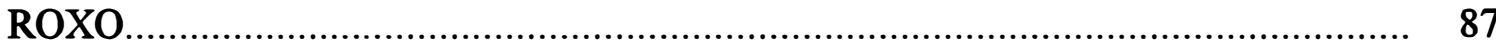

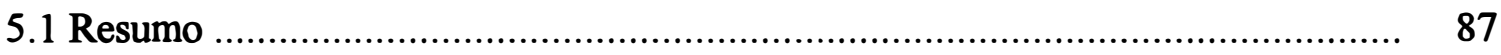

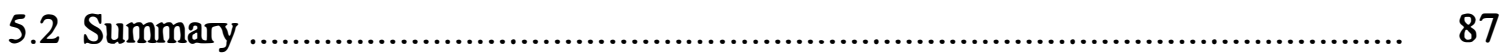

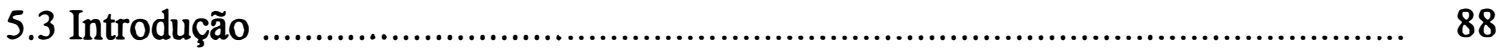

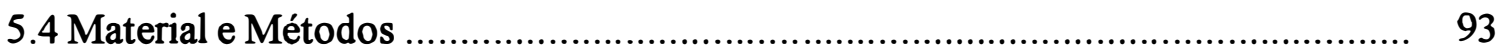

5.5 Resultados e Discussão …….................................................................. 95

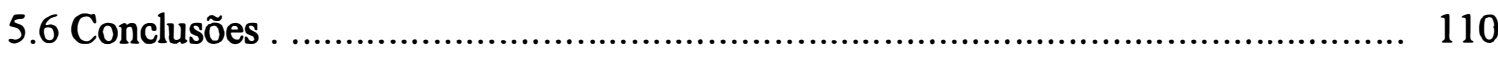

6 EFEITO DO MANEJO DO SOLO E DA MATÉRIA ORGÂNICA SOLÚVEL EM ÁGUA QUENTE NA ESTABILIDADE DE AGREGADOS DE UM

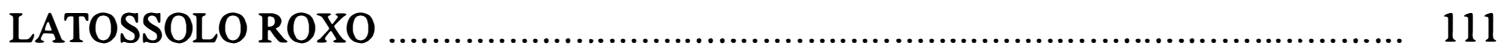

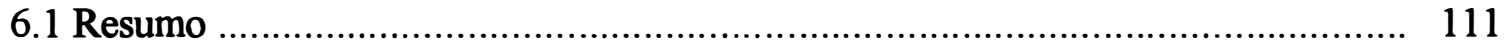

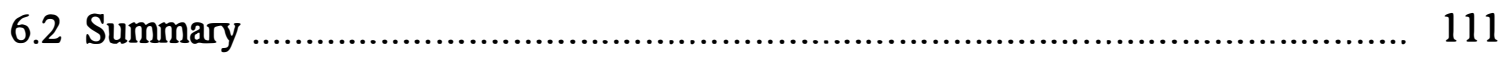

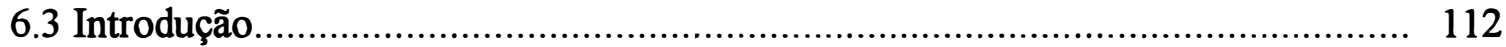

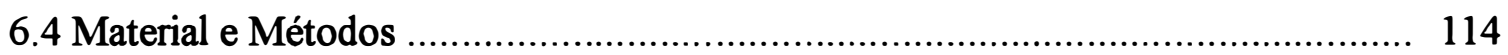

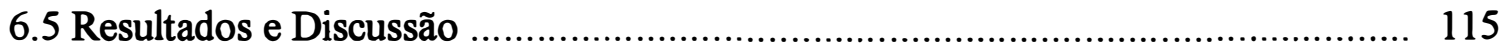

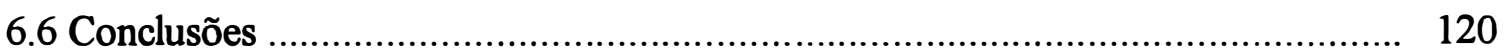

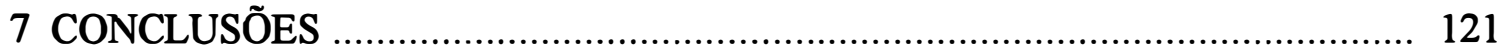

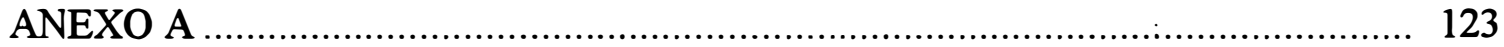

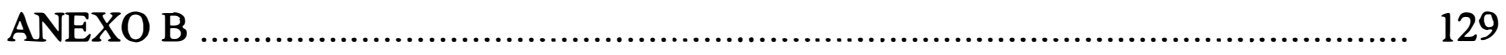

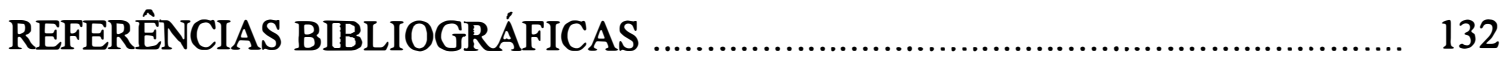

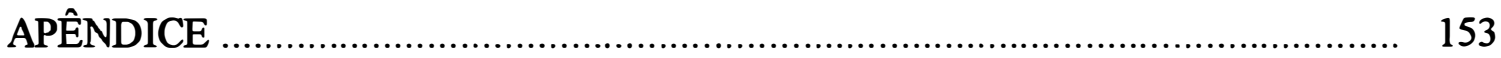




\title{
INFLUÊNCIA DE SISTEMAS DE MANEJO EM CARACTERÍSTICAS DE TANGERINA 'PONCÃ' SOBRE LIMÃO 'CRAVO’ E DE UM LATOSSOLO ROXO
}

\author{
Autora: CARMEN SILVIA VIEIRA JANEIRO NEVES \\ Orientador: Prof. ANTONIO ROQUE DECHEN
}

\section{RESUMO}

Em um pomar de tangerina 'Poncã' (Citrus reticulata Blanco) enxertada sobre limão 'Cravo' (Citrus limonia Osbeck) em latossolo roxo, em Londrina-PR, foram testados cinco tratamentos de manejo do solo: cobertura verde durante todo o ano com a leguminosa Indigofera campestris Benth.; cobertura verde durante todo o ano com a leguminosa Arachis prostrata Bong. ex Benth.; cobertura durante a época de chuvas com mucuna cinza - Stizolobium pruriens; uso alternado de roçadeira ( três a quatro vezes no período de chuvas) e de uma gradagem a disco (no período seco); capina manual o ano inteiro. Os tratamentos permaneceram no campo durante nove anos. A produção, a qualidade dos frutos e a nutrição das plantas não foram significativamente afetadas pelos tratamentos.

A quantidade total de raízes, avaliada pelo método da trincheira, não apresentou diferenças entre os tratamentos, mas a distribuição do sistema radicular foi significativamente alterada. A presença de $A$. prostrata provocou concentração e aprofundamento das raízes. O perfil cultural indicou zonas de compactação nos 
tratamentos Roçadeira/Grade e Capina. A ocorrência das raízes dos citros foi observada tanto nas zonas compactadas como nas não compactadas do perfil.

Para o estudo da matéria orgânica do solo e da estabilidade de agregados, foram escolhidos três tratamentos do pomar (Arachis prostrata, roçadeira/grade, capina manual) e como referência utilizou-se o mesmo solo sob floresta nativa e sob culturas anuais. $\mathrm{O}$ teor de matéria orgânica do solo do pomar foi aumentado com as coberturas de A. prostrata e gradagem/ roçadeira. As perdas de carbono (em $\mathrm{mg} \mathrm{C} \mathrm{g}^{-1}$ de solo) na camada $0-10 \mathrm{~cm}$ quando o solo passou da vegetação nativa para as culturas, foram de 12 a $45 \%$, sendo maiores com culturas anuais por 20 anos. A fração que mais perdeu matéria orgânica foi a fração resíduos vegetais (200-2.000 $\mu \mathrm{m})$. A maior proporção da matéria orgânica do solo encontrou-se na fração organo-argilosa (0-2 $\mu \mathrm{m})$, com 34 a 43 $\%$ do total, seguida da fração organo-siltosa $(2-20 \mu \mathrm{m})$, com 23 a $28 \%$ do total.

A estabilidade de agregados foi determinada em amostras submetidas ou não ao tratamento para retirada da matéria orgânica solúvel em água quente. A vegetação de floresta proporcionou maior estabilidade, seguida da situação de pomar submetido à cobertura com $A$. prostrata ou roçadeira/grade. A extração com água quente do carbono solúvel não provocou diferenças significativas na estabilidade dos agregados. 


\title{
EFFECT OF ORCHARD MANAGEMENT SYSTEMS ON CHARACTERISTICS OF 'PONCÃ' TANGERINE ON 'RANGPUR' LIME AND OF AN OXISOL
}

\author{
Author: CARMEN SILVIA VIEIRA JANEIRO NEVES \\ Adviser: Prof. ANTONIO ROQUE DECHEN
}

\section{SUMMARY}

A trial with 'Poncã' tangerine (Citrus reticulata Blanco) on 'Rangpur Lime' rootstock was carried out in Londrina-PR on an oxisol to study the effect of orchard floor management on plant yield, nutrition, fruit quality and soil chemical and physical characteristics. Five treatments were used: permanent cover with Indigofera campestris Benth; permanent cover with Arachis prostrata Bong. ex Benth; 'mucuna cinza' (Stizolobium pruriens) during spring and summer; alternate mowing (rainy season) /tillage (dry season); and vegetation-free (by hand hoeing). After nine years, yield, fruit quality and plant nutrition were not affected by treatments.

The total amount of citrus roots, observed by the profile wall method, was not affected by soil management treatments. The presence of perenial leguminous plants in the orchard inter-row limited the presence of citrus roots to the region of the profile where roots of the cover plants were absent. This was compensated by a significant increase in citrus root system deepning in $A$. prostrata treatment. The cultural profile showed regions with high soil bulk density in the treatments mowing/tillage and hand 
hoeing, but citrus roots grew in that regions as well as in the others with low soil bulk density.

Three treatments were chosen to study soil organic matter and water-stable aggregates: $A$. prostrata, mowing/tillage and vegetation-free. The tests were also made in samples of the same soil under native forest and under annual crops. The total organic matter of the soil was increased with the treatments $A$. prostrata and mowing/ tillage. The losses of carbon in the layer $0-10 \mathrm{~cm}$ when the soil passed from the native vegetation to the crops went from 12 to $45 \%$, being larger with annual crops for 20 years. For all situations, the largest proportion of the soil organic matter was found in the organo-clay fraction $(0-2 \mu \mathrm{m})$ with 34 to $43 \%$ of the total, followed by the organo-silt fraction (2-20 $\mu \mathrm{m})$ with 23 to $28 \%$ of the total. With the introduction of the crops, the fraction that lost most organic matter was $200-2.000 \mu \mathrm{m}$ fraction, in the two studied depths.

The aggregate stability was determined in samples submitted or not to a treatment water to remove hot-water soluble organic matter. The forest vegetation provided larger stability, followed by the orchard situation submitted to the permanent covering or mowing/tillage. Extraction of hot-water soluble carbon did not cause significant changes in aggregate stability. 
1 INTRODUÇÃO 


\section{INTRODUÇÃo}

A cultura dos citros no Brasil possui importância tanto pela área ocupada quanto pela quantidade produzida. O país ocupa posição de destaque no panorama internacional como o principal produtor de frutas cítricas e de suco concentrado congelado, sendo que o Estado de São Paulo contribui com cerca de $80 \%$ do total de frutos cítricos produridos.

No Estado do Paraná, até a década de 80 a citricultura ficou restrita à região do Alto Ribeira, próxima a Curitiba, em função da ocorrência de cancro cítrico e conseqüente proibição do plantio de plantas cítricas nas regiões Norte, Noroeste e Oeste do Estado, mais apropriadas climaticamente, para a produção de citros. Com os estudos sobre cultivares resistentes ao cancro cítrico, mudanças nos critérios para liberação de áreas para o plantio de citros, apoio governamental e interesse por parte de agricultores e cooperativas, iniciou-se a implantação de um parque citrícola tecnificado e intensivo, principalmente nas regiões Norte e Noroeste.

Com a entrada nesta nova fase da citricultura paranaense, a adaptação e o teste de técnicas adequadas às condições do Estado se impuseram. Neste contexto, instalou-se em 1985, no campus da Universidade Estadual de Londrina, um pomar de tangerina 'Poncã', visando o teste de vários sistemas de manejo de solo. Na ocasião, duas espécies de leguminosas perenes começavam a ser usadas como cobertura de solo em pomares paranaenses, as quais foram incluídas neste estudo, bem como o sistema de manejo do solo mais usado no Estado de São Paulo.

Resultados da literatura, de forma geral, informam que os sistemas de manejo que são mais benéficos à produção dos pomares são aqueles em que a competição por 
água e nutrientes é minimizada, restringindo a ocorrência de outras plantas na área, pelo menos nos períodos mais críticos do ano. Por outro lado, os estudos indicam também que nem sempre o sistema mais produtivo do ponto de vista da cultura é o mais interessante sob o aspecto da manutenção das boas condições do solo. Além disso, os resultados são muitas vezes conflitantes, com desempenhos diferentes para um mesmo sistema em locais diferentes ou mesmo com falta de constância ao longo dos anos de observação para determinado sistema em um mesmo local. É importante, então, buscar respostas regionais, adaptadas a cada caso, buscando-se atingir a melhor rentabilidade possível, causando o mínimo de perda dos atributos do solo, possibilitando a produção a longo prazo e não apenas pelo curto espaço de tempo da vida útil de um pomar.

$O$ presente trabalho teve o objetivo de estudar o comportamento de um pomar de tangerina 'Poncã' enxertada sobre limão 'Cravo' sob a influência de sistemas de manejo de solo, que foram mantidos desde a implantação do pomar. Os tratamentos incluíram coberturas verdes com leguminosas recomendadas para o Estado do Paraná.

Os estudos constaram de avaliações do comportamento das plantas cítricas e do solo: produção anual e a qualidade dos frutos (peso, teor de sólidos solúveis, acidez e relação sólidos solúveis/acidez), estado nutricional das plantas, distribuição do sistema radicular, análise química do solo, análise da matéria orgânica do solo e análise de alguns atributos fisicos do solo (densidade, porosidade, estabilidade de agregados, perfil cultural). 
2 REVISÃO DE LITERATURA 


\section{REVISÃO DE LITERATURA}

\subsection{Manejo do solo do pomar e sua influência na produção, qualidade dos frutos e nutrição das plantas cítricas}

A maneira como se maneja o solo do pomar influencia o desenvolvimento vegetativo, a sanidade e a produtividade da cultura, bem como as condições fisicas, químicas e biológicas do solo.

As práticas culturais utilizadas para o manejo do solo em pomares podem ser reunidas em quatro grupos básicos (Hoghe \& Nielsen, 1987): vegetação permanente (controlada com ceifa), cobertura morta, cultivo mecânico e herbicidas. Para os pomares cítricos, Jones \& Embleton (1973) classificaram as práticas de manejo em quatro grupos: solo mantido limpo através de cultivo mecânico, uso de plantas de cobertura durante o inverno, uso de plantas de cobertura durante o verão, e "no-tillage", que pode ser realizado através de vegetação natural espontânea, ou eliminação das ervas invasoras através de cultivo manual ou herbicidas. Segundo os últimos autores, a escolha de determinada prática deve ser feita a partir das características do solo, pluviometria, tipo de ervas invasoras e fatores locais, mas a opção por determinado sistema é muitas vezes mais baseada na tradição do uso do que em princípios estabelecidos por resultados experimentais.

No Brasil, os sistemas mais usados para reduzir a competição com as ervas daninhas da cultura dos citros são o uso da grade de disco na entrelinha de plantio e o coroamento com enxada na linha (Victoria Filho, 1988) e o emprego de roçadeira nas entrelinhas da cultura, em três a quatro vezes durante o período chuvoso e uma 
gradeação no período seco e nas linhas de plantio é feita uma capina com enxada ou herbicida (Caetano, 1985; Negri, 1988; Coelho, 1991). Para Caetano (1980, 1985), na escolha do sistema de manejo de solo do pomar, nas condições do Estado de São Paulo, deve-se levar em consideração que a região possui duas estações climáticas bastante características: um período seco (abril a agosto) e outro chuvoso (setembro a março). Assim, é aconselhável que o pomar permaneça no limpo no período seco, enquanto que na estação chuvosa deve ser mantida uma cobertura de mato nas entrelinhas, para evitar erosão.

A grade de discos para o controle do mato nos pomares é eficiente pois realiza um trabalho agressivo, incorporando as ervas (Coelho, 1991). Entretanto, esse mesmo autor salientou que em relação ao solo, a desvantagem do uso da grade está na compactação mecânica das camadas de solo abaixo da superficie, o que pode favorecer a erosão hídrica, além de reduzir os teores de oxigênio e água do solo, impedindo o pleno crescimento do sistema radicular. Uma desvantagem adicional é o dano provocado às raízes das plantas cítricas. Em função destes aspectos, o autor recomendou o uso da grade de discos em apenas uma ou duas operações ao ano, e numa profundidade de no máximo sete centímetros. De acordo com Moreira (1983b), a maior parte do sistema radicular das plantas cítricas se localiza próximo à superficie do solo e por isso esse autor alertou para que não se façam gradagens no pomar a profundidades maiores que cinco centímetros.

Para reduzir os riscos de erosão nos pomares, de acordo com Castro \& Lombardi Neto (1992), é de fundamental importância que se aumente a cobertura vegetal do solo, seja com culturas, resíduos culturais ou de mato ou com adubos verdes. No caso dos adubos verdes, além da proteção do solo ocorrem os seguintes beneficios: redução da necessidade de capinas, baixo custo de implantação, melhoria da infiltração do solo e ausência de competição, pois as leguminosas são cultivadas normalmente na época chuvosa. Em função disso, segundo esses autores, não se tem observado redução na produção de frutas cítricas a longo prazo, chegando, em alguns casos, a ocorrer um aumento. Da mesma forma, Demattê \& Vitti (1992) recomendaram o controle das ervas 
invasoras sem o uso da grade e com associação de leguminosas nas entrelinhas para reduzir a compactação e aumentar a infiltração de água e citaram a Crotalaria juncea e o guandu (Cajanus cajan) como espécies que têm se destacado para esse uso.

No Estado do Paraná, para o manejo do solo dos pomares cítricos são recomendadas espécies de leguminosas de ciclo temporário: mucuna anã, mucuna cinza, e crotalárias (Crotalaria breviflora, C. spectabilis, C. mucronata, ou C. grantiana) ou de ciclo permanente: calopogônio (Calopogonium mucunoides), centrosema (Centrosema pubescens), grama amendoim (Arachis sp.) e indigofera (Indigofera sp.) (Rufino et al., 1992; Calegari, 1995).

Braga (1986) salientou que o manejo do adubo verde deve ser adequado à idade das plantas de citros. Assim, esse autor indicou que na fase de implantação do pomar, até o terceiro ano, o espaço intercalar deve ser ocupado preferencialmente por uma cultura de valor econômico, que minimize os custos de implantação, como a soja (Glycine mox), que torna-se fonte de nitrogênio residual, obtido simbioticamente. A partir do quarto ano, a adubação verde pode ser implantada, ajustando-se sua faixa de cobertura de forma a reduzir a competição com as plantas cítricas.

Vários trabalhos tem sido conduzidos no Brasil para observar o comportamento de sistemas de manejo de solo no desempenho das plantas cítricas. Um trabalho pioneiro foi realizado por Vasconcellos (1932), que utilizou duas espécies de leguminosas, feijão de porco (Canavalia ensiformis) e Clitoria ternatea, em pomares de laranjeiras com mais de 20 anos, já decadentes e pouco produtivos. O plantio foi realizado em dezembro de 1929 e a produção 1931 foi, segundo esse autor, maior do que as anteriores.

Rodriguez (1957) realizou, no planalto paulista, num pomar de laranjeira 'Hamlin' enxertada sobre laranja 'Caipira', um experimento composto dos seguintes tratamentos: solo permanentemente limpo com grade de discos, herbicida (óleo diesel), adubo verde (mucuna preta - Stizolobium sp) de outubro a abril destruída com herbicida, cobertura morta, mato natural ceifado nas águas e gradeado na seca, mucuna preta destruída com gradeação, soja perene (Neonotonia wightii) controlada através de 
gradeação, duas arações no período das águas e vegetação natural ceifada. $\mathrm{O}$ tratamento que se mostrou mais produtivo nas quatro primeiras safras foi o de cobertura morta, seguido do adubo verde gradeado. Resultados posteriores do mesmo experimento são apresentados por Caetano (1980), para seis safras. Confirmou-se a superioridade do tratamento de cobertura morta, ao qual foi atribuído o valor $100 \%$, seguida de adubo verde gradeado (com 68\%), solo permanentemente limpo através de gradeação (62\%), soja-perene (57\%), adubo verde destruído com herbicida (55\%) ou duas arações (55\%), herbicida (52\%) e vegetação natural controlada por ceifa (44\%). Comentando estes resultados, Rodriguez et al. (1964) relataram que poder-se-ia eleger o tratamento cobertura morta permanente como o mais conveniente. No entanto, as dificuldades de sua realização continuada, além de representar constante perigo de incêndio, fizeram com que este sistema de manejo fosse aconselhado apenas para casos especiais em que sua execução fosse facilitada.

Rodriguez (1969) comparou, em São Paulo, três sistemas de controle das ervas daninhas em pomar de laranja 'Hamlin' enxertada sobre laranja 'Caipira': vegetação natural ceifada duas vezes por ano, adubação verde de guandu (que depois de três anos foi substituído por soja-perene) e ceifa duas vezes no período chuvoso mais uma gradeação no início do período seco. Os tratamentos não tiveram comportamento uniforme ao longo dos anos. Com os resultados de oito safras, esse autor concluiu que as maiores produções foram obtidas com o tratamento de adubo verde, seguido do tratamento de ceifa mais gradeação. Estes dois sistemas produziram, respectivamente, $29 \%$ e $18 \%$ a mais do que o tratamento de mato ceifado

O desempenho de quatro sistemas de manejo de solo foi avaliado no Rio Grande do Sul por Dornelles (1971). Esse autor observou que o pior tratamento do ponto de vista da produção de seis variedades de laranjeiras enxertadas sobre laranjadoce comum foi o de ceifa durante o ano todo, enquanto que os demais (ceifa no inverno mais cultivo no verão, vegetação espontânea no inverno mais cultura de verão, cultivo durante todo o ano) não apresentaram diferenças entre si. 
Passos et al. (1973), em solo arenoso de tabuleiro no Estado da Bahia, avaliaram o comportamento das plantas de laranja 'Baianinha' enxertadas sobre limão 'Cravo' do quinto ao sétimo ano. Constataram que as produções não tiveram o mesmo comportamento para cada tratamento, nos anos de observação. No quinto ano o melhor desempenho foi o do tratamento grade no verão mais ceifa no inverno; no ano seguinte a maior produção foi obtida com grade permanente; enquanto que no sétimo ano o melhor foi adubação verde com Calopogonio mucunoides. Assim, na média dos três anos avaliados estes tratamentos apresentaram produtividades semelhantes. As produções mais baixas foram obtidas com ceifadeira permanente e com culturas intercalares de mandioca (Manihot utilissima), fumo (Nicotiana tabacum), amendoim (Arachis hypogaea) e feijãomacassar (Vigna sinensis (L.) Savi), mesmo sendo produzidas apenas nos primeiros anos de formação do pomar. Esses autores frisaram, entretanto, que os resultados, por serem preliminares, necessitavam de repetições por mais algumas safras.

Pacheco et al. (1973), em latossolo vermelho-amarelo fase cerrado em Minas Gerais, observaram o efeito de sete práticas de manejo do solo em pomar de laranja 'Baianinha' enxertada sobre limão 'Cravo'. Para a primeira safra, os tratamentos cobertura morta e gradagens superficiais resultaram em maior produção, enquanto que para a segunda safra estes mesmos tratamentos, bem como o tratamento caupi gradeado no florescimento, induziram produções significativamente maiores que os demais. Os piores desempenhos foram para os tratamentos de vegetação natural ceifada e sojaperene ceifada ou com colheita de sementes, enquanto que o tratamento caupi ceifado teve um comportamento intermediário. Esses autores, entretanto, alertaram para o fato de que, em início da vida produtiva, as plantas ainda não mostravam uniformidade de produção.

No Rio de Janeiro, em um experimento composto de seis tipos de manejo de solo podzólico vermelho-amarelo, avaliou-se a produção e a qualidade dos frutos de laranja 'Pêra' enxertada sobre limão 'Cravo' (Vasconcellos et al., 1976). Para uma média de cinco safras, constatou-se a superioridade do tratamento gradagem, que não diferiu de cobertura morta. Os tratamentos capinas periódicas e adubação verde com Pueraria 
javanica e Centrosema pubescens tiveram desempenho intermediário, enquanto que o herbicida pentaclorofenol foi o que ocasionou menor produção. Quanto à qualidade dos frutos, os manejos com capina, cobertura morta, herbicida e gradagem tiveram significativamente maior porcentagem de suco do que os demais. $\mathrm{O}$ teor de sólidos solúveis foi significativamente mais elevado no tratamento $C$. pubescens ou herbicida $\mathrm{e}$ menor com cobertura morta em relação aos demais. A acidez total não apresentou diferenças significativas.

Koller et al. (1977), no Rio Grande do Sul, estudaram o comportamento de um pomar de laranjas 'Valência' e 'Baianinha' enxertadas sobre laranja 'Caipira'. O solo foi mantido sem vegetação durante a primavera e o verão, mediante uma aração e três gradagens ao ano, ou mantido com vegetação nativa, ceifada periodicamente. Este último tratamento reduziu significativamente a produção das plantas (média de seis anos), mas a qualidade dos frutos, em termos de tamanho, teores de sólidos solúveis e acidez, não foi afetada.

Donadio et al. (1986) relataram os resultados preliminares de um experimento de manejo de solo realizado em Bebedouro - SP, em latossolo vermelho-escuro, com laranjeira 'Hamlin' enxertada sobre limão 'Cravo'. Os tratamentos constaram de capina, herbicida de contato (paraquat), adubação verde (lab-lab, Dolichos lab-lab e mucuna preta, Stilozobium aterrinium), herbicida pré-emergência (diuron) e gradeação. Na média das duas primeiras safras esses autores constataram que as maiores produções foram obtidas nos tratamentos de herbicida de pré-emergência e capina. Esta tendência foi confirmada em resultados posteriores (São José et al., 1988), na média das três primeiras safras e no diâmetro dos troncos.

Carvalho et al. (1995) realizaram um estudo com laranja 'Pera' com sete anos de idade, na Bahia, onde testaram nove práticas de cultivo do solo e sua influência na produção de frutos e na quantidade de fungos micorrízicos presentes nas raízes. Para a produção de frutos, esses autores avaliaram a primeira safra depois da instalação do experimento e obtiveram diferenças significativas. $\mathrm{O}$ tratamento mais produtivo foi o de capina nas linhas mais gradagem nas entrelinhas na época seca e ceifa na época das águas. 
Este tratamento, entretanto, não diferiu estatisticamente de herbicida glifosate nas linhas e feijão de porco (Canavalia ensiformis) nas entrelinhas, e de capinas nas linhas mais gradagens nas entrelinhas da cultura, capinas nas linhas mais ceifas nas entrelinhas, oxyfluoren nas linhas mais ceifa nas entrelinhas, diuron nas linhas mais ceifa nas entrelinhas, e ceifa lateral nas linhas mais gradagens nas entrelinhas. Os piores desempenhos foram obtidos com glifosate nas linhas mais ceifa nas entrelinhas e com diuron mais glifosate nas linhas mais ceifa nas entrelinhas. Em relação à nutrição, os tratamentos não exerceram influência nos teores de nutrientes nas folhas.

Silva (1995), em pomar de laranja 'Pera' enxertada sobre tangerina 'Cleópatra' em formação, comparou o comportamento de sete espécies de leguminosas e de adubação nitrogenada mineral. Durante os quatro primeiros anos de vida das plantas, esse autor observou que, de maneira geral, o estado nutricional das plantas foi semelhante em todos os tratamentos, tendo os adubos verdes suprido satisfatoriamente as plantas cítricas em nitrogênio. Em relação à produtividade do pomar, não houve diferenças significativas entre os tratamentos, mas os tratamentos que receberam Crotalaria juncea e Cajanus cajan (guandu) apresentaram maior produção em números absolutos.

Gallo \& Rodriguez (1960) analisaram os teores foliares de nutrientes de laranjeira 'Hamlim' enxertada sobre laranjeira 'Caipira', submetida aos seguintes tratamentos: solo limpo com herbicida (óleo diesel), adubação verde de mucuna preta, adubação verde de feijão guandu, cobertura morta de capim e arações superficiais. Esses autores observaram que a adubação verde com mucuna e a cobertura morta aumentaram significativamente o teor de fósforo nas folhas, e que este aumento teve correlação com o aumento de produção de frutos naqueles tratamentos. $\mathrm{O}$ mais baixo nível de fósforo foi obtido no tratamento de herbicida. Para o nitrogênio, os teores mais elevados foram com herbicida e adubos verdes e os menores com cobertura morta. $\mathrm{O}$ potássio foi mais elevado nos tratamentos herbicida e guandu. Para o cálcio, os maiores níveis foram atingidos com cobertura morta, mucuna e duas lavras e menores para herbicida e guandu. Para o magnésio, os níveis mais elevados ficaram com os tratamentos cobertura morta e mucuna. 
Leite \& Giacometti (1962) avaliaram a qualidade dos frutos de laranja 'Pera' enxertada sobre limão 'Cravo' quando submetidos a sistemas de manejo. Os frutos apresentaram maior peso nas parcelas tratadas com capina, cobertura morta e herbicida de contato (Shell-130). Os teores mais elevados de sólidos solúveis e acidez foram observados nos tratamentos Centrosema pubescens e capina, e os mais baixos nos tratamentos cobertura morta e herbicida. $O$ teor em suco não foi afetado pelos tratamentos.

Em outros países com condições semelhantes às brasileiras, de clima tropical $\mathrm{e}$ subtropical, estudos também têm sido realizados para avaliar o comportamento dos pomares cítricos quando submetidos a sistemas de manejo de solo. Wyss (1962) realizou um trabalho testando gradagens, cobertura morta, herbicida (dalapon) e capina em um pomar de laranja 'Valência' na Jamaica. $O$ tratamento de cobertura morta foi o que proporcionou maior produção, mas considerado pouco viável, considerando-se a rapidez da decomposição e conseqüentemente a necessidade da colocação de grandes quantidades de material orgânico para manter-se o efeito benéfico.

Bouma \& Mcintyre (1963), num experimento fatorial com citros na Austrália, envolvendo quatro níveis de adubação nitrogenada, quatro sistemas de manejo do solo, quatro combinações copa/cavalo, dois níveis de irrigação e dois níveis de calcário, não encontraram diferenças de produção para os tipos de manejo em 13 anos de experimento. Os sistemas de manejo testados foram: cultivo mecânico no verão e adubo verde no inverno, o mesmo tratamento mais esterco de curral, vegetação natural ceifada, e herbicida (querosene). Segundo esses autores, o manejo do solo teve efeito nas condições fisicas do solo mas não o suficiente para afetar o desempenho das plantas, que foi mais influenciado pelo aspecto nutricional, principalmente nitrogênio e fósforo. Entretanto, resultados preliminares do mesmo experimento (Frith, 1952) indicaram que, para as primeira safras, o tratamento de solo nu foi o mais produtivo, o mesmo acontecendo para os dados posteriores apresentados por Cary (1968). A pior produção foi a do tratamento de vegetação natural roçada, ficando o cultivo mais adubo verde em posição intermediária. Para a qualidade dos frutos, Frith (1952) não observou diferenças 
significativas para sólidos solúveis entre os tratamentos de manejo do solo. $\mathrm{O}$ tratamento ceifa provocou maior acidez e os demais não diferiram estatisticamente entre si. Análises posteriores da qualidade dos frutos foram apresentadas por Cary (1968). Para tanto, esse autor agrupou os quatro tipos de manejo de solo em dois grupos: com e sem cultivo. $\mathrm{O}$ parâmetro mais influenciado pelo manejo do solo foi o teor de suco, que foi maior no manejo com cultivo. Entretanto, este fato não ocorreu em todos os anos de observação, evidenciando que algum outro fator, provavelmente a quantidade de água disponível no solo, esteve envolvido na quantidade de suco das frutas.

Tucker et al. (1980) avaliaram durante dez anos o uso de herbicidas (bromacil e diuron) e cultivo mecânico em pomares comerciais de diversas variedades de laranjas na Flórida. Nos pomares mais novos (com oito anos) houve uma marcante superioridade de produção para o tratamento herbicida, mas nas áreas em que as plantas eram mais velhas (27 anos) não houve diferença entre a produção dos dois tratamentos. Não houve diferença significativa para o teor de sólidos solúveis e para o teor de nutrientes nas folhas.

Mustaffa (1988), em um trabalho de manejo de solo na Índia, obteve maior produção de tangerina 'Coorg' quando submetida ao tratamento de cobertura morta de folhas de floresta, e menor no tratamento de vegetação natural ceifada, provavelmente devido à competição propiciada pela vegetação natural e pela maior quantidade de água disponível no solo com cobertura morta. Em relação à qualidade dos frutos, a acidez total não foi afetada, mas o teor de sólidos solúveis foi significativamente mais elevado nos frutos do tratamento de ceifa. Com relação à nutrição das plantas, não foram verificadas diferenças significativas, mas em números absolutos o teor de nitrogênio nas folhas foi menor no tratamento ceifa do que no de cobertura morta, provavelmente pela competição por este nutriente causada pelos microorganismos na decomposição das gramíneas da vegetação natural.

Santinoni \& Silva (1995), na Argentina, estudaram o comportamento de um pomar de tangerina comum (Citrus deliciosa Tenore) enxertada sobre tangerina 'Cleópatra' quando submetido aos seguintes tratamentos: 1) Herbicida na área total; 2) 
gradagem durante todo o ano nas entrelinhas e capina nas linhas; 3) Idem a 2, com herbicida nas linhas; 4) Alfafa (Medicago sativa) para corte nas entrelinhas e herbicida nas linhas; 5) Gramínea perene (Chloris gayana Kunth.) roçada nas entrelinhas e capina nas linhas; 6) Idem a 5, com herbicida nas linhas; 7) Leguminosa no verão (Vigna sinénsis L.) e gramínea no inverno (Hordeum vulgare L.) nas entrelinhas e herbicida nas linhas; 8) Leguminosa no inverno (Vicia sativa $\mathrm{L}$.) e roçadeira no resto do ano nas entrelinhas e herbicida nas linhas. Os autores obtiveram, para a produção acumulada de 6 safras, a melhor produtividade com o tratamento 3 , que não diferiu estatisticamente dos tratamentos 1,2,6,7 e 8. O pior desempenho foi do tratamento 5 e o tratamento 4 teve desempenho intermediário. Para a qualidade dos frutos (rendimento em suco e relação sólidos solúvies/acidez) os tratamentos tiveram resultados equivalentes.

\subsection{Sistema radicular das plantas cítricas}

De acordo com Castle et al. (1989), o conhecimento sobre a taxa de crescimento, a extensão e a distribuição do sistema radicular é essencial à citricultura, pela sua importância na nutrição e absorção de água e porque as raízes são diretamente afetadas por tratos culturais, adubação e irrigação. Segundo esses autores, produzir bem significa manejar bem o sistema radicular. Afirmaram, entretanto, que esta importância nem sempre é reconhecida.

As raizes das plantas cítricas têm a distribuição variável com as características químicas e fisicas do solo, os tratos culturais, o tipo de copa e de porta-enxerto, a idade da planta e suas condições fitossanitárias. Têm sido estudadas por diversos pesquisadores das regiões produtoras do mundo todo, sob vários aspectos, mas poucos são os trabalhos que se dedicaram a explorar a distribuição radicular sob a influência de sistemas de manejo de solo. A maioria dos trabalhos sobre o sistema radicular dos citros tem sido feita para comparar espécies e variedades de porta-enxertos.

Ford (1953), na Flórida, utilizou o método do trado e determinou a profundidade do sistema radicular de plantas de laranja 'Valência' com 29 anos de idade 
e verificou que as plantas apresentavam cerca de $60 \%$ de suas raízes a até $0,75 \mathrm{~m}$ de profundidade e cerca de $90 \%$ a $1,5 \mathrm{~m}$ de profundidade, em solo ácido, arenoso e profundo. O mesmo autor (Ford, 1954) estudou o sistema radicular de porta-enxertos no mesmo solo de plantas com 10-15 anos de idade e obteve distribuições semelhantes ao trabalho anterior. $\mathrm{O}$ autor observou que o sistema radicular apresenta a tendência de se aprofundar com a idade das plantas, ocorrendo com o tempo uma mudança da zona de maior concentração de raízes.

No Brasil, Montenegro (1960) avaliou, com o método do trado, o sistema radicular de oito porta-enxertos sob copa de laranjeira 'Pêra', 'Hamlin' e 'Baianinha', no Estado de São Paulo. De maneira geral, para todas as combinações de copa e portaenxerto, cerca de $90 \%$ das raízes com diâmetro menor ou igual a $1,5 \mathrm{~mm}$ encontravamse nos primeiros $60 \mathrm{~cm}$ do solo. Esse autor observou também que a maior quantidade de raízes de uma planta nem sempre corresponde à maior copa ou à maior produção de frutos.

Moreira (1983a) em São Paulo, pelo método do trado, avaliou a influência de dez herbicidas e de capina na linha de plantio de laranjeira 'Pêra' enxertada sobre limoeiro 'Cravo' com sete anos de idade. Na entrelinha todos os tratamentos tiveram as ervas daninhas controladas através de gradeação. Esse autor não observou diferenças entre os tratamentos, que indicaram, de maneira geral, uma concentração de cerca de 50 $\%$ de radicelas até $15 \mathrm{~cm}$ de profundidade e $60 \%$ até $30 \mathrm{~cm}$, distribuídas uniformemente pelo terreno, em transição latossolo vermelho amarelo e latossolo roxo.

Martinez et al. (1970) conduziram um experimento de práticas de manejo do solo em pomar de laranjeira 'Hamlin' enxertada sobre laranjeira 'Caipira'. Os tratamentos foram: solo permanentemente limpo com grade de discos, herbicidas, mucuna preta na época chuvosa, cobertura morta permanente, mato natural ceifado nas águas e gradeado na seca, soja-perene, aração superficial e mato natural ceifado. Os autores concluíram que não houve diferenças significativas entre os tratamentos para a distribuição do sistema radicular. 
Pace \& Araujo (1986) estudaram no Rio de Janeiro, pelo método da trincheira, a distribuição das raízes (com diâmetro menor ou igual a $1,5 \mathrm{~mm}$ ) de três porta-enxertos, em solo podsolizado. As plantas tinham como copa laranja 'Natal'. Houve uma redução abrupta do percentual de radicelas abaixo dos $20 \mathrm{~cm}$ de profundidade, local da mudança textural entre os horizontes A e B, com a quantidade de argila aumentando de 15-20\% para $48 \%$, e a densidade do solo alterando de 1,29-1,35 para $1,44 \mathrm{~kg} \mathrm{dm}^{-3}$. Esses autores observaram também uma grande diferença entre os porta-enxertos quanto à distancia máxima que as raízes atingiram a partir do tronco. Poncirus trifoliata e limão 'Cravo' ficaram a 2,10 e 2,50 m, respectivamente, enquanto o limão 'Volkameriano' teve suas raízes distribuídas até $3,90 \mathrm{~m}$ a partir do tronco.

Oliveira (1991), em observações feitas em Matão-SP, verificou que o sistema radicular dos citros foi mais denso e profundo e a produção foi maior em laranjeiras situadas em solo eutrófico, quando comparadas com as desenvolvidas em solos com elevada saturação por alumínio.

Segundo Mazza et al. (1994), na cultura dos citros deve-se procurar sempre - possibilitar um maior aprofundamento do sistema radicular, para promover, por um maior período do ano, a absorção mais freqüente de água e nutrientes do solo pelas plantas. Esses autores observaram que a compactação do solo, com redução da macroporosidade de $32 \%$ para $10 \%$, provocou uma redução no sistema radicular, avaliado qualitativamente em trincheiras.

Frith (1952), na Austrália, observou o sistema radicular dos citros em um experimento fatorial com quatro tipos de manejo do solo, quatro níveis de adubação nitrogenada, quatro níveis de irrigação e quatro combinações enxerto/porta-enxerto. Os tipos de manejo testados foram: cultivo mecânico no verão e adubo verde no inverno, o mesmo tratamento mais esterco de curral, vegetação natural ceifada, e herbicida (querosene). As plantas submetidas aos tratamentos de ceifa tiveram quantidade significativamente maior de raízes nos primeiros $10 \mathrm{~cm}$ do solo, mas não houve diferenças para as demais profundidades e nem para o perfil como um todo. Apesar dessa maior 
quantidade de raízes, este tratamento não foi o que proporcionou a maior produção, ficando esta colocação com o tratamento herbicida.

$\mathrm{Na}$ Venezuela, Avilan et al. $(1979 ; 1986)$ observaram, em pomares comerciais, o sistema radicular de plantas cítricas sobre diversos porta-enxertos e tipos de solos, com produtividades variadas. As plantas menos produtivas situavam-se em solo com drenagem deficiente, sendo que $80 \%$ das raízes situavam-se nos primeiros $30 \mathrm{~cm}$ do solo.

Sánchez et al. (1988), em um levantamento das condições de pomares cítricos venezuelanos situados em solos rasos ou com horizonte B textural, encontraram alta correlação entre o desenvolvimento da copa e a quantidade de raízes a 60-90 cm de profundidade e destas com os atributos do solo relacionados com o fluxo de água e ar (porosidade, densidade do solo, difusão de oxigênio, presença de fendas e teor de argila).

Tucker et al. (1980) avaliaram durante dez anos o uso de herbicidas (bromacil e diuron) e cultivo mecânico em pomares comerciais de diversas variedades de laranjas na Flórida. Na profundidade de $0-15 \mathrm{~cm}$ ocorreu a presença do dobro de raízes no tratamento de herbicida, em relação ao cultivo mecânico. Esta diferença, entretanto, não foi observada para a profundidade de $15-30 \mathrm{~cm}$.

\subsection{Manejo do solo em pomares cítricos e sua influência nas características físicas e químicas do solo}

O solo é o componente do sistema produtivo que recebe os efeitos das práticas de manejo de maneira direta. Entretanto, os trabalhos realizados para estudar manejo de solo em pomares muitas vezes analisam apenas o aspecto da produtividade das plantas, sendo os resultados disponíveis sobre solo em menor quantidade.

No Rio Grande do Sul, Koller et al. (1977) estudaram o comportamento de um pomar de laranjas 'Valência' e 'Baianinha' com o solo mantido sem vegetação durante a primavera e o verão, mediante uma aração e três gradagens ao ano, ou mantido com vegetação nativa, ceifada periodicamente. $O$ sistema de manter o solo coberto com 
vegetação nativa manteve mais elevados o teor de matéria orgânica do solo até a profundidade de $45 \mathrm{~cm}$, o teor de potássio até $15 \mathrm{~cm}$, o teor de fósforo nas profundidades de 15 a $45 \mathrm{~cm}$, e o $\mathrm{pH}$ até $30 \mathrm{~cm}$ de profundidade.

Cintra et al. (1983), na Bahia, realizaram um experimento de manejo de solo em pomar de laranja 'Baianinha' com os seguintes tratamentos: herbicida diuron, diuron mais bromacil, gradagem no verão e ceifa no inverno, gradagem permanente, e ceifa permanente. As determinações fisicas constaram de densidade do solo e de partículas, agregação, granulometria, taxa de infiltração de água e resistência à penetração. $\mathrm{O}$ tratamento com ceifa permanente permitiu a manutenção das características fisicas do solo e melhoria da estrutura, graças ao incremento no teor de matéria orgânica. A gradagem permanente promoveu redução no tamanho dos agregados e na porcentagem de agregação, além de formar uma camada compactada de $10-15 \mathrm{~cm}$. O uso de herbicida causou a formação de crostas superficiais, reduzindo a velocidade de infiltração de água. Os autores concluíram que, considerando a ocorrência de um período de elevado déficit hídrico na região, a prática de gradagem nesta época, associada com ceifa no período das chuvas, pode minimizar a competição com a vegetação natural pela água.

Cintra \& Coelho (1987) estudaram as características fisicas de três pomares comerciais de citros na Bahia, em latossolo amarelo distrófico. Os pomares se caracterizavam pela permanência do solo a descoberto através de gradagens ou de capina manual. As determinações foram de retenção de água, densidade do solo e de partículas, agregação, e matéria orgânica do solo. Os resultados demonstraram que, em face da alta porcentagem de areia dos solos e do déficit hídrico que ocorre na região torna-se indispensável, para a obtenção de produtividades adequadas, a adoção de práticas culturais que permitam aumentar o teor de matéria orgânica e a capacidade de retenção de água dos solos.

Godefroy \& Bourdeaut (1972) observaram as alterações provocadas em um oxisolo da Costa do Marfim em um pomar cítrico submetido à vegetação natural por dez anos, vegetação natural por dez anos seguida de cobertura de Stylosanhtes gracilis por três anos, e cobertura de Pueraria javanica durante dez anos. Os teores de nitrogênio, 
cálcio e soma de bases do solo do pomar foram mais elevados com vegetação natural e $S$. gracilis do que em $P$. javanica, com maiores. Esses autores avaliaram também a estrutura do solo, através do índice de estabilidade estrutural, que foi significativamente mais elevado nos tratamentos $S$. gracilis e $P$. javanica do que na vegetação natural, mas o teor de matéria orgânica não apresentou diferenças significativas entre os tratamentos.

Menegucci et al. (1995) avaliaram as condições do solo de um pomar cítrico em Ijaci (MG) com e sem a presença de Crotalaria juncea, cultivada por uma safra. Na profundidade $0-20 \mathrm{~cm}$ o efeito mais marcante da adubação verde foi a elevação do teor de matéria orgânica de 4,4\% nas parcelas sem crotalária para 5,1\% nas parcelas que receberam a leguminosa. Para os demais atributos do solo as maiores diferenças foram observadas na camada $20-40 \mathrm{~cm}$, tendo a adubação verde provocado aumento de $\mathrm{pH}$, cálcio, magnésio e soma de bases.

Tucker et al. (1980) observaram um aumento de $100 \%$ no teor de matéria orgânica do solo em pomares comerciais de laranjas na Flórida manejados com cultivo mecânico, quando comparados ao uso de herbicidas (bromacil e diuron) durante dez anos.

Silva (1995) utilizou, durante a formação do pomar (quatro anos), tratamentos com espécies de leguminosas nas entrelinhas do pomar mais adubação com $\mathrm{P}$ e $\mathrm{K}$, sem adubo verde com NPK e sem adubo verde com 2NPK. Esse autor não constatou diferenças entre os tratamentos para as características químicas do solo.

\subsection{Fracionamento granulométrico da matéria orgânica do solo}

A qualidade do solo pode ser definida como a habilidade de um tipo específico de solo de funcionar, dentro de um ecossistema natural ou manejado, de modo a sustentar a produtividade animal e vegetal, manter ou melhorar a qualidade da água e do ar, e permitir a habitação e saúde humanas, de acordo com Karlen et al. (1997). Estes autores salientaram a importância da determinação de parâmetros que possam ser utilizados para avaliar a qualidade dos solos e apontaram diversos atributos como 
indicadores, dentre eles a matéria orgânica do solo e a agregação. Da mesma forma, Feller (1995) citou a matéria orgânica do solo como um dos indicadores potenciais da durabilidade dos sistemas agrícolas, podendo ser usada isoladamente ou como componente de um modelo mais complexo.

Esta importância se deve aos papéis exercidos pela matéria orgânica do solo na manutenção da fertilidade, agindo como agente cimentante na formação dos agregados, reduzindo os riscos de erosão, aumentando a capacidade de troca de cátions, sobretudo nos solos intemperizados das regiões tropiciais, e como fonte de nutrientes para as plantas (Sánchez, 1981). Além disso, a quantidade de matéria orgânica do solo pode indicar a adequação do manejo do solo utilizado, pois seu teor em ecossistemas naturais mantém-se relativamente estável, havendo um equilíbrio entre as adições e as perdas. Com a introdução de práticas agrícolas, a quantidade de matéria crgânica do solo tende a diminuir, pois a adição geralmente é reduzida e as perdas se intensificam com o maior revolvimento e aeração do solo, estabelecendo-se um novo equilíbrio, com teores de matéria orgânica geralmente inferiores aos do sistema natural.

Existe uma estreita relação entre a matéria orgânica do solo e as partículas dos minerais de argila, formando complexos organominerais (Schinitzer,1986). Solos com maior conteúdo de argila tem maior poder de conservação e estabilização da matéria orgânica (Feller, 1995; Lepsch et al., 1982). Porém, devido à complexidade da associação organomineral, o estudo desses componentes tem sido feito de forma dissociada. A matéria orgânica do solo tem sido analisada de acordo com um enfoque bioquímico, procurando-se minimizar o conteúdo de cinzas, enquanto que o estudo dos minerais é feito depois da eliminação da matéria orgânica (Christensen, 1992).

$\mathrm{O}$ fracionamento físico do solo, de acordo com o tamanho das partículas, tem se mostrado uma ferramenta útil no estudo da matéria orgânica do solo. Esta metodologia não causa a desestruturação da matéria orgânica, pois separa o componentes ainda não decompostos, e permite estudar as associações organo-minerais, bem como o balanço de nutrientes como carbono, nitrogênio, fósforo e enxofre nos vários tamanhos de partículas e as alterações nestes balanços provocadas pelo cultivo e manejo do solo, 
revelando diferenças tanto na estrutura como nas propriedades dinâmicas da matéria orgânica quando ligada às partículas de vários tamanhos. Pela possibilidade de localização dos componentes orgânicos de acordo com o tamanho das partículas do solo, é possível estudar também, com maior detalhe, o papel da matéria orgânica na microagregação do solo. Estudos de fracionamento químico subsequentes ao fracionamento granulométrico podem ser feitos e darão informações mais precisas sobre o tipo de componente orgânico que está associado a cada uma das frações determinadas.

Muitos trabalhos têm demonstrado que quando o teor total de carbono do solo muda, as concentrações em carbono das partículas de vários tamanhos são afetadas de forma diversa, indicando que a matéria orgânica do solo tem diferentes períodos de "turnover", dependendo do tipo de partícula à qual ela se liga (Dalal \& Mayer, 1986; Christensen, 1987; Feller, 1988).

Estudos realizados por Feller (1995), ao microscópio ótico nas frações 'granulométricas da matéria orgânica do solo, permitiram observar que: as frações 200$2.000 \mu \mathrm{m}$ e $50-200 \mu \mathrm{m}$ são formadas essencialmente por resíduos vegetais de folhas e raízes com estrutura mais ou menos reconhecível, associados a resíduos orgânicos aparentemente mais humificados e de aspecto semelhante a carvão. Estes últimos aparecem mais na fração 50-200 do que 200-2.000 $\mu \mathrm{m}$. A fração silto-argilosa $(<50 \mu \mathrm{m})$ a essa escala de observação não parece ter elementos figurados reconhecíveis, com exceção de resíduos orgânicos semelhantes ao carvão já mencionado. Ao microscópio eletrônico de transmissão as observações foram as seguintes: as frações 20-2.000 $\mu \mathrm{m}$ são dominadas por material orgânico discernivel, de origem vegetal, sendo que os de menor tamanho são menos estruturados. Podem estar partidos pela ação de fungos. Na fração 20-50 $\mu \mathrm{m}$ coexistem fragmentos de tecidos vegetais e fúngicos pouco ligados a partículas minerais e microagregados constituídos de paredes celulares associadas a minerais (quartzo, filitos ou óxidos de ferro). A fração 2-20 $\mu \mathrm{m}$ é constituída de microagregados (1-5 $\mu \mathrm{m})$ formados essencialmente por empilhamento de filitos e paredes vegetais ou micélios decompostos. A fração 0-2 $\mu \mathrm{m}$ é dominada por constituintes minerais (filitos e 
óxidos de ferro) mas há também a presença de restos de paredes vegetais, bactérias mais ou menos desestruturadas e material orgânico não discernivel (amorfo).

Anderson et al. (1981) analisaram dois molissois do Canadá e observaram que 55 e $58 \%$ do carbono orgânico e 61 e $68 \%$ do nitrogênio orgânico encontravam-se na fração argila, com maior proporção na argila grossa $(0,2-2 \mu \mathrm{m})$ do que na argila fina (< $0,2 \mu \mathrm{m})$. Esses autores encontraram cerca de $70 \%$ do $S$ orgânico também nestas duas frações, porém com maior proporção na fração argila fina.

Adams (1982) avaliou as diferenças entre a distribuição de carbono e nitrogênio nas frações de dois solos da Irlanda do Norte quando submetidos à pastagem natural, pastagem mais esterco líquido de porco ou gado, ou sob cultivo contínuo por um, dois, nove e 33 anos. De maneira geral, as frações de menor tamanho $(0,03-0,2 \mu \mathrm{m}$ ) possuíam as maiores proporções do carbono e nitrogênio totais. $\mathrm{O}$ solo sob pastagem natural apresentou maior concentração de carbono em todas as frações (sobretudo na fração $<20 \mu \mathrm{m}$ ) e esta diferença foi acentuada com o aumento do tempo de cultivo. $\mathrm{O}$ esterco bovino aumentou o carbono em todas as frações, sobretudo na fração areia (20 $2.000 \mu \mathrm{m})$ e coloidal $(<0,03 \mu \mathrm{m})$, enquanto que o esterco suíno aumentou o carbono apenas na fração argila $(0,03-2 \mu \mathrm{m})$.

Bruckert \& Kilbertus (1980) realizaram o fracionamento fisico da matéria orgânica de dois solos de clima temperado, um bruno de uma região fria e úmida e um chernozem de região fria e seca. Na superficie, para os dois solos, a fração menor que 50 $\mu \mathrm{m}$ representou $56-57 \%$ do carbono total, enquanto que a $80-130 \mathrm{~cm}$ de profundidade, esta fração representou 83 a 99 \%. Considerando as mesmas profundidades, a fração 50$100 \mu \mathrm{m}$ representou respectivamente $30 \%$ e $1 \%$ e a fração $100-2.000 \mu \mathrm{m}$ representou 23 $\%$ e $0 \%$ do carbono total do solo. A relação $\mathrm{C} / \mathrm{N}$ foi, para as três frações respectivamente, de 11-15, 13-16 e 19-27.

Dalal \& Mayer (1986) estudaram o teor de matéria orgânica das partículas de vários tamanhos de seis solos da Austrália, com diversas texturas, em estado virgem e submetidos a cultivo durante 20 a 70 anos. Para todos os solos virgens a quantidade de matéria orgânica da fração argila situou-se em torno de 48 \% e para as frações silte e 
areia ficou em $26 \%$. Com o cultivo de cereais, o teor de matéria orgânica de todas as frações diminuiu com o período de cultivo, sendo maiores as perdas na fração areia para todos os solos. Em conseqüência, a proporção do carbono orgânico da fração argila foi aumentada com o tempo de cultivo em relação ao estado inicial. A perda do material orgânico das partículas da fração areia deve-se principalmente ao fato de que o material orgânico desta fração é composto principalmente por resíduos vegetais ainda não decompostos e hifas de fungos, e portanto, mais suscetíveis à oxidação e à desintegração pelo cultivo. A perda da matéria orgânica das frações argila e silte deve-se provavelmente às perdas de massa microbiana e seus resíduos. Esses autores denominam esta matéria orgânica de livre ou lábil, isto é, a matéria orgânica da porção areia mais a porção não intimamente associada às frações argila e silte, que é rapidamente perdida com o cultivo do solo. A matéria orgânica intimamente associada às partículas de argila encontra-se mais protegida de ataques microbianos e enzimáticos.

Leinweber \& Reuter (1992), na Alemanha, avaliaram o solo de um experimento de longa duração de adubação orgânica e mineral realizado em vasos, a fim de observarem as alterações das concentrações de carbono e nitrogênio orgânicos durante a formação das partículas organominerais de um solo franco, inicialmente sem matéria orgânica, cultivado com gramíneas durante 34 anos. Os tratamentos foram adubação mineral, palha mais adubo mineral, esterco e composto, em quantidades equivalentes de matéria seca, até o $19^{\circ}$ ano, a partir do qual usou-se adubo químico. Para quase todos os anos e frações os teores de carbono e nitrogênio dos tratamentos foram na seguinte ordem: composto $>$ esterco $>$ palha mais adubo mineral $>$ adubo mineral. As menores frações apresentaram maior concentração de carbono e nitrogênio na seguinte ordem: argila ( $<2 \mu \mathrm{m})$, silte médio $(6,3-20 \mu \mathrm{m})$, silte fino $(2-6,3 \mu \mathrm{m})$, silte grosso (20 $63 \mu \mathrm{m})$ e areia $(63-200 \mu \mathrm{m})$. 0 teor de carbono das partículas de argila aumentou durante todo o período do trabalho, mas o de silte fino aumentou apenas nos tratamentos de adubos orgânicos, exceto para o composto, em que ocorreu um decréscimo do $19^{\circ}$ ao $34^{\circ}$ ano. Nas frações silte grosso e areia observaram-se alguns acréscimos contínuos, mas de maneira geral o pico da concentração de carbono orgânico foi no $13^{\circ}$ ano. Para o 
não foi observado acréscimo na fração argila entre o $13^{\circ}$ e $19^{\circ}$ anos para os tratamentos adubo mineral, palha mais adubo mineral e esterco, mas depois da substituição da adubação orgânica pela química, houve um aumento de nitrogênio em 35 - 60 \%. Nas frações silte médio e fino o nitrogênio aumentou ao longo do tempo. Ocorreram redistribuições, principalmente depois que o adubo orgânico foi suspenso. Esta fase foi caracterizada pelo decréscimo de carbono e nitrogênio orgânicos totais, mas com acréscimos na fração argila, em detrimento da fração areia, indicando um "turn-over" mais rápido da fração areia.

Feller et al. (1983) estudaram o efeito da incorporação de palha na matéria orgânica das frações granulométricas de um solo arenoso do Senegal. As frações determinadas foram: FO maior que $2.000 \mu \mathrm{m}$ (orgânica), FM maior que 2.000 um

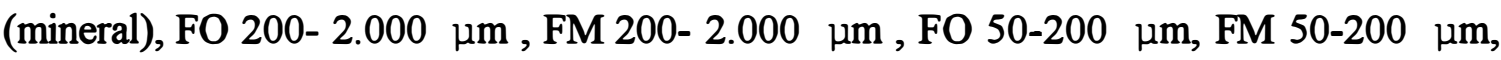
FOM menor que $50 \mu \mathrm{m}$ (organomineral). A fração menor que $50 \mu \mathrm{m}$ foi responsável pela maior parte do carbono $(51,4 \%)$ e do nitrogênio $(62,2 \%)$ totais do solo, seguida da fração 50-200 $\mu \mathrm{m}$, com $31.6 \%$ do carbono e $23.9 \%$ do nitrogênio. Com a adição da palha ocorreu um aumento médio de $30 \%$ para os teores totais dos dois elementos, mas este incremento não foi uniforme entre as frações. A fração FOM menor que $50 \mu \mathrm{m}$ teve uma variação praticamente nula enquanto que as frações 50-200 e 200-2.000 foram as principais responsáveis pelo aumento da matéria orgânica do solo. A relação $\mathrm{C} / \mathrm{N}$ foi pouco afetada pela adição da palha, com valores de 7,$2 ; 11,5 ; 15,7 ; 28,0$ para as frações menor que 50, 50-200, 200-2.000 e maior que $2.000 \mu \mathrm{m}$, respectivamente.

Feller (1988) avaliou a influência de sistemas de uso da terra (pastagem, pousio, culturas hortícolas, rotação de culturas) por sete a dez anos no estoque orgânico nas frações de solos das Antilhas. As frações analisadas foram 0-5 $\mu \mathrm{m}$ (complexo organomineral argiloso), 5-25 e 25-50 um (complexo organo mineral + resíduos vegetais + agregados organo minerais + silte), 50-200 $\mu \mathrm{m}$ (resíduos vegetais + areia fina), maior que $200 \mu \mathrm{m}$ (resíduos vegetais + areia grossa). A relação $\mathrm{C} / \mathrm{N}$ destas frações foram, respectivamente: $8-10,5 ; 12-15 ; 13-16 ; 14-20$, e 18-28. O teor de carbono das frações 05, 5-50 e maior que 50 um foi: 55-62\%, 14-17\% e 16-24\% do carbono total do solo, 
respectivamente. Para os sistemas de cultura observou-se que a maior variação entre os valores de carbono orgânico ocorreram nas frações 0-5 e maior que $50 \mu \mathrm{m}$. As frações organo-siltosas sofreram pouca influência do sistema de cultivo, indicando que as maiores transformações (perdas) ocorreram nos resíduos vegetais (maior que $50 \mu \mathrm{m}$ ) e nas exudações microbianas e radiculares $(0-5 \mu \mathrm{m})$.

Esta maior resistência às transformações da fração silte da matéria orgânica foi também observada por Christensen (1987), que estudou a taxa de decomposição da matéria orgânica associada às diversas partículas de um solo arenoso e de um franco arenoso da Dinamarca, com incorporação ou queima de palha. As partículas analisadas foram argila (menor que $2 \mu \mathrm{m})$, silte $(2-20 \mu \mathrm{m})$ e areia $(20-6.000 \mu \mathrm{m})$. A maior parte do carbono e nitrogênio do solo estava na fração argila (50-65 \% para o C e 56-68 \% para o nitrogênio). A fração silte teve proporções um pouco menores (29-41 \% para o carbono e 27-38 \% para o nitrogênio) e a fração areia teve $4-7 \%$ de. $O$ solo total e as partículas separadas foram incubados durante 49 dias, sendo monitorada a liberação de $\mathrm{CO}_{2}$ periodicamente, a fim de determinar a taxa de decomposição da matéria orgânica, que foi mais alta no solo areno siltoso do que no arenoso. Para as frações de ambos os solos as taxas de decomposição diferiram na seguinte ordem: areia $>$ argila $\geq$ solo total $>$ silte. A incorporação de palha aumentou em pequena quantidade o teor de carbono em todas as frações.

Tiessen \& Stewart (1983) analisaram dois molissois e um entissol do Canadá solos com diferentes texturas, sob pastagem natural ou cultivo durante quatro a 90 anos. Em condição de campo nativo, as frações silte fino $(2-5 \mu \mathrm{m})$ e argila grossa $(0,2-2$ $\mu \mathrm{m})$ foram as que apresentaram a maior quantidade de carbono (por grama de fração). A relação $\mathrm{C} / \mathrm{N}$ foi de 15 na fração areia (maior que $50 \mu \mathrm{m}$ ) e 7 na fração argila fina ( 0- 0,2 $\mu \mathrm{m})$. $\mathrm{O}$ solo mais argiloso teve maior proporção de carbono na fração argila grossa. Com o cultivo durante quatro anos não houve redução de carbono total, mas para 60 anos houve uma redução de aproximadamente $50 \%$ do carbono total do solo. Esta redução não foi uniforme entre as frações. As maiores reduções ocorreram na fração areia e na fração argila fina, que possuem material orgânico lábil, de origem recente (vegetal e 
microbiano). Menores perdas ocorreram nas frações silte fino e argila grossa, principalmente por mineralização. As perdas do carbono total foram importantes até 60 anos de cultivo, sendo pequenas entre 60 e 90 anos, tendo o sistema aparentemente atingido um novo equilíbrio após os 60 anos.

Christensen (1988) avaliou o efeito da adição de esterco e adubação mineral, em uma rotação de culturas na Dinamarca durante 90 anos, no teor de carbono e nitrogênio do solo total e das partículas de argila (menor que $2 \mu \mathrm{m})$, silte $(2-20 \mu \mathrm{m})$, areia fina $1(20-63 \mu \mathrm{m})$, areia fina $2(63-200 \mu \mathrm{m})$ e areia grossa $(200-2.000 \mu \mathrm{m})$ de um solo franco-arenoso. Os teores foram comparados com parcelas que não receberam adubação e com parcelas que tiveram adubação mineral com quantidades equivalentes de nitrogênio nos últimos 60 anos. $O$ teor de carbono do solo total aumentou de $1,19 \%$ no solo sem adubação, para 1,36 com adubação química e para $1,54 \%$ com adubação orgânica. $O$ teor de nitrogênio no solo total aumentou de 0,094 \% sem adubação para $0,116 \%$ com adubação química e para 0,134 \% com adubação orgânica. As partículas que mais tiveram os teores aumentados foram argila e silte, enquanto que as demais foram pouco afetadas. A adubação orgânica aumentou o teor de carbono das frações silte e argila em $36 \%$ enquanto que a adubação mineral aumentou o teor de carbono da fração silte em $21 \%$ e da fração argila em $14 \%$. A porção argila teve $58 \%$ e $65 \%$ do total de carbono e nitrogênio do solo, e a porção silte teve $30 \%$ e $26 \%$, respectivamente. Estes padrões não foram afetados pelas adubações. A relação $\mathrm{C}: \mathrm{N}$ das frações silte e argila e do solo total foram, respectivamente, 14,$3 ; 10,6$ e 12,0 .

Feller (1993) avaliou a influência do clima e da textura do solo no estoque e a dinâmica da matéria orgânica do solo em oxissois da África, Antilhas e Brasil. Esse autor constatou que o estoque de carbono do solo foi muito mais determinado pelo teor de argila mais silte do que pelo clima, mesmo considerando o grande gradiente estudado (600 a $3.000 \mathrm{~mm}^{2}$ ano $^{-1}$ de chuva). Comparando o teor total de carbono do solo das várias situações estudadas, constatou-se uma redução de 30 a $40 \%$ quando o solo foi submetido ao cultivo, comparando-se com o solo não cultivado. Esta redução deu-se em três anos para os solos arenosos e em dez anos para os argilo-arenosos. Quanto aos 
teores de carbono das frações, levando-se em consideração a textura do solo, observouse que para as frações $20-2.000 \mu \mathrm{m}$ os teores foram praticamente constantes $(3 \mathrm{a} 5 \mathrm{mg} \mathrm{C}$ $\mathrm{g}^{-1}$ solo) quaisquer que fossem os teores de argila. Para as frações 2-20 $\mu \mathrm{m}$ os teores aumentaram com o teor de argila ( 3 a $8 \mathrm{mg} \mathrm{C} \mathrm{g}^{-1}$ solo), sendo este aumento ainda maior

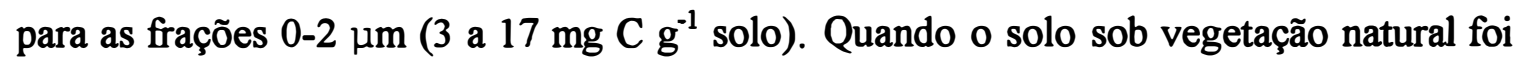
submetido ao cultivo as mudanças no estoque de carbono dependeram da textura do solo: para os arenosos a redução mais importante ocorreu na fração de resíduos vegetais (20$2.000 \mu \mathrm{m}$ ) enquanto que para solos siltosos a redução foi devida principalmente às frações silte $(2-20 \mu \mathrm{m})$ e para os argilosos a redução do carbono ocorreu principalmente na fração argilosa, seguida da fração resíduo vegetal e depois silte. Quando o solo cultivado foi deixado em pousio, o aumento do carbono ocorreu também de forma diferenciada de acordo com a textura do solo: os aumentos totais foram maiores para os solos argilosos. Quanto ao aumento por fração, constatou-se para os solos arenosos uma maior contribuição da fração resíduo vegetal e secundariamente da fração silte (2-20 $\mu \mathrm{m})$ com pouca contribuição da fração argilosa). Para os solos areno-argilosos houve uma contribuição eqüitativa de todas as frações e para os solos argilosos o aumento foi prioritariamente devido à fração argilosa, seguida de resíduos vegetais, havendo pouca contribuição da fração silte.

Schulten \& Leinweber (1991) analisaram a matéria orgânica do solo cultivado com centeio por 100 anos com e sem a adição de esterco (12 $\mathrm{Mg} \mathrm{ha}^{-1}$ ano $\left.^{-1}\right)$ em um chernozem, de textura areia franca. O fracionamento foi efetuado de acordo com os seguintes tamanhos de partículas: areia $(63-2.000 \mu \mathrm{m})$, silte grosso $(20-63 \mu \mathrm{m})$, silte médio $(6,3-20 \mu \mathrm{m})$, silte fino $(2-6,3 \mu \mathrm{m})$, argila grossa $(0,63-2 \mu \mathrm{m})$, argila média + fina $(<0,63 \mu \mathrm{m})$. Em ambos os tratamentos (com e sem esterco) as concentrações de carbono e nitrogênio foram mais altas nas frações silte fino, mas em todas as frações o uso de esterco aumentou a concentração dos dois elementos. $O$ aumento da porcentagem de carbono e nitrogênio em relação ao total do solo foi maior nas frações silte médio e silte fino, enquanto que as frações argila tiveram redução da porcentagem do carbono total com o uso do esterco. 
Feigl et al. (1995) analisaram as mudanças ocorridas à matéria orgânica de um solo podzólico vermelho amarelo de Rondônia, depois do desmatamento e da introdução de pastagem por 2 - 80 anos. Esses autores observaram que a introdução da pastagem provocou um ligeiro aumento no teor de carbono total do solo em todas as frações avaliadas, quando comparadas com a floresta. 
3 MANEJO DE SOLO EM POMAR DE TANGERINA 'PONCÃ' EM LONDRINA, PR E SUA INFLUÊNCIA NO ESTADO NUTRICIONAL DAS PLANTAS, PRODUÇÃO, QUALIDADE DOS FRUTOS E CARACTERÍSTICAS QUÍMICAS DO SOLO 


\section{MANEJO DE SOLO EM POMAR DE TANGERINA 'PONCÃ' EM LONDRINA, PR E SUA INFLUÊNCIA NO ESTADO NUTRICIONAL DAS PLANTAS, PRODUÇÃO, QUALIDADE DOS FRUTOS E CARACTERÍSTICAS QUÍMICAS DO SOLO}

\subsection{Resumo}

Em um pomar de tangerina 'Poncã' em latossolo roxo, em Londrina-PR, foram testados cinco tratamentos de manejo do solo: cobertura verde durante todo o ano com a leguminosa perene Indigofera campestris Benth.; cobertura verde durante todo o ano com a leguminosa perene Arachis prostrata Bong. ex Benth.; cobertura durante a época de chuvas com mucuna cinza - Stizolobium pruriens (leguminosa anual); uso alternado de uma gradagem a disco (no período seco) e de roçadeira (no período de chuvas); capina manual o ano inteiro. Os tratamentos permaneceram no campo durante nove anos. A produção, a qualidade dos frutos e a nutrição das plantas não foram significativamente afetadas pelos tratamentos. $\mathrm{O}$ teor de matéria orgânica do solo foi aumentado pelos tratamentos $A$. prostrata e gradagem/ roçadeira. Os demais atributos químicos analisados não apresentaram diferenças entre os tratamentos.

3.2 Summary: EFFECT OF ORCHARD SOIL MANAGEMENT ON LEAF NUTRIENT CONTENT, YIELD, FRUIT QUALITY OF "PONCÃ" TANGERINE AND SOIL CHEMICAL CHARACTERISTICS IN LONDRINA, PR 
A trial with 'Poncã' tangerine (Citrus reticulata Blanco) on 'Rangpur Lime' rootstock was carried out in Londrina-PR on an oxisol to study the effect of orchard floor management on plant yield, nutrition, fruit quality and soil chemical characteristics. Five treatments were used: permanent soil cover with Indigofera campestris Benth; permanent soil cover with Arachis prostrata Bong. ex Benth; 'mucuna cinza' (Stizolobium pruriens) during spring and summer; alternate mowing (rainy season) /tillage (dry season); and vegetation-free (by hand hoeing). After nine years, yield, fruit quality and plant nutrition were not affected by treatments. Soil organic matter was increased by $A$. prostrata and by alternate mowing / tillage. Other soil chemical characteristics were not affected by the treatments.

\subsection{Introdução}

O sistema de manejo do solo do pomar pode influenciar o desenvolvimento, a sanidade e a produtividade da cultura, bem como as condições físicas, químicas, biológicas do solo e sua conservação. As regiões do norte e noroeste do Estado do Paraná, onde a citricultura tem se estabelecido, possuem clima tropical e subtropical, caracterizando-se por maior ocorrência de chuvas durante a primavera e verão (outubro a março). Por este motivo é importante manter o solo protegido durante este período, reduzindo os riscos de erosão (Rufino et al., 1992). No Estado de São Paulo, segundo Negri (1988), o sistema de cultivo recomendado nos pomares cítricos é o uso de roçadeira três a quatro vezes nas entrelinhas, durante o período chuvoso, e uma gradeação no período seco, sendo que nas linhas de plantio é feita uma capina com enxada ou herbicida. Muitos citricultores, porém, intensificam o uso da grade de disco na entrelinha de plantio (Victoria Filho, 1988), ocasionando problemas como danos ao sistema radicular, compactação, redução da taxa de infiltração de água, aumento dos riscos de erosão e de problemas fitossanitários. Por essas razões, tem-se testado o uso de adubos verdes ou sistemas mistos, em que as leguminosas são semeadas em entrelinhas alternadas, para facilitar a circulação no pomar (Demattê \& Vitti, 1992; Vitti \& Silva, 
1996). O emprego de leguminosas como cobertura do solo apresenta os beneficios de proteger o solo contra a erosão, evitar a infestação de ervas daninhas, descompactar o solo (dependendo da espécie usada) e de fixar o nitrogênio atmosférico, auxiliando na nutrição das plantas cítricas. De acordo com Castro \& Lombardi Neto (1992), não se tem observado redução na produção de frutas a longo prazo com o uso de adubos verdes nos pomares cítricos, chegando, em alguns casos, a ocorrer um aumento nessa produção. No Estado do Paraná, várias espécies de leguminosas de ciclo temporário ou permanente têm sido recomendadas para cobertura do solo em pomares, entre as quais encontram-se a mucuna cinza, o amendoim rasteiro e a indigofera (Calegari, 1995).

Diversos trabalhos tem sido conduzidos no Brasil para estudar o comportamento dos pomares cítricos submetidos a sistemas de manejo do solo. Os resultados têm indicado que, de maneira geral, o sistema mais prejudicial à produção de frutos é o de vegetação natural ceifada durante todo o ano, como foi observado por Rodriguez (1969) com laranja 'Hamlin' enxertada sobre laranja 'Caipira' em São Paulo, Dornelles (1971) com seis cultivares de laranjeira, no Rio Grande do Sul, Passos et al. (1973) com laranja ‘Baianinha' sobre limão ‘Cravo' na Bahia, Pacheco et al. (1973), com laranja 'Baianinha' sobre limão 'Cravo' em Minas Gerais, e Koller et al. (1977), com laranjas 'Valência' e 'Baianinha' sobre laranja 'Caipira', no Rio Grande do Sul. Por outro lado, o uso de cobertura morta proporcionou as maiores produções, nos trabalhos em que este tipo de manejo foi testado, embora tenha sido apontado como pouco viável economicamente (Rodriguez, 1957; Pacheco et al., 1973; Vasconcellos et al., 1976). O uso de herbicidas em área total também apresentou bons resultados no Estado de São Paulo, com laranja 'Hamlin' sobre limão 'Cravo' (Donadio et al., 1986). Os demais sistemas (adubos verdes ceifados ou incorporados, gradagens e sistemas mistos de gradagens com ceifa) têm apresentado comportamentos diferenciados de acordo com a região de estudo e ano de observação. Rodriguez (1969) comparou, em São Paulo, três sistemas de controle das ervas daninhas em pomar de laranja 'Hamlin' enxertada sobre laranja 'Caipira'. Para isso utilizou a vegetação natural de ervas daninhas ceifadas duas vezes por ano, adubação verde de guandu nos três primeiros anos, que depois foi 
substituído por soja-perene e ceifa duas vezes no período chuvoso mais uma gradeação no início do período seco. Os tratamentos não tiveram comportamento idêntico nos diferentes anos. Para a média de oito safras, as maiores produções foram obtidas com o tratamento de adubo verde, seguido do tratamento de ceifa mais gradeação, que produziram, respectivamente, $29 \%$ e $18 \%$ a mais do que o tratamento de mato ceifado. Passos et al. (1973) no Estado da Bahia, avaliaram o comportamento das plantas de laranja 'Baianinha' do quinto ao sétimo ano e constataram, também, que a produção não se comportou da mesma forma para cada tratamento, nas diferentes safras. No quinto ano o melhor desempenho foi o do tratamento grade no verão mais ceifa no inverno; no ano seguinte a maior produção foi obtida com grade permanente; enquanto que no sétimo ano o melhor foi adubação verde com Calopogonio mucunoides. Assim, na média dos três anos avaliados estes tratamentos apresentaram produtividades semelhantes. As produções mais baixas foram obtidas com ceifadeira permanente e culturas intercalares de mandioca (Manihot utilissima), fumo (Nicotiana tabacum), amendoim (Arachis hypogaea) e feijãomacassar (Vigna sinensis (L.) Savi), mesmo sendo produzidas apenas nos primeiros anos de formação do pomar. Pacheco et al. (1973), em Minas Gerais, observaram o efeito de sete práticas de manejo do solo em pomar de laranja 'Baianinha' enxertada sobre limão 'Cravo'. Para a primeira safra, os tratamentos cobertura morta e gradagens superficiais foram os mais produtivos enquanto que para a segunda safra estes mesmos tratamentos, bem como o tratamento caupi gradeado no florescimento, foram significativamente mais produtivos que os demais. Os piores desempenhos foram para os tratamentos de vegetação natural ceifada e soja-perene ceifada ou com colheita de sementes, enquanto que o tratamento caupi ceifado teve um comportamento intermediário.

A espécie escolhida como adubo verde também influencia o desempenho do pomar. Silva (1995) comparou o uso de sete espécies de leguminosas em pomar de laranja 'Pera' enxertada sobre tangerina 'Cleópatra'. Em relação à produção das primeiras safras, não ocorreram diferenças significativas entre os tratamentos, mas os tratamentos que receberam Crotalaria juncea e Cajanus cajan (guandu) apresentaram maior produção em números absolutos. 
$\mathrm{O}$ teor de nutrientes nas folhas das plantas cítricas pode sofrer variações de acordo com o manejo do solo. Gallo \& Rodriguez (1960) analisaram os teores foliares de nutrientes de laranjeira 'Hamlim' sobre laranjeira 'Caipira' e observaram que a adubação verde com mucuna e a cobertura morta aumentaram significativamente o teor de fósforo nas folhas, havendo uma correlação positiva com a produção de frutos. $\mathrm{O}$ mais baixo nível de fósforo foi obtido no tratamento de herbicida (óleo diesel). Para o nitrogênio, os teores mais elevados foram com herbicida e adubos verdes (mucuna preta Stizolobium sp. ou guandu Cajamus cajan) e os menores com cobertura morta de capim. O potássio foi mais elevado nos tratamentos herbicida e guandu. Para o cálcio os maiores níveis foram atingidos com cobertura morta, mucuna e duas lavras, e menores para herbicida e guandu. Para o magnésio, os níveis mais elevados ficaram com os tratamentos cobertura morta e mucuna. Wyss (1962), em um pomar de laranja 'Valência' na Jamaica, realizou um trabalho testando gradagens, cobertura morta, herbicida (dalapon) e capina. $\mathrm{O}$ autor observou que apenas o potássio apresentou diferenças entre os tratamentos, apresentando maior teor no tratamento capina em relação aos demais. Tucker et al. (1980) avaliaram durante dez anos o uso de herbicidas (bromacil e diuron) e cultivo mecânico em pomares comerciais de diversas variedades de laranjas na Flórida. A análise foliar revelou um aumento, porém não significativo, dos teores de nitrogênio e cálcio nos pomares manejados com cultivo mecânico.

Observa-se através dos resultados citados, que, de maneira geral, a presença de algum tipo de cobertura vegetal nas entrelinhas do pomar pode provocar uma competição por água e nutrientes com as plantas cítricas que pode levar à redução da produtividade. Se bem manejada, entretanto, a prática pode ter esse efeito minimizado, trazendo beneficios para a manutenção das condições do solo, podendo, inclusive contribuir na nutrição e na produção das plantas. Para isso é importante que se encontrem soluções adequadas para cada situação, com base na experimentação local. No presente trabalho avaliou-se o efeito de sistemas de manejo do solo em atributos químicos do solo e na nutrição, produção e qualidade dos frutos em um pomar de tangerina 'Poncã', em Londrina, Estado do Paraná. 


\section{4 Material e Métodos}

O clima da região, segundo a classificação de Köppen, é do tipo Cfa, subtropical úmido, com chuvas em todas as estações, podendo ocorrer seca no período de inverno (Corrêa et al., 1982). O experimento localizou-se no campus da Universidade Estadual de Londrina, em Londrina, Paraná, em latossolo roxo distrófico. A análise granulométrica apresentou $691 \mathrm{~g} \mathrm{~kg}^{-1}$ de argila, $216 \mathrm{~g} \mathrm{~kg}^{-1}$ de silte e $93 \mathrm{~g} \mathrm{~kg}^{-1}$ de areia. A análise química do solo, de acordo com a metodologia descrita em Empresa Brasileira de Pesquisa Agropecuária (1979), realizada por ocasião da instalação do pomar revelou os seguintes valores para a camada de $0-15 \mathrm{~cm}$ : $\mathrm{pH}\left(\mathrm{H}_{2} \mathrm{O}\right)=5,38$; matéria orgânica $=29,2 \mathrm{~g}$ $\mathrm{dm}^{-3} ; \mathrm{P}$ (Mehlich-1) $=2,04 \mathrm{mg} \mathrm{dm}{ }^{-3} ; \mathrm{K}^{+}=2,3 \mathrm{mmol}_{\mathrm{c}} \mathrm{dm}^{-3} ; \mathrm{Ca}^{+2}=45 \mathrm{mmol}_{\mathrm{c}} \mathrm{dm}^{-3} ; \mathrm{Mg}^{+2}$ $=19 \mathrm{mmol}_{\mathrm{c}} \mathrm{dm}^{-3} ; \mathrm{H}^{+}+\mathrm{Al}^{3+}=70 \mathrm{mmol}_{\mathrm{c}} \mathrm{dm}^{-3}$. Para a camada de $15-30 \mathrm{~cm}$, os resultados foram: $\mathrm{pH}\left(\mathrm{H}_{2} \mathrm{O}\right)=5,02$; matéria orgânica $=17,5 \mathrm{~g} \mathrm{dm}^{-3} ; \mathrm{P}($ Mehlish-1 $)=0,92 \mathrm{mg} \mathrm{dm}^{-3}$; $\mathrm{K}^{+}=1,1 \mathrm{mmol}_{\mathrm{c}} \mathrm{dm}^{-3} ; \mathrm{Ca}^{+2}=33 \mathrm{mmol}_{\mathrm{c}} \mathrm{dm}^{-3} ; \mathrm{Mg}^{+2}=32 \mathrm{mmol}_{\mathrm{c}} \mathrm{dm}^{-3} ; \mathrm{H}^{+}+\mathrm{Al}^{3+}=61$ $\mathrm{mmol}_{\mathrm{c}} \mathrm{dm}^{-3}$.

O pomar foi formado por plantas de tangerina var. 'Poncã' (Citrus reticulata Blanco), enxertadas sobre limão 'Cravo' (Citrus limonia Osbeck), plantadas em dezembro de 1985. O experimento constou de cinco tratamentos de manejo de solo, nas entrelinhas das plantas cítricas, que foram mantidos desde a sua instalação: a): cobertura verde durante todo o ano com a leguminosa perene Indigofera campestris Benth.; b): cobertura verde durante todo o ano com a leguminosa perene Arachis prostrata Bong. ex Benth.; c): cobertura durante a época de chuvas com mucuna cinza - Stizolobium pruriens (leguminosa anual); d): uso alternado de uma gradagem a disco (em maio-junho, no início do período seco) e de roçadeira (três a quatro vezes no período de chuvas); e): capina manual o ano inteiro.

A identificação das espécies de leguminosas foi realizada no Departamento de Botânica da ESALQ. Na linha de plantio o solo foi mantido permanentemente no limpo, através de capina. Os tratamentos de adubos verdes permanentes foram plantados através de mudas por ocasião da implantação do pomar e tem sido mantidos com capinas 
eventuais para reduzir a população de plantas invasoras, principalmente no caso de $I$. campestris, já que $A$. prostrata tem se mostrado mais competitiva. No tratamento de mucuna a semeadura foi feita anualmente, com espaçamento de $0,5 \times 0,5 \mathrm{~m}$ em setembro - outubro e as parcelas foram roçadas na fase de florescimento, em março - abril, deixando-se a palha sobre o terreno. $O$ espaçamento entre as plantas cítricas é de $6,0 \mathrm{x}$ $6,5 \mathrm{~m}$. Os tratamentos foram dispostos segundo delineamento experimental inteiramente ao acaso, com quatro repetições, tendo duas plantas úteis por parcela, bordaduras simples, e cada parcela teve $234 \mathrm{~m}^{2}$. A adubação mineral foi efetuada igualmente em todos os tratamentos com base nos teores dos elementos no solo e nas produções médias anuais, de acordo com as recomendações de Caetano (1986) e do Grupo Paulista de Adubação e Calagem para Citros (1988). Utilizou-se calcáreo dolomítico em 1986 (3 Mg ha $\left.^{-1}\right), 1989$ (3 $\left.\mathrm{Mg} \mathrm{ha}^{-1}\right), 1992$ (3,5 $\left.\mathrm{Mg} \mathrm{ha}^{-1}\right)$ e $1995\left(\mathrm{Mg} \mathrm{ha}^{-1}\right)$. As adubações foram realizadas em três épocas (setembro, novembro e fevereiro) sendo as quantidades de adubos aplicadas de $\mathrm{N}-\mathrm{P}_{2} \mathrm{O}_{5}-\mathrm{K}_{2} \mathrm{O}$ em quilogramas por hectare e por ano as seguintes: $1^{\circ}$ ano: $20-15-18 ; 2^{\circ}$ ano: $42-30-32 ; 3^{\circ}$ e $4^{\circ}$ anos: $46-38-46 ; 5^{\circ}$ e $6^{\circ}$ anos: $46-46-46$; $7^{\circ}$ ano: $145-77-80 ; 8^{\circ}$ e $9^{\circ}$ anos: $115-75-85$.

A produção das plantas foi avaliada anualmente em fevereiro - março, quando os frutos já se encontravam desenvolvidos porém ainda verdes, através da contagem do número de frutos por planta. Posteriormente, por ocasião da colheita, retirou-se uma amostra de dez frutos por planta para determinar o peso médio e a qualidade dos frutos (rendimento em suco, teor de sólidos solúveis, acidez e relação sólidos solúveis/acidez) de acordo com Instituto Adolfo Lutz (1985), no Departamento de Agronomia da UEL, entre os anos de 1992 a 1995. No ano de 1994 ocorreram problemas na metodologia para determinação da acidez e sólidos solúveis e por esse motivo aqueles resultados para aquele ano não foram utilizados. Com o número de frutos por planta e o peso médio dos frutos calculou-se a produção em quilogramas por planta. A análise do tecido foliar foi realizada no setor de Nutrição Mineral de Plantas, do Departamento de Química da ESALQ/USP, no ano de 1995. A coleta das folhas para a análise foi efetuada conforme a recomendação do Grupo Paulista de Adubação e Calagem para Citros (1988), nas plantas 
úteis, no mês de fevereiro. A análise química das folhas seguiu a metodologia descrita por Sarruge \& Haag (1974). Nas amostras de solo foi efetuada a análise química (teores de $\mathrm{C}, \mathrm{N}, \mathrm{P}, \mathrm{K}, \mathrm{Ca}, \mathrm{Mg}, \mathrm{H}+\mathrm{Al}, \mathrm{pH}, \mathrm{S}, \mathrm{T}$, e V\%) no Departamento de Química da ESALQ/USP, segundo a metodologia de RAIJ et al. (1987). Coletaram-se seis subamostras de solo por parcela nas linhas e entrelinhas da cultura, as quais foram misturadas para compor uma amostra por repetição. Com os resultados obtidos foi efetuada a análise da variância (teste F) e a seguir as médias foram comparadas pelo teste de Tukey.

\section{5 Resultados e Discussão}

A análise de variância para a produção, em número e em $\mathrm{kg}$ de frutos por planta, encontra-se na Tabela 32, do Anexo A.

A produção das plantas ao longo dos anos de 1992 a 1995 encontra-se na Tabela 1 (em número de frutos por planta) e na Tabela 2 (em quilogramas de fruto por planta). As produtividades médias alcançadas pelas plantas no presente trabalho, em torno de 600 a 700 frutos por planta (Tabela 1), se transformadas em quilogramas, com peso médio dos frutos (Tabela 3), atingem de 110 a $178 \mathrm{~kg}$ de fruto por planta. Essa é uma produção satisfatória, considerando a produtividade média de $100 \mathrm{~kg}$ por planta, obtida com a mesma combinação copa/porta-enxerto em Cordeirópolis, SP (Hiroce et al., 1981).

Observa-se que, pela análise estatística, os tratamentos de manejo do solo não provocaram diferenças significativas na produtividade das plantas (Tabelas 1 e 2) ao nível de $0,05 \%$ de significância. Em termos de números absolutos, entretanto, o tratamento Grade/Roçadeira apresentou maior produção na médias dos anos de observação. Este desempenho pode ser atribuído à ausência de vegetação durante a estação seca do ano, o que deve ter reduzido a competição pela água e nutrientes do solo. Carvalho et al. (1995) e Vasconcelos et al. (1976) com laranja 'Pera' e Santinoni \& Silva (1995) com tangerina 'Mexerica' na Argentina também observaram que este mesmo tratamento 
Tabela 1. Produção de tangerina 'Poncã' em tratamentos de manejo de solo e anos de observação, em número de frutos por planta (médias de quatro repetições).

\begin{tabular}{lccccc}
\hline Tratamento & \multicolumn{5}{c}{ Ano } \\
\cline { 2 - 6 } & 1992 & 1993 & 1994 & 1995 & $92-95$ \\
\hline I. campestris & $756,0 \mathrm{a}^{*}$ & $523,0 \mathrm{a}$ & $708,2 \mathrm{a}$ & $872,6 \mathrm{a}$ & $714,9 \mathrm{a}$ \\
A. prostrata & $606,4 \mathrm{a}$ & $473,5 \mathrm{a}$ & $697,9 \mathrm{a}$ & $635,7 \mathrm{a}$ & $603,4 \mathrm{a}$ \\
Mucuna cinza & $654,6 \mathrm{a}$ & $526,1 \mathrm{a}$ & $563,0 \mathrm{a}$ & $667,7 \mathrm{a}$ & $602,9 \mathrm{a}$ \\
Roçad./Grade & $974,0 \mathrm{a}$ & $618,0 \mathrm{a}$ & $646,6 \mathrm{a}$ & $737,6 \mathrm{a}$ & $744,0 \mathrm{a}$ \\
Capina & $813,0 \mathrm{a}$ & $576,1 \mathrm{a}$ & $612,1 \mathrm{a}$ & $640,6 \mathrm{a}$ & $660,4 \mathrm{a}$ \\
\hline D.M.S. & 447,21 & 373,80 & 563,28 & 608,01 & 303,07 \\
C.V. (\%) & 26,90 & 31,49 & 39,93 & 39,14 & 20,86 \\
\hline
\end{tabular}

* Médias seguidas da mesma letra, em cada coluna, não diferem estatisticamente, pelo teste de Tukey, ao nível de $5 \%$ de significância.

Tabela 2. Produção de tangerina 'Poncã' em tratamentos de manejo de solo e anos de observação, em quilogramas de frutos por planta (médiasde quatro repetições).

\begin{tabular}{ccrccc}
\hline Tratamento & \multicolumn{5}{c}{ Ano } \\
\cline { 2 - 6 } & 1992 & \multicolumn{1}{c}{1993} & 1994 & 1995 & $92-95$ \\
\hline I. compestris & $119,2 \mathrm{a}^{*}$ & $112,9 \mathrm{a}$ & $134,9 \mathrm{a}$ & $160,9 \mathrm{a}$ & $132,0 \mathrm{a}$ \\
A. prostrata & $110,0 \mathrm{a}$ & $89,5 \mathrm{a}$ & $139,3 \mathrm{a}$ & $119,1 \mathrm{a}$ & $114,5 \mathrm{a}$ \\
Mucuna cinza & $118,8 \mathrm{a}$ & $105,9 \mathrm{a}$ & $111,3 \mathrm{a}$ & $133,6 \mathrm{a}$ & $117,4 \mathrm{a}$ \\
Roçad/Grade & $178,8 \mathrm{a}$ & $115,7 \mathrm{a}$ & $130,0 \mathrm{a}$ & $148,3 \mathrm{a}$ & $143,2 \mathrm{a}$ \\
Capina & $145,0 \mathrm{a}$ & $112,3 \mathrm{a}$ & $127,6 \mathrm{a}$ & $127,7 \mathrm{a}$ & $127,9 \mathrm{a}$ \\
\hline D.M.S. & 79,58 & 69,32 & 112,02 & 121,08 & 58,62 \\
C.V. (\%) & 27,11 & 29,64 & 39,86 & 40,18 & 21,13 \\
\hline
\end{tabular}

* Médias seguidas da mesma letra, em cada coluna, não diferem estatisticamente, pelo teste de Tukey, ao nível de $5 \%$ de significância. 
promoveu a maior produção. Passos (1973) também obteve maiores safras com o tratamento de ceifa na estação chuvosa e gradeação na estação seca em um dos anos de observação, mas este melhor comportamento não se repetiu em todas as safras, provavelmente em função das condições climáticas. Mustaffa (1988) obteve maior produção de tangerina 'Coorg', na Índia, quando submetida ao tratamento de "mulch" de folhas secas de floresta, e menor produção no tratamento de vegetação natural ceifada. Esse último autor atribuiu este desempenho à umidade do solo, que foi significativamente maior quando o solo foi coberto com "mulch", dadas as condições de "stress" hídrico provocadas pelo clima monsônico. Nos resultados do presente trabalho, se houve limitação por água e nutrientes na presença das plantas de cobertura, esta não suficiente para provocar diferenças significativas entre os tratamentos. Analisando-se os dados climáticos nos anos do experimento, pode-se observar que a ocorrência de chuvas na região durante o período úmido do ano foi equivalente à media histórica da região (Corrêa et al., 1982), coincidindo com o período produtivo da tangerineira 'Poncã' (setembro a março).

Resultados equivalentes de produção para tipos de manejo têm sido encontrados também em outros trabalhos (Passos et al., 1973; Bouma \& Mcintyre, 1963). Num experimento fatorial com citros na Austrália, envolvendo quatro sistemas de manejo do solo com níveis de adubação nitrogenada, combinações de copa/cavalo, níveis de irrigação e níveis de calcário, Bouma \& Mcintyre (1963) não encontraram diferenças de produção para os tipos de manejo do solo durante 13 anos de observação. Segundo esses autores, o manejo teve efeito sobre as condições físicas do solo mas não o suficiente para afetar o desempenho das plantas, que tiveram maior influência do fator nutricional, principalmente de nitrogênio e fósforo.

A análise de variância para os resultados de qualidade dos frutos está representado na Tabela 33, no Anexo A. O peso médio e o rendimento em suco (em porcentagem do peso) não sofreram influência significativa dos tratamentos para o nível de $0,05 \%$ de significância (Tabela 3). Para as características do suco (Tabela 4), também não foram verificadas diferenças significativas ao nível de $0,05 \%$ de significância na 
quantidade de sólidos solúveis, acidez total titulável e relação sólidos solúveis/acidez. Estes resultados se devem, provavelmente, ao fato de que as alterações provocadas no solo sejam um fator secundário na qualidade dos frutos cítricos, como informaram Reuther (1973) e Ortolani et al. (1991), enquanto que as condições climáticas desempenham um papel determinante nessa qualidade. Koller et al. (1977) não encontraram diferenças significativas para a qualidade dos frutos de laranja 'Valência' e 'Baianinha' quando utilizaram ceifa ou gradeação, o mesmo acontecendo com Santinoni \& Silva (1995) para plantas de tangerina 'Mexerica' submetidas a oito sistemas de manejo. Entretanto, em alguns trabalhos ocorreram diferenças para o teor de sólidos solúveis, que foi maior para o tratamento de ceifa (Mustaffa, 1988) ou para os tratamentos que envolviam duas espécies de leguminosas (Vasconcelos et al., 1977). Cary (1968) observou que o parâmetro mais influenciado pelo manejo do solo foi o

Tabela 3. Peso médio (em gramas) dos frutos de tangerina Poncã e rendimento em suco (em \% do peso total) em tratamentos de manejo de solo e anos de observação (médias de quatro repetições).

\begin{tabular}{|c|c|c|c|c|c|c|c|c|}
\hline & \multicolumn{4}{|c|}{ Peso (g) } & \multicolumn{4}{|c|}{ Rendimento em suco (\%) } \\
\hline \multirow[t]{2}{*}{ Tratamento } & \multicolumn{4}{|c|}{ Ano } & \multicolumn{4}{|c|}{ Ano } \\
\hline & 1992 & 1993 & 1994 & 1995 & 1992 & 1993 & 1994 & 1995 \\
\hline I. campestris & $157,6 a$ & $197,4 a$ & $190,4 a$ & $184,4 a$ & $41,8 \mathrm{a}$ & $41,7 a$ & $49,1 \mathrm{a}$ & $45,7 \mathrm{a}$ \\
\hline A. prostrata & $181,4 \mathrm{a}$ & $189,0 \mathrm{a}$ & $199,6 a$ & $187,4 a$ & $39,3 \mathrm{a}$ & $41,2 a$ & $49,4 a$ & $42,5 \mathrm{a}$ \\
\hline Mucuna cinza & $181,4 a$ & $201,2 a$ & $197,6 a$ & $200,0 \mathrm{a}$ & $41,7 \mathrm{a}$ & $40,3 a$ & $48,0 \mathrm{a}$ & $41,7 \mathrm{a}$ \\
\hline Roçad./Grade & $183,6 \mathrm{a}$ & $187,2 \mathrm{a}$ & $201,1 \mathrm{a}$ & $201,1 \mathrm{a}$ & $42,2 \mathrm{a}$ & $39,1 \mathrm{a}$ & $46,8 \mathrm{a}$ & $44,7 \mathrm{a}$ \\
\hline Capina & $178,3 \mathrm{a}$ & $193,1 \mathrm{a}$ & $208,5 \mathrm{a}$ & $199,4 a$ & $38,6 a$ & $39,1 \mathrm{a}$ & $46,7 \mathrm{a}$ & $45,6 a$ \\
\hline D.M.S. & 41,69 & 44,46 & 68,70 & 56,12 & 7,05 & 3,69 & 5,21 & 6,74 \\
\hline C.V. (\%) & 10,44 & 10,51 & 15,76 & 13,21 & 7,92 & 4,19 & 4,96 & 7,01 \\
\hline
\end{tabular}

* Médias seguidas da mesma letra, em cada coluna, não diferem estatisticamente, pelo teste de Tukey, ao nível de $5 \%$ de significância. 
Tabela 4. Teor de sólidos solúveis ( $\mathrm{em}^{\circ}$ Brix), teor de acidez total (em $\%$, p/v) e relação sólidos solúveis/acidez total (ratio) dos frutos de tangerina 'Poncã' em tratamentos de manejo de solo e anos de observação(médias de quatro repetições).

\begin{tabular}{|c|c|c|c|c|c|c|c|c|c|}
\hline \multirow{3}{*}{ Tratamento } & \multicolumn{3}{|c|}{$\begin{array}{c}\text { Sólidos Solúveis } \\
\text { ( }{ }^{\circ} \text { Brix) }\end{array}$} & \multicolumn{3}{|c|}{$\begin{array}{c}\text { Acidez } \\
\text { (\%) }\end{array}$} & \multicolumn{3}{|c|}{ Ratio } \\
\hline & \multicolumn{3}{|c|}{ Ano } & \multicolumn{3}{|c|}{ Ano } & \multicolumn{3}{|c|}{ Ano } \\
\hline & 1992 & 1993 & 1995 & 1992 & 1993 & 1995 & 1992 & 1993 & 1995 \\
\hline I. campestris & $9,0 a^{*}$ & $9,9 a$ & $10,3 a$ & $\overline{0,60 a}$ & $0,45 a$ & $0,45 a$ & $15,11 \mathrm{a}$ & $21,79 a$ & $23,32 a$ \\
\hline A. prostrata & $9,1 \mathrm{a}$ & $10,2 \mathrm{a}$ & $10,8 \mathrm{a}$ & $0,61 \mathrm{a}$ & $0,46 \mathrm{a}$ & $0,47 a$ & $15,18 \mathrm{a}$ & $24,12 \mathrm{a}$ & $23,38 \mathrm{a}$ \\
\hline Mucuna cinza & $9,1 \mathrm{a}$ & $9,9 a$ & $10,8 \mathrm{a}$ & $0,64 a$ & $0,49 \mathrm{a}$ & $0,51 \mathrm{a}$ & $14,50 \mathrm{a}$ & $20,41 \mathrm{a}$ & $21,56 a$ \\
\hline Roçad./Grade & $9,0 \mathrm{a}$ & $10,1 \mathrm{a}$ & $10,7 \mathrm{a}$ & $0,56 a$ & $0,46 a$ & $0,42 a$ & $16,32 a$ & $21,86 a$ & $26,11 \mathrm{a}$ \\
\hline Capina & $8,8 a$ & $10,1 \mathrm{a}$ & $10,4 a$ & $0,60 a$ & $0,43 a$ & $0,37 a$ & $14,85 \mathrm{a}$ & $23,03 a$ & $28,66 a$ \\
\hline D.M.S. & 0,67 & 1,64 & 1,68 & 0,15 & $\overline{0,08}$ & 0,12 & 5,17 & 4,37 & 7,36 \\
\hline C.V. (\%) & 3,43 & 7,34 & 7,29 & 11,50 & 8,46 & 12,26 & 10,64 & 13,17 & 13,69 \\
\hline
\end{tabular}

* Médias seguidas da mesma letra, em cada coluna, não diferem estatisticamente, pelo teste de Tukey, ao nível de $5 \%$ de significância.

rendimento em suco, que foi maior no manejo com cultivo do que sem cultivo. Entretanto, este fato não foi observado em todos os anos de observação, evidenciando que algum outro fator, provavelmente a quantidade de água disponível no solo, deve estar envolvido na quantidade de suco das frutas. Da mesma forma, Vasconcelos et al. (1977) obtiveram os maiores rendimentos em suco nos tratamentos em que a competição por água foi reduzida (capina, cobertura morta, herbicida e gradagem) enquanto que o mais baixo nível foi obtido quando houve competição com outras plantas através da adubação verde permanente.

A análise de variância para os dados de teores de nutrientes nas folhas são apresentados na Tabela 34 do Anexo A e as médias obtidas para a análise foliar segundo os tratamentos encontra-se na Tabela 5. A ausência de diferença significativa para a produtividade entre os tratamentos do presente trabalho mostra-se coerente com os 
Tabela 5. Teor de nutrientes nas folhas de tangerineira 'Poncã' (médias de quatro repetições).

\begin{tabular}{|c|c|c|c|c|c|c|c|c|c|c|c|}
\hline Tratamento & $\mathbf{N}$ & $\mathbf{P}$ & $\bar{K}$ & $\overline{\mathrm{Ca}}$ & $\mathrm{Mg}$ & S & B & $\mathrm{Cu}$ & $\mathrm{Fe}$ & $\mathrm{Mn}$ & $\mathrm{Zn}$ \\
\hline & \multicolumn{6}{|c|}{$\mathrm{g} \mathrm{kg}^{-1}$} & \multicolumn{5}{|c|}{$\mathrm{mg} \mathrm{kg}^{-1}$} \\
\hline 1. campestris & $29,3 \mathrm{a}^{*}$ & $1,2 \mathrm{a}$ & $6,0 \mathrm{a}$ & $43,8 \mathrm{a}$ & $3,2 \mathrm{a}$ & $2,3 a$ & $77 a$ & $4 \mathrm{a}$ & $224 a$ & $80 a$ & $16 \mathrm{a}$ \\
\hline A. prostrata & $28,7 \mathrm{a}$ & $1,3 \mathrm{a}$ & $7,1 \mathrm{a}$ & $39,6 \mathrm{a}$ & $3,2 \mathrm{a}$ & $1,2 \mathrm{~b}$ & $75 \mathrm{a}$ & $5 a$ & $201 \mathrm{a}$ & $75 a$ & $16 \mathrm{a}$ \\
\hline Muc. cinza & $27,6 \mathrm{a}$ & $1,2 \mathrm{a}$ & $8,2 \mathrm{a}$ & $33,1 \mathrm{a}$ & $2,9 a$ & $1,6 \mathrm{ab}$ & $66 a$ & $5 a$ & $199 a$ & $111 \mathrm{a}$ & $14 \mathrm{a}$ \\
\hline Roçad./Grade & $28,2 \mathrm{a}$ & $1,1 \mathrm{a}$ & $6,7 \mathrm{a}$ & $38,3 \mathrm{a}$ & $3,0 \mathrm{a}$ & $1,4 \mathrm{~b}$ & $85 a$ & $5 \mathrm{a}$ & $188 \mathrm{a}$ & $140 \mathrm{a}$ & $14 \mathrm{a}$ \\
\hline Capina & $29,2 \mathrm{a}$ & $1,2 \mathrm{a}$ & $7,2 \mathrm{a}$ & $33,2 \mathrm{a}$ & $3,3 \mathbf{a}$ & $1,4 \mathrm{~b}$ & $80 a$ & $4 \mathrm{a}$ & 228 a & $75 \mathrm{a}$ & $16 \mathrm{a}$ \\
\hline D.M.S. & 6,8 & 3,1 & 0,40 & 15,0 & 1,5 & 0,8 & 26,84 & $.3,71$ & 81,91 & 155,01 & 3,88 \\
\hline C.V. (\%) & 10,96 & 11,69 & 26,12 & 18,22 & 22,13 & 23,40 & 16,06 & 35,75 & 18,02 & 73,63 & 11,71 \\
\hline
\end{tabular}

* Médias seguidas da mesma letra, na vertical, não diferem estatisticamente, pelo teste de Tukey, ao nível de $5 \%$ de significância.

resultados obtidos acerca do estado nutricional das plantas, pois observa-se que, à exceção do enxofre (Tabela 5), não houve diferenças estatísticas significativas para os elementos. Isso evidencia que, apesar das diferenças de condições proporcionadas pelos tratamentos, as plantas absorveram quantidades equivalentes de nutrientes. Comparandose os teores de nutrientes obtidos nas folhas com as faixas de interpretação existentes (Malavolta \& Violante Netto, 1989), verifica-se que os elementos $\mathrm{N}, \mathrm{P}, \mathrm{Ca}, \mathrm{Mg}, \mathrm{B}, \mathrm{e}$ $\mathrm{Cu}$ encontram-se em níveis adequados e os de Fe e Mn estão altos para a variedade. Os níveis de $\mathrm{K}$ e $\mathrm{S}$ estão baixos, e o $\mathrm{Zn}$ está deficiente. A ausência de diferenças entre os tratamentos deve-se, provavelmente, à adubação, realizada igualmente em todos os tratamentos, evidenciando uma influência mais importante do aspecto químico na nutrição e produção das plantas, do que do tipo de manejo do solo. Essa tendência já tinha sido observada no desenvolvimento vegetativo e nas primeiras safras do pomar em estudo (Neves \& Nilo Gonzalez, 1992; Nilo Gonzalez \& Neves, 1992). Resultados de Mustaffa (1988) também levaram a conclusão similar.

Confirmando este fato, a análise química do solo das entrelinhas analisadas não sofreram influência do manejo do solo, provavelmente em função das adubações e 
calagens realizadas uniformemente no pomar. A análise de variância para os dados da análise química do solo na entrelinha do pomar são apresentados na Tabela 35 do Anexo A e as médias obtidas para a análise química do solo das entrelinhas do pomar nas profundidades de 0-20 cm e 20-40 cm encontram-se na Tabela 6. Observa-se que o uso de $A$. prostrata e de roçadeira/grade tiveram efeito significativamente positivo no teor de

Tabela 6. Análise química do solo das entrelinhas do pomar nas profundidades de 0-20 cm e 20-40 cm, quando submetido aos tratamentos de manejo do solo (média de quatro repetições).

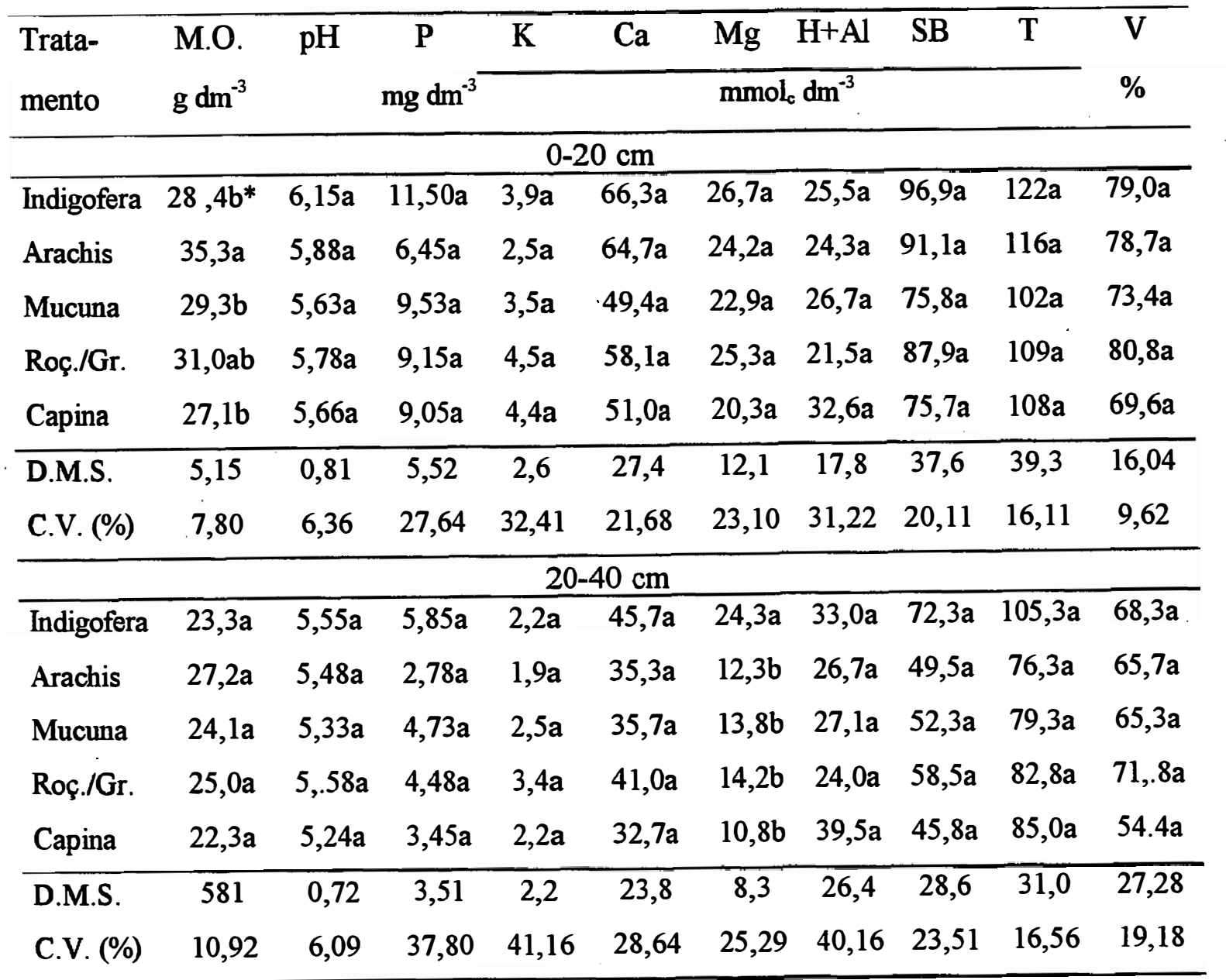

* Médias seguidas da mesma letra, na vertical, não diferem estatisticamente, pelo teste de Tukey, ao nível de $5 \%$ de significância. 
matéria orgânica do solo na profundidade $0-20 \mathrm{~cm}$, em relação aos demais tratamentos, refletindo a contribuição em massa verde proporcionada por estes tratamentos. $\mathrm{O}$ teor de matéria orgânica passou de $29,2 \mathrm{~g} \mathrm{dm}^{-3}$, no início do experimento, para $35,3 \mathrm{~g} \mathrm{dm}^{-3} \mathrm{com}$ A. prostrata e para $31,0 \mathrm{~g} \mathrm{dm}^{-3}$ com roçadeira/grade, na camada 0-20 cm. Os tratamentos de $I$. campestris e mucuna mantiveram aproximadamente o mesmo teor, enquanto que o solo permanentemente limpo através de capina teve o teor de matéria orgânica reduzido em relação às condições iniciais. Para a profundidade de $20-40 \mathrm{~cm}$ não houve diferenças entre os tratamentos, mas em números absolutos ocorreu uma repetição do desempenho apresentado na camada superior. Koller et al. (1977) observaram um aumento no teor de matéria orgânica do solo até a profundidade de $45 \mathrm{~cm}$ quando utilizaram vegetação ceifada em comparação com uma aração e três gradagens por ano. Menegucci et al. (1995), após o cultivo de Crotaloria juncea durante uma safra em pomar cítrico, observaram que a matéria orgânica do solo teve um aumento de 3,8 \% (antes do plantio do adubo verde) para 5,1\% (dois meses depois do corte do adubo verde), enquanto que nas parcelas onde não se plantou a leguminosa este aumento foi de 3,8 \% para 4,4\%, devido à incorporação da vegetação nativa. Silva (1995) observou, após quatro cultivos de sete espécies de leguminosas anuais, que o teor de matéria orgânica três meses após o corte foi aumentado significativamente para todas as espécies testadas. 0 menor incremento foi observado com mucuna anã e os maiores foram obtidos pelos pelos tratamentos Crotalaria juncea e 2NPK (sem adubo verde, mas com vegetação nativa). Trabalhos realizados em outras condições, como o de Proebsting (1952) não registraram o mesmo comportamento. Esse autor testou leguminosas em pomares cítricos na Califórnia e observou um pequeno porém não significativo aumento da matéria orgânica do solo, quando comparou com a testemunha mantida no limpo, depois de 25 anos de ensaio. Entretanto, naquele trabalho o autor analisou uma camada de solo de 30 $\mathrm{cm}$. Este procedimento pode ter diluído o efeito da incorporação de matéria orgânica pelos restos vegetais, que foi mais restrito aos primeiros $10-12 \mathrm{~cm}$ do solo.

A análise da variância para os dados da análise química do solo na linha de plantio encontram-se na Tabela 36 do Anexo A e as médias obtidas para os diferentes 
Tabela 7. Análise química do solo da projeção da copa do pomar nas profundidades de 0$20 \mathrm{~cm}$ e $20-40 \mathrm{~cm}$, quando submetido aos tratamentos de manejo do solo (média de quatro repetições).

\begin{tabular}{|c|c|c|c|c|c|c|c|c|c|c|}
\hline \multirow{2}{*}{$\begin{array}{l}\text { Trata- } \\
\text { mento }\end{array}$} & \multirow{2}{*}{$\begin{array}{l}\text { M. } \bar{O} \\
\mathrm{~g} \mathrm{dm}^{-3}\end{array}$} & \multirow[t]{2}{*}{$\overline{\mathrm{pH}}$} & \multirow{2}{*}{$\begin{array}{c}P \\
m g \mathrm{dm}^{-3}\end{array}$} & $\mathrm{~K}$ & $\overline{\mathrm{Ca}}$ & $\mathbf{M g}$ & $\mathrm{H}+\mathrm{Al}$ & SB & $\mathbf{T}$ & \multirow{2}{*}{$\begin{array}{l}\mathrm{V} \\
\%\end{array}$} \\
\hline & & & & \multicolumn{6}{|c|}{$\mathrm{mmol}_{\mathrm{c}} \mathrm{dm}^{-3}$} & \\
\hline \multicolumn{11}{|c|}{$0-20 \mathrm{~cm}$} \\
\hline Indigofera & $26,9 a$ & $5,28 \mathrm{a}$ & $66,83 a$ & $3,4 a$ & $55,8 \mathrm{a}$ & $20,1 \mathrm{a}$ & $44,8 a$ & $79,5 a$ & $124,3 a$ & $\overline{63,4 a}$ \\
\hline Arachis & $26,4 a$ & $5,21 \mathrm{a}$ & $99,65 a$ & $3,7 \mathrm{a}$ & $51,1 \mathrm{a}$ & $22,9 a$ & $42,5 a$ & $77,8 \mathrm{a}$ & $120,0 \mathrm{a}$ & $62,6 a$ \\
\hline Mucuna & $26,7 \mathrm{a}$ & $4,96 a$ & $135,30 \mathrm{a}$ & $3,7 \mathrm{a}$ & $44,3 a$ & $14,8 \mathrm{a}$ & $58,9 \mathrm{a}$ & $63,0 \mathrm{a}$ & $121,8 \mathrm{a}$ & $51,2 a$ \\
\hline Roç./Gr. & $24,8 \mathrm{a}$ & $5,14 a$ & $39,65 a$ & $3,8 \mathrm{a}$ & $49,8 a$ & $19,1 \mathrm{a}$ & $46,9 a$ & $72,8 a$ & $119,8 \mathrm{a}$ & $60,8 a$ \\
\hline Capina & $24,7 \mathrm{a}$ & $4,89 a$ & $30,65 a$ & $2,4 a$ & $34,5 \mathrm{a}$ & $13,8 \mathrm{a}$ & $52,5 \mathrm{a}$ & $50,5 a$ & $103,3 a$ & $48,0 \mathrm{a}$ \\
\hline D.M.S. & 6,58 & 0,73 & 152,95 & 3,07 & 31,68 & 15,32 & 21,17 & 47,00 & 37,92 & 23,89 \\
\hline (\%) & 11,63 & 6,60 & $94, C$ & 41,37 & 30,78 & 38,65 & 19,72 & 31,31 & 14,73 & 19,12 \\
\hline \multicolumn{11}{|c|}{$20-40 \mathrm{~cm}$} \\
\hline Indigofera & $25,6 a$ & 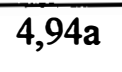 & $37,15 a$ & $3,9 a$ & $38,2 a$ & $13,4 a$ & $53,4 a$ & $55,8 \mathrm{a}$ & $109,0 \mathrm{a}$ & $50,8 a$ \\
\hline Ararhis & $26,0 \mathrm{a}$ & $4,76 a$ & $14,30 \mathrm{a}$ & $3,1 \mathrm{a}$ & $31,8 \mathrm{a}$ & $12,5 \mathrm{~b}$ & J & 47 & $104,5 \mathrm{a}$ & $45,3 \mathrm{a}$ \\
\hline Mucuna & $23,9 \mathrm{a}$ & $4,76 a$ & 46 & $4,0 a$ & $34,3 \mathrm{a}$ & $11,6 b$ & $61,2 \mathrm{a}$ & $49,8 \mathrm{a}$ & $111,0 \mathrm{a}$ & $45,1 \mathrm{a}$ \\
\hline c./Gr. & $25,0 \mathrm{a}$ & $5,06 \mathrm{a}$ & $14,83 a$ & $3,5 \mathrm{a}$ & $41,9 a$ & $13,9 b$ & $48,7 \mathrm{a}$ & $59,5 \mathrm{a}$ & $107,8 \mathrm{a}$ & $54,9 \mathrm{a}$ \\
\hline Capina & $22,3 a$ & $4,91 \mathrm{a}$ & $9,18 \mathrm{a}$ & $2,7 \mathrm{a}$ & $29,4 a$ & $11,6 \mathrm{~b}$ & $48,2 a$ & $43,5 \mathrm{a}$ & $91,8 a$ & $47,5 \mathrm{a}$ \\
\hline . IVI.S. & 5,90 & 0,51 & 47,30 & 0 & 4 & 6,85 & 22,63 & 22,67 & 26,14 & 16,95 \\
\hline V. (\%) & 10,99 & 4,74 & 89,06 & 53,39 & 21,70 & 24,89 & 19,27 & 20,28 & 11,42 & 15,93 \\
\hline
\end{tabular}

* Médias seguidas da mesma letra, na vertical, não diferem estatisticamente, pelo teste de Tukey, ao nível de $5 \%$ de significância.

tratamentos estão na Tabela 7. Nessa Tabela pode-se observar que não houve diferenças entre os tratamentos nas duas profundidades amostradas para os teores de nutrientes, bem como para o teor de matéria orgânica, evidenciando a condição de igualdade que foi proporcionada nesta região do pomar, pois todos os tratamentos eram capinados manualmente na linha de plantio. Comparando-se os resultados da análise química para a 
profundidade $0-20 \mathrm{~cm}$ observados nas entrelinhas (Tabela 6) com os observados na projeção da copa (Tabela 7), verifica-se que na projeção da copa os valores de $\mathrm{pH}, \mathrm{Ca}$, Mg e soma de bases (SB) são mais baixos, e o valor de $\mathrm{H}+\mathrm{Al}$ é mais alto, provavelmente em função da dificuldade de se espalhar o calcário mecanicamente nessa região. Da mesma forma, nessa região observa-se mais altos valores de $\mathrm{P}$ e de $\mathrm{K}$, indicando o local preferencial das adubações, que nestas condições foram realizadas manualmente. Quanto aos teores de matéria orgânica, observa-se que na projeção da copa os teores são mais baixos do que na entrelinha para todos os tratamentos, evidenciando que o acréscimo em material vegetal proporcionado pelas plantas cítricas é menor do que os dos tratamentos testados, inclusive para o tratamento capina.

\section{6 Conclusões}

Através da análise dos resultados deste trabalho, pode-se concluir que:

- Os tratamentos de manejo de solo utilizados neste experimento não tiveram influência significativa sobre a produção e qualidade de frutos de tangerina 'Poncã'. Em números absolutos a maior produção ocorreu no tratamento de gradagem na época seca e roçadeira na época de chuvas.

- Os tratamentos de manejo do solo não afetaram significativamente os teores de nutrientes no solo e o estado nutricional das plantas de tangerina 'Poncã'.

- O teor de matéria orgânica do solo das entrelinhas do pomar na camada de $0-20 \mathrm{~cm}$ foi aumentado no tratamento com cobertura vegetal de $A$. prostrata, seguido de gradagem na época seca e roçadeira na época de chuvas. 
4 EFEITO DO MANEJO DO SOLO NO SISTEMA RADICULAR DE TANGERINA 'PONCÃ' ENXERTADA SOBRE LIMÃO 'CRAVO' E EM ATRIBUTOS FÍSICOS DE UM LATOSSOLO ROXO 


\section{EFEITO DO MANEJO DO SOLO NO SISTEMA RADICULAR DE TANGERINA 'PONCÃ' ENXERTADA SOBRE LIMÃO 'CRAVO' E EM ATRIBUTOS FÍSICOS DE UM LATOSSOLO ROXO}

\subsection{Resumo}

Estudou-se a quantidade e a distribuição das raízes, pelo método da trincheira, e a estruturação do solo, pelo método do perfil cultural, em um pomar de tangerina var. 'Poncã' (Citrus reticulata Blanco), enxertada sobre limoeiro 'Cravo' (Citrus limonia Osbeck) em Londrina-PR com cinco sistemas de manejo do solo, em latossolo roxo. Os tratamentos foram: cobertura com Indigofera campestris Benth.; cobertura com Arachis prostrata Bong. ex Benth.; mucuna cinza - Stizolobium pruriens na época de chuvas; gradagem a disco (no período seco)/ roçadeira (período de chuvas); capina manual. A quantidade total de raízes não apresentou diferenças entre os tratamentos, mas a distribuição do sistema radicular foi significativamente alterada. A presença de $A$. prostrata provocou concentração e aprofundamento das raízes. $\mathrm{O}$ perfil cultural indicou zonas de compactação nos tratamentos Roçadeira/Grade e Capina, que, no entanto, não impediram o crescimento das raízes de citrus.

\subsection{Summary: EFFECT OF SOIL MANAGEMENT ON SOIL PHYSICAL PROPERTIES AND ON ROOT SYSTEM OF 'PONCÃ' TANGERINE ON 'RANGPUR LIME' ROOTSTOCK IN A BRAZILIAN OXISOL}


A trial with 'Poncã' tangerine (Citrus reticulata Blanco) on 'Rangpur Lime' rootstock was carried out in Londrina-PR in an oxisol to study the effect of the orchard floor management on soil physical properties by the cultural profile method, and citrus root system, by the profile wall method. Five treatments were used: permanent cover with Indigofera campestris Benth; permanent cover with Arachis prostrata Bong. ex Benth; 'mucuna cinza' (Stizolobium pruriens.) during spring and summer; alternate mowing (rainy season) /tillage (dry season); and hand hoeing. After nine years, the total amount of citrus roots observed by the profile wall method was not affected by soil management treatments. The presence of perennial leguminous plants in the orchard inter-row limited the presence of citrus roots to the region of the profile where roots of the cover plants were absent. This was compensatad by a significant increase in citrus root system deepning in $A$. prostrata treatment. The cultural profile showed regions with high soil bulk density in the treatments mowing/tillage and hand hoeing, but citrus roots grew in that regions as well as in the others with low soil bulk density.

\section{3 Introdução}

Apesar da importância do tema, tem sido pouco estudada a influência de práticas de manejo do solo no desenvolvimento do sistema radicular das plantas cítricas. De acordo com Castle et al. (1989), o conhecimento sobre a taxa de crescimento, a extensão e a distribuição do sistema radicular é essencial à produção de citros, pela sua importância na nutrição e absorção de água e porque é diretamente afetado por tratos culturais, adubação e irrigação. Segundo esses autores, produzir bem significa manejar bem o sistema radicular.

Os citros apresentam, de maneira geral, cerca de $60 \%$ de suas raízes a até 0,60-0,75 m de profundidade e cerca de $90 \%$ a $1,5 \mathrm{~m}$ de profundidade (Ford, 1953; Montenegro, 1960). Mazza et al. (1994) observaram que a compactação do solo, com redução da macroporosidade de $32 \%$ para $10 \%$, provocou uma redução importante no sistema radicular dos citros. Na Austrália, Frith (1952) estudou o sistema radicular dos 
citros em um experimento com quatro tipos de manejo do solo (cultivo mecânico no verão e adubo verde no inverno, o mesmo tratamento mais esterco de curral, vegetação natural ceifada, e herbicida). As plantas submetidas aos tratamentos de ceifa tiveram quantidade significativamente maior de raízes nos primeiros $10 \mathrm{~cm}$ do solo, mas não houve diferenças para as demais profundidades e nem para o perfil como um todo.

Nas condições do Norte e Noroeste do Paraná, na escolha do sistema de manejo de solo do pomar, deve-se atentar para o fato de que a região possui dois períodos climáticos bastante característicos: um seco e outro chuvoso, sendo importante, para cada época, a competição pela água do solo e o risco de erosão, respectivamente (Rufino et al., 1992). No Estado de São Paulo, em condições climáticas semelhantes, o sistema de cultivo mais empregado é de se usar roçadeira três a quatro vezes nas entrelinhas, durante o período chuvoso, e uma gradeação no período seco (Negri, 1988). Muitos citricultores, porém, intensificam o uso da grade de disco na entrelinha de plantio (Victoria Filho, 1988). Esse implemento é eficiente para o controle do mato nos pomares, pois realiza um trabalho agressivo, incorporando as ervas ao solo (Coelho, 1991). Entretanto, o excesso do uso da grade causa compactação do solo, redução da macroporosidade e da taxa de infiltração de água, aumentando o risco de erosão (Castro \& Lombardi Neto, 1992). O aumento da densidade do solo provoca concentração das raízes nas camadas mais superficiais do perfil, reduzindo a resistência das plantas a períodos de estiagem (Mazza et al., 1994; Moreira, 1983). Demattê \& Vitti (1992) recomendaram o controle de ervas daninhas sem o uso da grade e com associação de leguminosas para evitar a compactação e a redução da infiltração de água. $\mathrm{O}$ aumento da densidade do solo provoca também concentração das raízes nas camadas mais superficiais do perfil, reduzindo a resistência das plantas a períodos de estiagem (Mazza et al., 1994; Moreira, 1992). Para evitar danos ao sistema radicular, Moreira (1983) e Coelho (1991) alertaram para que se evitem gradagens no pomar a profundidades maiores que $5-7 \mathrm{~cm}$.

No presente trabalho avaliou-se o efeito de sistemas de manejo do solo, incluindo leguminosas recomendadas para os pomares do Estado do Paraná (Calegari, 
1995), no sistema radicular das plantas cítricas e características fisicas de um latossolo roxo em um pomar de tangerina 'Poncã', em Londrina, Paraná.

\section{4 Material e Métodos}

O clima da região, segundo a classificação de Köppen, é do tipo Cfa, subtropical úmido, com chuvas em todas as estações, podendo ocorrer seca no período de inverno (Corrêa et al., 1982). O pomar, formado por plantas de tangerina 'Poncã' (Citrus reticulata Blanco) enxertadas sobre limão 'Cravo' (Citrus limonia Osbeck.), localiza-se no campus da Universidade Estadual de Londrina, Paraná, em latossolo roxo distrófico (Rocha et al., 1991). A análise granulométrica apresentou $691 \mathrm{~g} \mathrm{~kg}^{-1}$ de argila, $216 \mathrm{~g} \mathrm{~kg}^{-1}$ de silte e $93 \mathrm{~g} \mathrm{~kg}^{-1}$ de areia. A análise química do solo (Empresa Brasileira de Pesquisa Agropecuária, 1979), realizada por ocasião da instalação do pomar revelou os seguintes valores para a camada de $0-15 \mathrm{~cm}$ : $\mathrm{pH}\left(\mathrm{H}_{2} \mathrm{O}\right)=5,38$; matéria orgânica $=29,2 \mathrm{~g} \mathrm{dm}^{-3} ; \mathrm{P}$ $\left(\right.$ Mehlich-1) $=2,04 \mathrm{mg} \mathrm{dm}^{-3} ; \mathrm{K}^{+}=2,3 \mathrm{mmol}_{\mathrm{c}} \mathrm{dm}^{-3} ; \mathrm{Ca}^{+2}=45 \mathrm{mmol}_{\mathrm{c}} \mathrm{dm}^{-3} ; \mathrm{Mg}^{+2}=19$ mmol $_{\mathrm{c}} \mathrm{dm}^{-3} ; \mathrm{H}^{+}+\mathrm{Al}^{3+}=70 \mathrm{mmol}_{\mathrm{c}} \mathrm{dm}^{-3}$. Para a camada de $15-30 \mathrm{~cm}$, os resultados foram: $\mathrm{pH}\left(\mathrm{H}_{2} \mathrm{O}\right)=5,02$; matéria orgânica $=17,5 \mathrm{~g} \mathrm{dm}^{-3} ; \mathrm{P}\left(\right.$ Mehlich-1) $=0,92 \mathrm{mg} \mathrm{dm}^{-3}$; $\mathrm{K}^{+}=1,1 \mathrm{mmol}_{\mathrm{c}} \mathrm{dm}^{-3} ; \mathrm{Ca}^{+2}=33 \mathrm{mmol}_{\mathrm{c}} \mathrm{dm}^{-3} ; \mathrm{Mg}^{+2}=32 \mathrm{mmol}_{\mathrm{c}} \mathrm{dm}^{-3} ; \mathrm{H}^{+}+\mathrm{Al}^{3+}=61$ $\mathrm{mmol}_{\mathrm{c}} \mathrm{dm}^{-3}$.

O experimento constou de cinco tratamentos de manejo de solo, nas entrelinhas das plantas cítricas, mantidos desde a sua instalação, em 1985/6: a): cobertura verde com a leguminosa perene Indigofera campestris Benth.; b): cobertura verde com a leguminosa perene Arachis prostrata Bong. ex Benth.; c): cobertura durante a época de chuvas com mucuna cinza - Stizolobium pruriens (leguminosa anual); d): uso alternado de uma gradagem a disco (em maio- junho, no início do período seco) e de roçadeira (três a quatro vezes no período de chuvas); e): capina manual o ano inteiro. $\mathrm{Na}$ linha de plantio o solo foi mantido permanentemente no limpo através de capina. Os tratamentos foram dispostos segundo delineamento experimental inteiramente ao acaso, com quatro repetições, duas plantas úteis por parcela, bordaduras simples, e cada parcela teve 234 
$\mathrm{m}^{2}$. Todos os tratamentos receberam calcário dolomítico a cada 3-4 anos e adubação mineral com base nos teores dos elementos no solo e nas produções médias anuais, de acordo com as recomendações do Grupo Paulista de Adubação e Calagem para Citros (1988).

Para o estudo das raízes utilizou-se o método da trincheira ou perfil (Bhöm, 1979), em novembro de 1996. Foram utilizadas três repetições (trincheiras) por tratamento, abertas perpendicularmente à linha de plantio, a $30 \mathrm{~cm}$ do tronco da árvore. Cada trincheira teve profundidade de $1,0 \mathrm{~m}$ e comprimento de $3,25 \mathrm{~m}$, a partir da linha de plantio até o meio da rua. A abertura inicial das trincheiras foi efetuada com retroescavadeira e o acabamento foi realizado manualmente com pá reta. As raízes visíveis foram cortadas rente à parede $\mathrm{e}$ as de maior diâmetro foram serradas. A seguir, as raizes foram expostas, com o auxilio de um escarificador em forma de rolo de madeira, munido de pregos de $1 \mathrm{~cm}$, sem cabeça. Para um maior contraste com o solo, as raízes foram coloridas com esmalte sintético "spray" branco, cujo excesso na parede do perfil foi retirado com faca. Foi afixada ao perfil uma moldura de madeira (Figura 1), nas dimensões da trincheira, dividida por fios de nylon em quadrículas de 25 por $25 \mathrm{~cm}$, totalizando 52 quadrículas por perfil (Cintra \& Neves, 1996). A quantidade de raízes expostas em cada quadrícula foi avaliada através de imagens obtidas com uma câmera de vídeo. As imagens foram digitalizadas por uma placa digitalizadora para IBM-PC, com resolução espacial igual a $512 \times 512$ pixels e 256 tons de cinza. Através do programa SIARCS/ EMBRAPA (Crestana et al., 1994), as imagens digitalizadas foram avaliadas para a determinação da área e comprimento das raizes em cada quadrícula (Figura 2). Os resultados da quantidade total e da quantidade de raízes presentes nas profundidades e a distâncias do tronco, segundo os tratamentos utilizados, foram analisados estatisticamente através da análise de variância, no delineamento inteiramente ao acaso, sendo os tratamentos dispostos num esquema fatorial (tipo de manejo $\mathrm{x}$ distância do tronco $\mathrm{x}$ profundidade).

Em cada uma das trincheiras abertas para a avaliação das raízes efetuou-se também o estudo das estruturas do solo através do método do perfil cultural 
(Gautronneau \& Manichon, 1987) adaptada por Tavares Filho et al. (1997). A descrição utilizada para a caracterização das estruturas encontra-se nas Tabelas 8 e 9.

Tabela 8: Modo de organização do perfil do solo (segundo Tavares Filho et al., 1997)*.

\begin{tabular}{|c|c|c|}
\hline $\begin{array}{l}\text { Níveis } \\
\text { de } \\
\text { análise }\end{array}$ & Simbologia & Definição \\
\hline \multirow[t]{2}{*}{ I } & $\begin{array}{l}\text { AM (alterado } \\
\text { pelo manejo) }\end{array}$ & Volume de solo onde é visível a interferência do homem \\
\hline & $\begin{array}{l}\text { NAM } \\
\text { (aparente - } \\
\text { mente não } \\
\text { alterado pelo } \\
\text { manejo) }\end{array}$ & $\begin{array}{l}\text { Volume de solo onde aparentemente não existe a interferência } \\
\text { do homem }\end{array}$ \\
\hline \multirow{3}{*}{$\begin{array}{c}\text { II } \\
(\mathrm{p} / \\
\text { volume } \\
\text { AM) }\end{array}$} & $\begin{array}{c}\mathrm{L} \\
\text { (livre) }\end{array}$ & $\begin{array}{l}\text { Volume de solo constituído por terra fina, solo pulverizado, } \\
\text { agregados de tamanhos variados (de } 0 \text { a } 10 \mathrm{~cm} \text { ) sem nenhuma } \\
\text { coesão. Comum na superficie dos solos trabalhados e/ou em } \\
\text { locais de atividade biológica. Pode apresentar raízes em grandes } \\
\text { quantidades, bem ramificadas e orientadas em todas as direções. } \\
\text { A estabilidade em água e a coesão a seco entre agregados deste } \\
\text { volume de solo são nulas, mas a estabilidade e a coesão dos } \\
\text { agregados pode ser alta. A porosidade a olho nu do volume } \\
\text { considerado é importante. }\end{array}$ \\
\hline & $\begin{array}{c}F \\
\text { (fissurado) }\end{array}$ & $\begin{array}{l}\text { Volume de solo onde um grande número de fissuras, que podem } \\
\text { ser em todas as direções, se fazem presentes, individualizando } \\
\text { torrões de tamanhos variados (maiores que } 5 \mathrm{~cm} \text { ). A porosidade } \\
\text { deste volume de solo é essencialmente fissural. }\end{array}$ \\
\hline & $\begin{array}{c}\text { C } \\
\text { (contínuo) }\end{array}$ & $\begin{array}{l}\text { Volume de solo onde os elementos do solo (agregados, torrões e } \\
\text { terra fina) estão unidos, formando um volume bastante } \\
\text { homogêneo, onde não é possível individualizar torrões a olho } \\
\text { nu. A porosidade neste volume é essencialmente de } \\
\text { empilhamento de agregados e/ou torrões, podendo apresentar } \\
\text { cavidades arredondadas e/ou poros tubulares. }\end{array}$ \\
\hline
\end{tabular}

* Analisado em no mínimo $50 \mathrm{~cm}$ horizontalmente no perfil de solo estudado. 
Tabela 9: Estado interno dos torrões presentes nos diferentes modos de organização do volume de solo antropizado (segundo Tavares Filho et al., 1997)*.

\begin{tabular}{|c|c|c|}
\hline $\begin{array}{l}\text { Nível } \\
\text { de } \\
\text { análise }\end{array}$ & $\begin{array}{c}\text { Simbo- } \\
\text { logia }\end{array}$ & Definição \\
\hline \multirow[t]{2}{*}{ III } & $\Delta \mu$ & $\begin{array}{l}\text { Estado interno dos torrões caracterizado por uma distribuição de } \\
\text { agregados com estrutura arredondada, com uma porosidade visível } \\
\text { a olho nu típica de empilhamento de agregados arredondados, } \\
\text { podendo existir fissuras. Apresenta raízes com orientação variada, } \\
\text { ramificadas e em forma não achatada. As faces de ruptura são } \\
\text { principalmente rugosas e a coesão a seco é elevada. }\end{array}$ \\
\hline & $\Delta$ & $\begin{array}{l}\text { Estado interno dos torrões caracterizado por uma distribuição de } \\
\text { agregados com estrutura angulosa (poliédrica, cúbica ou prismática) } \\
\text { ou laminar, devido à forte pressão externa, com uma porosidade } \\
\text { visível a olho nu pouco desenvolvida, com predominância de poros } \\
\text { tubulares e/ou cavidades arredondadas, podendo existir fissuras. } \\
\text { Quase não apresenta raízes e estas, quando presentes, possuem } \\
\text { poucas ramificações, são achatadas, com orientação vertical } \\
\text { prejudicada pela compactação. As faces de ruptura são } \\
\text { principalmente lisas e a coesão a seco é muito elevada. }\end{array}$ \\
\hline
\end{tabular}

* Nos modos de organização $\mathrm{L}$ e $\mathrm{F}$, além do estado interno dos torrões, deve-se classificá-los também pelo tamanho: pequenos $(1 \mathrm{a} 5 \mathrm{~cm})$, médios $(6$ a $10 \mathrm{~cm})$, grandes $(>10 \mathrm{~cm})$.

Para as avaliações das características fisicas elegeram-se os tratamentos Arachis prostata, roçadeira/grade e capina manual. A título de referência, foram também analisadas amostras do mesmo solo, com as mesmas profundidades, sob vegetação de mata natural e sob cultura anual (algodão no verão e aveia no inverno), localizados ao lado do pomar estudado. As determinações constaram de granulometria, pelo método de Boyoucos, densidade do solo, pelo método do anel volumétrico e de partículas, pelo método do balão volumétrico (Empresa Brasileira de Pesquisa Agropecuária, 1979) na ESALQ/USP. A partir dos resultados de densidade de solo e de partículas foi calculado o volume total de poros. As amostragens foram realizadas em três profundidades do solo (0-10 cm, 10-20 cm e 20-40 cm). Para a coleta das amostras foram feitas trincheiras de $50 \times 50 \times 50 \mathrm{~cm}$ no centro das ruas onde se encontravam os tratamentos e as amostras foram retiradas com anel volumétrico, em três repetições por tratamento. Coletaram-se 
a

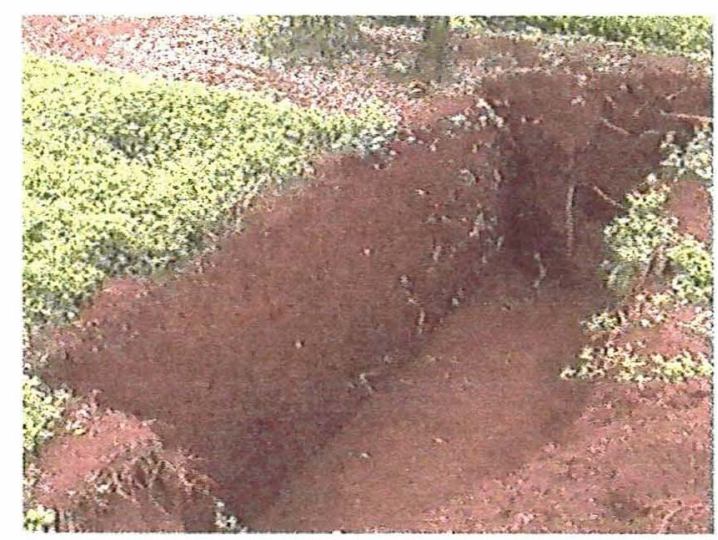

c

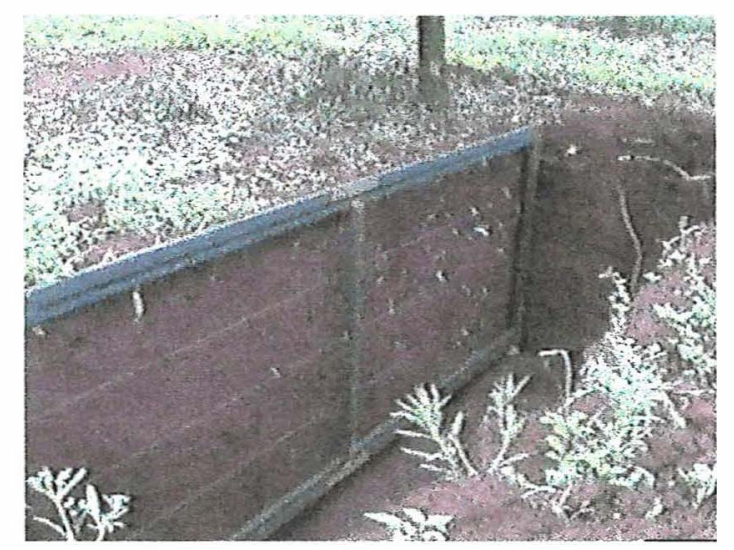

$\mathrm{b}$

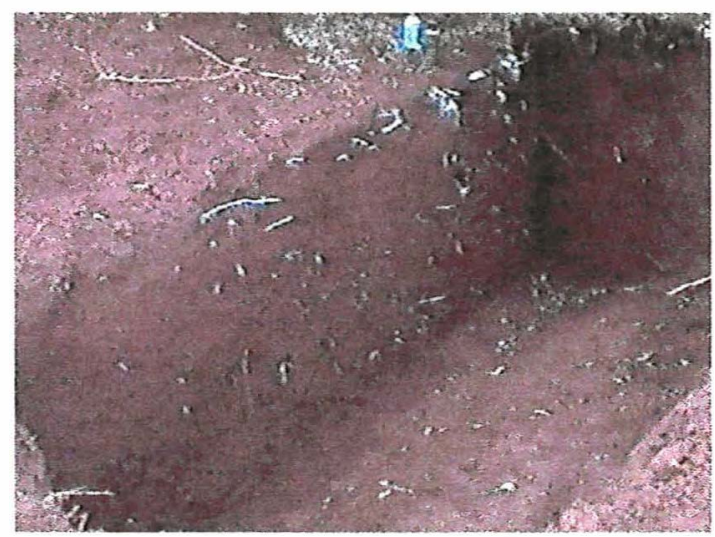

$\mathrm{d}$

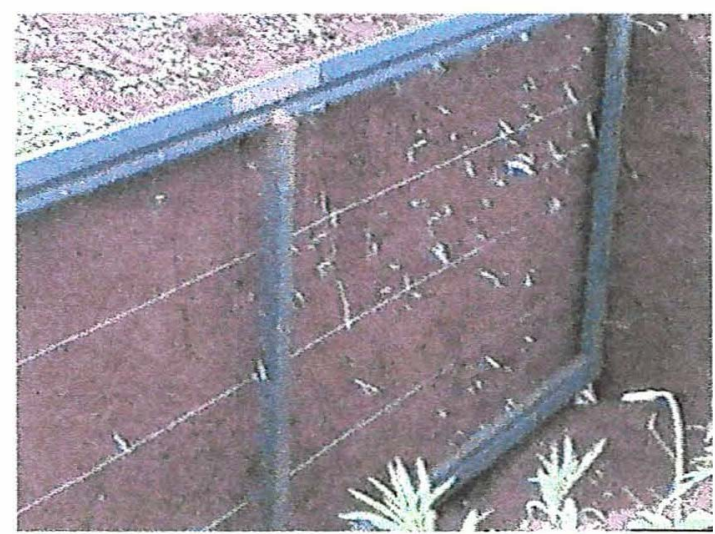

Figura 1. Trincheiras para avaliação do sistema radicular. a) Trincheira no tratamento Arachis prostrata; b) Trincheira no tratamento capina; c) Moldura para a filmagem; d) Detalhe da moldura com os fios de nylon para a filmagem. 
a

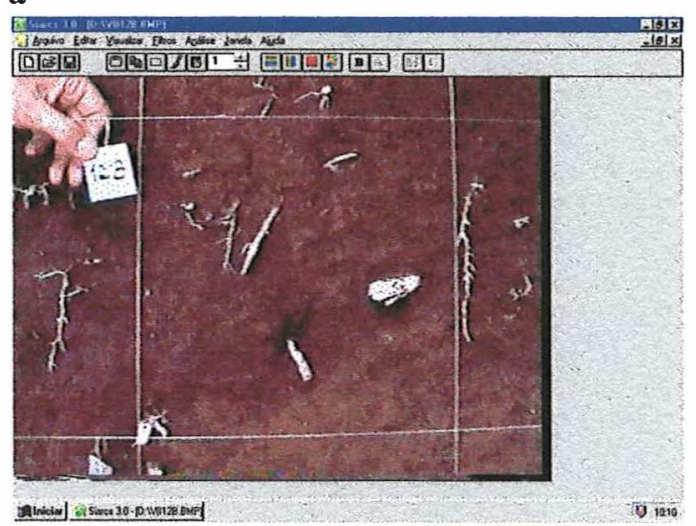

C

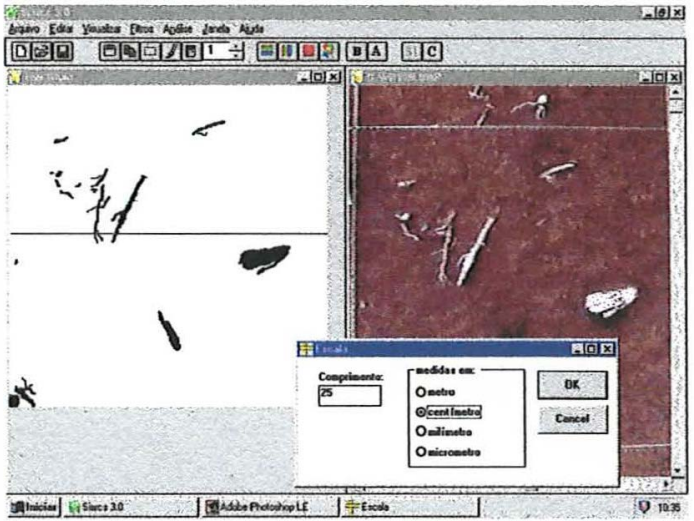

e

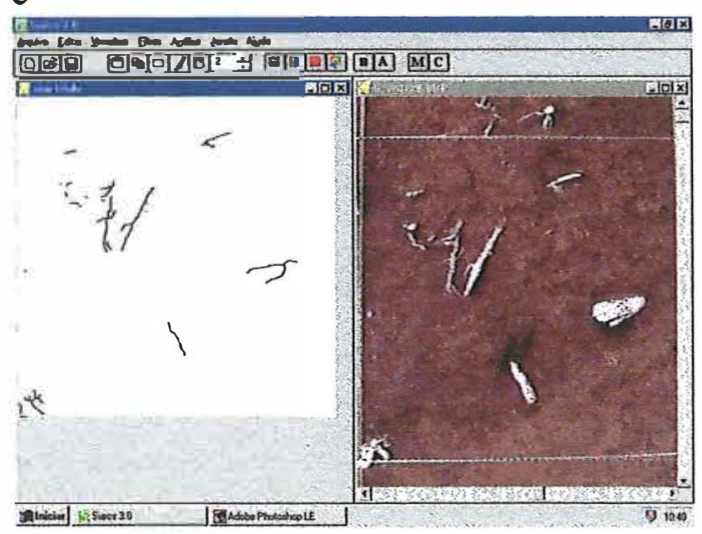

b

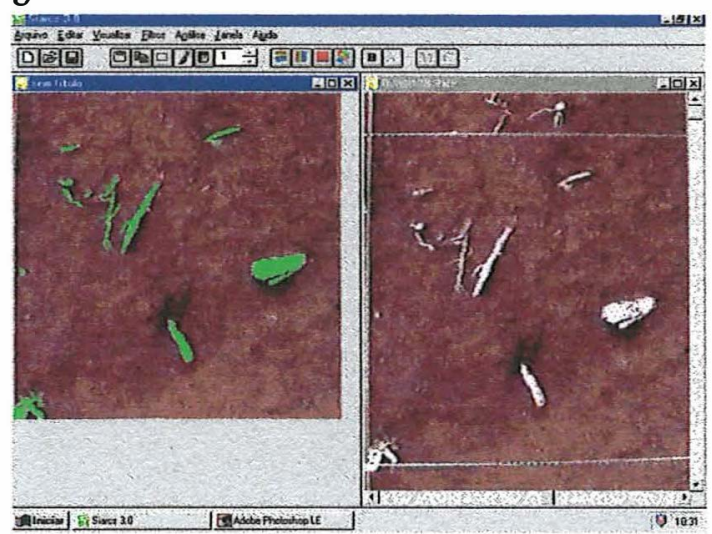

d

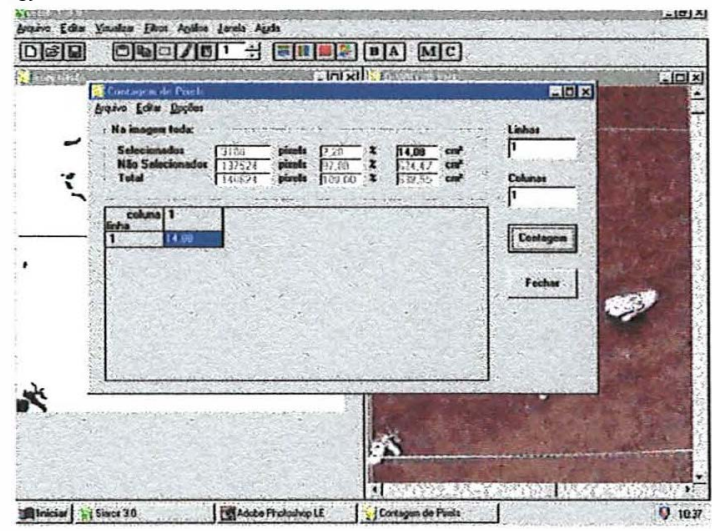

f

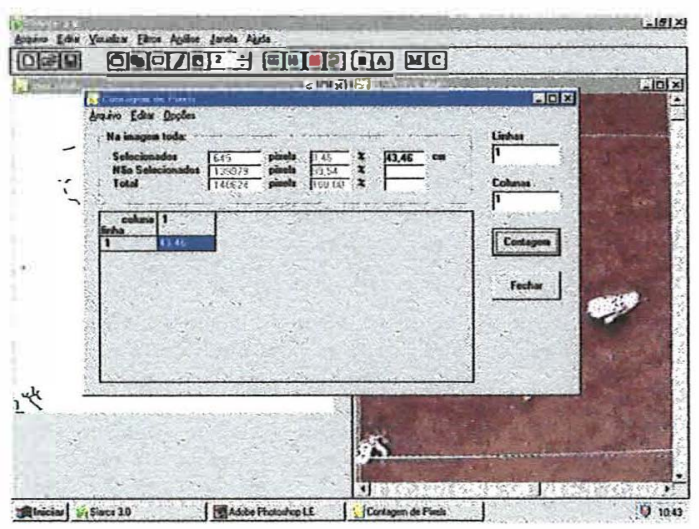

Figura 2. Avaliação do enraizamento através de imagens: a) imagem inicial; b) imagem colorida pelo Siarcs; c) binarização (preto e branco) e linha referencial com comprimento conhecido; d) determinação da área das raízes em preto; e) afinamento para determinação do comprimento; f) determinação do comprimento. 
também amostras das principais estruturas observadas nos perfis culturais, para a determinação da porosidade e da distribuição do tamanho dos poros, através do método da intrusão de mercúrio (Danielson \& Sutherland, 1986) com um porosímetro Micromeritics - 9310 (com pressão $10^{-3}$ a $206 \mathrm{Mpa}$ ) e da densidade do solo, pelo método do torrão parafinado, no CIRAD - Montpellier.

\section{5 Resultados e Discussão}

A análise de variância para a comparação entre as médias da quantidade total de raízes encontra-se na Tabela 37 do Anexo $B$. A avaliação do total de raízes visíveis no perfil, determinadas tanto pelo comprimento quanto pela área ocupada através do Siarcs, demonstrou que a quantidade de raizes não foi significativamente afetada (ao nível de 0,05 \% de significância) pelos sistemas de manejo de solo (Tabela 10). Essa ausência de

Tabela 10. Área média $\left(\mathrm{em}^{2} \mathrm{~cm}^{2}\right)$ e comprimento médio $(\mathrm{em} \mathrm{cm})$ do total das raízes de tangerina 'Poncã' enxertada sobre limão 'Cravo' visíveis nos perfis para os tratamento de manejo de solo (médias de três repetições).

\begin{tabular}{lcccc}
\hline & Área & & Comprimento \\
\cline { 1 - 2 } Tratamento & $\mathrm{cm}^{2}$ & & $\mathrm{~cm}$ \\
\hline I. compestris & $290,58 \mathrm{a}^{*}$ & & $1.329,22 \mathrm{a}$ \\
Mucuna cinza & $267,42 \mathrm{a}$ & & $1.097,89 \mathrm{a}$ \\
Roçadeira/Grade & $318,50 \mathrm{a}$ & & $1.284,31 \mathrm{a}$ \\
Capina & $385,45 \mathrm{a}$ & & $1.468,45 \mathrm{a}$ \\
\hline D.M.S. & 325,31 & & $1.738,65$ \\
C.V. $(\%)$ & 36,96 & & 46,22 \\
\hline
\end{tabular}

* Médias seguidas da mesma letra, na vertical, não diferem estatisticamente, pelo teste de Tukey, ao nível de $5 \%$ de significância. 
diferenças para a quantidade total de raízes diante de tratamentos de manejo do solo foi também observada nos citros por Frith (1952) e Martinez et al. (1970). Estes últimos observaram laranjeira 'Hamlin' enxertada sobre laranjeira 'Caipira' submetida a várias práticas de cultivo do solo, a saber: solo permanentemente limpo com grade de discos, herbicidas, mucuna preta na época chuvosa, "mulch" permanente, mato natural ceifado nas águas e gradeado na seca, soja perene, aração superficial e mato natural ceifado. Os autores utilizaram o método do trado e concluíram que o sistema radicular não apresentou diferença significativa em função dos tratamentos, até $50 \mathrm{~cm}$ de profundidade e $3 \mathrm{~m}$ do tronco.

Apesar da quantidade total de raízes ter sido considerada estatisticamente equivalente, observa-se (Tabela 10) que as diferenças entre as médias é grande, tendo os tratamentos $A$. prostrata e Capina apresentado as maiores quantidades e o tratamento Mucuna, as menores. Em função da alta variabilidade que este tipo de resultados normalmente apresenta, o coeficiente de variação aumenta, elevando a diferença mínima exigida para a significância. Atkinson (1980) apontou, como um dos problemas do estudo do sistema radicular das árvores, a grande variabilidade dos resultados, pois o meio onde as raízes crescem é muito heterogêneo e o sistema radicular consegue desviar de obstáculos e de zonas menos favoráveis ao crescimento. As raizes superam esses problemas mudando de forma e direção e seguindo caminhos de menor resistência deixados por fendas e canais abertos pela fauna do solo e por material orgânico em decomposição (Hamblin, 1985; Drew, 1990).

Investigou-se a possível diferença entre os tratamentos na distribuição das raizes no perfil, pois foram observadas diferenças no aspecto geral dos perfis durante o trabalho de campo. Para isso foi avaliada a distância horizontal máxima atingida pelas raízes a partir do tronco, segundo o quadro de análise de variância apresentado na Tabela 38 do Anexo B. As médias encontram-se na Figura 3, onde se observa que os tratamentos de manejo do solo afetaram de forma significativa a distância máxima atingida pelas raízes. $\mathrm{O}$ valor atingido foi significativamente menor nos tratamentos com 


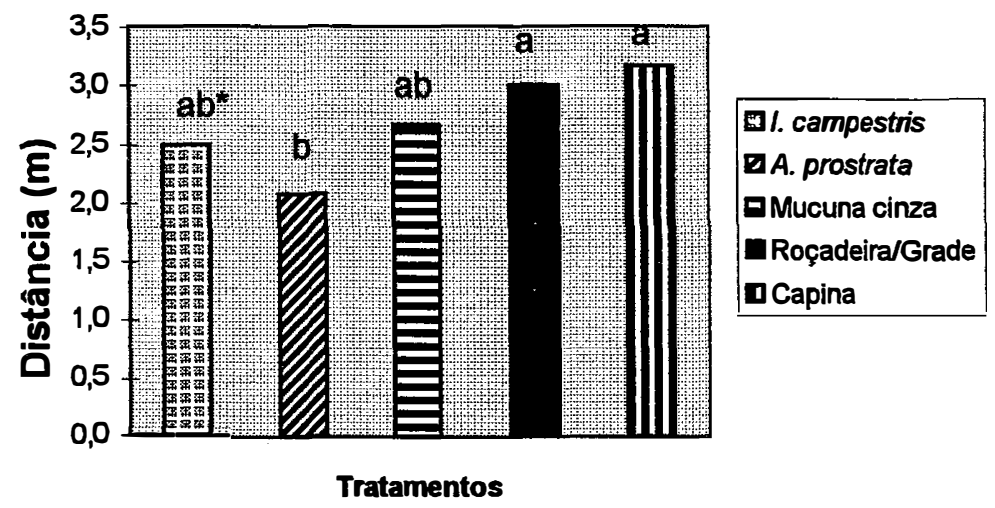

Figura 3. Distância máxima, a partir do tronco, atingida por raízes de tangerina 'Poncã' enxertada sobre limão 'Cravo' segundo os tratamentos de manejo de solo (média de três repetições). ${ }^{*}$ Letras iguais não diferem pelo teste de Tukey a 5 \% de significância.

leguminosas do que nos demais tratamentos. A menor distância foi observada com $A$. prostrata, chegando a $2,08 \mathrm{~m}$ do tronco. Por outro lado, a cobertura com a vegetação espontânea, provocada pelo uso da roçadeira, onde prevaleceram gramíneas, não diminuiu significativamente a distância alcançada pelas raizes, atingindo um valor de 3,0 $\mathrm{m}$, semelhante ao do tratamento Capina, que teve $3,17 \mathrm{~m}$. De forma geral, os valores encontrados, entre 2 e 3 metros, concordam com os de Pace \& Araujo (1986). Esses autores, ao estudarem a distribuição das raizes de laranja 'Natal' com seis anos de idade, sobre três porta-enxertos e com manejo do solo de roçadeira na época de chuvas e gradagem na seca., obtiveram para o limão 'Cravo' (mesmo porta-enxerto usado no presente trabalho) a distância de $2,50 \mathrm{~m}$, enquanto que os outros porta-enxertos atingiram valores de 2,10 m (Poncirus trifoliata) e 3,90 m (limão 'Volkameriano').

$\mathrm{Na}$ análise da distribuição das raízes nos perfis, os resultados da quantidade de raízes em cada quadrícula filmada foram analisados num esquema fatorial, sendo os fatores o manejo do solo, a distância do tronco e a profundidade. A análise de variância está representado na Tabela 39 do Anexo B. 
Para esta análise utilizaram-se apenas os resultados de comprimento de raízes e não os de área, pois de acordo com Weller (1971) a representação da quantidade de raízes através do comprimento dá uma idéia melhor, pois este, ao contrário da massa, expressa melhor a ocorrência das raizes finas, mais importantes na absorção de água e nutrientes. Na Tabela 11 encontram-se as médias obtidas para a densidade de raízes por quadrícula, em $\mathrm{cm} / 0,0625 \mathrm{~m}^{2}$, isolando-se o fator manejo. Observa-se que houve diferença entre os tratamentos, sendo que o uso de $A$. prostrata provocou a maior quantidade de raízes por quadrícula, que não diferiu significativamente do tratamento capina. Evidencia-se o efeito de concentração de raizes provocado por esta leguminosa, confirmando a observação feita sobre a distância do tronco.

Tabela 11. Densidade média por quadrícula $\left(\mathrm{em} \mathrm{cm} / 0,0625 \mathrm{~m}^{2}\right.$ ) das raízes de tangerina 'Poncã' enxertada sobre limão 'Cravo' em relação ao fator manejo de solo (médias de 156 observações).

\begin{tabular}{|c|c|}
\hline & Densidade \\
\hline Manejo do solo & $\mathrm{cm} / 0,0625 \mathrm{~m}^{2}$ \\
\hline I. campestris & $25,56 \mathrm{~b}$ \\
\hline A. prostrata & 35,12 a \\
\hline Mucuna cinza & $21,11 \mathrm{~b}$ \\
\hline Roçadeira/Grade & $24,70 \mathrm{~b}$ \\
\hline Capina & $28,23 \mathrm{ab}$ \\
\hline D.M.S. & 9,09 \\
\hline
\end{tabular}

* Médias seguidas da mesma letra, na vertical, não diferem estatisticamente, pelo teste de Tukey, ao nível de $5 \%$ de significância.

Isolando-se o fator profundidade, as médias obtidas para densidade das raizes $\left(\mathrm{em} \mathrm{cm} / 0,0625 \mathrm{~m}^{2}\right.$ ) por profundidade encontram-se na Tabela $12 \mathrm{e}$ Figura 4. Para as profundidades de $0,0-0,25 \mathrm{~m}$ e $0,25-0,50 \mathrm{~m}$ os sistemas de manejo estudados não provocaram diferenças na distribuição das raizes. Para as maiores profundidades $(0,50$ - 
Tabela 12. Densidade média das raízes das quadrículas $\left(\mathrm{em} \mathrm{cm} / 0,0625 \mathrm{~m}^{2}\right)$ observada para as profundidades de $0,0-0,25 ; 0,25-0,50 ; 0,50-0,75$ e $0,75-1,00 \mathrm{~m}$, em tangerina 'Poncã' enxertada sobre limão 'Cravo' submetida aos sistemas de manejo do solo (médias de 39 observações).

\begin{tabular}{lcccc}
\hline \multicolumn{5}{c}{ Profundidade $(\mathrm{m})$} \\
\hline \multicolumn{1}{c}{ Manejo do solo } & $0,0-0,25$ & $0,25-0,50$ & $0,50-0,75$ & $0,75-1,00$ \\
\hline I. campestris & $44,00 \mathrm{a}^{*}$ & $24,80 \mathrm{a}$ & $20,86 \mathrm{~b}$ & $12,58 \mathrm{~b}$ \\
A. prostrata & $35,24 \mathrm{a}$ & $31,04 \mathrm{a}$ & $41,40 \mathrm{a}$ & $32,79 \mathrm{a}$ \\
Mucuna cinza & $35,67 \mathrm{a}$ & $24,71 \mathrm{a}$ & $11,25 \mathrm{~b}$ & $12,82 \mathrm{~b}$ \\
Roçadeira./Grade & $39,04 \mathrm{a}$ & $27,41 \mathrm{a}$ & $19,71 \mathrm{~b}$ & $12,63 \mathrm{~b}$ \\
Capina & $51,72 \mathrm{a}$ & $20,15 \mathrm{a}$ & $25,16 \mathrm{ab}$ & $15,92 \mathrm{ab}$ \\
\hline D.M.S. & 18,19 & & \\
\hline
\end{tabular}

* Médias seguidas da mesma letra, em cada coluna, não diferem estatisticamente, pelo teste de Tukey, ao nível de $5 \%$ de significância.

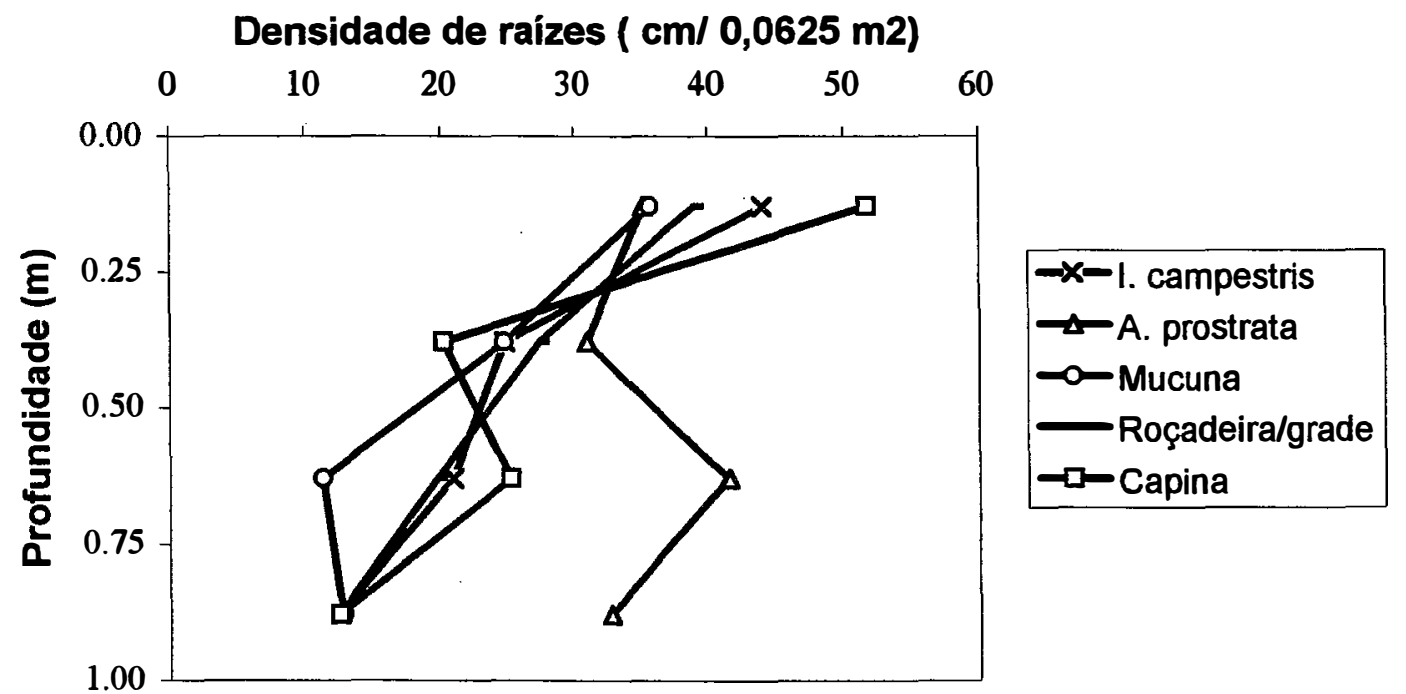

Figura 4. Distribuição das raízes de tangerina 'Poncã' enxertada em limão 'Cravo', em densidade de raízes $\left(\mathrm{cm} / 0,0625 \mathrm{~m}^{2}\right)$, segundo o manejo do solo e nas profundidades de $0-0,25 ; 0,25-0,50 ; 0,50-0,75$ e $0,75-1,00 \mathrm{~m}$ (médias de 39 observações). 
0,75 m e 0,75-1,00 m) o uso de $A$. prostrata provocou um aprofundamento do sistema radicular, com diferenças significativas em relação aos demais tratamentos, exceto o de capina, que teve um comportamento intermediário. Considerando os resultados relacionados a este adubo verde, com a menor distância horizontal (Figura 3), estes resultados podem ser interpretados como um crescimento compensatório. Através dele, a parte do sistema radicular que se encontra em um ambiente mais favorável apresenta um crescimento maior do que teria se o sistema como um todo estivesse em condições satisfatórias, enquanto que a parte que se acha em ambiente desfavorável tem um crescimento menor (Russel, 1981). Dessa maneira, como resposta à restrição horizontal, provavelmente provocada pelo intenso enraizamento de $A$. prostrata, o sistema radicular das plantas estudadas aumentou seu crescimento em profundidade. Este mecanismo ocorre através de relação fonte-dreno e da ação de hormônio inibidores do crescimento (Russel, 1981; Drew, 1990). O crescimento compensatório em raízes de citros foi observado em experimentos de densidade de plantio por Kauffinan et al. (1972) na Califórnia e por Castle (1980) na Flórida. Este último observou, com o método do trado, a distribuição do sistema radicular de laranja 'Pineapple' enxertada sobre limão 'Rugoso' em três espaçamentos de plantio em solo arenoso. As raízes se apresentavam em maior concentração e se aprofundavam mais nos plantios mais adensados, compensando assim a menor área de solo disponível. Plantas com sistemas radiculares mais profundos têm melhores condições de atravessar períodos de "stress" hídrico, diminuindo as perdas de produção (Mazza et al., 1994; Pearson, 1971).

A diferença de distribuição de raízes em função da cobertura vegetal foi também observada em pessegueiro, pelo método da trincheira, por Parker et al. (1993) e Parker \& Meyer (1996). Esses autores utilizaram seis tipos de manejo do solo, com diferentes espécies de cobertura vegetal e concluíram que existem espécies que são muito pouco competitivas, possibilitando às árvores um enraizamento tão abundante quanto o do solo mantido permanentemente sem vegetação através de herbicida. Os autores 
enfatizaram a necessidade de intensificar os estudos de identificação, seleção e tipo de manejo necessário para estas plantas de cobertura.

Ao contrário do observado no presente trabalho, Frith (1952) teve efeito do manejo do solo apenas para a profundidade de 0 a $10 \mathrm{~cm}$, num pomar cítrico na Austrália, em um experimento fatorial com quatro tipos de manejo do solo, quatro níveis

Tabela 13. Densidade média (em $\mathrm{cm} / 0,0625 \mathrm{~m}^{2}$ ) das raízes observadas nas quadrículas para as distâncias do tronco de $0,0-0,25 ; 0,25-0,50 ; 0,50-0,75 ; 0,75-1,00$; $1,00-1,25 ; 1,25-1,50 ; 1,50-1,75 ; 1,75-2,00 ; 2,00-2,25 ; 2,25-2,50 ; 2,50-2,75$; 2,75-3,00 e 3,00-3,25 m, em tangerina 'Poncã' enxertada sobre limão 'Cravo' submetida a sistemas de manejo do solo (médias de 12 observações).

\begin{tabular}{lccccc}
\hline \multicolumn{5}{c}{ Manejo do solo } \\
\hline $\begin{array}{l}\text { Distância } \\
\text { do tronco (m) }\end{array}$ & I. campestris & A. prostrata & Mucuna cinza & $\begin{array}{c}\text { Roçadeira/ } \\
\text { Grade }\end{array}$ & Capina \\
\hline \multicolumn{5}{c}{ Densidade de raízes $\left(\mathrm{cm} / 0,0625 \mathrm{~m}^{2}\right)$} \\
\hline $0,0-0,25$ & $46,74 \mathrm{~b}^{*}$ & $81,51 \mathrm{a}$ & $33,57 \mathrm{~b}$ & $55,99 \mathrm{ab}$ & $40,16 \mathrm{~b}$ \\
$0,25-0,50$ & $46,46 \mathrm{~b}$ & $91,92 \mathrm{a}$ & $38,82 \mathrm{~b}$ & $61,28 \mathrm{ab}$ & $42,63 \mathrm{~b}$ \\
$0,50-0,75$ & $54,08 \mathrm{ab}$ & $79,81 \mathrm{a}$ & $36,86 \mathrm{~b}$ & $43,15 \mathrm{~b}$ & $44,82 \mathrm{~b}$ \\
$0,75-1,00$ & $71,08 \mathrm{a}$ & $44,77 \mathrm{abc}$ & $36,39 \mathrm{bc}$ & $28,04 \mathrm{c}$ & $63,53 \mathrm{ab}$ \\
$1,00-1,25$ & $33,37 \mathrm{a}$ & $46.07 \mathrm{a}$ & $16,74 \mathrm{a}$ & $17,19 \mathrm{a}$ & $29,40 \mathrm{a}$ \\
$1,25-1,50$ & $27,96 \mathrm{a}$ & $50,6 \mathrm{a}$ & $22,05 \mathrm{a}$ & $29,33 \mathrm{a}$ & $21,98 \mathrm{a}$ \\
$1,50-1,75$ & $9,03 \mathrm{a}$ & $36,15 \mathrm{a}$ & $23,28 \mathrm{a}$ & $10,49 \mathrm{a}$ & $20,69 \mathrm{a}$ \\
$1,75-2,00$ & $11,57 \mathrm{a}$ & $17,16 \mathrm{a}$ & $15,58 \mathrm{a}$ & $27,33 \mathrm{a}$ & $21,8 \mathrm{a}$ \\
$2,00-2,25$ & $11,32 \mathrm{a}$ & $8,56 \mathrm{a}$ & $15,80 \mathrm{a}$ & $28,89 \mathrm{a}$ & $21,75 \mathrm{a}$ \\
$2,25-2,50$ & $8,41 \mathrm{a}$ & $0,00 \mathrm{a}$ & $11,46 \mathrm{a}$ & $3,68 \mathrm{a}$ & $19,67 \mathrm{a}$ \\
$2,50-2,75$ & $10,35 \mathrm{a}$ & $0,00 \mathrm{a}$ & $14,19 \mathrm{a}$ & $3,50 \mathrm{a}$ & $17,60 \mathrm{a}$ \\
$2,75-3,00$ & $1,92 \mathrm{a}$ & $0,00 \mathrm{a}$ & $4,26 \mathrm{a}$ & $6,26 \mathrm{a}$ & $13,21 \mathrm{a}$ \\
$3,00-3,25$ & $0,00 \mathrm{a}$ & $0,00 \mathrm{a}$ & $5,48 \mathrm{a}$ & $5,94 \mathrm{a}$ & $9,88 \mathrm{a}$ \\
\hline D.M.S. & 32,80 & & & \\
\hline
\end{tabular}

* Médias seguidas da mesma letra, na horizontal, não diferem estatisticamente, pelo teste de Tukey, ao nível de $5 \%$ de significância. 


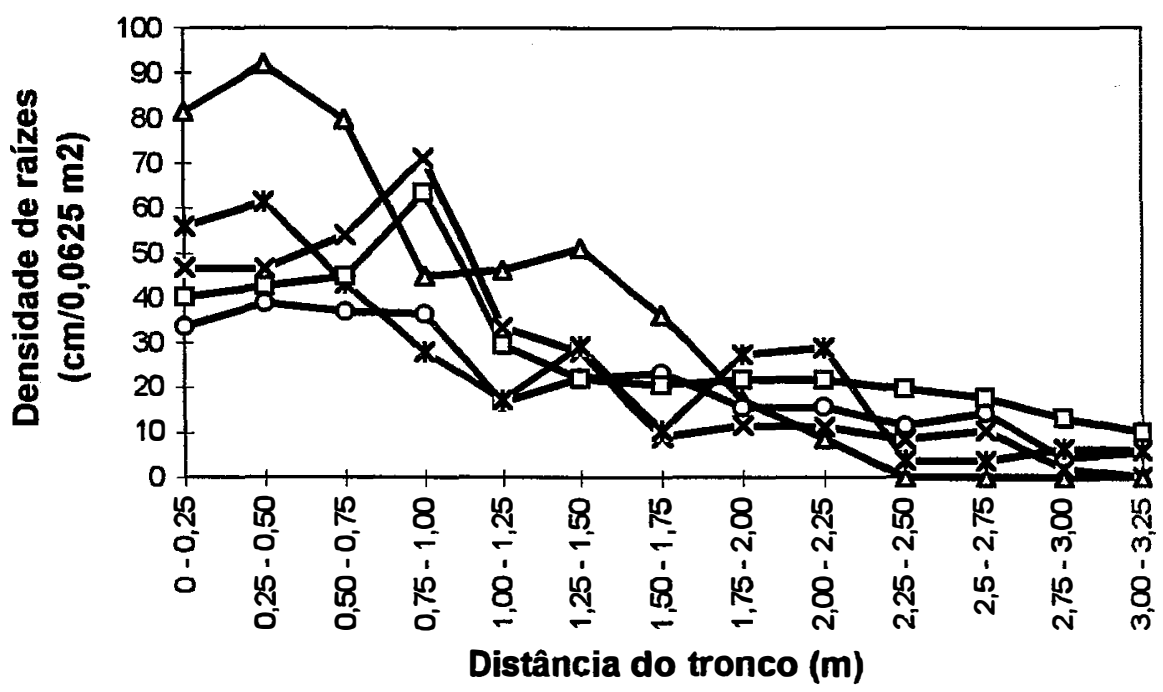

$-x-$ I. campestris $-\Delta-$ A. prostrata $-0-$ Mucuna cinza $\rightarrow x-$ Roçad./Grade $-\square-$ Capina

Figura 5. Densidade $\left(\mathrm{cm} / 0,0625 \mathrm{~m}^{2}\right)$ de raízes de tangerina 'Poncã' enxertada em limão 'Cravo' observadas nas quadrículas, para os sistemas de manejo do solo e nas distâncias do tronco de 0-0,25;0,25-0,50;0,50-0,75;0,75-1,00; 1,00-1,25; $1,25-1,50 ; 1,50-1,75$ e $1,75-2,00 ; 2,00-2,25 ; 2,25-2,50 ; 2,50-2,75 ; 2,75-3,00$ e 3,00-3,25 m (médias de 12 observações).

de adubação nitrogenada, quatro níveis de irrigação e quatro combinações enxerto/portaenxerto. Os tipos de manejo testados foram: cultivo mecânico no verão e adubo verde no inverno, o mesmo tratamento mais esterco de curral, vegetação natural ceifada, e herbicida (querosene). As plantas submetidas aos tratamentos de ceifa tiveram quantidade significativamente maior de raízes nos primeiros $10 \mathrm{~cm}$ do solo, mas não houve diferenças para as demais profundidades e nem para o perfil como um todo.

Quanto à distribuição em relação à distância do tronco (Tabela 13 e Figura 5) o manejo do solo com $A$. prostrata diferiu dos demais nas três menores distâncias do tronco, tendo maior concentração de raízes até a distância de $0,75 \mathrm{~m}$ do tronco. A partir desta distância, e até a distância de 1,75 do tronco, este sistema de manejo continuou 
apresentando quantidades maiores de raízes, embora não diferentes estatisticamente. Esta quantidade superior de raizes, entretanto, cessa abruptamente a partir da distância de $2,25 \mathrm{~m}$, quando então passa a não apresentar raiz alguma até o meio da rua $(3,25 \mathrm{~m})$. Observações visuais das trincheiras indicaram que esta interrupção brusca da presença das raízes das plantas cítricas coincide com o início da presença do sistema radicular da cobertura vegetal, $A$. prostrata, que é muito abundante e vigoroso.

Na Tabela 14 e Figuras 6 e 7 encontram-se os resultados da distribuição das raízes por profundidade em termos de porcentagem do total avaliado e porcentagem acumulada. Para quatro dos cinco sistemas de manejo, a maior parte do sistema radicular (de 60 a $70 \%$ ) situou-se na profundidade de até $0,50 \mathrm{~m}$. 0 tratamento com $A$. prostrata, entretanto, apresentou um padrão diferenciado. $\mathrm{O}$ uso desta leguminosa aprofundou o sistema radicular das plantas, que a $0,50 \mathrm{~m}$ de profundidade apresentaram $47,2 \%$ do total, atingindo $76,7 \%$ das raízes à distância de $0,75 \mathrm{~m}$.

Tabela 14. Porcentagem (\%) e porcentagem acumulada (\%) por profundidade do total da densidade de raizes observado para as profundidades de $0,0-0,25 ; 0,25-0,50$; 0,50-0,75 e 0,75-1,00 m, em tangerina 'Poncã' enxertada sobre limão 'Cravo' submetida a sistemas de manejo do solo (médias de 39 observações).

\begin{tabular}{cccccc}
\hline \multicolumn{6}{c}{ Manejo do solo } \\
\hline $\begin{array}{c}\text { Produndidade } \\
(\mathrm{m})\end{array}$ & I. campestris & A. prostrata & Mucuna cinza & $\begin{array}{c}\text { Roçadeira/ } \\
\text { Grade }\end{array}$ & Capina \\
\hline \multicolumn{5}{c}{$\%$ de raízes - \% acumulada } \\
\hline $0,0-0,25$ & $43,0-43,0$ & $25,1-25,1$ & $42,2-42,2$ & $39,5-39,5$ & $45,8-45,8$ \\
$0,25-0,50$ & $24,3-67,3$ & $22,1-47,2$ & $29,3-71,5$ & $27,7-67,2$ & $17,8-63,6$ \\
$0,50-0,75$ & $20,4-87,7$ & $29,5-76,7$ & $13,3-84,8$ & $20,0-87,2$ & $22,3-85,9$ \\
$0,75-1,00$ & $12,3-100,0$ & $23,3-100,0$ & $15,2-100,0$ & $12,8-100,0$ & $14,1-100,0$ \\
\hline
\end{tabular}




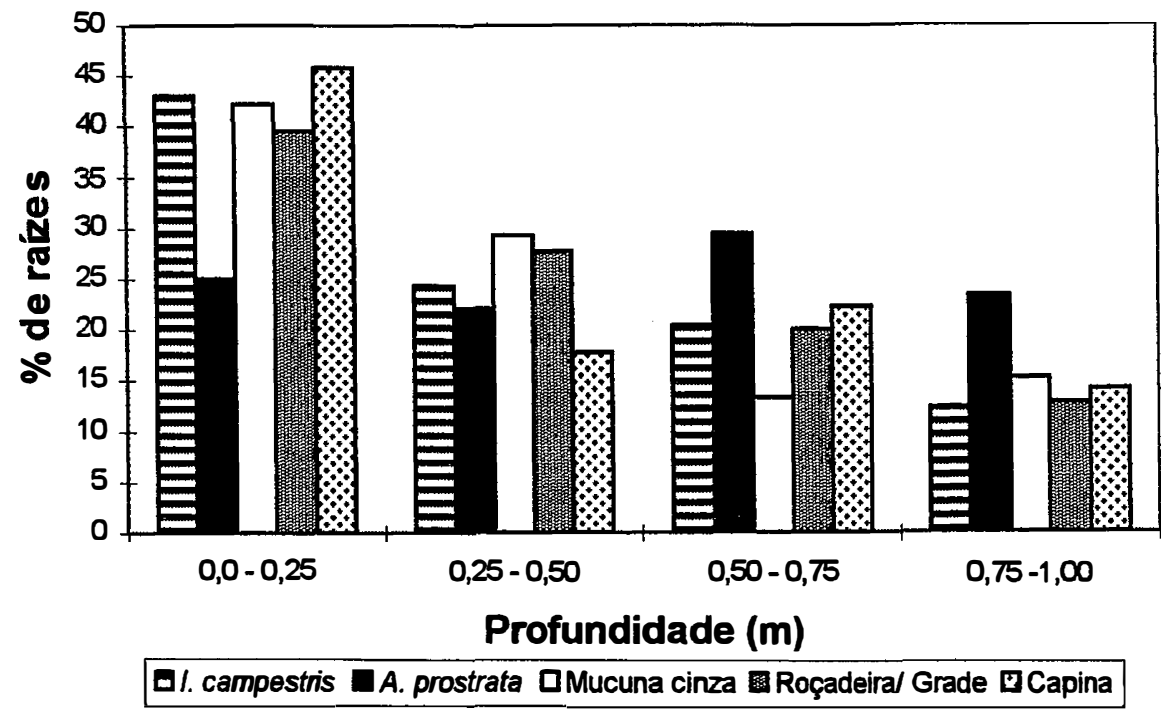

Figura 6. Porcentagem (\%) por profundidade do total da densidade de raízes de tangerina 'Poncã' enxertada sobre limão 'Cravo' submetida a sistemas de manejo do solo (médias de 39 observações).

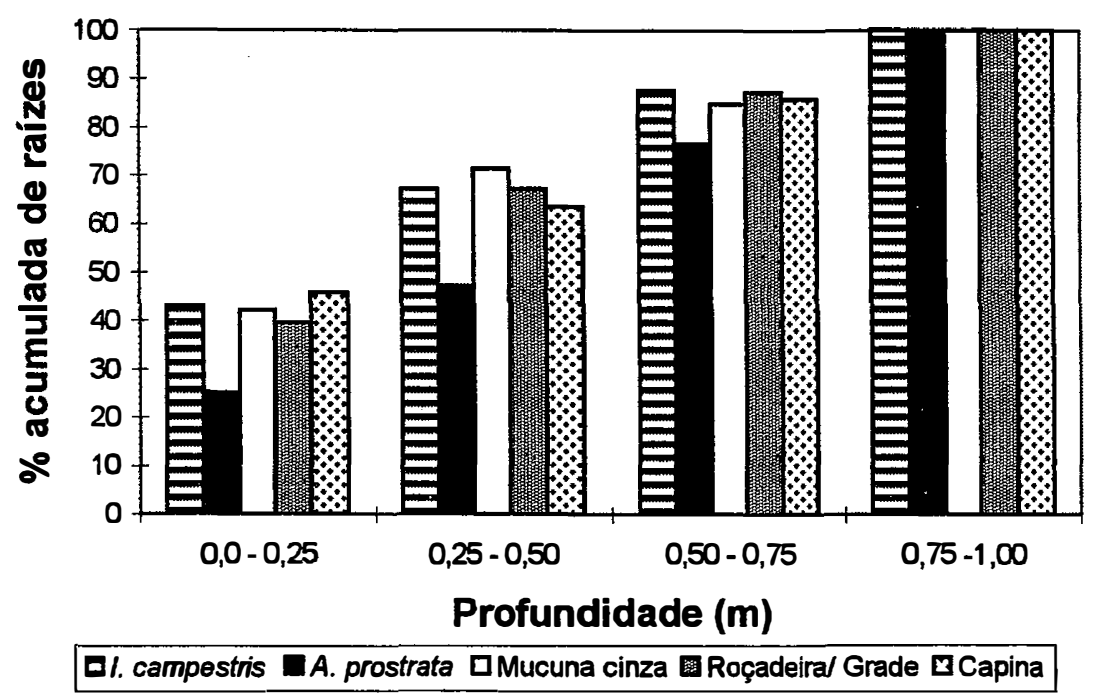

Figura 7. Porcentagem acumulada (\%), por profundidade, do total do densidade de raízes de tangerina 'Poncã' enxertada sobre limão 'Cravo' submetida a sistemas de manejo do solo (médias de 39 observações). 
Para a distribuição de raízes por distância do tronco em porcentagem do total avaliado (Tabela 15 e Figuras 8 e 9), observam-se também dois padrões distintos. Neste caso, tanto o uso de $A$. prostrata, como de $I$. campestris restringiram o sistema radicular, que apresentou $60-70 \%$ do total até $1,0 \mathrm{~m}$ de distância, enquanto que nos demais sistemas a mesma percentagem foi atingida a $1,5 \mathrm{~m}$ de distância.

Tabela 15. Porcentagem (\%) e porcentagem acumulada (\%), por distância, da densidade de raízes observada para as distâncias do tronco de $0-0,25 ; 0,25-0,50 ; 0,50-$ 0,$75 ; 0,75-1,00 ; 1,00-1,25 ; 1,25-1,50 ; 1,50-1,75$ e $1,75-2,00 ; 2,00-2,25 ; 2,25-$ 2,$50 ; 2,50-2,75 ; 2,75-3,00$ e 3,00-3,25 m, em tangerina 'Poncã' enxertada sobre limão 'Cravo' submetida a sistemas de manejo do solo (médias de 12 observações).

\begin{tabular}{|c|c|c|c|c|c|}
\hline \multirow[b]{2}{*}{$\begin{array}{l}\text { Distância } \\
\text { do tronco (m) }\end{array}$} & \multicolumn{5}{|c|}{ Manejo do solo } \\
\hline & I. campestris & A. prostrata & Mucuna cinza & $\begin{array}{l}\text { Roçadeira/ } \\
\text { Grade }\end{array}$ & Capina \\
\hline & \multicolumn{5}{|c|}{$\%$ de raízes - $\%$ acumulada } \\
\hline $0,0-0,25$ & $14,1-14,1$ & $17,9-17,9$ & $12,2-12,0$ & $17,4-17,4$ & $10,9-10,9$ \\
\hline $0,25-0,50$ & $14,0-28,1$ & $20,1-38,0$ & $14,1-26,3$ & $19,1-36,5$ & $11,6-22,5$ \\
\hline $0,50-0,75$ & $16,3-44,4$ & $17,5-55,5$ & $13,4-39,7$ & $13,4-49,9$ & $12,2-34,7$ \\
\hline $0,75-1,00$ & $21,4-65,8$ & $9,8-65,3$ & $13,2-52,9$ & $8,7-58,6$ & $17,3-52,0$ \\
\hline $1,00-1,25$ & $10,0-75,8$ & $10,1-75,4$ & $6,1-59,0$ & $5,4-64,0$ & $8,0-60,0$ \\
\hline $1,25-1,50$ & $8,4-84,2$ & $11,1-86,5$ & $8,0-67,0$ & $9,1-73,1$ & $6,0-66,0$ \\
\hline $1,50-1,75$ & $2,7-86,9$ & $7,9-94,4$ & $8,5-75,5$ & $3,3-76,4$ & $5,7-71,7$ \\
\hline $1,75-2,00$ & $3,5-90,4$ & $3,7-98,1$ & $5,7-81,2$ & $8,5-84,9$ & $5,9-77,6$ \\
\hline $2,00-2,25$ & $3,4-93,8$ & $1,9-100 ; 0$ & $5,8-87,0$ & $9,0-93,9$ & $5,9-83,5$ \\
\hline $2,25-2,50$ & $2,5-96,3$ & $0,0-100,0$ & $4,2-91,2$ & $1,1-95,0$ & $5,4-88,9$ \\
\hline $2,50-2,75$ & $3,1-99,4$ & $0,0-100,0$ & $5,2-96,4$ & $1,1-96,1$ & $4,8-93,7$ \\
\hline $2,75-3,00$ & $0,6-100,0$ & $0,0-100,0$ & $1,6-98,0$ & $2,0-98,1$ & $3,6-97,3$ \\
\hline $3,00-3,25$ & $0,0-100,0$ & $0,0-100,0$ & $2,0-100,0$ & $1,9-100,0$ & $2,7-100,0$ \\
\hline
\end{tabular}




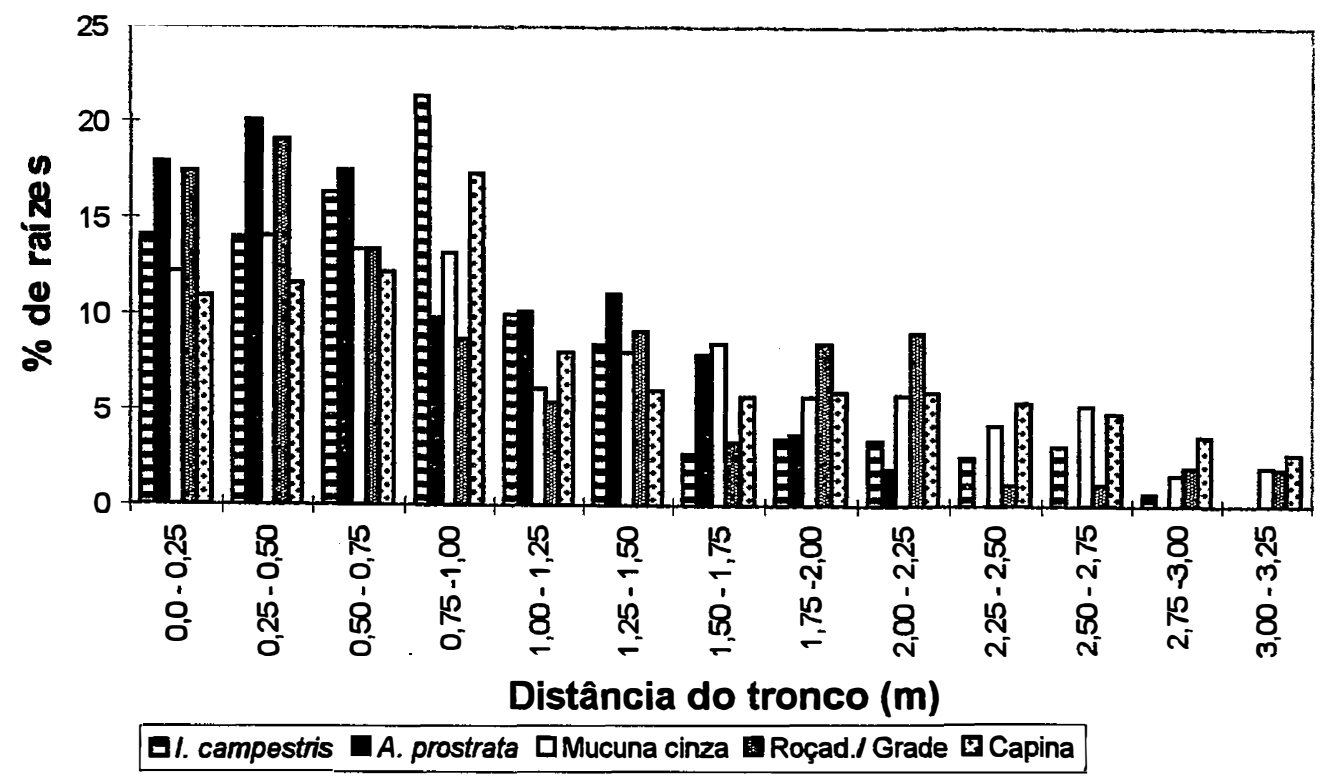

Figura 8. Porcentagem (\%) por distância do tronco da densidade de raízes de tangerina 'Poncã' enxertada sobre limão 'Cravo' submetida a sistemas de manejo do solo (médias de 12 observações).

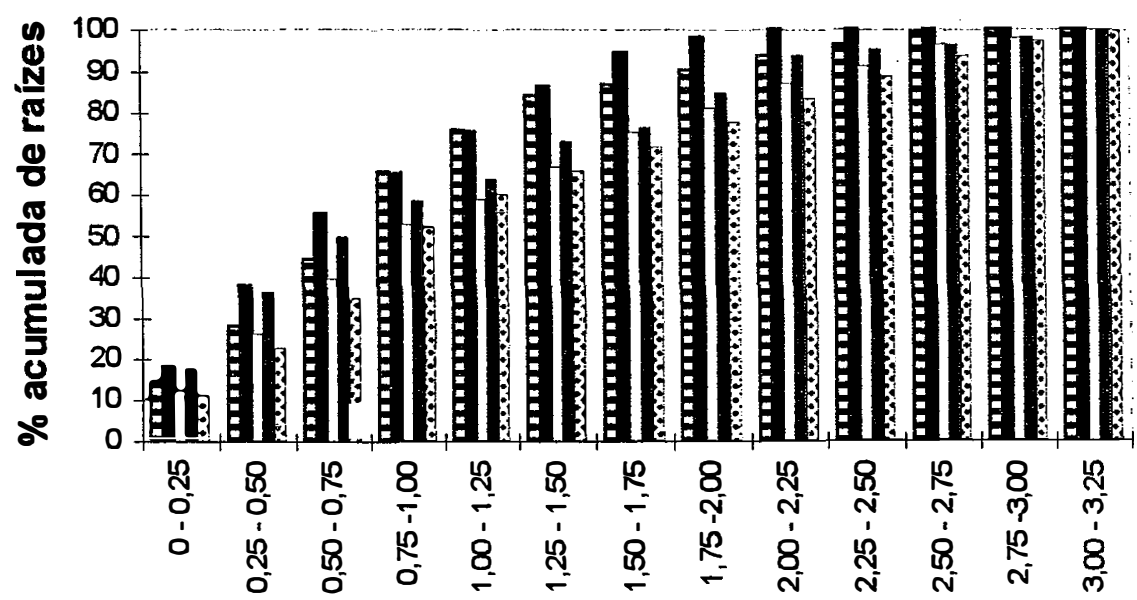

Distância do tronco $(m)$

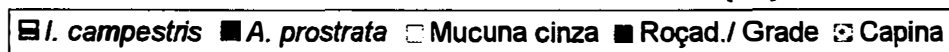

Figura 9. Porcentagem acumulada (\%) por distância do tronco da densidade de raízes de tangerina 'Poncã' enxertada sobre limão 'Cravo' submetida a sistemas de manejo do solo (médias de 12 observações). 
Em relação às condições fisicas do solo, a análise da variância para os resultados de densidade e porosidade do solo do pomar (amostrados por profundidade, com anel volumétrico) encontram-se na Tabela 40 do Anexo B e as médias estão

Tabela 16. Densidade do solo e de partículas para os tratamentos de manejo de solo do pomar e profundidades do solo (amostragem por profundidade, com anel volumétrico).

\begin{tabular}{|c|c|c|c|}
\hline \multirow[t]{2}{*}{ Tratamento } & \multicolumn{2}{|c|}{$\begin{array}{c}\text { Densidade } \\
\mathrm{kg} \mathrm{dm}^{-3}\end{array}$} & \multirow{2}{*}{$\begin{array}{l}\text { Volume total } \\
\text { de poros }\end{array}$} \\
\hline & Solo & Partic. & \\
\hline \multicolumn{4}{|c|}{$0-10 \mathrm{~cm}$} \\
\hline A. prostrata & $1,22 a^{*}$ & 2,80 & $0,564 \mathrm{a}$ \\
\hline Roçadeira/Grade & $1,26 \mathrm{a}$ & 2,76 & $0,545 \mathrm{a}$ \\
\hline Capina & $1,21 \mathrm{a}$ & 2,83 & $0,572 \mathrm{a}$ \\
\hline D.M.S. & 0,11421 & - & 0,04344 \\
\hline C.V. (\%) & 3,740 & - & 3,073 \\
\hline \multicolumn{4}{|c|}{$10-20 \mathrm{~cm}$} \\
\hline A. prostrata & $1,25 \mathrm{a}$ & 2,84 & $0,558 \mathrm{a}$ \\
\hline Roçadeira/Grade & $1,21 \mathrm{a}$ & 2,88 & $0,578 \mathrm{a}$ \\
\hline Capina & $1,22 \mathrm{a}$ & 2,86 & $0,575 \mathrm{a}$ \\
\hline D.M.S. & 0,13233 & - & 0,051 \\
\hline C.V. (\%) & 4,329 & - & 3,537 \\
\hline \multicolumn{4}{|c|}{$20-40 \mathrm{~cm}$} \\
\hline A. prostrata & $1,10 \mathrm{a}$ & 2,80 & $0,605 \mathrm{a}$ \\
\hline Roçadeira/Grade & $1,04 \mathrm{a}$ & 2,90 & $0,639 a$ \\
\hline Capina & $1,10 \mathrm{a}$ & 2,85 & $0,613 \mathrm{a}$ \\
\hline D.M.S. & 0,08055 & - & 0,03465 \\
\hline C.V. (\%) & 2,976 & - & 2,226 \\
\hline
\end{tabular}

* Médias seguidas da mesma letra em cada coluna, para cada profundidade, não diferem entre si ao nível de $5 \%$ de significância pelo teste de Tukey 
Tabela 17. Densidade do solo e de partículas e porosidade total para cultura anual e mata natural nas profundidades do solo de 0-10, 10-20 e 20-40 cm.

\begin{tabular}{|c|c|c|c|}
\hline \multirow[t]{2}{*}{ Situação } & \multicolumn{2}{|c|}{$\begin{array}{c}\text { Densidade } \\
\mathrm{kg} \mathrm{dm}^{-3}\end{array}$} & \multirow{2}{*}{$\begin{array}{l}\text { Volume total } \\
\text { de poros } \\
\mathrm{dm}^{3} \mathrm{dm}^{-3}\end{array}$} \\
\hline & Solo & Partic & \\
\hline \multicolumn{4}{|c|}{$0-10 \mathrm{~cm}$} \\
\hline Cultura anual & 1,02 & 2,73 & 0,627 \\
\hline Mata nativa & 0,85 & 2,75 & 0,693 \\
\hline \multicolumn{4}{|c|}{$10-20 \mathrm{~cm}$} \\
\hline Cultura anual & 1,18 & 2,77 & 0,571 \\
\hline Mata nativa & 0,95 & 2,86 & 0,667 \\
\hline \multicolumn{4}{|c|}{$20-40 \mathrm{~cm}$} \\
\hline Cultura anual & 1,15 & 2,84 & 0,595 \\
\hline Mata nativa & 1,00 & 2,86 & 0,650 \\
\hline
\end{tabular}

apresentadas na Tabela 16. Os dados de densidade e porosidade do solo (amostrados por profundidade, com anel volumétrico) para as situações de mata nativa e cultura anual são apresentados na Tabela 17. Na Tabela 18 encontram-se os dados de densidade de solo e partículas e de porosidade total e por tamanho de poros, determinadas por estrutura em amostras de torrão indeformado, tanto para os tratamentos do pomar quanto para as situações de referência (cultura anual e mata nativa).

O perfil cultural de referência (Figura 10), realizado sob vegetação de mata, revelou três volumes diferenciados quanto à estrutura. Próximo à superficie observou-se o estado L (livre), com terra fina e pequenos agregados sem coesão, com abundante presença de raízes. A partir daí e até $70-80 \mathrm{~cm}$ de profundidade a estrutura que ocorreu foi $F(\mu)$, com presença de fissuras, agregados pequenos e médios, arredondados, externamente subangulares e internamente granulares, com macroporosidade visível importante de empilhamento de agregados, grande número de bioporos e de raízes. A 


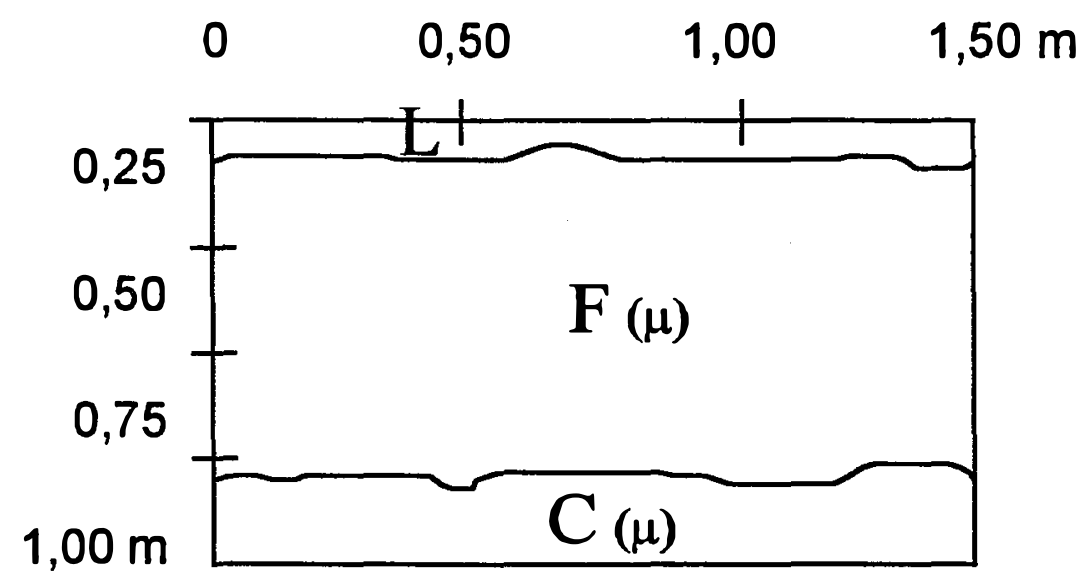

Figura 10. Perfil cultural do solo sob mata nativa.

profundidades maiores que $70-80 \mathrm{~cm}$ a estrutura foi do tipo $\mathrm{C}(\mu)$, onde se observou um volume contínuo, com agregados pequenos e granulares, típicos de latossolo roxo, com estrutura "pó de café" (Pedro et al., 1976) e menor ocorrência de raízes. A densidade do solo por profundidade, determinada em amostras retiradas com anel (Tabela 17) apresentou valores de 0,85; 0,95 e $1,0 \mathrm{~kg} \mathrm{dm}^{-3}$ e porosidade de 0,$693 ; 0,667$ e $0,650 \mathrm{dm}^{3}$ $\mathrm{dm}^{-3}$, para as profundidades de $0-10,10-20$ e $20-40 \mathrm{~cm}$, respectivamente. Quando avaliada por estruturas (Tabela 18 e Figura 16), as densidades obtidas foram de 1,29; 1,39 e $1,32 \mathrm{~kg} \mathrm{dm}^{-3}$ e as porosidades foram de 0,$568 ; 0,513$ e $0,541 \mathrm{dm}^{3} \mathrm{dm}^{-3}$, para as estruturas $\mathrm{L}, \mathrm{F}(\mu)$ e $\mathrm{C}(\mu)$, respectivamente.

Quanto à distribuição por tamanho de poros do solo da mata (Tabela $18 \mathrm{e}$ Figura 16) nota-se que a porosidade total foi semelhante nas estrutura $L, F(\mu)$ e $\mu$, o que mostra um solo fisicamente não modificado. A porosidade $>50 \mu \mathrm{m}$ é importante para as três estruturas, variando de $0,2159 \mathrm{dm}^{3} \mathrm{dm}^{-3}$, na estrutura $\mathrm{L}$ até $0,1048 \mathrm{dm}^{3} \mathrm{dm}^{-3}$, na estrutura $\mu$, evidenciando as boas condições fisicas do solo virgem.

Para os perfis culturais observados no pomar, observou-se que, para todos os sistemas de manejo de solo (Figuras 11 a 15), o volume de solo NAM (aparentemente não alterado pelo manejo) iniciou-se à profundidade de $30-40 \mathrm{~cm}$, com as alterações bem 
Tabela 18. Porosidade de acordo com a distribuição do tamanho de poros, volume total de poros $\left(\mathrm{em} \mathrm{dm}^{3} \mathrm{dm}^{-3}\right)$ e densidade do solo e de partículas $\left(\mathrm{em} \mathrm{kg} \mathrm{dm}^{-3}\right)$ das estruturas observadas nos perfis culturais.

\begin{tabular}{|c|c|c|c|c|c|c|c|c|}
\hline \multirow[b]{2}{*}{ Situação } & \multirow{2}{*}{$\begin{array}{r}\text { tipo } \\
\text { agreg. }\end{array}$} & \multicolumn{6}{|c|}{ Porosidade } & \multirow{3}{*}{$\begin{array}{l}\text { Densid } \\
\text { solo } \\
\mathrm{kg} \mathrm{dm}^{-3}\end{array}$} \\
\hline & & $<0,2 \mu \mathrm{m}$ & $2-6 \mu \mathrm{m}$ & $6-50 \mu \mathrm{m}$ & $>50 \mu \mathrm{m}$ & $<50 \mu \mathrm{m}$ & VTP & \\
\hline & & \multicolumn{6}{|c|}{$\mathrm{dm}^{3} \mathrm{dm}^{-3}$} & \\
\hline rachis & $\mu$ & 0,2962 & 0,0477 & 0,1243 & 0,0623 & 0,468 & 0,531 & 1,34 \\
\hline Arachis & $\Delta \mu / \Delta$ & 0,2574 & 0,0489 & 0,1191 & 0,0611 & 0,425 & 0,487 & 1,46 \\
\hline achis & $\Delta \Delta \mu$ & 2522 & 0,0572 & 4 & 58 & 0,407 & 0,473 & 1,50 \\
\hline Roçad/gr. & $\Delta \Delta \mu$ & 0,2749 & 0,0504 & 0,0867 & 0,0465 & 0,412 & 0,459 & 1,51 \\
\hline r. & $\Delta$ & 65 & 0,055 & 3 & 0,0186 & 0,391 & 0,409 & 1,68 \\
\hline Capina & $\Delta \Delta \mu$ & 0,2259 & 0,0644 & 0,221 & 0,0486 & 0,511 & 0,560 & 1,38 \\
\hline Cult. anual & $\mu$ & 0,2709 & 0,0521 & 0,1363 & 0,1017 & 0,459 & 0,561 & 1,25 \\
\hline Cult. anual & $\Delta \mu$ & 0,2663 & 0,0568 & 0,1646 & 0,0637 & 0,488 & 0,551 & 1,28 \\
\hline Cult. anual & L & 0,2509 & 0,0494 & 0,1755 & 0,0335 & 0,476 & 0,509 & 1,41 . \\
\hline Cult. anual & $\Delta \Delta \mu$ & 0,276 & 0,0614 & 0,1116 & 0,0209 & 0,450 & 0,471 & 1,52 \\
\hline Cult. anual & $\Delta$ & 0,2957 & 0,0541 & 0,058 & 0,0155 & 0,408 & 0,423 & 1,62 \\
\hline Mata & L & 0,2417 & 0,0295 & 0,0807 & 0,2159 & 0,352 & 0,568 & 1,29 \\
\hline Mata & $F(\mu)$ & 0,2902 & 0,0250 & 0,0727 & 0,1250 & 0,388 & 0,513 & 1,39 \\
\hline Mata & $\mu$ & 0,2913 & 0,0340 & 0,1107 & 0,1048 & 0,436 & 0,541 & 1,32 \\
\hline
\end{tabular}

VTP: volume total de poros determinado por porosimetria a mercúrio

nítidas ocorrendo acima desta profundidade. A estrutura NAM apresentou semelhança com a estrutura observada em profundidade na área de mata nativa, com estrutura $\mu$, porosidade visível muito forte, agregados arredondados, típicos deste tipo de solo, e fraca coesão quando seco. A densidade obtida a $20-40 \mathrm{~cm}$ de profundidade foi de 1,04 a $1,10 \mathrm{~kg} \mathrm{dm}^{-3}$ e a porosidade, realizada com anel volumétrico, foi de 0,60 a $0,64 \mathrm{dm}^{3} \mathrm{dm}^{-3}$ (Tabela 16). Quando avaliada por estrutura, a porosidade total foi de $0,531 \mathrm{dm}^{3} \mathrm{dm}^{-3}$ na estrutura $\mu$ do tratamento $A$. prostrata e a densidades desta estrutura foi de $1,34 \mathrm{~kg} \mathrm{dm}^{-3}$ 
(Tabela 18). A distribuição do tamanho de poros para esta estrutura (Tabela 18 e Figura 18) foi de 0,0623 para poros maiores que $50 \mu \mathrm{m}$ e de 0,468 para poros menores que 50 $\mu \mathrm{m}$.

Para os tratamentos com cobertura de leguminosas (A. prostrata, I. campestris e mucuna cinza) apresentados nas Figuras 11 a 13, acima da estrutura NAM ocorreu uma camada mais adensada do que a anterior, com predomínio de estruturas dos torrões tipo $\Delta \mu$ e $\Delta \mu / \Delta$, que se estende de $5-10 \mathrm{~cm}$ até $30-40 \mathrm{~cm}$ de profundidade. Estas estruturas se caracterizaram por uma maior compacidade em relação ao perfil de referência, mas ainda com boas condições estruturais. A densidade do solo obtida para a estruturas $\Delta \mu / \Delta$ no tratamento $A$. prostrata (Tabela 18) foi de $1,46 \mathrm{~kg} \mathrm{dm}^{-3}$ e a porosidade foi de $0,487 \mathrm{dm}^{3}$ $\mathrm{dm}^{-3}$. Os agregados apresentaram estrutura arredondada, com porosidade visível de empilhamento e fissural. As faces de ruptura mostraram-se lisas - rugosas a rugosas, com coesão a seco média a elevada. Nos $10 \mathrm{~cm}$ iniciais ocorreu predomínio do estado $\mathrm{L}$ (livre), constituído por terra fina, e agregados de tamanhos pequenos, sem coesão alguma, com raízes em grandes quantidades, bem ramificadas e orientadas em todas as direções. Os perfis apresentaram grande número de zonas de alta atividade biológica, caracterizados pela ocorrência de terra fina, pequenos agregados e bioporos. A distribuição do tamanho de poros (Tabela 18 e Figura 18) do tratamento $A$. prostrata indicou um decréscimo na porosidade total, quando a estrutura passou de $\mu$ para $\Delta \mu / \Delta \mathrm{e}$ $\Delta \Delta \mu$, porém a porosidade $>50 \mu \mathrm{m}$ manteve-se praticamente constante, indicando que este sistema de manejo manteve a estrutura do solo. Este desempenho de cobertura vegetal de leguminosa em relação à estrutura do solo foi observado também por Greacen \& Perkman (1953), que encontraram diferenças significativas na densidade e porosidade do solo na profundidade de $0-10 \mathrm{~cm}$ em um pomar cítrico australiano.

Para o sistema de manejo Roçadeira/Grade (Figura 14) a presença de zonas de atividade biológica foi pequena. Constatou-se a ocorrência de uma camada de maior densidade, contínua na profundidade de $5-15 \mathrm{~cm}$, com estrutura $\Delta / \Delta \mu$ em toda a extensão havendo estrutura $\Delta$ em alguns locais. A densidade dos torrões foi de 1,51 e $1,68 \mathrm{~kg} \mathrm{dm}^{-3}$ e a porosidade foi de 0,459 e $0,409 \mathrm{dm}^{3} \mathrm{dm}^{-3}$, respectivamente para as duas estruturas. 
Refletindo a densidade elevada dessas estruturas, os agregados apresentaram estrutura angulosa (poliédrica), típica de solos compactados e uma porosidade visível pouco desenvolvida, com predominância de poros tubulares e fissuras. As faces de ruptura foram principalmente lisas-rugosas com elevada coesão a seco. A presença dessa camada mais compacta no tratamento Roçadeira/Grade mostra efeito da mecanização na estrutura do solo, reduzindo a porosidade e aumentando a densidade (Pagliai, 1987; Manichon, 1987), ocasionando o chamado "pé-de-grade". A parcela da porosidade mais atingida pelo manejo é a de poros maiores, ou macroporosidade, que resulta dos espaços entre os agregados. $\mathrm{O}$ adensamento do solo provocado pelo manejo aproximou os agregados entre si, reduzindo a macroporosidade, como pode ser visto na Tabela 18 e Figura 19 , onde se comparam as estruturas $\Delta$ e $\Delta / \Delta \mu$. Ao passar para o estado mais compactado $(\Delta)$ a porosidade total do solo não foi sensivelmente afetada, ao contrário da porosidade $>50 \mu \mathrm{m}$, que passou de 0,0465 para $0,0186 \mathrm{dm}^{3} \mathrm{md}^{-3}$. Cintra et al. (1983) observaram na Bahia, em latossolo amarelo distrófico, em pomar cítrico, que a densidade do solo e a resistência à penetração foram menores para os tratamentos gradagem /ceifa $\mathrm{e}$ para ceifa permanente, que tiveram maior incremento no teor de matéria orgânica. A gradagem permanente promoveu redução no tamanho dos agregados e na porcentagem de agregação, além de formar uma camada compactada de 10-15 cm. Greacen \& Perkman (1953) observaram densidade do solo significativamente mais elevada com vegetação natural ceifada e herbicida do que com cultivo no verão mais adubo verde no inverno e cultivo no verão mais adubo verde no inverno mais esterco. No presente trabalho, entretanto, estas diferenças de densidade e porosidade observadas nas estruturas levantadas no perfil cultural não foram detectadas na amostragem por profundidade, onde os tratamentos $A$. prostrata, Roçadeira/grade e Capina não diferiram entre si (Tabela 16). Desta forma, o método do perfil cultural, através da abertura de trincheiras e da observação da forma de organização e da morfologia das estruturas do solo nos diferentes volumes do perfil, permitiu uma avaliação mais abrangente do estado fisico do solo e dos fatores envolvidos. 
Nas trincheiras abertas no tratamento Capina não se observou a presença de zonas de atividade biológica, provavelmente em função das condições propiciadas pelo solo desnudo, com grande variação de temperatura e umidade e ausência de material vegetal para servir de abrigo e alimento à fauna do solo. Nesse sistema de manejo o padrão do perfil cultural foi o de ocorrência da estrutura $\mathrm{L}$ somente próximo ao tronco da árvore, até a projeção da copa. A partir daí, e em direção ao centro da rua, foi observada uma camada compactada iniciando-se na superficie até a profundidade de 30$40 \mathrm{~cm}$, com estruturas $\Delta \mathrm{e} \Delta \Delta \mu$. Esta particularidade está associada ao fato de que nesse tipo de manejo o solo das ruas do pomar permanece descoberto permanentemente. Desta forma, fica desprotegido dos efeitos da chuva, que através do impacto das gotas, causa a desestruturação dos agregados, liberando as partículas. Como a textura do solo estudado é argilosa, estas partículas se rearranjam, preenchendo os espaços vazios e formam crostas superficiais (Zachar, 1982; Fies \& Castelao-Gergunde, 1996). Como na ocasião da amostragem os tratamentos encontravam-se a campo por 10 anos, este tempo foi suficiente para que este efeito se manifestasse. A formação de crostas superficiais, aumentando a densidade do solo e reduzindo a velocidade de infiltração de água foi também observada em pomar de citros no qual o solo foi deixado descoberto pelo uso de herbicida por Cintra et al. (1983).

Quando os resultados da distribuição da quantidade de raízes são analisados em conjunto com os do perfil cultural (Figuras 20 a 24), nota-se, visualmente, que não há uma relação forte entre estes dois parâmetros, isto é, não existe um tipo de estrutura preferencial para a concentração de raízes, como também não existe um tipo de estrutura em que as raízes não ocorram. Isto deve-se provavelmente ao fato de que todas as estruturas detectadas estão dentro dos limites considerados satisfatórios para 0 desenvolvimento das raízes. De acordo com Gregory (1988), a densidade limite, que permite o crescimento radicular para as culturas em geral, para solos argilo siltosos é de $1,55 \mathrm{~kg} \mathrm{dm}^{-3}$. Os resultados aqui apresentados, mesmo para a estrutura $\Delta$, mais compactada, situaram-se abaixo deste valor, com exceção da estrutura $\Delta$ do tratamento Roçadeira/Grade, que atingiu $1,68 \mathrm{~kg} \mathrm{dm}^{-3}$, mas mesmo assim apresentou grande 
quantidade de raízes (Figura 23). Tardieu \& Manichon (1987), porém, demonstraram que o sistema radicular do milho foi sensível a variações de densidade, apresentando desenvolvimento bem menor quando a densidade foi de $1,55-1,69 \mathrm{~kg} \mathrm{dm}^{-3}$, intermediário com densidade de $1,43 \mathrm{~kg} \mathrm{dm}^{-3}$, e maior com densidade $1,30-1,45 \mathrm{~kg} \mathrm{dm}^{-3}$, num solo siltoso. Os autores relataram; no entanto, que em outro trabalho em desenvolvimento, outras espécies, como a fava, apresentaram comportamento diferente do observado no sistema radicular do milho. Para a macieira (Malus domestica L.), Webster (1978) concluiu que a porosidade total abaixo da qual as raízes são muito esparsas ou inexistentes foi de $0,30-0,35 \mathrm{dm}^{3} \mathrm{dm}^{-3}$ para solos de textura média e de $0,33-0,39 \mathrm{dm}^{3}$ $\mathrm{dm}^{-3}$ para solos arenosos. Tomando estas referências como base, as porosidades observadas no presente trabalho, que se situaram entre 0,40 e $0,56 \mathrm{dm}^{3} \mathrm{dm}^{-3}$, não agiram, portanto, como obstáculo para o desenvolvimento das raízes.

Para as plantas cítricas, Mazza et al. (1994) constataram que as raízes tinham menor desenvolvimento em solos compactados, que apresentavam $0,10 \mathrm{dm}^{3} \mathrm{dm}^{-3} \mathrm{de}$ macroporosidade e densidade $1,80 \mathrm{~kg} \mathrm{dm}^{-3}$, enquanto solos com macroporosidade de $0,32 \mathrm{dm}^{3} \mathrm{dm}^{-3}$ e densidade $1,39 \mathrm{~kg} \mathrm{dm}^{-3}$, apresentavam um enraizamento abundante. Da mesma forma, Avilan et al. (1986) em solos da Venezuela, constataram que o crescimento radicular de diversas combinações de copa/porta-enxerto nos citros foi restringido com macroporosidade abaixo de $0,05 \mathrm{dm}^{3} \mathrm{dm}^{-3}$. Pace \& Araujo (1986) estudaram a distribuição das raízes (com diâmetro menor ou igual a $1,5 \mathrm{~mm}$ ) de três porta-enxertos sob laranja 'Natal', em solo podzólico. Houve uma redução abrupta do percentual de radicelas a profundidades maiores que $20 \mathrm{~cm}$, local da mudança textural entre os horizontes A e B, com a quantidade de argila aumentando de $15-20 \%$ para $48 \%$, e a densidade do solo passando de 1,29-1,35 para 1,44 $\mathrm{kg} \mathrm{dm}^{-3}$. Essa redução de raízes em função de horizontes argilosos de subsuperficie foi também constatada por Avilan et al.(1986).

Solos muito argilosos têm sido considerados pouco apropriados para os citros (Jones \& Embleton, 1973; Platt, 1973), pois geralmente dificultam a drenagem, que é um dos principais fatores limitantes para o desenvolvimento de suas raízes. Além disso, de 
acordo com Greenland (1979), o desenvolvimento das raízes, de maneira geral, é restrito a fissuras neste tipo de solo em relação a solos de textura mais grossa, em função do tamanho dos poros predominantes. Sánchez et al. (1988), em um levantamento das condições de pomares cítricos venezuelanos situados em solos rasos ou com horizonte B textural, encontraram alta correlação entre o desenvolvimento da copa e a quantidade de raízes a $60-90 \mathrm{~cm}$ de profundidade e destas com os atributos do solo relacionados com o fluxo de água e ar: porosidade, densidade do solo, difusão de oxigênio, presença de fendas e teor de argila. Nos resultados aqui apresentados, o elevado teor de argila do solo estudado (latossolo roxo, com cerca de $700 \mathrm{~g} \mathrm{~kg}^{-1}$ de argila), parece não ter causado impedimento ao desenvolvimento radicular. Segundo Sanchez (1981) apesar do elevado teor de argila, este tipo de solo apresenta boa infiltração de água pois suas partículas cimentadas por óxidos de ferro e alumínio apresentam alta estabilidade, formando microagregados que fisicamente se comportam de maneira semelhante à areia em relação ao fluxo de água. Os resultados aqui apresentados confirmam estas últimas observações, pois não se constataram restrições ao desenvolvimento das raízes, mesmo nas regiões dos perfis de maior densidade, como pode ser visto nas Figuras 20 a 24 . 

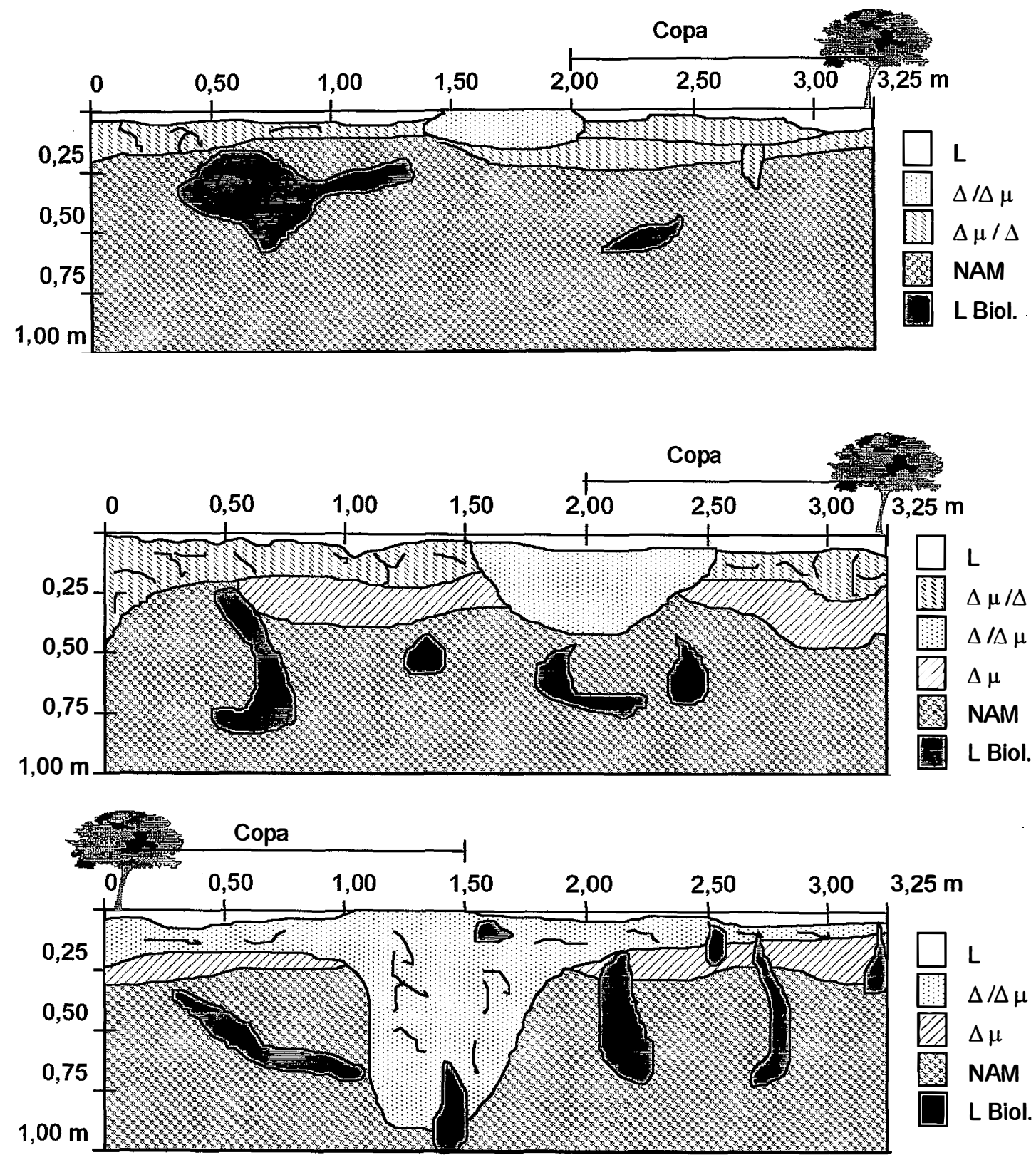

Figura 11. Perfil cultural observado em trincheiras do pomar com manejo de solo de cobertura permanente de Indigofera campestris nas entrelinhas. 

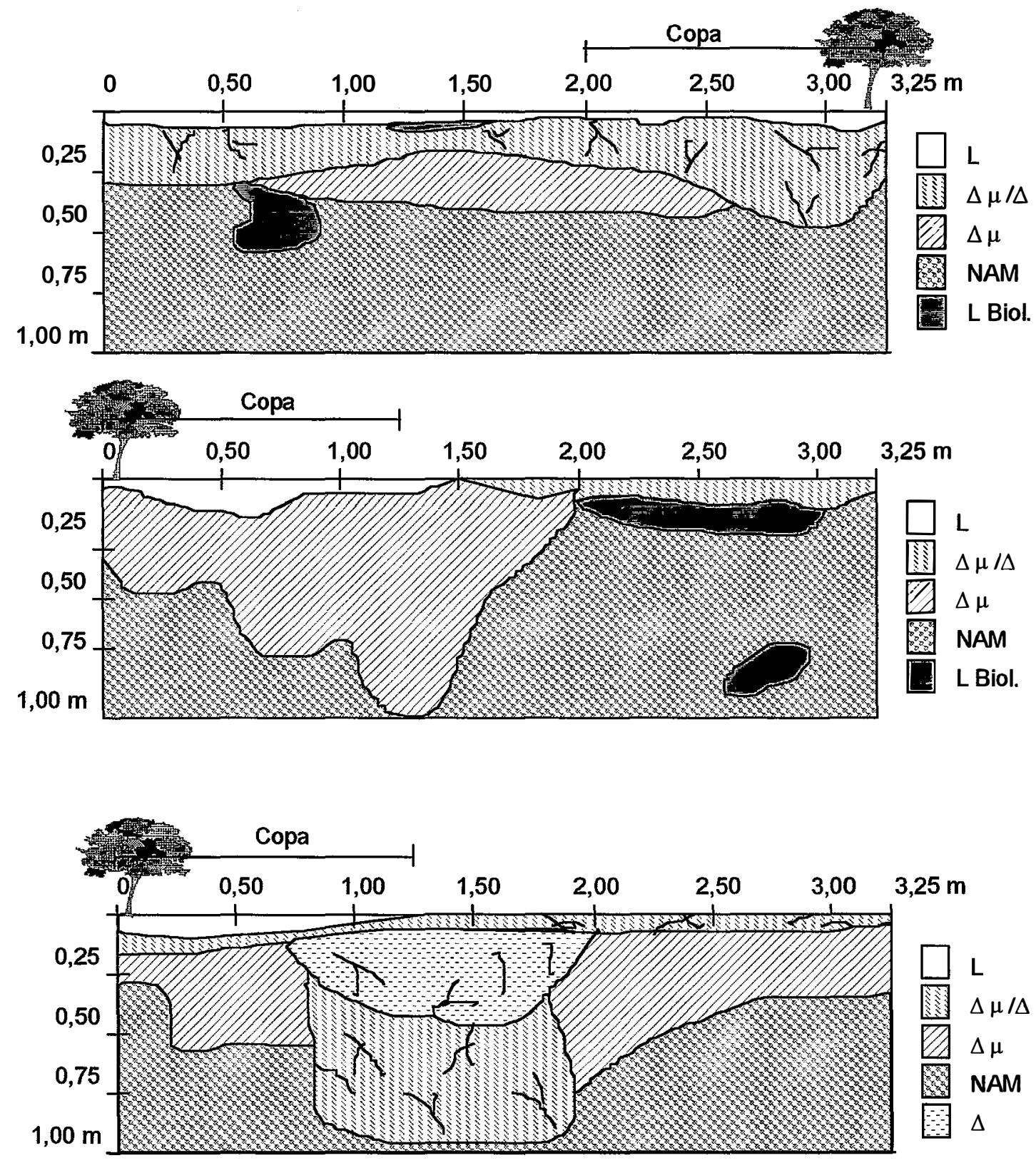

Figura 12. Perfil cultural observado em trincheiras do pomar com manejo de solo de cobertura permanente de Arachis prostrata nas entrelinhas. 

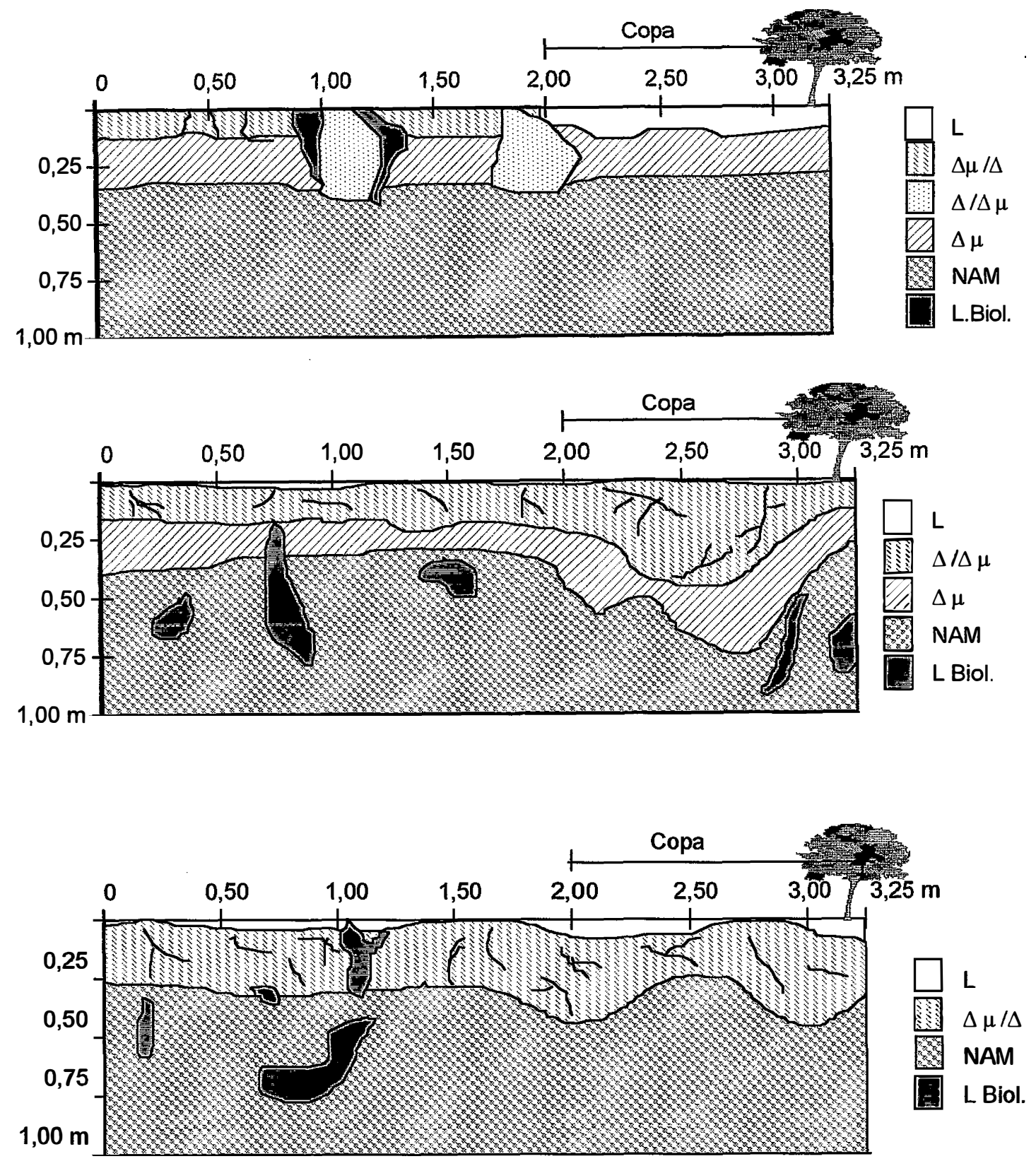

Figura 13. Perfil cultural observado em trincheiras do pomar com manejo de solo de Mucuna cinza nas entrelinhas. 

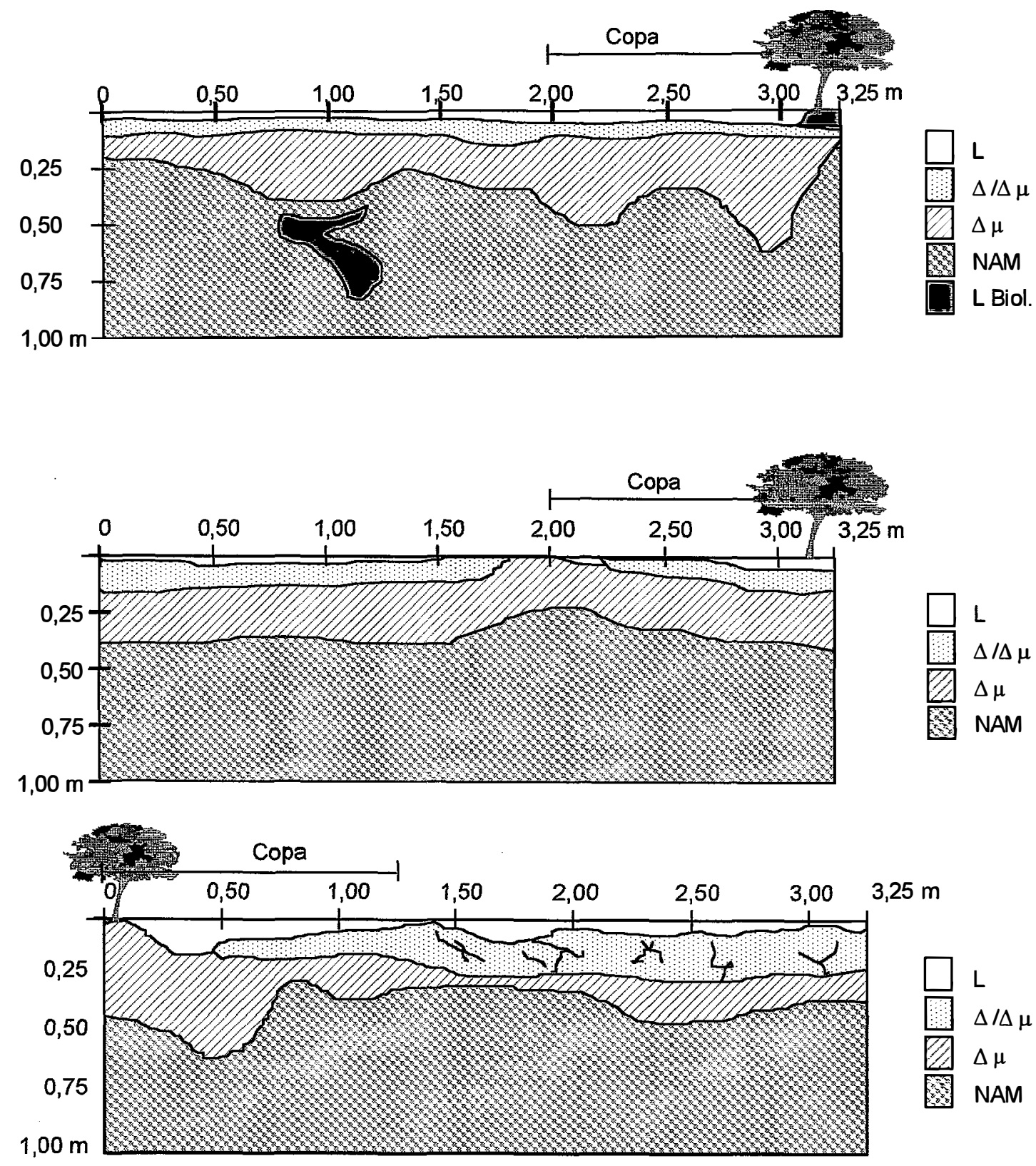

Figura 14. Perfil cultural observado em trincheiras do pomar com manejo de solo de Roçadeira/ Grade nas entrelinhas. 

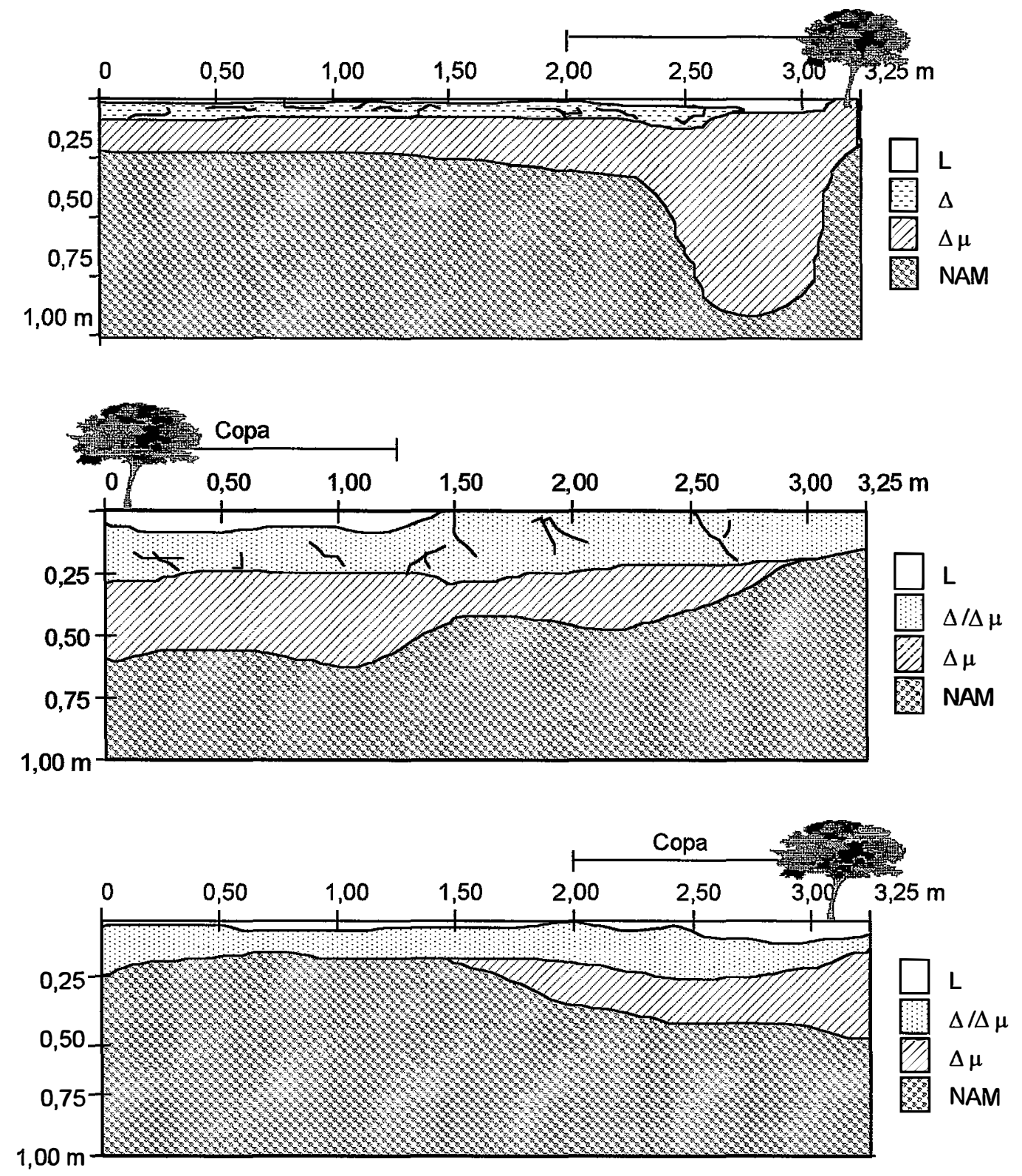

Figura 15. Perfil cultural observado em trincheiras do pomar com manejo de solo de capina. 


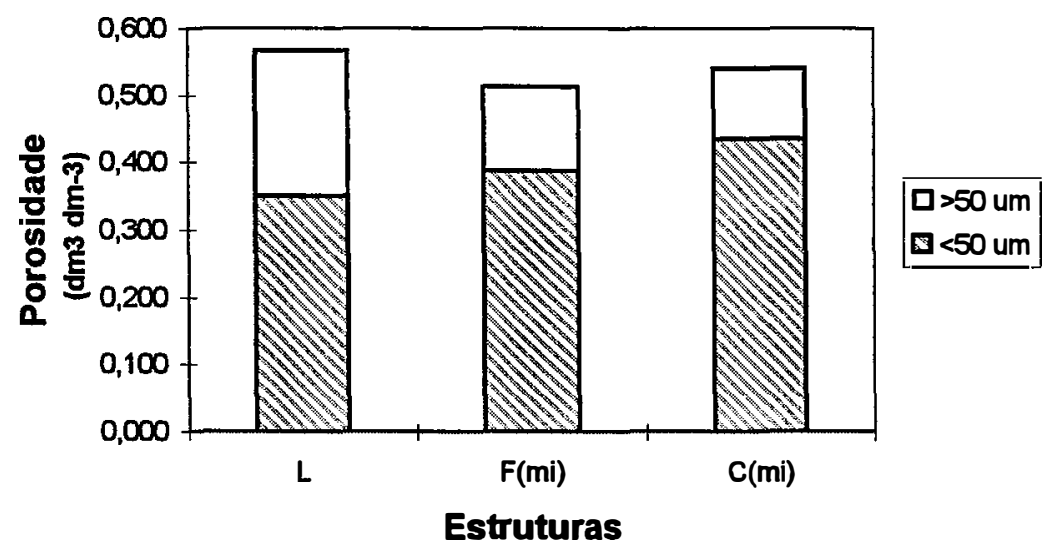

Figura 16. Porosidade $>50 \mu \mathrm{m} \mathrm{e}<50 \mu \mathrm{m}$ de estruturas observadas no perfil cultural de das estruturas de solo sob mata nativa. $L=$ livre; delmi $=\Delta \mu ; \mathrm{Mi}=\mu$.

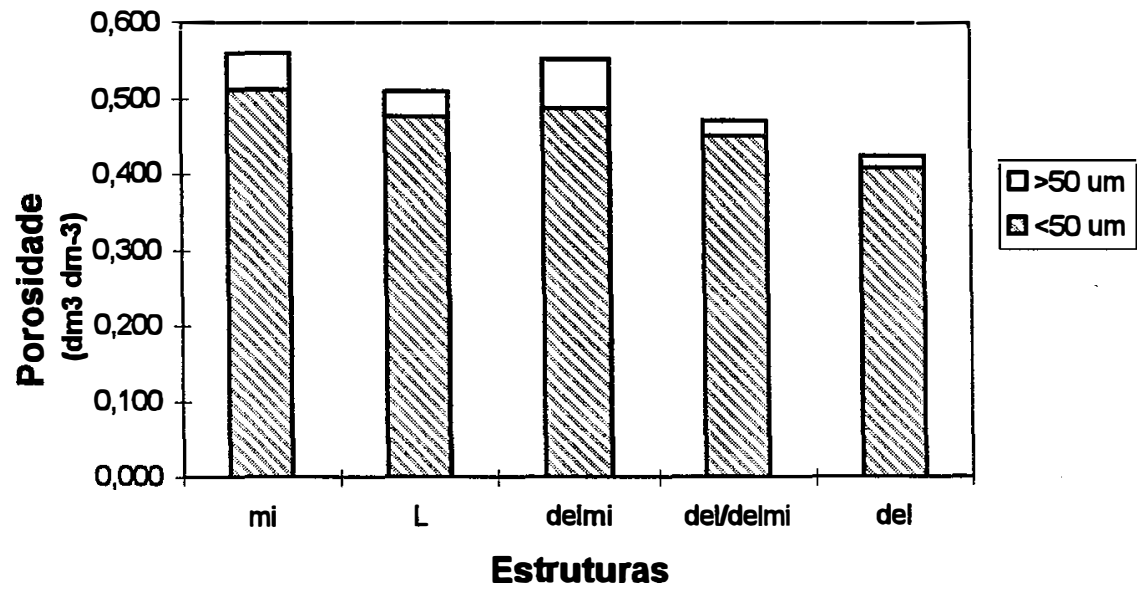

Figura 17. Porosidade $>50 \mu \mathrm{m} \mathrm{e}<50 \mu \mathrm{m}$ de estruturas observadas no perfil cultural de cultura anual. $\mathrm{Mi}=\mu ; \mathrm{L}=$ livre; delmi $=\Delta \mu ;$ del $/$ delmi $=\Delta / \Delta \mu ;$ del $=\Delta$ 


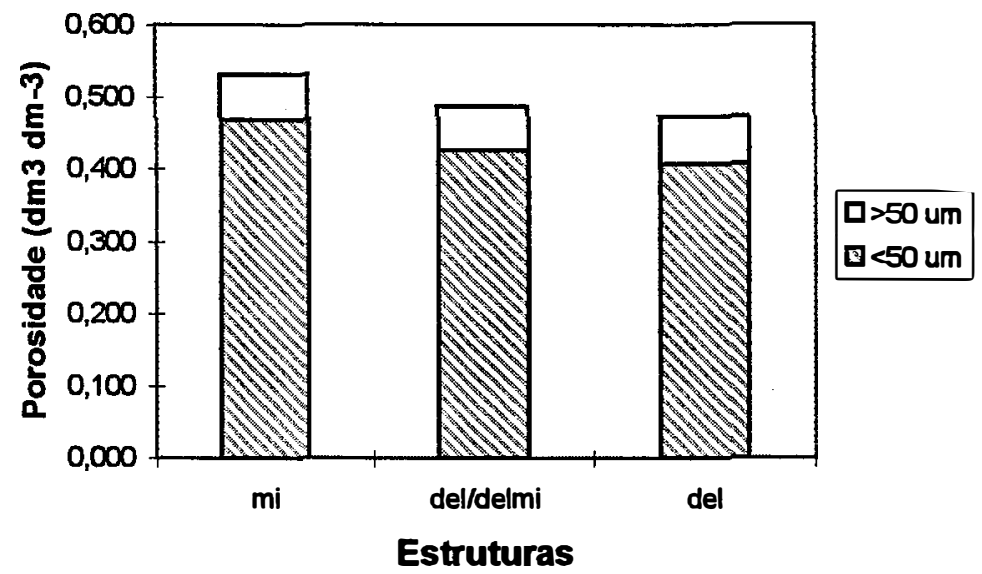

Figura 18. Porosidade $>50 \mu \mathrm{m} \mathrm{e}<50 \mu \mathrm{m}$ de estruturas observadas no perfil cultural do manejo de solo Arachis prostrata. $\mathrm{Mi}=\mu ; \mathrm{del} / \mathrm{delmi}=\Delta / \Delta \mu ;$ del $=\Delta$

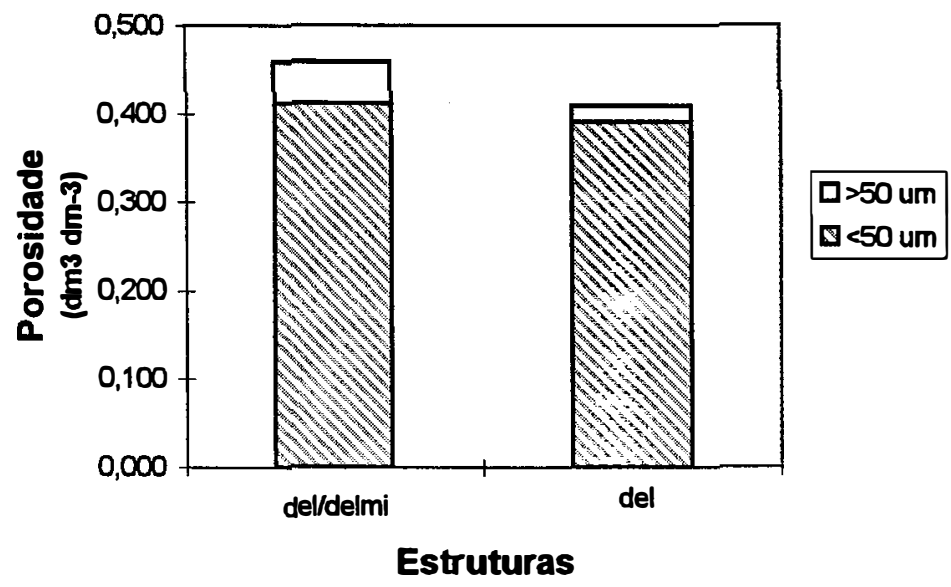

Figura 19. Porosidade $>50 \mu \mathrm{m} \mathrm{e}<50 \mu \mathrm{m}$ de estruturas observadas no perfil cultural do manejo de solo Roçadeira/Grade. Del/delmi $=\Delta / \Delta \mu ;$ del $=\Delta$ 

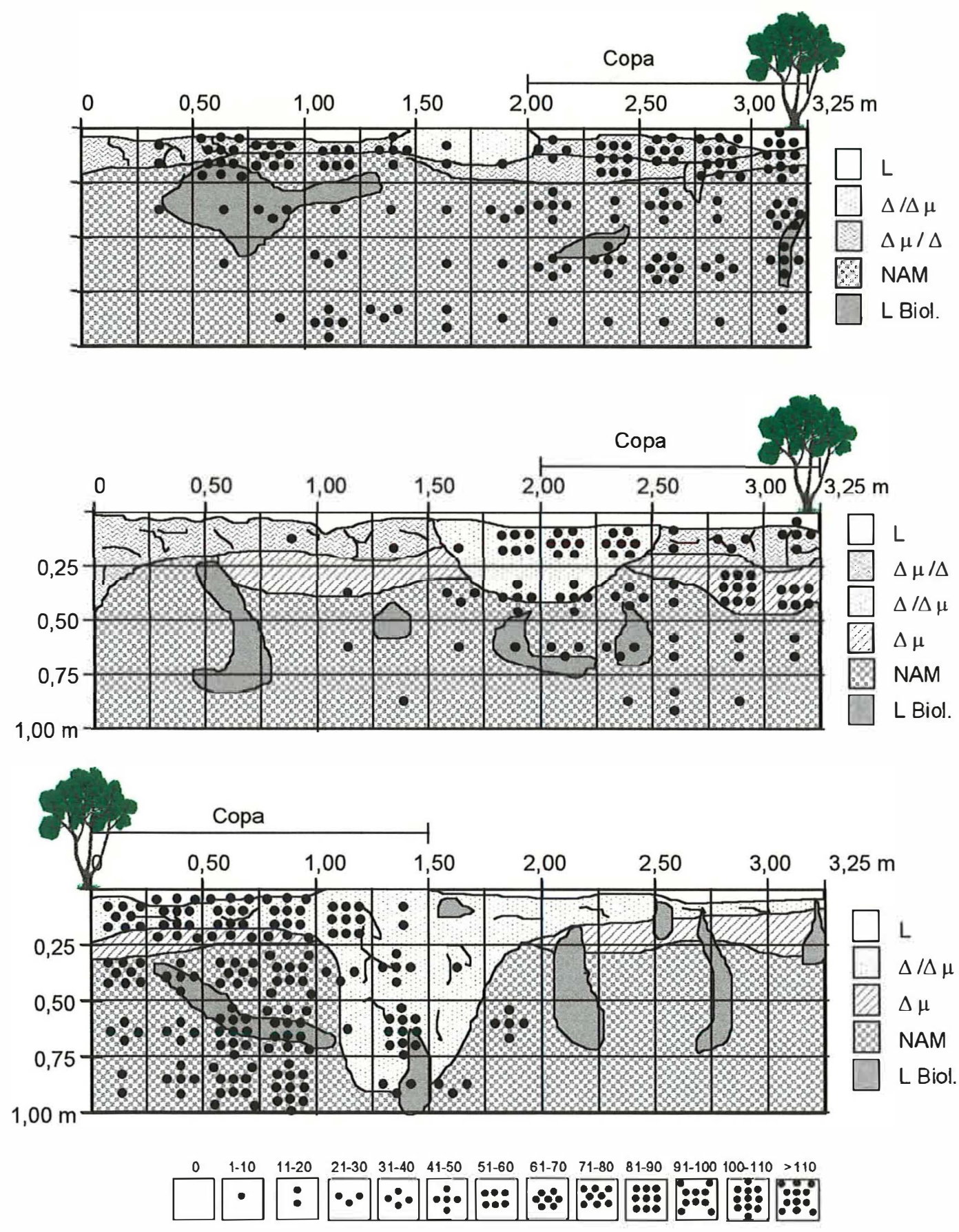

Comprimento de raízes $(\mathrm{cm})$

Figura 20. Perfil cultural e distribuição de raízes de tangerina 'Poncã' enxertada sobre limão 'Cravo' com o manejo de solo de cobertura permanente de Indigofera campestris. 

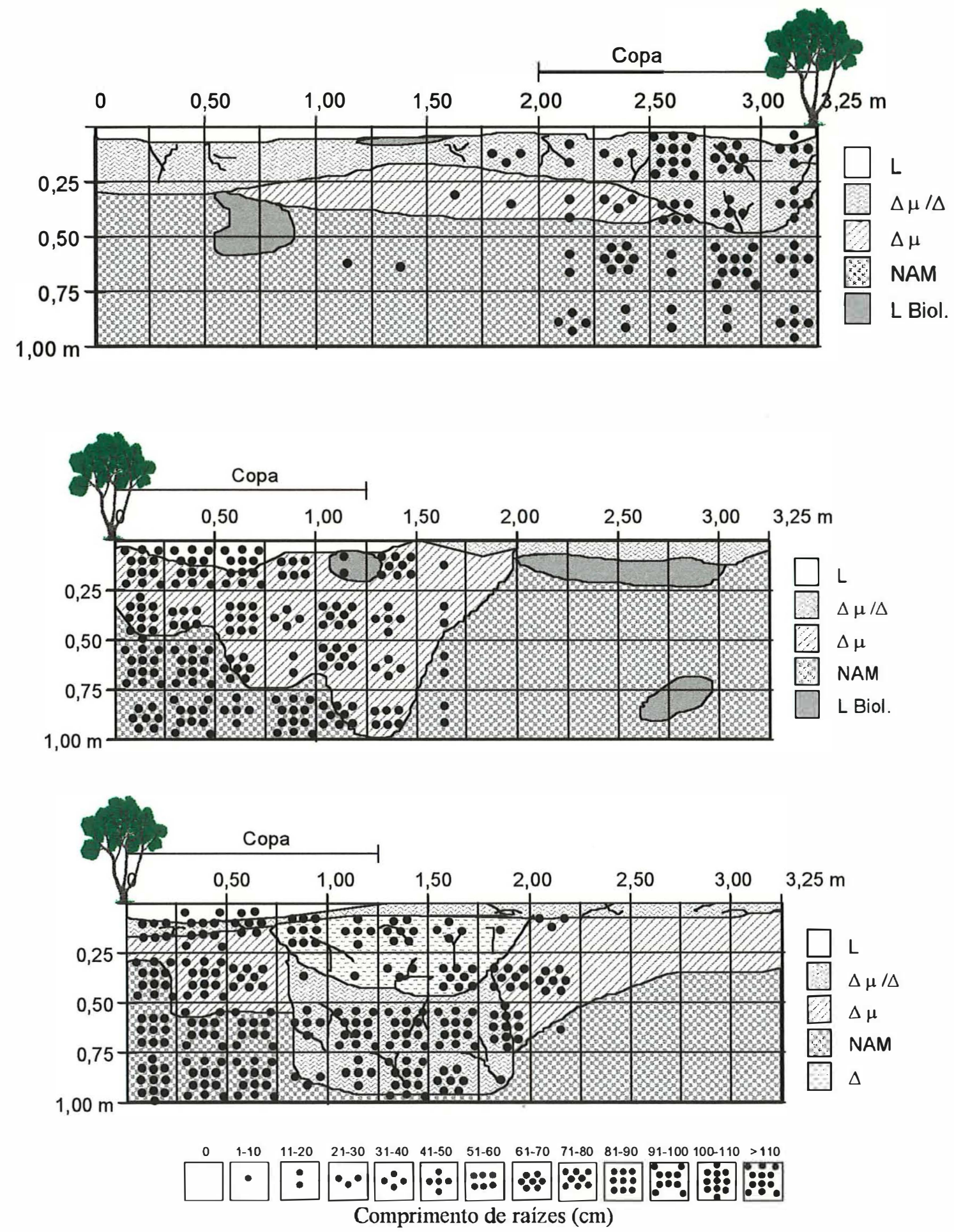

Figura 21. Perfil cultural e distribuição de raízes de tangerina 'Poncã' enxertada sobre limão 'Cravo' com o manejo de solo com cobertura permanente de Arachis prostrata. 

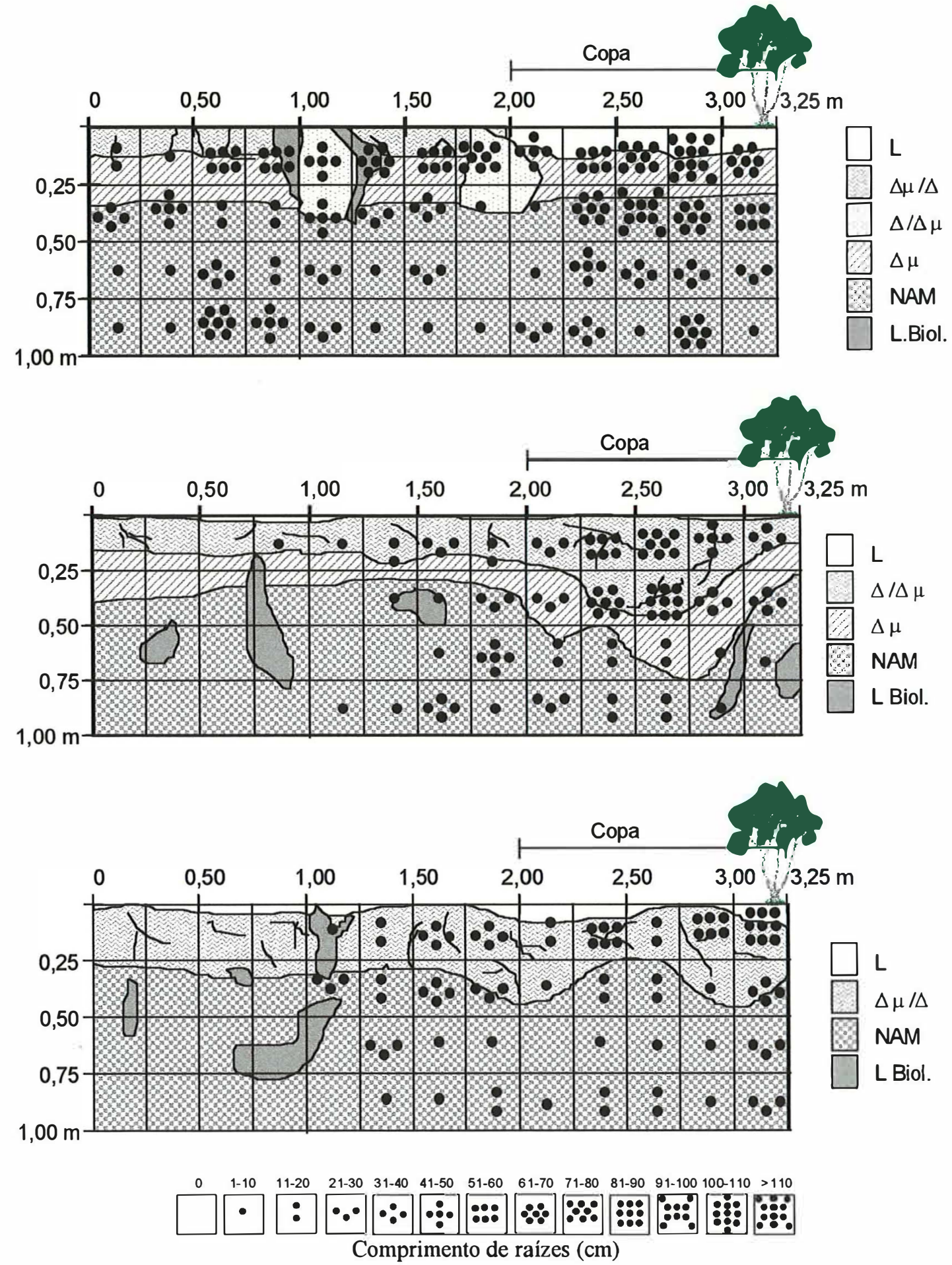

Figura 22. Perfil cultural e distribuição de raízes de tangerina 'Poncã' enxertada sobre limão 'Cravo' com manejo de solo de Mucuna cinza. 

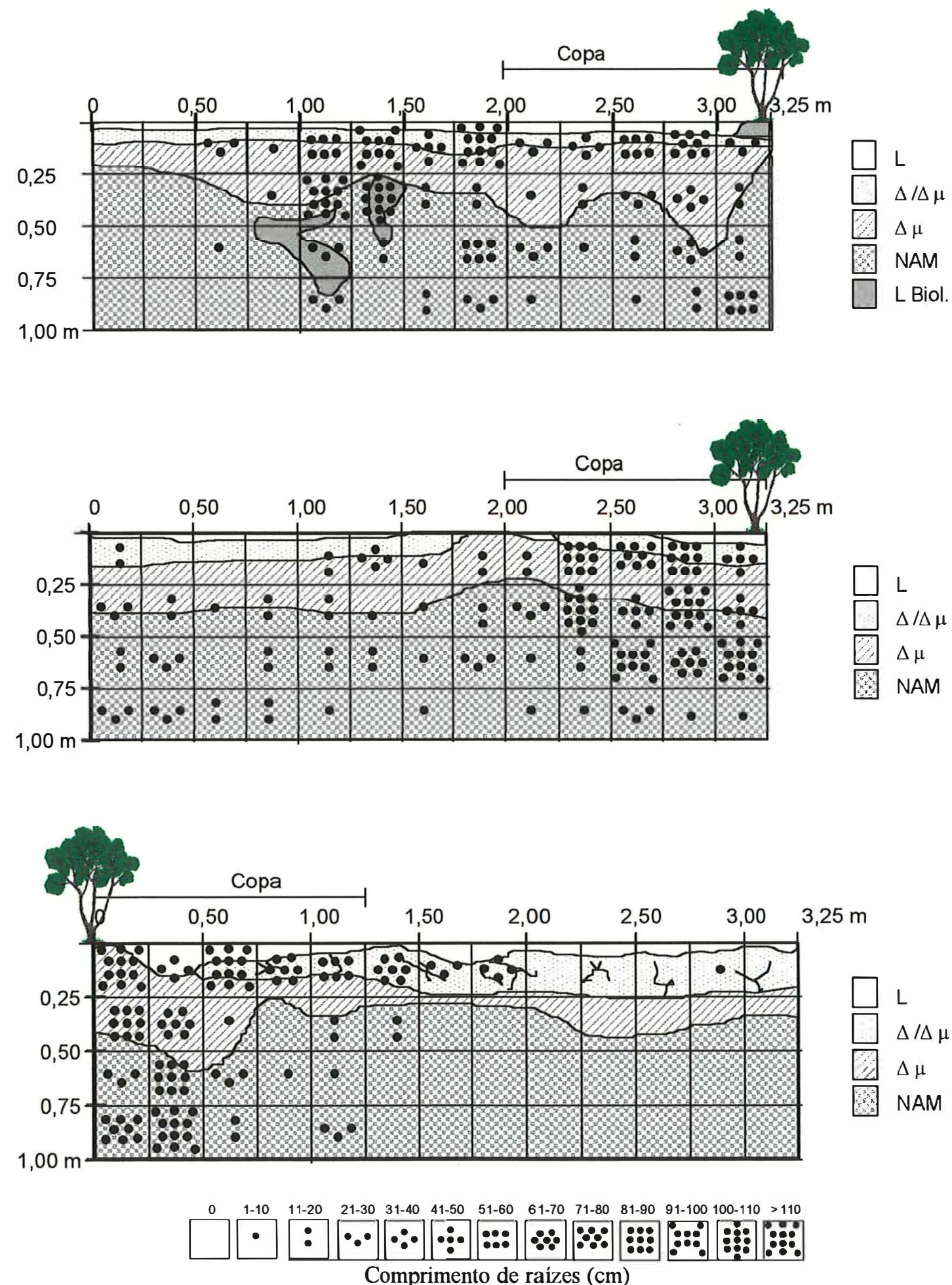

Figura 23. Perfil cultural e distribuição de raízes de tangerina 'Poncã' enxertada sobre limão 'Cravo' com o manejo de solo com Roçadeira/Grade. 

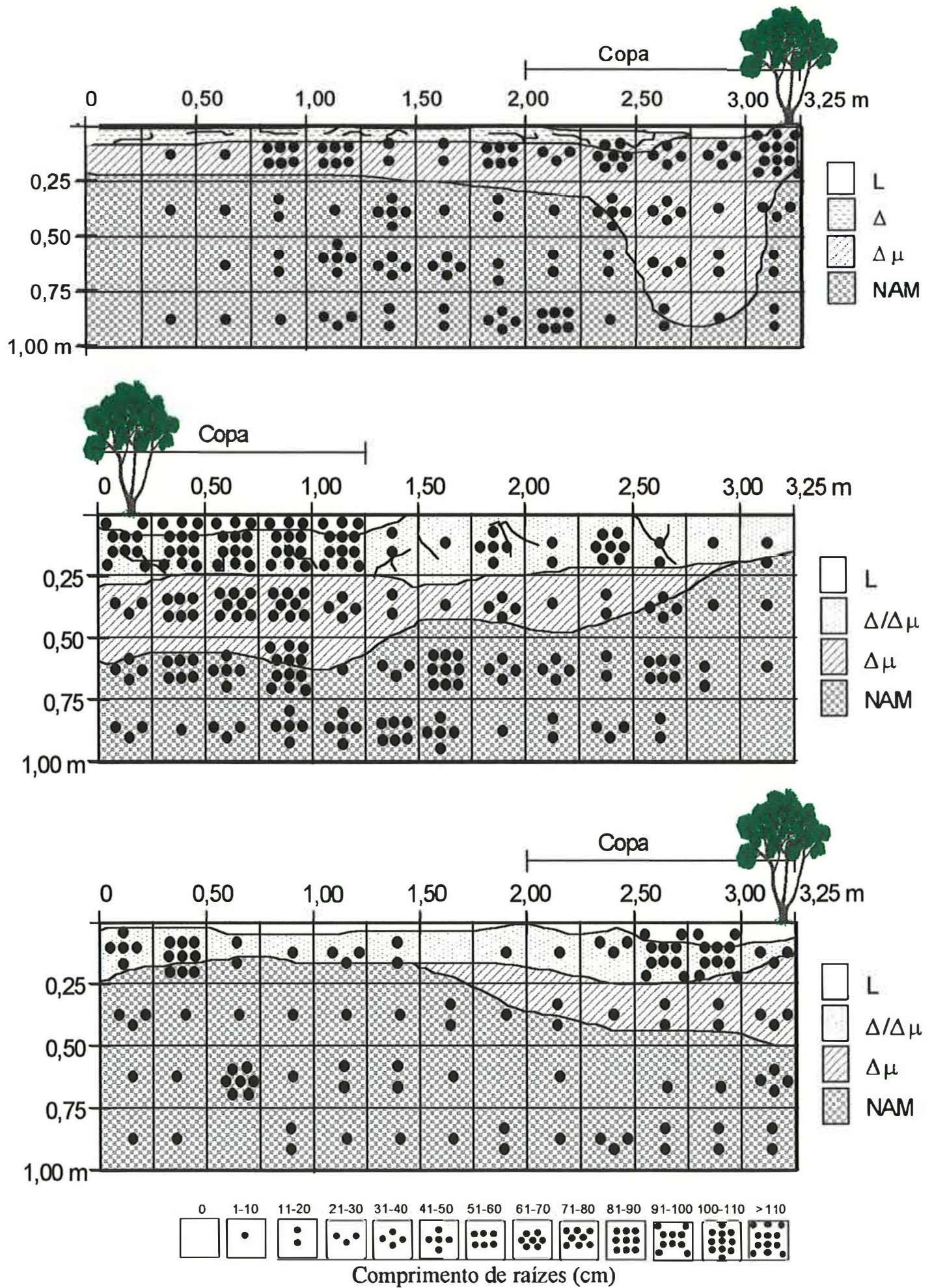

Figura 24. Perfil cultural e distribuição de raízes de tangerina 'Poncã' enxertada sobre limão 'Cravo' com manejo de solo de Capina. 


\section{6 Conclusões}

Através da análise dos resultados deste trabalho pode-se concluir que:

- A quantidade total de raízes das plantas cítricas não foi afetada pelos sistemas de manejo de solo avaliados.

- A distribuição do sistema radicular dos citros apresentou diferenças significativas entre os sistemas de manejo: a presença de vegetação nas entrelinhas limitou as raízes às regiões do perfil onde não havia raízes das plantas de cobertura.

- A cobertura de solo com Arachis prostrata induziu significativamente o aprofundamento do sistema radicular dos citros

- As coberturas de leguminosas possibilitaram a manutenção das condições fisicas do solo, avaliadas pelo perfil cultural.

- O uso de gradagem/roçadeira e o solo mantido descoberto provocaram camadas compactadas respectivamente na profundidade de $5-15 \mathrm{~cm}$ e na superficie, o que, entretanto, não impediu o crescimento radicular. 
5 EFEITO DE COBERTURA DE SOLO DE POMAR CÍTRICO COM VEGETAÇÃO ESPONTÂNEA OU LEGUMINOSA NO FRACIONAMENTO GRANULOMÉTRICO DA MATÉRIA ORGÂNICA DE UM LATOSSOLO ROXO 


\section{EFEITO DE COBERTURA DE SOLO DE POMAR CÍTRICO COM VEGETAÇÃO ESPONTÂNEA OU LEGUMINOSA NO FRACIONAMENTO GRANULOMÉTRICO DA MATÉRIA ORGÂNICA DE UM LATOSSOLO ROXO}

\subsection{Resumo}

Estudou-se o efeito de sistemas de manejo do solo, mantidos durante nove anos em um pomar cítrico, nos teores de carbono e nitrogênio, relação $\mathrm{C} / \mathrm{N}$, estoque de carbono e no fracionamento granulométrico da matéria orgânica do solo. Os testes foram realizados também em amostras do mesmo solo sob floresta nativa e sob culturas anuais durante 20 anos. 0 teor de matéria orgânica do solo foi aumentado com as coberturas de A. prostrata e gradagem/ roçadeira em relação ao teor inicial do pomar. As perdas de carbono (em mg C $\mathrm{g}^{-1}$ de solo) na camada 0-10 $\mathrm{cm}$ quando o solo passou da vegetação nativa para as culturas, foram de 12 a $45 \%$, sendo maiores com culturas anuais por 20 anos. A fração que mais perdeu matéria orgânica foi a fração 200-2.000 $\mu \mathrm{m}$. Para todas as situações estudadas, a maior proporção da matéria orgânica do solo encontrou-se na fração organo-argilosa $(0-2 \mu \mathrm{m})(34$ a $43 \%$ do total) seguida da fração organo-siltosa $(0-20 \mu \mathrm{m})(23$ a $28 \%$ do total $)$.

5.2 Summary: EFFECT OF ORCHARD SOIL MANAGEMENT ON SOIL ORGANIC MATTER PARTICLE FRACTIONATING ON AN OXISSOL 
It was studied the effect of systems of soil management, maintained for nine years in a citrus orchard, on soil carbon and nitrogen concentrations, $\mathrm{C} / \mathrm{N}$ ratio, stock of carbon and on the particle size fractions of the organic matter of the soil. The tests were also accomplished in samples of the same soil under native forest and under annual crops for 20 years. The content of organic matter of the soil was increased with the ground cover $A$. prostrata and with mowing / tillage. The losses of carbon (in $\mathrm{mg} \mathrm{C}^{-1}$ of soil) in the layer $0-10 \mathrm{~cm}$ when the soil passed from the native vegetation to the crops went from 12 to $45 \%$, being larger with annual crops for 20 years. For all situations, the largest proportion of the soil organic matter was found in the organic-clay fraction $(0-2 \mu \mathrm{m})(34$ to $43 \%$ of the total) followed by the organic-silt fraction $(0-20 \mu \mathrm{m})(23$ to $28 \%$ of the total). With the introduction of the crops, the fraction that lost most organic matter was 200-2.000 $\mu \mathrm{m}$ fraction, in the two studied depths.

\section{3 Introdução}

A qualidade do solo pode ser definida como sua habilidade de funcionar, dentro de um ecossistema natural ou manejado, de modo a sustentar a produtividade animal e vegetal, manter ou melhorar a qualidade da água e do ar, e permitir a habitação e saúde humanas. Karlen et al. (1997) apontaram diversos atributos como indicadores desta qualidade, dentre eles a matéria orgânica do solo, que é citada também por Feller (1995a) como um dos indicadores potenciais da durabilidade dos sistemas agrícolas, podendo ser usada isoladamente ou como componente de um modelo mais complexo.

A matéria orgânica do solo desempenha papéis importantes na manutenção da fertilidade do solo, pois age como agente cimentante na formação dos agregados, aumenta a capacidade de troca de cátions do solo e é fonte de nutrientes para as plantas. $\mathrm{O}$ teor de matéria orgânica do solo em ecossistemas naturais mantém-se relativamente estável pois há um equilíbrio entre as adições e as perdas. Com a introdução de práticas agrícolas a quantidade de matéria orgânica do solo tende a diminuir, pois a adição 
geralmente é redurida e as perdas se intensificam com o maior revolvimento e aeração do solo. Com o tempo, estabelece-se um novo equilíbrio, geralmente com teores de matéria orgânica inferiores aos do sistema natural.

Existe uma estreita relação entre a matéria orgânica do solo e as partículas dos minerais de argila, formando complexos organominerais (Mortland, 1986; Schnitzer, 1986). Solos com maior conteúdo de argila tem maior poder de conservação e estabilização da matéria orgânica (Feller, 1995; Lepsch et al., 1982). Porém, devido à complexidade da associação organomineral, o estudo da matéria orgânica do solo tem sido feito, tradicionalmente, de acordo com um enfoque bioquímico, procurando-se minimizar o conteúdo de cinzas, enquanto que o estudo dos minerais é feito, geralmente, depois da eliminação da matéria orgânica (Christensen, 1992).

$\mathrm{O}$ fracionamento fisico do solo, de acordo com o tamanho das partículas ou por densidade (Christensen, 1992) tem se mostrado uma ferramenta útil no estudo da matéria orgânica do solo, revelando diferenças tanto na estrutura como nas propriedades dinâmicas da matéria orgânica quando ligada às partículas de diferentes tamanhos. Esta metodologia não causa a desestruturação da matéria orgânica, pois separa o componentes ainda não decompostos, e permite estudar as associações organo-minerais, bem como o balanço de nutrientes como $\mathrm{C}, \mathrm{N}, \mathrm{P}$ e $\mathrm{S}$ nos diversos tamanhos de partículas e as alterações nestes balanços provocadas pelo cultivo e manejo do solo. Pela possibilidade de localização dos componentes orgânicos de acordo com o tamanho das partículas do solo, é possível estudar também, com maior detalhe, o papel da matéria orgânica na microagregação do solo. Estudos de fracionamento químico subsequentes ao fracionamento granulométrico podem ser realizados e fornecem informações mais precisas sobre o tipo de componente orgânico que está associado a cada uma das frações determinadas.

Estudos realizados por Feller (1995b) com microscopia ótica e eletrônica de transmissão permitiram observar que as frações de tamanho superior a $20 \mu \mathrm{m}$ (fração "resíduos vegetais") são dominadas por resíduos de folhas e raízes com estrutura mais ou menos reconhecível, sendo que os de menor tamanho são menos estruturados, podendo 
estar partidos pela ação de fungos, e resíduos orgânicos aparentemente mais humificados e de aspecto semelhante a carvão. A fração 2-20 $\mu \mathrm{m}$ ("organo-siltosa") é constituída de microagregados $(1-5 \mu \mathrm{m})$ formados essencialmente por empilhamento de filitos e paredes vegetais ou micélios decompostos. A fração 0-2 $\mu \mathrm{m}$ (“organo-argilosa") é dominada por constituintes minerais (filitos e óxidos de ferro) mas há também a presença de restos de paredes vegetais, bactérias mais ou menos desestruturadas e material orgânico não discernível (amorfo).

Muitos trabalhos têm demonstrado que quando o teor total de carbono do solo muda, as concentrações em carbono das partículas de tamanhos diferentes são afetadas de forma diversa, indicando que a matéria orgânica do solo tem períodos diferenciados de "turn-over", dependendo do tipo de partícula à qual ela se liga (Cerri et al., 1985; Feller et al., 1993).

Dalal \& Mayer (1986) estudaram o teor de matéria orgânica das partículas de vários tamanhos de seis solos da Austrália, com diversas texturas, em estado virgem e submetidos a cultivo durante 20 a 70 anos. Para todos os solos virgens a proporção de matéria orgânica da fração argila situou-se em torno de 48 \% e para as frações silte e areia ficou em $26 \%$. Com o cultivo de cereais, o teor de matéria orgânica de todas as frações diminuiu com o período de cultivo, sendo maiores as perdas na fração areia para todos os solos. Em conseqüência, a proporção do carbono orgânico da fração argila foi aumentada com o tempo de cultivo em relação ao estado inicial. A perda do material orgânico das partículas da fração areia foi devida principalmente ao fato de que o material orgânico desta fração é composto principalmente por resíduos vegetais ainda não decompostos e hifas de fungos, e portanto, mais suscetíveis à oxidação e à desintegração pelo cultivo. A perda da matéria orgânica das frações argila e silte deve-se provavelmente às perdas de massa microbiana e seus resíduos.

Adams (1982) avaliou as diferenças entre a distribuição de C e $\mathrm{N}$ nas frações de dois solos da Irlanda do Norte quando submetido à pastagem natural, pastagem mais esterco líquido de porco ou gado, ou sob cultivo contínuo por 1; 2; 9 e 33 anos. De maneira geral, as frações de menor tamanho $(0,03-0,2 \mu \mathrm{m})$ possuíam as maiores 
proporções do carbono e nitrogênio totais. $\mathrm{O}$ solo sob pastagem natural apresentou maior concentração de carbono em todas as frações e essa diferença foi acentuada com o aumento do tempo de cultivo. O esterco bovino aumentou o carbono em todas as frações, sobretudo na fração areia $(20-2.000 \mu \mathrm{m})$ e coloidal $(<0,03 \mu \mathrm{m})$, enquanto que o esterco suíno aumentou o $\mathrm{C}$ apenas na fração argila.

Feller et al. (1983) estudaram o efeito da incorporação de palha sobre a matéria orgânica das frações granulométricas de um solo arenoso do Senegal. A fração menor que $50 \mu \mathrm{m}$ foi responsável pela maior parte do carbono $(51,4 \%)$ e do nitrogênio (62,2 \%) total do solo e a seguir situou-se a fração 50-200 $\mu \mathrm{m}$, com $31.6 \%$ do C e 23.9 $\%$ do nitrogênio. Com a adição da palha ocorreu um aumento médio de $30 \%$ para os teores dos dois elementos no solo total, mas este incremento não foi uniforme entre as frações. A fração organo-mineral menor que $50 \mu \mathrm{m}$ teve uma variação praticamente nula enquanto que as frações 50-200 e 200-2.000 $\mu \mathrm{m}$ foram as principais responsáveis pelo aumento da matéria orgânica do solo. A relação $\mathrm{C} / \mathrm{N}$ foi pouco afetada pela adição da palha, com valores de 28; 15,7; 11,5; 7,2 para as frações $>2.000,200-2.000,50-200 \mathrm{e}<$ $50 \mu \mathrm{m}$, respectivamente.

Feller (1988) avaliou a influência de sistemas de uso da terra (pastagem, pousio, culturas hortícolas, rotação de culturas) por sete a dez anos sobre o estoque orgânico nas frações de solos das Antilhas. Para os sistemas de cultura observou-se que a maior variação entre os valores de carbono orgânico ocorreram nas frações 0-5 e >50 $\mu \mathrm{m}$. As frações organo-siltosas sofreram pouca influência do sistema de cultivo, e as maiores transformações (perdas) ocorreram nos resíduos vegetais (>50 $\mu \mathrm{m})$ e nas exudações microbianas e radiculares $(0-5 \mu \mathrm{m})$.

A maior resistência às transformações da fração silte da matéria orgânica foi também observada, na Dinamarca, por Christensen (1987), que estudou a taxa de decomposição da matéria orgânica associada às diferentes partículas de um solo arenoso e de um areno siltoso com incorporação ou queima de palha. As partículas analisadas foram argila $(<2 \mu \mathrm{m})$, silte $(2-20 \mu \mathrm{m})$ e areia $(20-6.000 \mu \mathrm{m})$. $\mathrm{O}$ solo não fracionado e as partículas separadas foram incubados, sendo monitorada a liberação de $\mathrm{CO}_{2}$, a fim de 
determinar a taxa de decomposição da matéria orgânica, que foi mais alta no solo areno siltoso do que no arenoso. Para as frações de ambos os solos, as taxas de decomposição diferiram na seguinte ordem: areia $>$ argila $\geq$ solo total $>$ silte. A incorporação de palha aumentou ligeiramente o teor de carbono em todas as frações.

Feller (1993) avaliou a influência do clima e da textura do solo no estoque e na dinâmica da matéria orgânica do solo em oxissois da África, Antilhas e Brasil. Esse autor constatou que o estoque de carbono do solo foi muito mais determinado pelo teor de argila mais silte do que pelo clima, mesmo considerando o grande gradiente estudado (600 a $3.000 \mathrm{~mm} \mathrm{ano}^{-1}$ de chuva). Comparando o teor total de carbono do solo das várias situações estudadas, constatou-se uma redução de 30 a $40 \%$ quando o solo foi submetido ao cultivo, comparando-se com o solo não cultivado. Essa redução ocorreu em três anos para os solos arenosos e em dez anos para os argilo-arenosos. Quanto aos teores de carbono das frações, levando-se em consideração a textura do solo, observouse que para as frações $20-2.000 \mu \mathrm{m}$ os teores foram praticamente constantes ( 3 a $5 \mathrm{mg} \mathrm{C}$ $\mathrm{g}^{-1}$ solo) quaisquer que fossem os teores de argila. Para as frações 2-20 $\mu \mathrm{m}$ os teores aumentaram com o teor de argila ( 3 a $8 \mathrm{mg} \mathrm{C} \mathrm{g}^{-1}$ solo), sendo este aumento ainda maior para as frações 0-2 $\mathrm{mm}$ (3 a $17 \mathrm{mg} \mathrm{C}^{-1}$ solo). Quando o solo sob vegetação natural foi submetido ao cultivo as mudanças no estoque de carbono dependeram da textura do solo: para os arenosos a redução mais importante ocorreu na fração de resíduos vegetais (20$2.000 \mu \mathrm{m}$ ) enquanto que para solos siltosos a redução foi devida principalmente às frações silte $(2-20 \mu \mathrm{m})$ e para os argilosos a redução do carbono ocorreu principalmente na fração argilosa, seguida da fração resíduo vegetal e depois silte.

O objetivo deste trabalho foi de estudar o comportamento da matéria orgânica do solo através do fracionamento fisico, em um latossolo roxo de Londrina, PR submetido às seguintes situações: culturas anuais, mata nativa, pomar durante dez anos manejado com adubo verde permanente (Arachis prostrata Benth.), pomar com vegetação espontânea (predomínio de gramíneas) e pomar mantido limpo permanentemente através de capina. 


\section{4 Material e Métodos}

O clima da região de Londrina (PR), segundo a classificação de Köppen, é do tipo Cfa, subtropical úmido, com chuvas em todas as estações, podendo ocorrer seca no período de inverno (Corrêa et al., 1982). O solo estudado (Latossolo Roxo distrófico) está situado no campus da Universidade Estadual de Londrina. Pela análise granulométrica apresentou apresentou $691 \mathrm{~g} \mathrm{~kg}^{-1}$ de argila, $216 \mathrm{~g} \mathrm{~kg}^{-1}$ de silte e $93 \mathrm{~g} \mathrm{~kg}^{-1}$ de areia. A análise química do solo, de acordo com a metodologia descrita em Empresa Brasileira de Pesquisa Agropecuária (1979), realizada por ocasião da instalação do pomar revelou os seguintes valores para a camada de $0-15 \mathrm{~cm}$ : $\mathrm{pH}\left(\mathrm{H}_{2} \mathrm{O}\right)=5,38$; matéria orgânica $=29,2 \mathrm{~g} \mathrm{dm}^{-3} ; \mathrm{P}($ Mehlich-1 $)=2,04 \mathrm{mg} \mathrm{dm}^{-3} ; \mathrm{K}^{+}=2,3 \mathrm{mmol}_{\mathrm{c}} \mathrm{dm}^{-3} ; \mathrm{Ca}^{+2}=45$ $\operatorname{mmol}_{\mathrm{c}} \mathrm{dm}^{-3} ; \mathrm{Mg}^{+2}=19 \mathrm{mmol}_{\mathrm{c}} \mathrm{dm}^{-3} ; \mathrm{H}^{+}+\mathrm{Al}^{3+}=70 \mathrm{mmol}_{\mathrm{c}} \mathrm{dm}^{-3}$. Para a camada de 15-30 $\mathrm{cm}$, os resultados foram: $\mathrm{pH}\left(\mathrm{H}_{2} \mathrm{O}\right)=5,02$; matéria orgânica $=17,5 \mathrm{~g} \mathrm{dm}^{-3} ; \mathrm{P}($ Mehlich-1) $=0,92 \mathrm{mg} \mathrm{dm}{ }^{-3} ; \mathrm{K}^{+}=1,1 \mathrm{mmol}_{\mathrm{c}} \mathrm{dm}^{-3} ; \mathrm{Ca}^{+2}=33 \mathrm{mmol}_{\mathrm{c}} \mathrm{dm}^{-3} ; \mathrm{Mg}^{+2}=32 \mathrm{mmol}_{\mathrm{c}} \mathrm{dm}^{-3}$; $\mathrm{H}^{+}+\mathrm{Al}^{3+}=61 \mathrm{mmol}_{\mathrm{c}} \mathrm{dm}^{-3}$.

A área do pomar de citrus, antes cultivada com mandioca, foi condurida durante dez anos com um experimento de manejo de solo, nas entrelinhas das plantas cítricas. Todos os tratamentos recebem calcário dolomítico a cada 3-4 anos e adubação mineral (sulfato de amônio, superfosfato simples e cloreto de potássio) com base nos teores dos elementos no solo e nas produções médias anuais, de acordo com as recomendações do Grupo Paulista de Adubação e Calagem para Citros (1988).

Para o estudo foram selecionadas as parcelas pertencentes aos seguintes tratamentos: cobertura verde durante todo o ano com a leguminosa perene Arachis prostrata Benth.; uso alternado de uma gradagem a disco (no período seco) e de roçadeira (três a quatro vezes no período de chuvas); capina manual o ano inteiro. Foram retiradas também amostras do mesmo solo sob mata natural (floresta tropical subperenifólia) e sob cultura anual durante 20 anos (na safra em questão cultivou-se aveia 
no inverno após algodão no verão) em áreas localizadas ao lado do pomar. As amostragens foram realizadas a $0-10$ e $10-20 \mathrm{~cm}$ de profundidade.

A metodologia seguida para a execução do fracionamento granulométrico foi a descrita por Feller et al. (1991) e Gavinelli et al. (1995). Executou-se o fracionamento em amostras compostas, obtidas a partir da reunião das amostras provenientes das repetições (parcelas) no campo, peneiradas a 0-2 mm. Para o estudo utilizou-se $20 \mathrm{~g}$ de solo de cada amostra composta por seis subamostras coletadas a campo. Para facilitar a dispersão usou-se hexametafosfato de sódio $(0,5 \mathrm{~g} / 200 \mathrm{ml}$ de água), bolas de ágata e agitação rotativa $(50 \mathrm{rpm})$ por duas horas. As frações $200-2.000 \mu \mathrm{m}$ e 50-200 $\mu \mathrm{m}$ foram obtidas por peneiramento com o auxílio de água destilada e levadas à estufa $\left(60^{\circ} \mathrm{C}\right)$, até peso constante. Para aumentar a dispersão na obtenção das frações menor que $50 \mu \mathrm{m}$ utilizouse ultrasom (Balesdant et al., 1991). A fração 20 - $50 \mu \mathrm{m}$ foi obtida por peneiramento. A proporção da fração $0-20 \mu \mathrm{m}$ foi determinada através de uma alíquota retirada a até 10 $\mathrm{cm}$ da superficie da suspensão restante agitada previamente. Após 8 horas, a $20^{\circ} \mathrm{C}$, foi sifonada uma segunda alíquota, representando a fração 0-2 $\mu \mathrm{m}$ (Gavinelli et al., 1995). 0 cálculo da proporção de cada fração foi feito determinando-se a percentagem em relação ao peso total da amostra de solo. Para as frações $200-2.000 \mu \mathrm{m}, 50-200 \mu \mathrm{m}$ e $20-50 \mu \mathrm{m}$ calculou-se através da fórmula (Peso da fração . 100 )/ peso da amostra. Para as alíquotas as fórmulas utilizadas foram: (peso da fração . 1000 . 100)/ vol alíquota. peso da amostra. As frações obtidas (0-2, 2-20, 20-50 e 50-200 e 200-2.000 $\mu \mathrm{m})$ foram analisadas para a determinação dos teores de carbono e nitrogênio, em $\mathrm{mg} \mathrm{g}^{-1}$ de fração (Analisador Elementar CHN - Carlo Erba) no ORSTOM, Montpellier, França. O conteúdo de carbono e nitrogênio das frações (em $\mathrm{mg} \mathrm{g}^{-1}$ de solo) foi calculado considerando-se a massa de cada fração. $\mathrm{O}$ estoque de carbono (em $\mathrm{Mg} \mathrm{ha}^{-1}$ ) foi obtido por cálculo considerando a camada e densidade do solo (a partir dos resultados do item 4 desta tese). 


\section{5 Resultados e Discussão}

Os resultados das análises de teores de carbono e nitrogênio no solo não fracionado - NF (em $\mathrm{mg} \mathrm{g}^{-1}$ de solo), por fração (em $\mathrm{mg} \mathrm{g}^{-1}$ de fração e $\mathrm{mg} \mathrm{g}^{-1}$ de solo), estoque de carbono (em Mg ha ${ }^{-1}$ ), contribuição (em \%) de cada fração sobre o total de C e N do solo e relação C/N são apresentados nas Tabelas 19 a 28 e Figuras 25 a 32.

Em um levantamento da matéria orgânica dos solos do Estado de São Paulo (camada 0-20 cm) Lepsch et al. (1994) calcularam equações de regressão levando em consideração a vegetação nativa, o uso da terra, o clima e o teor de argila mais silte. Para as condições do presente estudo (floresta semi-decídua, clima údico, teor de argila mais silte de 90,7 \%) e ajustando os valores inicialmente calculados em base de volume para a expressão em massa (considerando as densidades do solo apresentadas no item 4 desta tese) as equações indicaram um valor de $36,4 \mathrm{mg} \mathrm{g}^{-1}$ de $\mathrm{C}$ sob a vegetação natural e de $24,2 \mathrm{mg} \mathrm{g}^{-1}$ de $\mathrm{C}$ sob cultivo. Quando na equação foi adicionada a variável teor de carbono do solo sob vegetação nativa, o valor calculado para a situação de cultura foi de $20,4 \mathrm{mg} \mathrm{g}^{-1}$ de C. Os valores aqui determinados para o solo $\mathrm{NF}$ foram de $31,9 \mathrm{mg} \mathrm{g}^{-1} \mathrm{de}$ $\mathrm{C}$ e de $17,7 \mathrm{mg} \mathrm{g}^{-1}$ de $\mathrm{C}$, respectivamente, para mata nativa e cultura anual por 20 anos, na camada 0-10 cm, indicando que estão próximos da estimativa de Lepsch et al. (1994). Os valores encontrados para as condições do pomar, observa-se que este apresentou valores de $\mathrm{C}$ intermediários entre a vegetação nativa e o cultivo anual. $\mathrm{O}$ uso de plantas de cobertura (tanto leguminosas como gramíneas) manteve o carbono em níveis mais elevados do que o solo descoberto através de capina permanente, favorecendo a durabilidade do sistema produtivo (Feller, 1995a), apesar dos resultados relativos à produção de frutos do pomar não terem apresentado diferenças significativas (item 3 da presente tese).

Os teores totais de carbono na camada $0-10 \mathrm{~cm}$ no presente trabalho foram superiores aos encontrados por Freitas et al. (1997) em um latossolo vermelho escuro argiloso (36 a $51 \%$ de argila) em Goiás. Esses autores obtiveram de 19,0 (sob pastagem) 
Tabela 19. Características das frações granulométricas da matéria orgânica do solo sob mata natural $(\mathrm{MN})$, na profundidade de $0-10 \mathrm{~cm}$.

\begin{tabular}{|c|c|c|c|c|c|c|c|c|}
\hline \multirow{2}{*}{$\begin{array}{l}\text { Fração } \\
\qquad(\mu \mathrm{m})\end{array}$} & \multirow{2}{*}{$\begin{array}{c}\text { Massa } \\
(\%)\end{array}$} & \multicolumn{4}{|c|}{$\mathrm{C}$} & \multicolumn{2}{|c|}{$\mathrm{N}$} & \multirow[t]{2}{*}{$\mathrm{C} / \mathrm{N}$} \\
\hline & & $\begin{array}{l}\mathrm{mg} \mathrm{g}^{-1} \\
\text { fração }\end{array}$ & $\begin{array}{l}\mathrm{mg} \mathrm{g}^{-1} \\
\text { solo }\end{array}$ & $\begin{array}{l}\% \text { do } \\
\text { total }\end{array}$ & $\begin{array}{l}\text { estoque } \\
\mathrm{Mg} \mathrm{ha}^{-1}\end{array}$ & $\begin{array}{l}\mathrm{mg} \mathrm{g} \\
\text { fração }\end{array}$ & $\begin{array}{l}\mathrm{mg} \mathrm{g}^{-1} \\
\text { solo }\end{array}$ & \\
\hline $200-2.000$ & 2,20 & 118,1 & 2,60 & 8,6 & 2,21 & 9,49 & 0,209 & 12,4 \\
\hline $50-200$ & 11,84 & 37,4 & 4,43 & 14,6 & 3,76 & 3,49 & 0,413 & 10,7 \\
\hline $20-50$ & 2,77 & 27,2 & 0,75 & 2,5 & 0,64 & 2,05 & 0,057 & 13,3 \\
\hline $20-2.000$ & 16,81 & 46,28 & 7,78 & 25,7 & 6,61 & 4,04 & 0,679 & 11,5 \\
\hline $2-20$ & 19,55 & 36,2 & 7,07 & 23,4 & 6,01 & 3,61 & 0,705 & 10,0 \\
\hline $0-2$ & 57,62 & 18,0 & 10,37 & 34,3 & 8,82 & 1,91 & 1,101 & 9,4 \\
\hline W(mg/l) & & & 5,03 & 16,6 & 4,28 & & & \\
\hline total & $93, \overline{98}$ & & 30,25 & & 25,71 & & 2,485 & 12,2 \\
\hline solo NF & 100,00 & & 31,90 & & 27,12 & & 3,090 & 10,3 \\
\hline
\end{tabular}

W: Carbono solúvel em água

Tabela 20. Características das frações granulométricas da matéria orgânica do solo sob mata natural $(\mathrm{MN})$, na profundidade de $10-20 \mathrm{~cm}$.

\begin{tabular}{|c|c|c|c|c|c|c|c|c|}
\hline \multirow{2}{*}{$\begin{array}{l}\text { Fração } \\
\quad(\mu \mathrm{m})\end{array}$} & \multirow{2}{*}{$\begin{array}{l}\text { Massa } \\
(\%)\end{array}$} & \multicolumn{4}{|c|}{ C } & \multicolumn{2}{|l|}{$\mathrm{N}$} & \multirow[t]{2}{*}{$\mathrm{C} / \mathrm{N}$} \\
\hline & & $\begin{array}{l}\mathrm{mg} \mathrm{g}^{-1} \\
\text { fração }\end{array}$ & $\begin{array}{l}\mathrm{mg} \mathrm{g}^{-1} \\
\text { solo }\end{array}$ & $\begin{array}{l}\% \text { do } \\
\text { total }\end{array}$ & $\begin{array}{l}\text { estoque } \\
\mathrm{Mg} \mathrm{ha}^{-1}\end{array}$ & $\begin{array}{l}\text { mg } \mathrm{g}^{-1} \\
\text { fração }\end{array}$ & $\begin{array}{l}\mathrm{mg} \mathrm{g}^{-1} \\
\text { solo }\end{array}$ & \\
\hline $200-2.000$ & 0,44 & 111,0 & 0,49 & 2,9 & $0, \overline{46}$ & $\overline{6}, \overline{7}$ & 0,030 & 16,4 \\
\hline $50-200$ & 5,97 & 31,9 & 1,90 & 11,2 & 1,81 & 2,01 & 0,120 & 15,9 \\
\hline $20-50$ & 3,13 & 14,2 & 0,44 & 2,6 & 0,42 & 0,87 & 0,027 & 16,3 \\
\hline $20-2.000$ & 9,54 & 30,58 & 2,83 & 16,7 & 2,69 & 1,86 & 0,447 & $\overline{16,44}$ \\
\hline $2-20$ & 13,51 & 18,3 & 2,47 & 14,6 & 2,34 & 1,65 & 0,223 & 11,1 \\
\hline $0-2$ & 65,45 & 13,0 & 8,51 & 50,3 & 8,08 & 1,36 & 0,890 & 9,6 . \\
\hline $\mathrm{W}(\mathrm{mg} / \mathrm{l})$ & & & 3,12 & 18,4 & 2,96 & & & \\
\hline total & 88,50 & & 16,93 & 100,0 & 16,08 & & 1,290 & 13,1 \\
\hline solo NF & 100,00 & & 20,00 & & 19,00 & & 1,744 & 11,5 \\
\hline
\end{tabular}

W: Carbono solúvel em água 
Tabela 21. Características das frações granulométricas da matéria orgânica do solo sob cultura anual (CA), na profundidade de $0-10 \mathrm{~cm}$.

\begin{tabular}{|c|c|c|c|c|c|c|c|c|}
\hline \multirow{2}{*}{$\begin{array}{l}\text { Fração } \\
\qquad(\mu \mathrm{m})\end{array}$} & \multirow{2}{*}{$\begin{array}{c}\text { Massa } \\
(\%)\end{array}$} & \multicolumn{4}{|c|}{ C } & \multicolumn{2}{|c|}{$\mathrm{N}$} & \multirow[t]{2}{*}{$\mathrm{C} / \mathrm{N}$} \\
\hline & & $\begin{array}{l}\mathrm{mg} \mathrm{g}^{-1} \\
\text { fração }\end{array}$ & $\begin{array}{l}\mathrm{mg} \mathrm{g}^{-1} \\
\text { solo }\end{array}$ & $\begin{array}{l}\% \text { do } \\
\text { total }\end{array}$ & $\begin{array}{l}\text { estoque } \\
\mathrm{Mg} \mathrm{ha}^{-1}\end{array}$ & $\begin{array}{l}\mathrm{mg} \mathrm{g} \\
\text { fração }\end{array}$ & $\begin{array}{l}\mathrm{mg} \mathrm{g}^{-1} \\
\text { solo }\end{array}$ & \\
\hline $200-2.000$ & 0,67 & 71,9 & 0,48 & 2,6 & $0, \overline{49}$ & $4, \overline{16}$ & 0,028 & 17,3 \\
\hline $50-200$ & 6,39 & 26,2 & 1,67 & 9,0 & 1,71 & 1,73 & 0,110 & 15,1 \\
\hline $20-50$ & 3,71 & 14,4 & 0,53 & 2,9 & 0,54 & 0,93 & 0,034 & 15,5 \\
\hline $20-2.000$ & 10,77 & 24,98 & 2,68 & 14,5 & 2,74 & 1,61 & 0,172 & 15,5 \\
\hline $2-20$ & 19,68 & 25,2 & 4,96 & 26,7 & 5,06 & 2,32 & 0,456 & 10,9 \\
\hline $0-2$ & 67,62 & 11,9 & 8,05 & 43,3 & 8,21 & 1,34 & 0,906 & 8,9 \\
\hline W(mg/l) & & & 2,90 & 15,6 & 2,96 & & & \\
\hline total & 98,06 & & 18,60 & 100,0 & 18,97 & & 1,535 & 12,1 \\
\hline solo NF & 100,00 & & 17,70 & & 18,05 & & 1,670 & 10,6 \\
\hline
\end{tabular}

W: Carbono solúvel em água

Tabela 22. Características das frações granulométricas da matéria orgânica do solo sob cultura anual (CA), na profundidade de $10-20 \mathrm{~cm}$.

\begin{tabular}{|c|c|c|c|c|c|c|c|c|}
\hline \multirow{2}{*}{$\begin{array}{l}\text { Fração } \\
\quad(\mu \mathrm{m})\end{array}$} & \multirow{2}{*}{$\begin{array}{c}\text { Massa } \\
\text { (\%) }\end{array}$} & \multicolumn{4}{|c|}{$\mathrm{C}$} & \multicolumn{2}{|c|}{$\overline{\mathbf{N}}$} & \multirow[t]{2}{*}{$\bar{C} / \mathrm{N}$} \\
\hline & & $\begin{array}{l}\mathrm{mg} \mathrm{g}^{-1} \\
\text { fração }\end{array}$ & $\begin{array}{l}\mathrm{mg} \mathrm{g}^{-1} \\
\text { solo }\end{array}$ & $\begin{array}{l}\% \text { do } \\
\text { total }\end{array}$ & $\begin{array}{l}\text { estoque } \\
\mathrm{Mg} \mathrm{ha}^{-1}\end{array}$ & $\begin{array}{l}\mathrm{mg} \mathrm{g}^{-1} \\
\text { fração }\end{array}$ & $\begin{array}{l}\mathrm{mg} \mathrm{g}^{-1} \\
\text { solo }\end{array}$ & \\
\hline $200-2.000$ & 0,67 & 64,3 & 0,43 & 2,7 & 0,51 & 3,00 & 0,020 & 21,4 \\
\hline $50-200$ & 5,30 & 17,5 & 0,93 & 5,9 & 1,09 & 1,06 & 0,056 & 16,5 \\
\hline $20-50$ & 3,05 & 13,9 & 0,42 & 2,7 & 0,50 & 0,86 & 0,026 & 16,2 \\
\hline $20-2.000$ & 9,02 & 19,76 & 1,78 & 11,3 & 2,1 & 1,14 & 0,102 & 17,3 \\
\hline $2-20$ & 17,06 & 23,5 & 4,00 & 25,3 & 4,72 & 2,06 & 0,352 & 11,4 \\
\hline $0-2$ & 67,35 & 11,1 & 7,48 & 47,2 & 8,82 & 1,22 & 0,822 & 9,1 \\
\hline $\mathrm{W}(\mathrm{mg} / \mathrm{l})$ & & & 2,59 & 16,4 & 3,06 & & & 9,8 \\
\hline total & 93,42 & & 15,85 & 100,0 & 18,70 & & 1,276 & 12,4 \\
\hline solo NF & 100,00 & & 16,80 & & 19,82 & & 1,613 & 10,4 \\
\hline
\end{tabular}

W: Carbono solúvel em água 
Tabela 23. Características das frações granulométricas da matéria orgânica do solo sob cobertura de Arachis prostrata (A), na profundidade de $0-10 \mathrm{~cm}$.

\begin{tabular}{|c|c|c|c|c|c|c|c|c|}
\hline \multirow{2}{*}{$\begin{array}{l}\text { Fração } \\
\qquad(\mu \mathrm{m})\end{array}$} & \multirow{2}{*}{$\begin{array}{c}\text { Massa } \\
(\%)\end{array}$} & \multicolumn{4}{|c|}{$\bar{C}$} & \multicolumn{2}{|c|}{$\mathbf{N}$} & \multirow[t]{2}{*}{$\mathrm{C} / \mathrm{N}$} \\
\hline & & $\begin{array}{l}\mathrm{mg} \mathrm{g}^{-1} \\
\text { fração }\end{array}$ & $\begin{array}{c}\mathrm{mg} \mathrm{g}^{-1} \\
\text { solo }\end{array}$ & $\begin{array}{l}\% \text { do } \\
\text { total }\end{array}$ & $\begin{array}{l}\text { estoque } \\
\mathrm{Mg} \mathrm{ha}^{-1}\end{array}$ & $\begin{array}{l}\mathrm{mg} \mathrm{g}^{-1} \\
\text { fração }\end{array}$ & $\begin{array}{l}\mathrm{mg} \mathrm{g}^{-1} \\
\text { solo }\end{array}$ & \\
\hline $200-2.000$ & 0,94 & 102,4 & 0,96 & 3,9 & $1, \overline{18}$ & 6,91 & 0,065 & 14,8 \\
\hline $50-200$ & 9,05 & 26,7 & 2,42 & 9,9 & 2,95 & 2,11 & 0,191 & 12,7 \\
\hline $20-50$ & 3,42 & 28,7 & 0,98 & 4,0 & 1,20 & 1,84 & 0,063 & 15,6 \\
\hline $20-2.000$ & 13,41 & 32,52 & 4,36 & 17,8 & 5,33 & 2,38 & 0,319 & 13,7 \\
\hline $2-20$ & 18,89 & 35,6 & 6,47 & 27,5 & 8,22 & 3,21 & 0,607 & 11,1 \\
\hline $0-2$ & 66,74 & 14,8 & 9,88 & 40,4 & 12,05 & 1,67 & 1,115 & 8,9 \\
\hline $\mathrm{W}(\mathrm{mg} / \mathrm{l})$ & & & 3,49 & 14,3 & 4,26 & & & \\
\hline total & 99,04 & & 24,46 & 100,0 & 29,84 & & 2,040 & 12,0 \\
\hline solo NF & 100,00 & & 23,60 & & 28,79 & & 2,519 & 9,4 \\
\hline
\end{tabular}

W: Carbono solúvel em água

Tabela 24. Características das frações granulométricas da matéria orgânica do solo sob cobertura de Arachis prostrata (A), na profundidade de $10-20 \mathrm{~cm}$.

\begin{tabular}{|c|c|c|c|c|c|c|c|c|}
\hline \multirow{2}{*}{$\begin{array}{l}\text { Fração } \\
\qquad(\mu \mathrm{m})\end{array}$} & \multirow{2}{*}{$\begin{array}{c}\text { Massa } \\
(\%)\end{array}$} & \multicolumn{4}{|c|}{ C } & \multicolumn{2}{|l|}{$\mathrm{N}$} & \multirow[t]{2}{*}{$\mathrm{C} / \mathrm{N}$} \\
\hline & & $\begin{array}{l}\mathrm{mg} \mathrm{g}^{-1} \\
\text { fração }\end{array}$ & $\begin{array}{l}\mathrm{mg} \mathrm{g}^{-1} \\
\text { solo }\end{array}$ & $\begin{array}{l}\% \text { do } \\
\text { total }\end{array}$ & $\begin{array}{l}\text { estoque } \\
\mathrm{Mg} \mathrm{ha}^{-1}\end{array}$ & $\begin{array}{l}\text { mg } \mathrm{g}^{-1} \\
\text { fração }\end{array}$ & $\begin{array}{c}\mathrm{mg} \mathrm{g}^{-1} \\
\text { solo }\end{array}$ & \\
\hline $200-2.000$ & 0,85 & 65,5 & 0,56 & 2,8 & 0,70 & 3,02 & 0,026 & 21,7 \\
\hline $50-200$ & 8,12 & 13,8 & 1,12 & 5,7 & 1,40 & 0,99 & 0,080 & 13,9 \\
\hline $20-50$ & 3,45 & 18,8 & 0,65 & 3,3 & 0,81 & 1,16 & 0,040 & 16,2 \\
\hline $20-2.000$ & 12,42 & 18,73 & 2,33 & 11,8 & 2,91 & 1,18 & 0,146 & 15,9 \\
\hline $2-20$ & 18,86 & 25,7 & 4,86 & 24,5 & 6,07 & 2,24 & 0,422 & 11,5 \\
\hline $0-2$ & 67,79 & 13,8 & 9,36 & 47,3 & 11,69 & 1,55 & 1,051 & 8,9 \\
\hline $\mathrm{W}(\mathrm{mg} / \mathrm{l})$ & & & 3,25 & 16,4 & 4,06 & & & \\
\hline total & 99,07 & & 19,79 & 100,0 & 24,73 & & & 12,2 \\
\hline solo NF & 100,00 & & 19,10 & & 23,87 & & & 10,4 \\
\hline
\end{tabular}

W: Carbono solúvel em água 
Tabela 25. Características das frações granulométricas da matéria orgânica do solo de pomar manejado com Grade/Roçadeira (GR), na profundidade de $0-10 \mathrm{~cm}$.

\begin{tabular}{|c|c|c|c|c|c|c|c|c|}
\hline \multirow{2}{*}{$\begin{array}{l}\text { Fração } \\
\qquad(\mu \mathrm{m})\end{array}$} & \multirow{2}{*}{$\begin{array}{c}\text { Massa } \\
(\%)\end{array}$} & \multicolumn{4}{|c|}{ C } & \multicolumn{2}{|c|}{$\mathrm{N}$} & \multirow[t]{2}{*}{$\mathrm{C} / \mathrm{N}$} \\
\hline & & $\begin{array}{l}\mathrm{mg} \mathrm{g}^{-1} \\
\text { fração }\end{array}$ & $\begin{array}{l}\mathrm{mg} \mathrm{g}^{-1} \\
\text { solo }\end{array}$ & $\begin{array}{l}\% \text { do } \\
\text { total }\end{array}$ & $\begin{array}{l}\text { estoque } \\
\mathrm{Mg} \mathrm{ha}^{-1}\end{array}$ & $\begin{array}{l}\mathrm{mg} \mathrm{g} \\
\text { fração }\end{array}$ & $\begin{array}{c}\mathrm{mg} \mathrm{g}^{-1} \\
\text { solo }\end{array}$ & \\
\hline $200-2.000$ & 1,47 & 71,0 & 1,04 & 4,6 & $1, \overline{31}$ & 3,66 & 0,054 & 19,4 \\
\hline $50-200$ & 8,39 & 29,4 & 2,47 & 10,8 & 3,11 & 2,08 & 0,175 & 14,1 \\
\hline $20-50$ & 3,12 & 15,0 & 0,47 & 2,1 & 0,59 & 0,93 & 0,029 & 16,1 \\
\hline $20-2.000$ & 12,98 & 30,65 & 3,98 & 17,5 & 5,01 & 1,98 & 0,258 & 15,5 \\
\hline $2-20$ & 18,34 & 34,3 & 6,29 & 27,6 & 7,93 & 3,03 & 0,555 & 11,3 \\
\hline $0-2$ & 62,58 & 14,9 & 9,33 & 41,0 & 11,75 & 1,57 & 0,983 & 9,5 \\
\hline $\mathrm{W}(\mathrm{mg} / \mathrm{l})$ & & & 3,17 & 13,9 & 3,99 & & & \\
\hline total & 93,91 & & 22,77 & 100,0 & 28,69 & & 1,795 & 12,7 \\
\hline solo NF & 100,00 & & 24,90 & & 31,37 & & 2,302 & 10,8 \\
\hline
\end{tabular}

W: Carbono solúvel em água

Tabela 26. Características das frações granulométricas da matéria orgânica do solo de pomar manejado com Grade/Roçadeira (GR), na profundidade de $10-20 \mathrm{~cm}$.

\begin{tabular}{|c|c|c|c|c|c|c|c|c|}
\hline \multirow{2}{*}{$\begin{array}{l}\text { Fração } \\
\qquad(\mu \mathrm{m})\end{array}$} & \multirow{2}{*}{$\begin{array}{c}\text { Massa } \\
(\%)\end{array}$} & \multicolumn{4}{|c|}{$\mathrm{C}$} & \multicolumn{2}{|l|}{$\bar{N}$} & \multirow[t]{2}{*}{$\mathrm{C} / \mathrm{N}$} \\
\hline & & $\begin{array}{l}\mathrm{mg} \mathrm{g}^{-1} \\
\text { fração }\end{array}$ & $\begin{array}{l}\mathrm{mg} \mathrm{g}^{-1} \\
\text { solo }\end{array}$ & $\begin{array}{l}\% \text { do } \\
\text { total }\end{array}$ & $\begin{array}{l}\text { estoque } \\
\mathrm{Mg} \mathrm{ha}^{-1}\end{array}$ & $\begin{array}{l}\mathrm{mg} \mathrm{g} \mathrm{g}^{-1} \\
\text { fração }\end{array}$ & $\begin{array}{l}\mathrm{mg} \mathrm{g} \\
{ }^{2} \text { solo }\end{array}$ & \\
\hline $200-2.000$ & 1,05 & 54,5 & 0,57 & 3,0 & $0, \overline{69}$ & 1,77 & 0,019 & 30,8 \\
\hline $50-200$ & 7,47 & 13,1 & 0,98 & 5,1 & 1,18 & 0,86 & 0,064 & 15,2 \\
\hline $20-50$ & 3,42 & 17,6 & 0,60 & 3,2 & 0,73 & 1,08 & 0,037 & 16,3 \\
\hline $20-2.000$ & 11,94 & 18,03 & 2,15 & 11,3 & 2,60 & 1,00 & 0,120 & 18,0 \\
\hline $2-20$ & 21,02 & 23,6 & 4,96 & 26,0 & 6,00 & 2,33 & 0,489 & 10,1 \\
\hline $0-2$ & 68,12 & 13,0 & 8,86 & 46,5 & 10,71 & 1,52 & 1,035 & 8,6 \\
\hline $\mathrm{W}(\mathrm{mg} / \mathrm{l})$ & & & 3,08 & 16,2 & 3,73 & & & \\
\hline total & 101,07 & & 19,05 & 100,0 & 23,05 & & 1,644 & 11,6 \\
\hline solo NF & 100,00 & & 19,50 & & 23,60 & & 1,798 & 10,8 \\
\hline
\end{tabular}

W: Carbono solúvel em água 
Tabela 27. Características das frações granulométricas da matéria orgânica do solo de pomar manejado com Capina (C), na profundidade de $0-10 \mathrm{~cm}$.

\begin{tabular}{|c|c|c|c|c|c|c|c|c|}
\hline \multirow{2}{*}{$\begin{array}{l}\text { Fração } \\
(\mu \mathrm{m})\end{array}$} & \multirow{2}{*}{$\begin{array}{c}\text { Massa } \\
(\%)\end{array}$} & \multicolumn{4}{|c|}{$\mathrm{C}$} & \multicolumn{2}{|l|}{$\mathbf{N}$} & \multirow[t]{2}{*}{$\mathrm{C} / \mathrm{N}$} \\
\hline & & $\begin{array}{l}\mathrm{mg} \mathrm{g}^{-1} \\
\text { fração }\end{array}$ & $\begin{array}{c}\mathrm{mg} \mathrm{g}^{-1} \\
\text { solo }\end{array}$ & $\begin{array}{l}\% \text { do } \\
\text { total }\end{array}$ & $\begin{array}{l}\text { estoque } \\
\mathrm{Mg} \mathrm{ha}^{-1}\end{array}$ & $\begin{array}{l}\text { mg } \mathrm{g}^{-1} \\
\text { fração }\end{array}$ & $\begin{array}{c}\mathrm{mg} \mathrm{g}^{-1} \\
\text { solo }\end{array}$ & \\
\hline $200-2.000$ & 0,97 & 53,3 & 0,52 & 2,8 & $0, \overline{63}$ & $2, \overline{13}$ & 0,021 & 25,0 \\
\hline $50-200$ & 8,47 & 16,4 & 1,39 & 7,6 & 1,68 & 1,24 & 0,105 & 13,2 \\
\hline $20-50$ & 3,31 & 14,7 & 0,49 & 2,7 & 0,59 & 0,96 & 0,032 & 15,3 \\
\hline $20-2.000$ & 12,75 & 18,76 & 2,40 & 13,1 & 2,9 & 1,24 & 0,158 & 15,1 \\
\hline $2-20$ & 20,66 & 25,2 & 5,21 & 28,5 & 6,30 & 2,48 & 0,512 & 10,2 \\
\hline $0-2$ & 67,70 & 11,1 & 7,51 & 41,1 & 9,09 & 1,24 & 0,839 & 9,0 \\
\hline $\mathrm{W}(\mathrm{mg} / \mathrm{l})$ & & & 3,16 & 17,3 & 3,82 & & & \\
\hline total & 101,12 & & 18,28 & 100,0 & 22,12 & & $\overline{1,509}$ & 12,1 \\
\hline solo NF & 100,00 & & 26,30 & & 31,82 & & 1,695 & 15,5 \\
\hline
\end{tabular}

W: Carbono solúvel em água

Tabela 28. Características das frações granulométricas da matéria orgânica do solo de pomar manejado com Capina (C), na profundidade de $10-20 \mathrm{~cm}$.

\begin{tabular}{|c|c|c|c|c|c|c|c|c|}
\hline \multirow{2}{*}{$\begin{array}{l}\text { Fração } \\
\text { (رm) }\end{array}$} & \multirow{2}{*}{$\begin{array}{c}\text { Massa } \\
(\%)\end{array}$} & \multicolumn{4}{|c|}{$\mathrm{C}$} & \multicolumn{2}{|l|}{$\mathrm{N}$} & \multirow[t]{2}{*}{$\mathrm{C} / \mathrm{N}$} \\
\hline & & $\begin{array}{l}\mathrm{mg} \mathrm{g}^{-1} \\
\text { fração }\end{array}$ & $\begin{array}{c}\mathrm{mg} \mathrm{g}^{-1} \\
\text { solo }\end{array}$ & $\begin{array}{l}\% \text { do } \\
\text { total }\end{array}$ & $\begin{array}{l}\text { estoque } \\
\mathrm{Mg} \mathrm{ha}^{-1}\end{array}$ & $\begin{array}{l}\text { mg } \mathrm{g}^{-1} \\
\text { fração }\end{array}$ & $\begin{array}{l}\mathrm{mg} \mathrm{g}^{-1} \\
\text { solo }\end{array}$ & \\
\hline $200-2.000$ & 0,73 & 34,7 & 0,25 & 1,4 & $0, \overline{31}$ & 1,36 & 0,010 & 25,5 \\
\hline $50-200$ & 7,46 & 14,2 & 1,06 & 6,0 & 1,29 & 0,92 & 0,069 & 15,4 \\
\hline $20-50$ & 3,33 & 8,1 & 0,27 & 1,5 & 0,33 & 0,54 & 0,018 & 15,0 \\
\hline $20-2.000$ & 11,52 & 13,74 & 1,58 & 8,9 & 1,93 & 0,84 & 0,097 & 16,4 \\
\hline $2-20$ & 19,03 & 24,5 & 4,67 & 26,6 & 5,70 & 2,26 & 0,430 & 10,9 \\
\hline $0-2$ & 68,26 & 11,7 & 7,99 & 45,5 & 9,74 & 1,39 & 0,949 & 8,4 \\
\hline$W(m g / 1)$ & & & 3,32 & 18,91 & 4,05 & & & \\
\hline total & 98,81 & & 17,56 & 100,0 & 21,42 & & 1,476 & 11,9 \\
\hline solo NF & 100,00 & & 21,40 & & 26,11 & & 1,746 & 12,3 \\
\hline
\end{tabular}

W: Carbono solúvel em água 
a 22,6 $\mathrm{mg} \mathrm{C} \mathrm{g}^{-1}$ de solo (sob vegetação de cerrado e sob pousio após cultura), que foram coerentes com as estimativas calculadas por Feller (1995), em equações de regressão obtidas através de amostras de solo das Antilhas, oeste da África e Brasil (Ponta Grossa e Piracicaba). Aplicando-se aquelas equações (que levam em consideração o teor de argila mais silte e o tipo de uso da terra) obtem-se para as condições desse trabalho os seguintes valores: vegetação natural $=44,85 \mathrm{mg} \mathrm{C} \mathrm{g}^{-1}$ de solo, cultura sem restituição orgânica $=$ $27,37 \mathrm{mg} \mathrm{C} \mathrm{g}^{-1}$ de solo, cultura com restituição orgânica $=34,61 \mathrm{mg} \mathrm{C} \mathrm{g}^{-1}$ de solo. Esses números estimados estão acima dos obtidos neste trabalho. As diferenças entre as estimativas de Lepsch et al. (1994) e de Feller (1995b) podem ser devidas ao fato de que nas equações calculadas pelo último as variáveis consideradas são o teor de argila mais silte e o uso da terra, enquanto que nas equações de Lepsch et al. (1994) leva-se em consideração além disso o regime hídrico e a vegetação nativa do local. Entretanto Feller (1995b), ao incorporar a variável precipitação pluvial às equações, não encontrou aumento do coeficiente de correlação (r), que passou de 0,897 para 0,881 .

Comparando-se a vegetação nativa com a introdução de culturas, o decréscimo ocorrido no teor de carbono do solo não fracionado na camada $0-10 \mathrm{~cm}\left(\mathrm{mg} \mathrm{C} \mathrm{g}{ }^{-1} \mathrm{de}\right.$ solo) foi de $45 \%$ para cultura anual por 20 anos, $26 \%$ para a cobertura do pomar com Arachis prostrata, $22 \%$ para pomar manejado com roçadeira e grade e $12 \%$ para pomar capinado. Para a camada $10-20 \mathrm{~cm}$ as perdas foram de 2,5 a $16 \%$, sendo as maiores para culturas anuais. Lepsch et al. (1994) constataram reduções de 7 a $21 \%$ com a introdução de culturas e Feller et al. (1991) em solos argilosos com cultivo durante dez anos, observaram uma diminuição do teor de matéria orgânica em torno de 30-40 \%.

O estoque orgânico encontrado para o solo sob vegetação de mata na camada de 0-10 cm foi de 27,12 $\mathrm{Mg} \mathrm{ha}^{-1}$, enquanto que para a camada $10-20 \mathrm{~cm}$ foi de 19,0 $\mathrm{Mg} \mathrm{ha}^{-1}$, bem menor do que na camada anterior, concordando com o verificado por Cerri et al. (1991) em uma floresta latifoliada tropical em um latossolo vermelho escuro de Piracicaba. Esses autores constataram que o solo apresentou teores de carbono elevados nos seis $\mathrm{cm}$ superficiais, com um brusco decréscimo a maiores profundidades. Os valores de estoque de $\mathrm{C}$ aqui encontrados foram superiores aos observados por Desjardins et al. 
(1994) que obtiveram 19,2 $\mathrm{Mg} \mathrm{ha}^{-1}$, em um latossolo podzolisado sob floresta tropical na Amazônia, o que pode ser explicado pelo menor teor de argila mais silte daquele solo $(27,4 \%)$.

Comparando-se o estoque de carbono da vegetação de floresta com a introdução de culturas, observa-se que uma redução importante ocorreu apenas na situação de culturas anuais por 20 anos (Tabelas 19 e 21). No pomar, o estoque foi mantido, mesmo na situação de pomar capinado, onde a adição de material orgânico é menor, provavelmente pelo não revolvimento do solo, o que evita as perdas (Karlen \& Cambardella, 1995). Nas situações de cobertura vegetal do pomar chegou a haver um aumento no estoque de carbono, principalmente na camada 10-20 cm (Tabelas 20, 24 e 26). $\mathrm{O}$ aumento de carbono em profundidade com a retirada da mata e a introdução de culturas foi observado também por Cerri et al. (1991) com cana-de-açúcar (Saccharum sp. e por Feigl et al. (1995) com pastagem.

Considerando-se os teores de carbono em cada fração, observa-se que para a fração 200-2.000 $\mu \mathrm{m}$ os valores situaram-se entre 53,3 (no pomar capinado) e 118,0 mg $\mathrm{C} \mathrm{g}^{-1}$ de fração (na floresta) para a profundidade $0-10 \mathrm{~cm}$ e entre 34,7 e $111,0 \mathrm{mg} \mathrm{C} \mathrm{g}^{-1}$ de fração para a profundidade $10-20 \mathrm{~cm}$. Outros trabalhos realizados em situação de clima tropical obtiveram valores mais baixos para esta fração. Freitas et al. (1997)

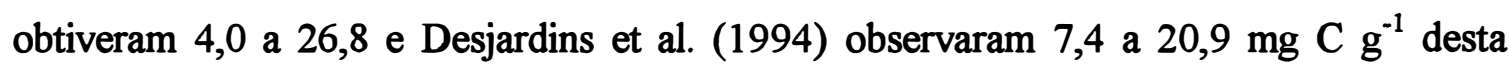
fração. Esta diferença pode ser atribuída à menor proporção de areia encontrada no solo do presente trabalho, em comparação com a situação estudada por aqueles autores, o que contribui para aumentar a proporção da parte orgânica na fração. Corroborando com esta hipótese, os resultados de Kouakoua (1998) em oxisois argilosos do Congo, foram próximos aos obtidos no presente trabalho, variando de 34,7 a 76,2 $\mathrm{mg} \mathrm{C}^{-1}$ de fração.

Os teores de C situaram-se entre 13,1 e $37,4 \mathrm{mg} \mathrm{C} \mathrm{g}^{-1}$ da fração50-200 $\mu \mathrm{m}$ e 8,1 a 27,2 mg C $\mathrm{g}^{-1}$ da fração $20-50 \mu \mathrm{m}$, sendo de maneira geral mais altos em superfície e na vegetação de floresta e mais baixos no pomar capinado. Nestas frações, que granulometricamente abrangem areia fina e muito fina, aplica-se o mesmo raciocínio da fração anterior, pois os valores obtidos foram mais elevados do que os encontrados em 
outros locais com maior teor de areia e foram semelhantes ao obtidos em solos argilosos do Congo (Kouakoua, 1998). Solos com maior teor de areia indicaram 3,2 a 14,9 4 (sob pastagem) e 3,9 a 15,0 $\mathrm{mg} \mathrm{C} \mathrm{g}^{-1}$ da fração 50-200 $\mu \mathrm{m}$ (sob floresta tropical) (Desjardins et al., 94); 1,2 a 9,7 $\mathrm{mg} \mathrm{C} \mathrm{g}^{-1}$ da fração 50-200 $\mu \mathrm{m}$ e 2,4 a $11,4 \mathrm{mg} \mathrm{C} \mathrm{g}^{-1}$ da fração 20-50 $\mu \mathrm{m}$ em solos do cerrado brasileiro (Freitas et al., 1997).

Para a fração 2-20 $\mu \mathrm{m}$, os valores obtidos no presente trabalho foram de 18,3 a $36,2 \mathrm{mg} \mathrm{C} \mathrm{g}^{-1}$ de fração, sendo maiores em superficie e sem diferenças importantes entre as situações de uso da terra. Kouakoua (1998) em solos do Congo obteve valores superiores, entre 21,0 e 84,0 à $0-10 \mathrm{~cm}$ de profundidade, bem como Freitas et al. (1997) que tiveram valores entre 37,9 e $60,9 \mathrm{mg} \mathrm{C}^{-1}$ de fração. Feller (1995b) observou valores de 29,8 a $106,0 \mathrm{mg} \mathrm{C} \mathrm{g}^{-1}$ de fração, sendo que os menores valores foram para cana-deaçúcar e os maiores para mata nativa em Piracicaba (SP), enquanto que em Ponta Grossa (PR) o autor observou 34,4 a 59,0 $\mathrm{mg} \mathrm{C}^{-1}$ de fração.

Para a fração 0-2 $\mu \mathrm{m}$, os valores obtidos neste trabalho foram de 11,0 a 18,0 $\mathrm{mg} \mathrm{g}^{-1}$ de fração, sendo mais altos na vegetação nativa, porém sem diferenças importantes entre as situações de uso da terra. Estes valores são menores que os determinados em outros trabalhos. Kouakoua (1998) encontrou teores de 18,0 a 26,2 no Congo e Freitas et al. (1997) 23,8 a $29,8 \mathrm{mg} \mathrm{C} \mathrm{g}^{-1}$ de fração, em Goiás. Feller (1995b) observou em Piracicaba 15,43 a 45,0 $\mathrm{mg} \mathrm{C} \mathrm{g}^{-1}$ de fração, sendo os menores valores para cana-deaçúcar e os maiores para a vegetação de mata e em Ponta Grossa, esse autor obteve 30,99 a 40,73 $\mathrm{mg} \mathrm{C} \mathrm{g}^{-1}$ de fração.

Considerando-se os teores de carbono em cada fração, observa-se que as maiores reduções no teor de carbono quando se compara a vegetação nativa com as culturas ocorreram na fração 200-2.000 $\mu \mathrm{m}$. Este fato ocorreu também no trabalho de Martins et al. (1990), ao avaliarem a introdução de culturas após a retirada da mata em um latossolo amarelo podzolisado do Pará. Esses autores observaram maiores reduções nas frações 50-200 e 200-2.000 $\mu \mathrm{m}$ e poucas alterações na fração < $50 \mu \mathrm{m}$. Entretanto, no levantamento realizado por Feller et al. (1991) observou-se que para solos argilosos (como o do solo em estudo) as diferenças foram mais acentuadas na fração organo 
argilosa (0-2 $\mu \mathrm{m})$, enquanto que nos solos arenosos as maiores diferenças ocorreram na fração resíduos vegetais $(>20 \mu \mathrm{m})$.

Feller et al. (1991), estudando diversos tipos de solos, observaram que qualquer que fosse a textura, os teores de carbono da fração 20-2.000 $\mu \mathrm{m}$ eram praticamente constantes (de 3 a $5 \mathrm{mg} \mathrm{C} \mathrm{g}^{-1}$ de solo), enquanto que os teores das frações 2-20 $\mu \mathrm{m}$ aumentaram consideravelmente com o teor de argila ( 3 a $8 \mathrm{mg} \mathrm{C} \mathrm{g}^{-1}$ solo), bem como o da fração $0-2 \mu \mathrm{m}$ ( 3 a $17 \mathrm{mg} \mathrm{C} \mathrm{g}^{-1}$ solo). Os resultados do presente trabalho se adequam àquelas estimativas (Figuras 27 e 29), pois para as frações acima de $20 \mu \mathrm{m}$ observaram-se valores de 1,78 a $7,78 \mathrm{mg} \mathrm{C} \mathrm{g}^{-1}$ solo. Para a fração 2-20 $\mu \mathrm{m}$ os valores situaram-se entre 2,47 e $6,47 \mathrm{mg} \mathrm{C} \mathrm{g}^{-1}$ solo e para a fração 0-2 $\mu \mathrm{m}$ foram de 7,48 a 10,37 $\mathrm{mg} \mathrm{C} \mathrm{g}{ }^{-1}$ solo.

A contribuição de cada fração sobre o total de carbono para a profundidade de 0-10 cm, revelou que, para a maioria das situações, a fração 0-2 $\mu \mathrm{m}$ foi responsável por 40,4 a 43,3 \% do total a 0-10 cm (Figura 28) e 45,5 a 50,3 a 10-20 cm (Figura 30). Essa situação foi diferente apenas no caso da vegetação de floresta que apresentou $34,3 \%$ do total de C nesta fração a 0-10 cm. De acordo com Schulten \& Leinweber (1991) nos podzois, luvisois e terras roxas ácidas, a máxima concentração de carbono encontra-se na fração argila enquanto que em chernozens as mais altas concentrações de carbono nas frações de silte fino. As frações 2-20 $\mu \mathrm{m}$ e $20-50 \mu \mathrm{m}$, a 0-10 cm de profundidade, tiveram valores de 23,4 a $28,5 \%$ e 2,1 a $4,0 \%$, respectivamente. Para $10-20 \mathrm{~cm}$, os valores para as frações 2-20 $\mu \mathrm{m}$ e 20-50 $\mu \mathrm{m}$ foram de 14,6 a 26,6 e 2,3 a 6,1, respectivamente. A fração 50-200 $\mu \mathrm{m}$ mostrou diferenças entre os tipos de uso da terra, com valor mais alto sob a vegetação de floresta $(14,6 \%)$ e mais baixo para o pomar manejado com solo nu (7,6 \%), sendo que as demais situações ficaram em posição intermediária (9,0 a 10,8 \%). A fração 200-2.000 $\mu \mathrm{m}$, a 0-10 cm, variou de 2,6\% (na cultura anual) até $8,6 \%$ (na vegetação de floresta).

De maneira geral, estas porcentagens encontradas são próximas das determinadas por Freitas et al. (1997), com exceção da fração 0-2 $\mu \mathrm{m}$, que naquele caso 


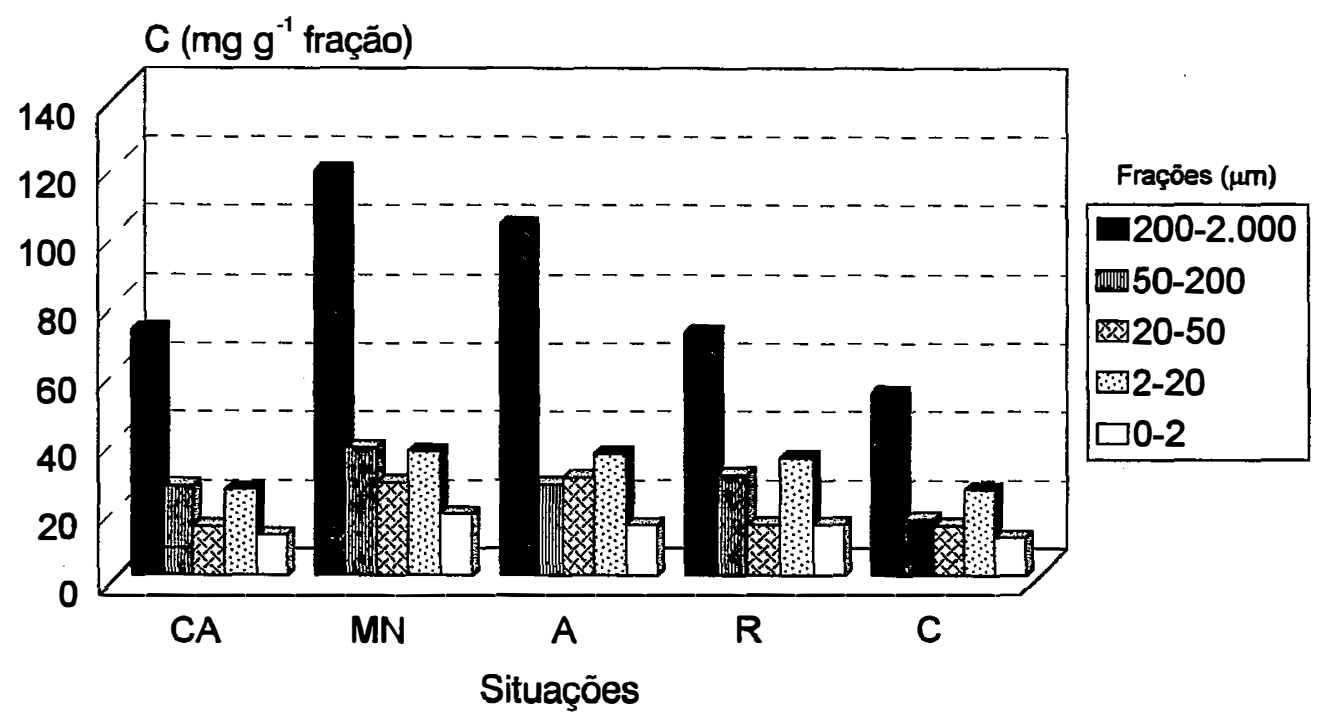

Figura 25. Teor de carbono das frações (em $\mathrm{mg} \mathrm{g}^{-1}$ de fração) na profundidade $0-10 \mathrm{~cm}$, para as situações de culturas anuais (CA), mata nativa (MN), pomar com cobertura com A. prostrata (A), pomar manejado com roçadeira/grade (R), pomar capinado $(\mathrm{C})$.

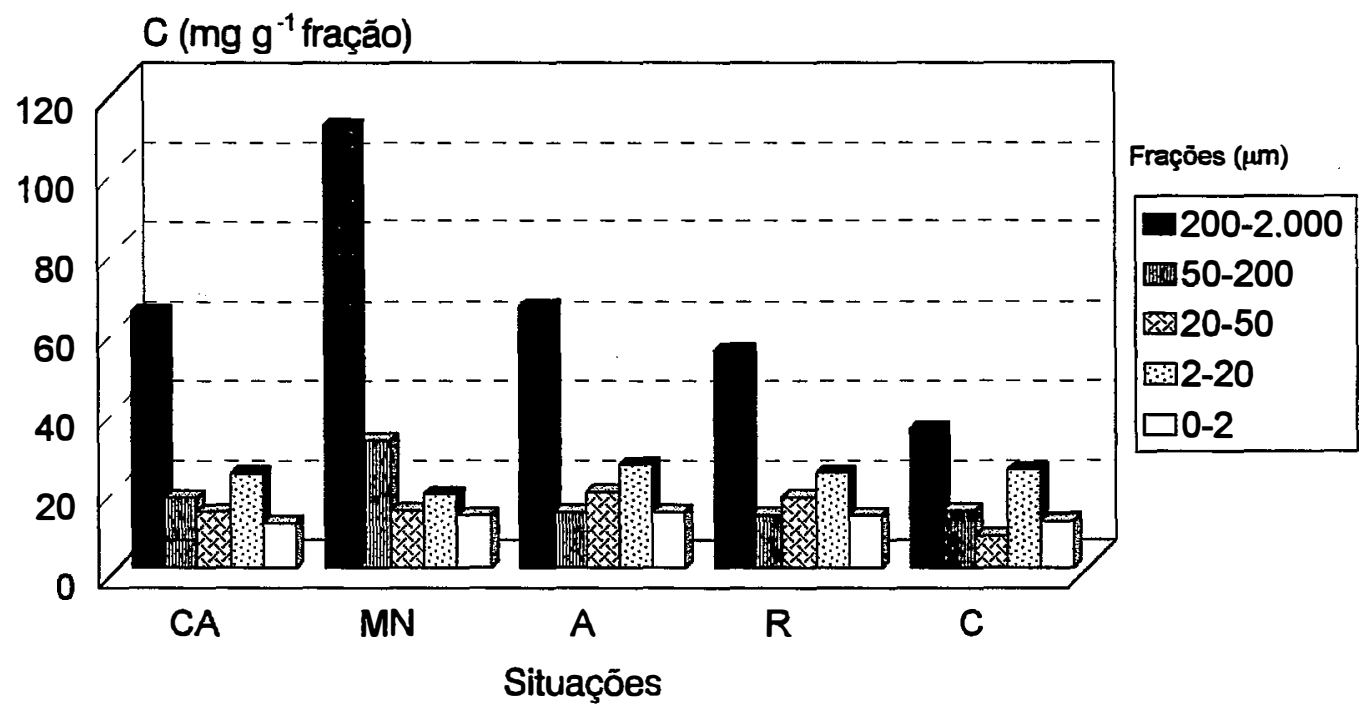

Figura 26. Teor de carbono das frações à profundidade de 10-20 cm, para as situações de culturas anuais (CA), mata nativa $(\mathrm{MN})$, pomar com cobertura com $\mathrm{A}$. prostrata (A), pomar manejado com roçadeira/grade (R), pomar capinado (C). 


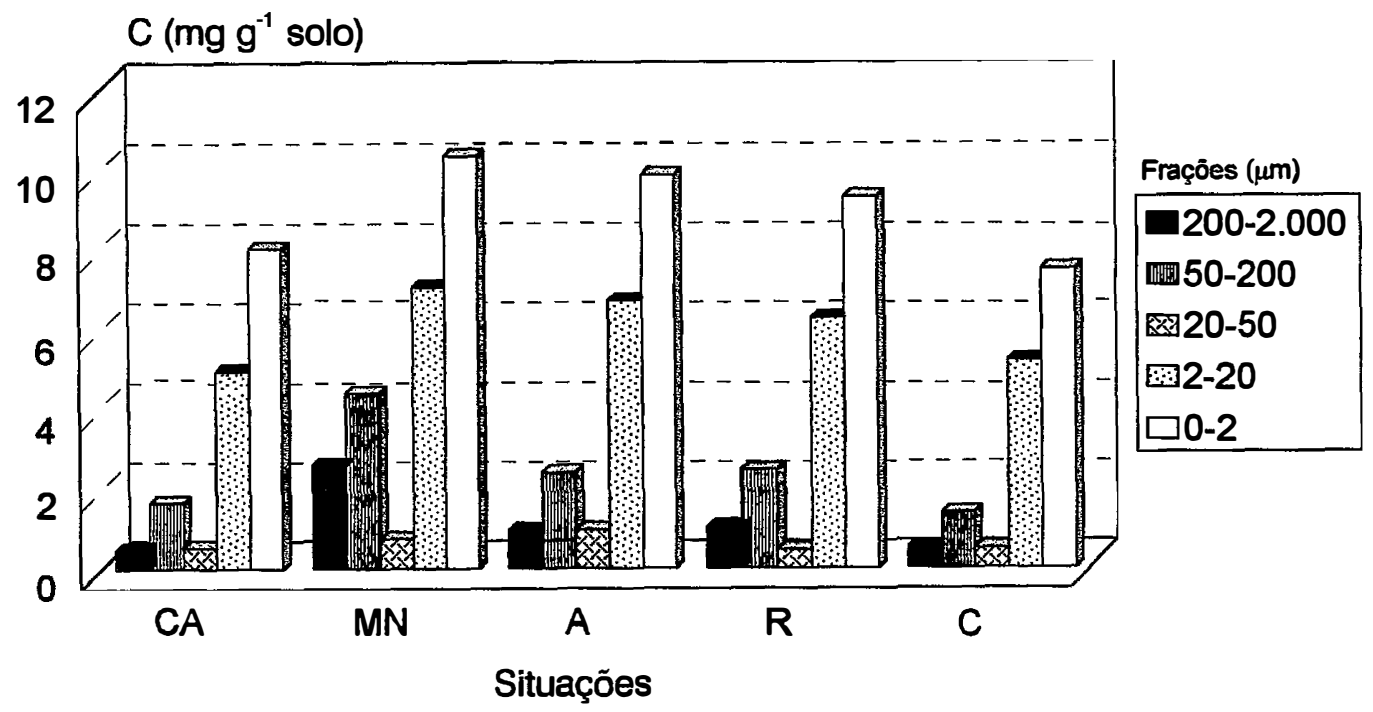

Figura 27. Carbono das frações do solo (em $\mathrm{mg} \mathrm{g}^{-1}$ de solo) à profundidade de 0-10 cm, para as situações de culturas anuais (CA), mata nativa $(\mathrm{MN})$, pomar com cobertura com A. prostrata (A), pomar manejado com roçadeira/grade (R), pomar capinado (C).

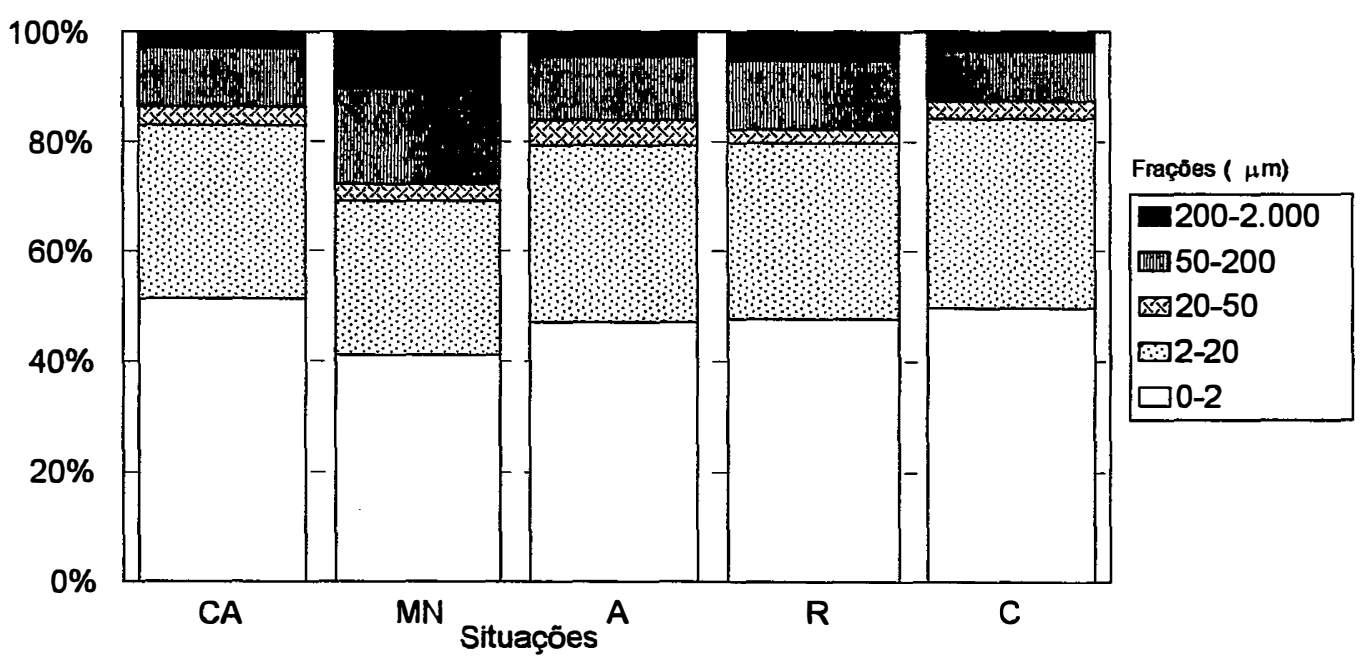

Figura 28. Participação das frações (em \%) no teor total de carbono do solo, à profundidade de $0-10 \mathrm{~cm}$, para as situações de culturas anuais (CA), mata nativa $(M N)$, pomar com cobertura com A. prostrata (A), pomar manejado com roçadeira/grade $(\mathrm{R})$, pomar capinado $(\mathrm{C})$. 


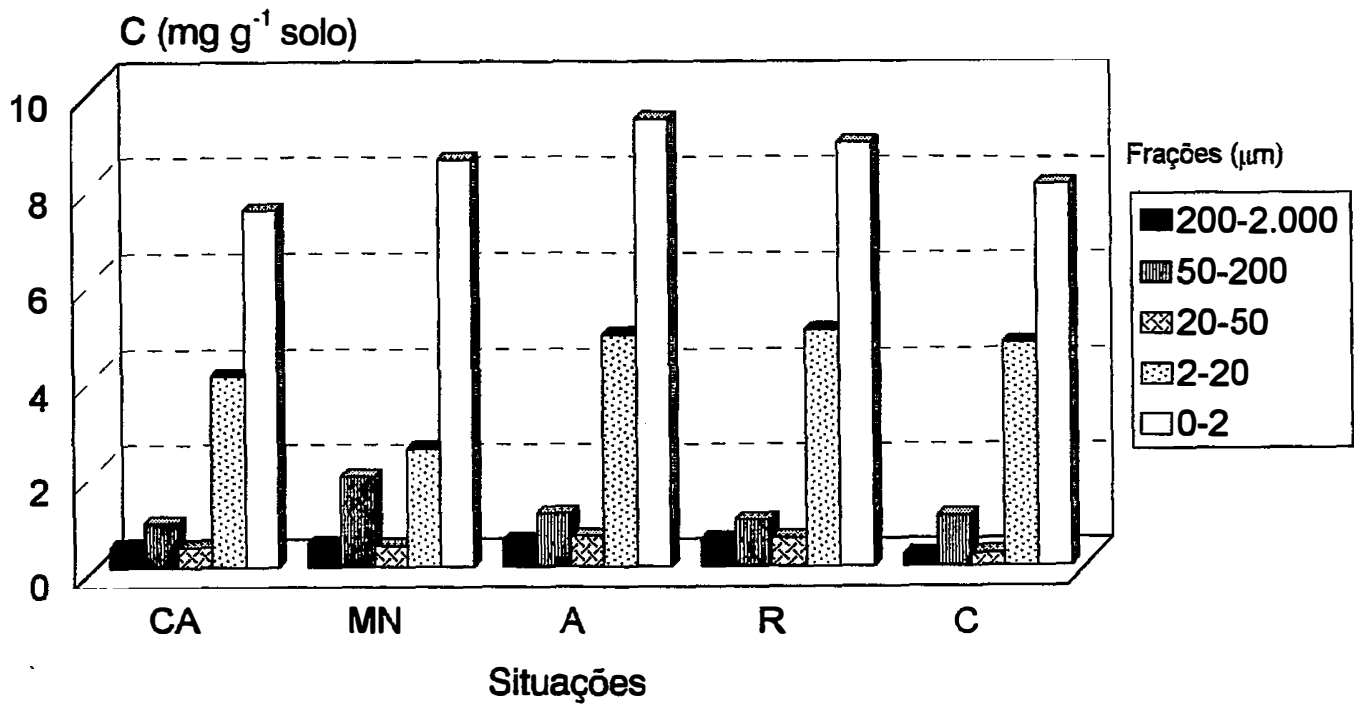

Figura 29. Carbono das frações (em $\mathrm{mg} \mathrm{g}^{-1}$ de solo) à profundidade de $10-20 \mathrm{~cm}$, para as situações de culturas anuais (CA), mata nativa $(M N)$, pomar com cobertura com A. prostrata (A), pomar manejado com roçadeira/grade (R), pomar capinado (C).

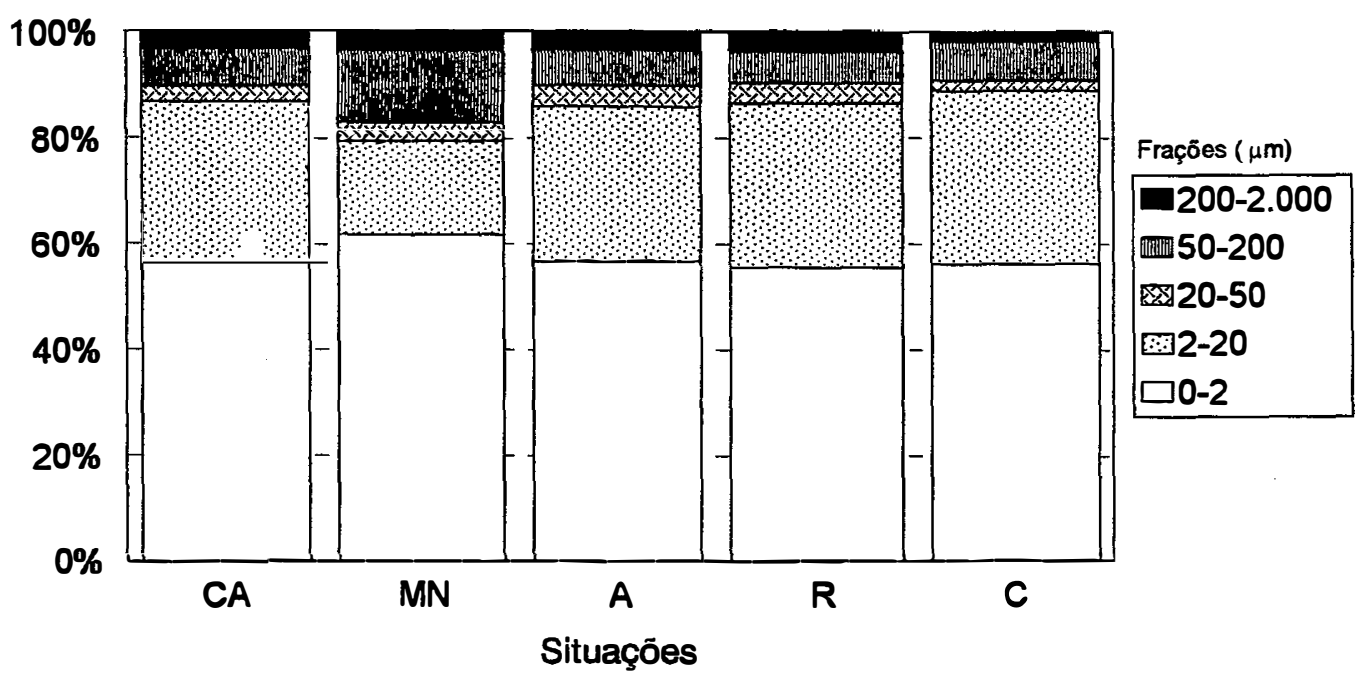

Figura 30. Participação das frações (em \%) no teor total de carbono do solo, à profundidade de $10-20 \mathrm{~cm}$, para as situações de culturas anuais (CA), mata nativa $(\mathrm{MN})$, pomar com cobertura com A. prostrata (A), pomar manejado com roçadeira/grade $(\mathrm{R})$, pomar capinado $(\mathrm{C})$. 


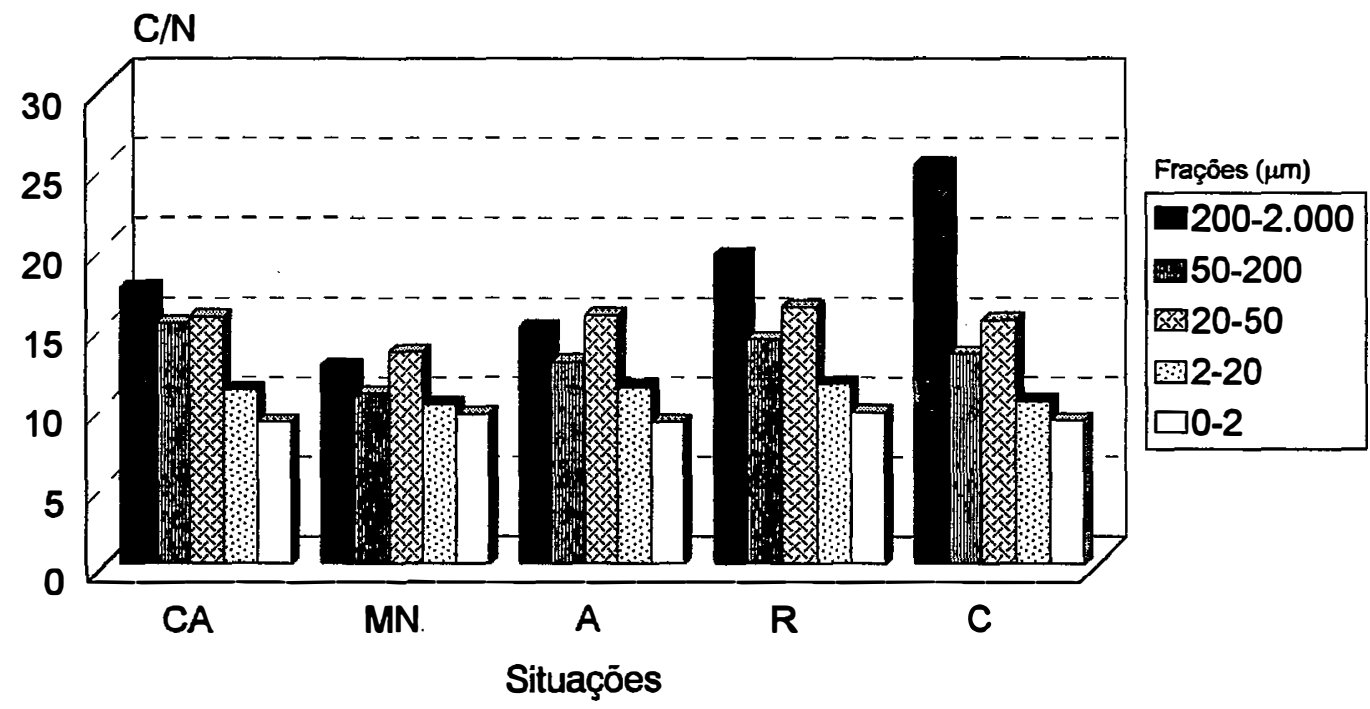

Figura 31. Relação $\mathrm{C} / \mathrm{N}$ das frações do solo $(0-10 \mathrm{~cm})$, para as situações de culturas anuais (CA), mata nativa (MN), pomar com cobertura com A. prostrata (A), pomar manejado com roçadeira/grade (R), pomar capinado (C).

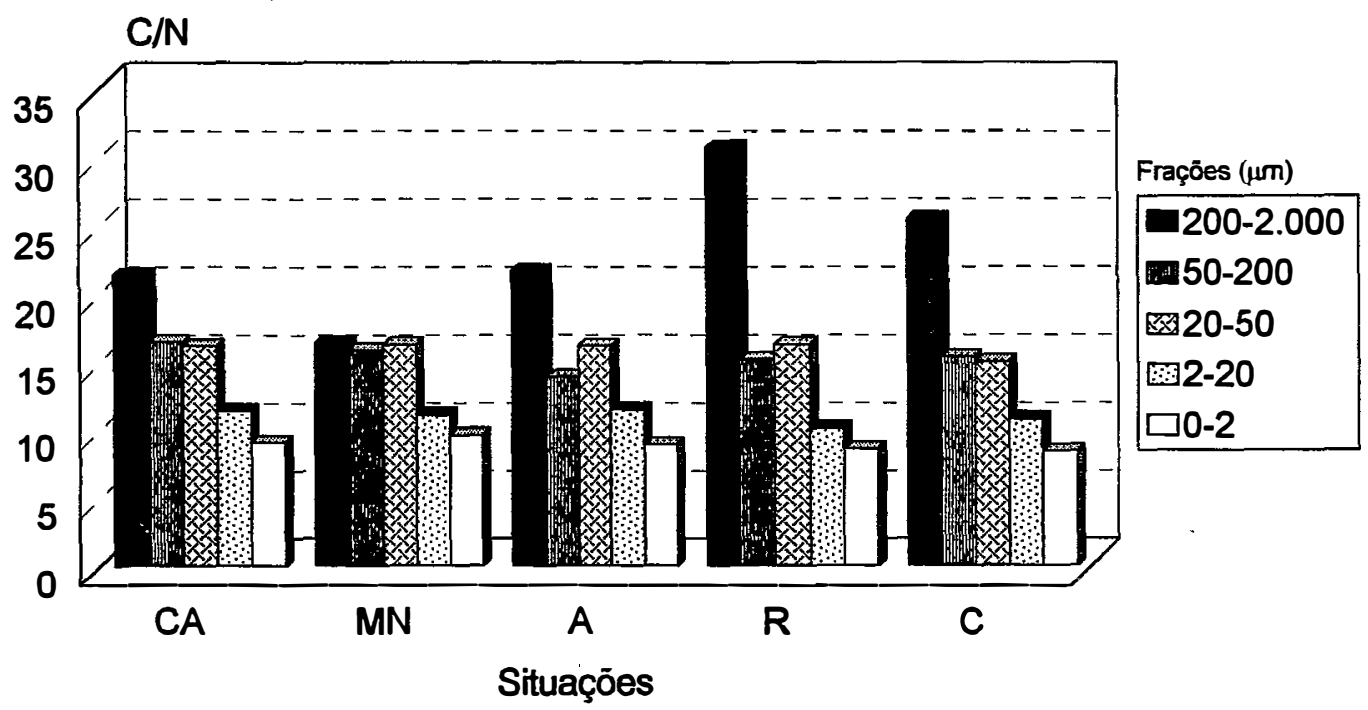

Figura 32. Relação $\mathrm{C} / \mathrm{N}$ das frações do solo $(10-20 \mathrm{~cm})$ para as situações de culturas anuais (CA), mata nativa (MN), pomar com cobertura com A. prostrata (A), pomar manejado com roçadeira/grade (R), pomar capinado (C). 
atingiu a mais alta proporção sob vegetação nativa de cerrado (53,0 \%), enquanto que neste trabalho esta fração atingiu o menor valor na vegetação nativa de mata $(34,3 \%)$. Por outro lado, as diferenças encontradas pelo efeito da introdução do cultivo foram mais acentuadas naquele trabalho. Comparando-se as percentagens aqui encontradas com as observadas por Desjardins et al. (1994) observam-se diferenças principalmente na fração 0-2 $\mu \mathrm{m}$, que foi de $25 \%$ para a floresta e $22 \%$ para pastagem naquele trabalho, enquanto que os resultados aqui apresentados ficaram entre 34,3 a $43,3 \%$ do carbono total. Aquele solo, entretanto, apresentou, para a camada considerada, um teor de argila mais silte de 27,4 \%. Foi demonstrado por Feller (1993) que a importância da fração 0-2 $\mu \mathrm{m}$ aumenta com a proporção de argila mais silte encontrada no solo.

A relação $\mathrm{C} / \mathrm{N}$ do solo não fracionado sob vegetação de mata (Tabelas $21 \mathrm{e}$ 22) foi semelhante à encontrada por Desjardins et al.(1994) em um latossolo podzolisado de textura média da Amazônia, que obtiveram valores de 12,6 à profundidade de 3-10 cm, e por Feigl et al. (1995) também na Amazônia, que obtiveram 13,3, enquanto que neste trabalho o valor para a camada $0-10 \mathrm{~cm}$ foi de 12,1. Freitas et al. (1997) encontraram valores mais altos para a vegetação nativa $(14,8)$, provavelmente em função da presença de gramíneas na vegetação de cerrado.

Quanto à relação C/N das frações, Feller (1993) observou que, de maneira geral, para a fração $200-2.000 \mu \mathrm{m}$ a relação $\mathrm{C} / \mathrm{N}$ foi maior que 15 , para a fração $2-20 \mu \mathrm{m}$ foi de 10-15 e para a fração 0-2 $\mu \mathrm{m}$ foi de menor que 10. Observa-se pelos dados apresentados nas Tabelas 19 a 28 e Figuras 31 e 32, que estes valores gerais se adequam bem aos aqui determinados, com exceção da fração $200-2.000 \mu \mathrm{m}(0-10 \mathrm{~cm})$, que apresentou $\mathrm{C} / \mathrm{N}$ menor que $15(12,4)$. No caso da fração 2-20 $\mu \mathrm{m}$ os valores também estão dentro da faixa (10-15) mas em nenhuma situação ultrapassaram 11,5.

Comparando-se a relação $\mathrm{C} / \mathrm{N}$ (nas profundidades 0-10 e 10-20 cm) do solo do pomar em função do tipo de cobertura, observa-se que a presença da leguminosa Arachis prostrata provocou uma relação C/N de 9,4 e 10,4 para o solo NF (Tabelas 23 e 24) enquanto que as gramíneas do tratamento roçadeira/grade apresentaram resultados mais elevados de 10,8 e 10,8, respectivamente (Tabelas 25 e 26), refletindo o menor teor de $\mathrm{N}$ 
da cobertura vegetal. As diferenças entre as duas coberturas não são maiores provavelmente pela adubação nitrogenada realizada periodicamente para a manutenção do pomar. Com os resultados do fracionamento pode-se perceber que a fração que mais contribuiu para esta diferença na relação $\mathrm{C} / \mathrm{N}$ foi a dos resíduos vegetais (200-2.000 $\mu \mathrm{m}$ principalmente, seguida $50-200 \mu \mathrm{m}$ ), enquanto que as demais apresentaram resultados semelhantes para os dois tipos de cobertura vegetal.

\subsection{Conclusões}

Através dos resultados, para as condições estudadas, pode-se concluir que:

- Os teores de carbono no solo estão de acordo com as estimativas existentes, levando-se em conta o teor de argila mais silte, o clima local e o tipo de uso da terra.

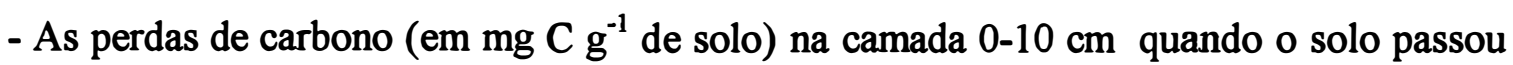
da vegetação nativa para as culturas, foram de 12 a $45 \%$, sendo maiores com culturas anuais por 20 anos. Para a camada $10-20 \mathrm{~cm}$, as perdas foram de 2,5 a $16 \%$, sendo as maiores perdas observadas também para culturas anuais.

- O estoque de carbono na profundidade $0-10 \mathrm{~cm}$ foi redurido em $34 \%$ com culturas anuais em relação à vegetação nativa e foi ligeiramente aumentado no pomar, conduzido ou não com coberturas vegetais.

- O fracionamento granulométrico demonstrou que a maior proporção da matéria orgânica do solo encontrou-se na fração organo-argilosa $(0-2 \mu \mathrm{m})$ com 34 a $43 \%$ do total seguida da fração organo-siltosa $(0-20 \mu \mathrm{m})$ com 23 a $28 \%$ do total.

- Com a introdução das culturas, a fração que mais perdeu matéria orgânica foi a fração 200-2.000 $\mu \mathrm{m}$, nas profundidades de 0-10 e 10-20 cm. 
6 EFEITO DO MANEJO DO SOLO E DA MATÉRIA ORGÂNICA SOLÚVEL EM ÁGUA QUENTE NA ESTABILIDADE DE AGREGADOS DE UM LATOSSOLO ROXO 


\section{EFEITO DO MANEJO DO SOLO E DA MATÉRIA ORGÂNICA SOLÚVEL EM ÁGUA QUENTE NA ESTABILIDADE DE AGREGADOS DE UM LATOSSOLO ROXO}

\subsection{Resumo}

Estudou-se a estabilidade de agregados de um latossolo roxo mantido com vegetação nativa de floresta, culturas anuais por 20 anos e com pomar cítrico manejado durante nove anos com cobertura verde permanente de Arachis prostrata Bong. ex Benth., uso alternado de roçadeira (3-4 vezes no período de chuvas) uma gradagem a disco (no período seco) ou capina manual. A estabilidade de agregados foi determinada em amostras submetidas ou não a água quente, para retirada da matéria orgânica solúvel em água quente. A vegetação de floresta proporcionou maior estabilidade de agregados, seguida da situação de pomar submetido à cobertura permanente ou roçadeira/grade. A extração do carbono solúvel com água quente não provocou diferenças significativas na estabilidade dos agregados.

\subsection{Summary: EFFECT OF ORCHARD SOIL MANAGEMENT AND HOT WATER SOLUBLE ORGANIC MATTER ON AGGREGATE STABILITY OF AN OXISSOL}

It was studied the aggregate stability of an oxisol maintained with native vegetation of forest, annual crops for 20 years and with a citrus orchard mantained during nine years with permanent ground cover of Arachis prostrata Bong. Ex Benth.or 
alternated mowing (3-4 times in the rain period) / tillage (in the dry period) or manual weeding. The aggregate stability was determined in samples submitted or not to hot water to remove hot water soluble organic matter. The forest vegetation provided larger stability, followed by the orchard situations submitted to the permanent covering or mowing/tillage. Extraction of hot-water soluble carbon did not cause significant differences in aggregate stability.

\section{3 Introdução}

A agregação é um dos parâmetros que podem ser utilizados para avaliar a qualidade do solo (Karlen et al., 1997), pois a manutenção da estrutura facilita a aeração, a infiltração de água e reduz a erodibilidade (Angulo et al., 1984). A estabilidade dos agregados é influenciada por diversos fatores, como a textura do solo (Oades, 1993; Feller et al., 1995), o teor de óxidos de ferro a alumínio (Oades \& Waters, 1991), o teor de matéria orgânica (Chaney \& Swift, 1984; Roth et al., 1991), e o tipo de manejo (Carpenedo \& Mielniczuk, 1990; Cambardella \& Elliot, 1993).

No manejo do solo em pomares, o sistema adotado deve apresentar pouca ou nenhuma competição por água e nutrientes com as árvores e manter o solo protegido, principalmente nos períodos de maior ocorrência de chuvas. A estabilidade dos agregados é um dos atributos do solo que podem ser usados para avaliar esta proteção. De maneira geral, os resultados de trabalhos realizados em pomares cítricos, têm demonstrado que a manutenção de vegetação nas entre-linhas da cultura favorecem a agregação. Cintra et al. (1983), na Bahia, observaram $40 \%$ a mais de agregados em pomar permanentemente conduzido com vegetação nativa ceifada quando comparada aos tratamentos em que a vegetação era eliminada através de gradagem, mesmo que apenas na estação seca. $O$ tipo de vegetação usada na cobertura também tem provocado diferenças na agregação. Godefroy \& Bourdeaut (1972) em um solo argilo-areno-limoso da Costa do Marfim observaram que a estabilidade estrutural do solo foi superior nos tratamentos que tiveram leguminosas, em relação à vegetação nativa. Por outro lado, em um experimento na 
Austrália (Greacen \& Perkman, 1953), observou-se que quando o solo foi mantido permanentemente com vegetação natural ceifada, a estabilidade de agregados foi significativamente superior aos demais tratamentos - cultivo no verão mais adubo verde no inverno, cultivo no verão mais adubo verde no inverno mais esterco, ou herbicida.

Alguns trabalhos têm demonstrado existir correlação entre a estabilidade de agregados do solo e o teor de carboidratos solúveis em água quente. Em trabalhos com rotação a cada dois a cinco anos de pastagens e culturas de preparo convencional, em inceptisols da Nova Zelândia, foi demonstrado que a estabilidade de agregados teve um ciclo de aumento durante a fase de pastagem, seguida de um decréscimo com as culturas, apesar de o teor de matéria orgânica permanecer constante nas duas fases (Haynes et al., 1991). Esses autores concluíram, levando em consideração as mudanças a curto prazo na agregação, que estas estariam mais relacionadas a alterações em constituintes orgânicos específicos do que no teor total de matéria orgânica do solo. Observaram também que o teor de carboidratos solúveis em água quente aumentou durante o período de pastagem e diminuiu durante as culturas, com alta correlação entre esta característica do solo e a agregação. Entretanto, os índices de correlação com o teor total de carbono e nitrogênio, carboidratos solúveis em água fria e ácido-hidrolisáveis foram inferiores (Haynes \& Swift, 1990). Resultados semelhantes foram encontrados também por Angers et al. (1993) em um glaysol do Canadá e por Gijsman \& Thomas (1995) em um oxisol da Colômbia. Haynes \& Francis (1993) sugeriram que o aumento na agregação foi devido à produção de carboidratos solúveis em água quente, liberados pela biomassa microbiana presente na rizosfera da pastagem

O presente trabalho teve como objetivo avaliar a estabilidade de agregados em um latossolo roxo submetido a tipos de usos do solo, antes e depois da extração da matéria orgânica solúvel em água quente. 


\section{4 Material e Métodos}

O clima da região de Londrina (PR), segundo a classificação de Köppen, é do tipo Cfa, subtropical úmido, com chuvas em todas as estações, podendo ocorrer seca no período de inverno (Corrêa et al., 1982). O solo estudado (latossolo roxo distrófico) está situado no campus da Universidade Estadual de Londrina pela análise granulométrica apresentou apresentou $691 \mathrm{~g} \mathrm{~kg}^{-1}$ de argila, $216 \mathrm{~g} \mathrm{~kg}^{-1}$ de silte e $93 \mathrm{~g} \mathrm{~kg}^{-1}$ de areia. A análise química do solo, de acordo com a metodologia descrita em Empresa Brasileira de Pesquisa Agropecuária (1979), realizada por ocasião da instalação do pomar revelou os seguintes valores para a camada de $0-15 \mathrm{~cm}: \mathrm{pH}\left(\mathrm{H}_{2} \mathrm{O}\right)=5,38$; matéria orgânica $=29,2 \mathrm{~g}$ $\mathrm{dm}^{-3} ; \mathrm{P}\left(\right.$ Mehlich-1) $=2,04 \mathrm{mg} \mathrm{dm}{ }^{-3} ; \mathrm{K}^{+}=2,3 \mathrm{mmol}_{\mathrm{c}} \mathrm{dm}^{-3} ; \mathrm{Ca}^{+2}=45 \mathrm{mmol}_{\mathrm{c}} \mathrm{dm}^{-3} ; \mathrm{Mg}^{+2}$ $=19 \mathrm{mmol}_{\mathrm{c}} \mathrm{dm}^{-3} ; \mathrm{H}^{+}+\mathrm{Al}^{3+}=70 \mathrm{mmol}_{\mathrm{c}} \mathrm{dm}^{-3}$. Para a camada de $15-30 \mathrm{~cm}$, os resultados foram: $\mathrm{pH}\left(\mathrm{H}_{2} \mathrm{O}\right)=5,02$; matéria orgânica $=17,5 \mathrm{~g} \mathrm{dm}^{-3} ; \mathrm{P}($ Mehlich-1 $)=0,92 \mathrm{mg} \mathrm{dm}^{-3}$; $\mathrm{K}^{+}=1,1 \mathrm{mmol}_{\mathrm{c}} \mathrm{dm}^{-3} ; \mathrm{Ca}^{+2}=33 \mathrm{mmol}_{\mathrm{c}} \mathrm{dm}^{-3} ; \mathrm{Mg}^{+2}=32 \mathrm{mmol}_{\mathrm{c}} \mathrm{dm}^{-3} ; \mathrm{H}^{+}+\mathrm{Al}^{3+}=61$ $\mathrm{mmol}_{\mathrm{c}} \mathrm{dm}^{-3}$.

A área tem sido mantida com um pomar formado por plantas de tangerina var. Poncã (Citrus reticulata Blanco), enxertadas sobre limoeiro var. Cravo (Citrus limonia Osbeck), conduzido durante nove anos em um experimento com cinco tratamentos de manejo de solo, nas entrelinhas das plantas cítricas. Todos os tratamentos receberam calcário dolomítico a cada três a quatro anos e adubação mineral (sulfato de amônio, superfosfato simples e cloreto de potássio) com base nos teores dos elementos no solo e nas produções médias anuais.

Para o presente estudo foram selecionadas as parcelas pertencentes aos seguintes tratamentos: cobertura verde durante todo o ano com a leguminosa perene Arachis prostrata Benth.; uso alternado de uma gradagem a disco (no período seco) e de roçadeira (três a quatro vezes no período de chuvas); capina manual o ano inteiro. Foram retiradas também amostras do mesmo tipo de solo sob mata natural (floresta tropical subperenifólia) e sob cultura anual (aveia no inverno e algodão no verão), de áreas localizadas ao lado do pomar. As amostras foram compostas de seis sub-amostras. 
A estabilidade dos agregados foi determinada de acordo com o método adaptado de Kemper \& Rosenau (1986), com a amostra peneirada a 0-2 mm (Kouakoua et al., 1997). Foram realizadas quatro repetições de cada um dos cinco tratamentos analisados para duas profundidades $(0-10$ e $10-20 \mathrm{~cm})$. As amostras foram submetidas a água fria (30 minutos) ou quente (60 minutos em estufa a $\left.90^{\circ} \mathrm{C}\right)$ e depois peneiradas (malha $200 \mu \mathrm{m}$ ) em um agitador vertical (Kemper \& Rosenau, 1986), com 1,3 cm de amplitude vertical e freqüência 35 ciclos/minuto, durante seis minutos. A fração que passou pela peneira teve o teor de argila + silte fino determinado através da pipeta de Robinson. A fração restante na peneira, que representa a fração $\mathrm{AE}+\mathrm{AG}$ (agregados estáveis mais areia grossa) teve o peso determinado e foi dispersa com $\mathrm{NaOH} 0,05 \mathrm{Me}$ peneirada novamente para obtenção da fração AG (que não passaram pela peneira depois da desagregação) e AE. A taxa de agregados estáveis (AE) em água foi calculada pela expressão ((AE+AG)-AG).

A dosagem do carbono solubilizado pela água quente foi realizada no filtrado obtido por centrifugação (4.000 r.p.m. durante 30 minutos). $O$ teor de carbono solúvel foi avaliado por um analisador Shimadzu TOC 5000. O teor de carbono total foi determinado por combustão via seca em um analisador CHN 600, Leco Corporation. Todas as determinações foram realizadas no ORSTOM, Montpellier, França.

Os resultados foram analisados em delineamento inteiramente ao acaso, com quatro repetições. Os tratamentos foram dispostos num esquema fatorial, sendo os fatores o uso da terra e a temperatura da água usada na avaliação da agregação.

\subsection{Resultados e Discussão}

Na Tabela 29 são apresentados os dados de carbono total do solo e de carbono solúvel em água quente ( $\mathrm{mg} \mathrm{C}^{-1}$ de solo).

A estabilidade dos agregados, em $\mathrm{g} \mathrm{AE} \mathrm{kg}^{-1}$ solo, determinada antes e depois do tratamento com água quente, é apresentada na Tabela 30 (profundidade 0-10 $\mathrm{cm}$ ) e Tabela 31 (profundidade 10-20 cm). Observa-se, comparando os tratamentos de manejo 
Tabela 29. Teor de carbono total do solo e solúvel em água quente ( $\mathrm{mg} \mathrm{g}^{-1}$ de solo) para as situações estudadas, nas profundidades de 0-10 e 10-20 cm.

\begin{tabular}{cccccc}
\hline Tratamento & \multicolumn{2}{c}{$0-10 \mathrm{~cm}$} & & \multicolumn{2}{c}{$10-20 \mathrm{~cm}$} \\
\cline { 2 - 3 } \cline { 5 - 6 } & $\mathrm{Ct}$ & $\mathrm{Cs}$ & & $\mathrm{Ct}$ & $\mathrm{Cs}$ \\
\hline Cultura anual & 17,70 & 0,28 & & 16,80 & 0,12 \\
Mata & 31,90 & 0,85 & & 20,00 & 0,20 \\
Pomar - A. prostrata & 23,60 & 0,45 & & 19,10 & 0,18 \\
Pomar - Roçad./Gr. & 24,90 & 0,32 & & 19,50 & 0,17 \\
Pomar - Capina & 26,30 & 0,25 & & 21,40 & 0,12 \\
\hline
\end{tabular}

de solo, que o solo submetido à vegetação de mata nativa foi o que apresentou a maior estabilidade, significativamente superior a todos os demais. As menores taxas de agregados estáveis foram observadas no tratamento de culturas anuais por 20 anos e no pomar capinado. Entre os tratamentos do pomar, houve um aumento significativo da porcentagem de agregados estáveis quando o pomar foi submetido a presença de cobertura vegetal (tratamentos $A$. prostrata e Roçadeira/grade) comparando-se com o pomar mantido no limpo (tratamento Capina). Resultados de porosidade (item 4 desta tese) demonstraram que no tratamento capina houve uma redução da porosidade do solo, provavelmente provocado pelo impacto das gotas, causando desagregação das partículas e selamento superficial, o que é confirmado pelos resultados de estabilidade de agregados.

Comparando-se os dois tratamentos de cobertura vegetal do pomar, observa-se que o teor de matéria orgânica foi semelhante nos dois, bem como a estabilidade de agregados, indicando que estes dois sistemas de manejo contribuíram de forma semelhante para a manutenção da agregação do solo, mesmo considerando que o tratamento Roçadeira/grade recebe uma gradagem ao ano. Este fator é provavelmente neutralizado pela vegetação nativa, em que há um predomínio de gramíneas. Para Tisdall 
Tabela 30. Taxa de agregados estáveis em solo submetido às condições de cultura anual, mata, e de pomar manejado com Arachis prostata, roçadeira/grade ou capina, na profundidade de $0-10 \mathrm{~cm}$, desagregados através de água fria ou quente. (médias de quatro repetições).

\begin{tabular}{ccc}
\hline Tratamento & \multicolumn{2}{c}{ Agregados estáveis $\left(\mathrm{g} \mathrm{kg}^{-1}\right)$} \\
\cline { 2 - 3 } & Água fria & Água quente \\
\hline Cultura anual & $550,6 \mathrm{c} \mathrm{A}^{*}$ & $548,2 \mathrm{~d} \mathrm{~A}$ \\
Mata & $751,9 \mathrm{a} \mathrm{A}$ & $792,5 \mathrm{a} \mathrm{A}$ \\
Pomar - A. prostrata & $638,6 \mathrm{~b} \mathrm{~A}$ & $663,3 \mathrm{~b} \mathrm{~A}$ \\
Pomar - Roçad./Gr. & $626,0 \mathrm{~b} \mathrm{~A}$ & $623,3 \mathrm{bc} \mathrm{A}$ \\
Pomar - Capina & $552,0 \mathrm{c} \mathrm{A}$ & $567,5 \mathrm{~cd} \mathrm{~A}$ \\
\hline D.M.S. (tratam.) & 72,25 & \\
D.M.S. (temp. água) & 50,93 & \\
C.V. (\%) & 5,582 & \\
\hline
\end{tabular}

* Médias seguidas da mesma letra, minúscula na vertical e maiúscula na horizontal, não diferem entre si pelo teste de Tukey ao nível de $5 \%$ de probabilidade.

\& Oades (1982) e Fahad et al. (1982), as raizes das gramíneas são decompostas mais lentamente e portanto atuam como importantes agentes estabilizadores dos macroagregados, contribuindo para a melhoria da estrutura. Na gramínea estudada por Tisdal \& Oades (1979), os autores atribuíram esta melhoria à maior população de fungos micorrízicos. Greacen \& Perkman (1953), trabalhando com leguminosa, vegetação natural ceifada e solo limpo através de herbicida (querosene), tiveram redução do estado de agregação do solo com a leguminosa em pomar cítrico na Austrália. Este resultado deve-se provavelmente ao fato de ter sido o adubo verde anual e portanto semeado anualmente após um cultivo com arado, pois no mesmo trabalho, a vegetação natural ceifada aumentou a porcentagem de agregação para 20,22 \% quando comparada com $7,20 \%$ no tratamento de herbicida e $1,93 \%$ no tratamento de adubo verde, embora o teor de carbono não tivesse diferença significativa, depois de cinco anos de experimento. 
Tabela 31. Taxa de agregados estáveis em solo submetido às condições de cultura anual, mata, e de pomar manejado com Arachis prostrata, roçadeira/grade ou capina, na profundidade de 10-20 cm, desagregados através de água fria ou quente. (médias de quatro repetições).

\begin{tabular}{ccc}
\hline Tratamento & \multicolumn{2}{c}{ Agregados estáveis $\left(\mathrm{g} \mathrm{kg}^{-1}\right)$} \\
\cline { 2 - 3 } & Água fria & Água quente \\
\hline Cultura anual & $548,3 \mathrm{c} \mathrm{A}^{*}$ & $557,6 \mathrm{bc} \mathrm{A}$ \\
Mata & $688,5 \mathrm{a} \mathrm{A}$ & $726,1 \mathrm{a} \mathrm{A}$ \\
Pomar - A. prostrata & $568,5 \mathrm{bc} \mathrm{A}$ & $591,7 \mathrm{~b} \mathrm{~A}$ \\
Pomar - Roçad./Gr. & $629,0 \mathrm{ab} \mathrm{A}$ & $585,5 \mathrm{~b} \mathrm{~A}$ \\
Pomar - Capina & $545,7 \mathrm{c} \mathrm{A}$ & $488,0 \mathrm{c} \mathrm{A}$ \\
\hline D.M.S. (tratam.) & 74,74 & \\
D.M.S. (temp. água) & 52,68 & \\
C.V. (\%) & 6,149 & \\
\hline
\end{tabular}

* Médias seguidas da mesma letra, minúscula na vertical e maiúscula na horizontal, não diferem entre si pelo teste de Tukey ao nível de $5 \%$ de probabilidade.

Comparando-se os resultados da taxa de agregados estáveis obtida com e sem a extração de carbono solúvel em água quente (Tabelas 30 e 31 e Figuras 33 e 34), notase que esta propriedade não foi influenciada pela extração, apresentando resultados semelhantes nos dois casos. De acordo com Oades \& Water (1991) a matéria orgânica tem um papel dominante na agregação dos alfissols e molissols, mas nos oxissols, apesar de contribuir para a agregação, o papel dominante é exercido pelos óxidos de ferro e alumínio. Da mesma forma, Feller et al. (1995) observaram diferenças entre tipos de solo, principalmente para os microagregados $(0-5 \mu \mathrm{m})$ que nos oxisols apresentaram alta estabilidade para qualquer nível de matéria orgânica, enquanto que nos vertisols estes agregados apresentaram a estabilidade variável com a matéria orgânica do solo. 


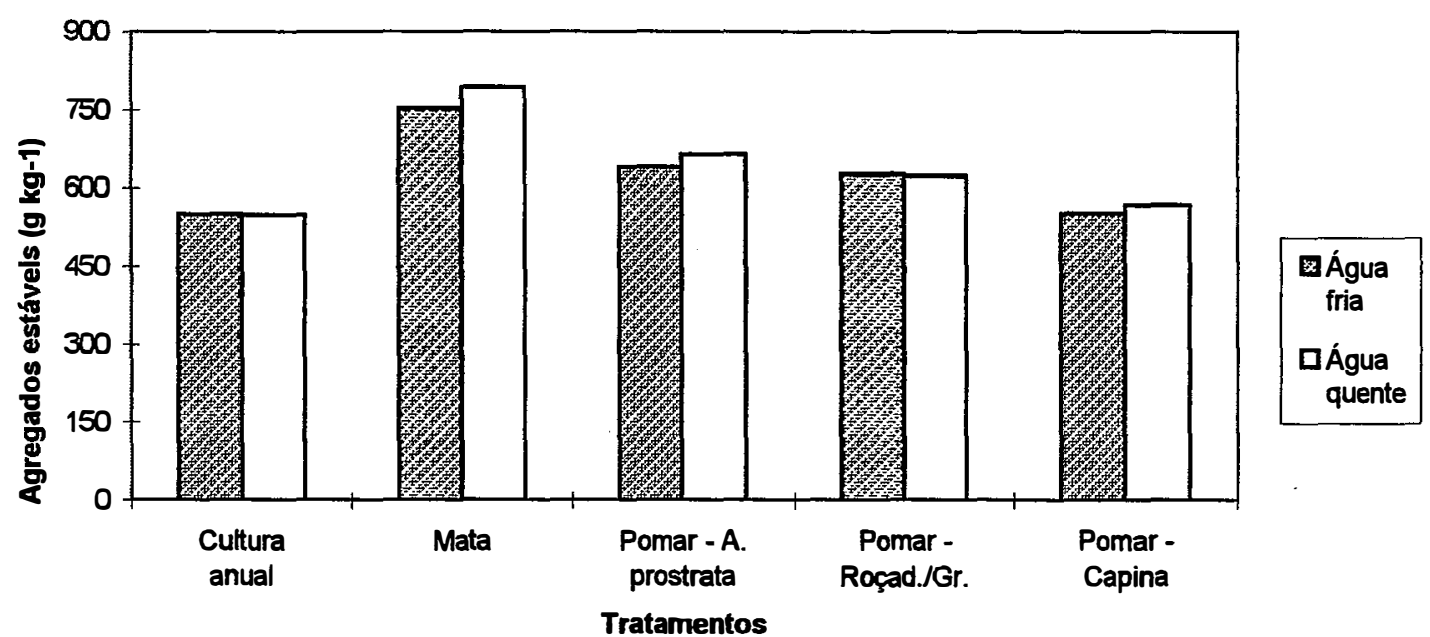

Figura 33. Taxa de agregados estáveis $\left(\mathrm{g} \mathrm{kg}^{-1}\right)$ submetidos às situações de cultura anual, mata, pomar com cobertura de A. prostrata, pomar com roçadeira/grade e pomar capinado, na profundidade de $0-10 \mathrm{~cm}$.

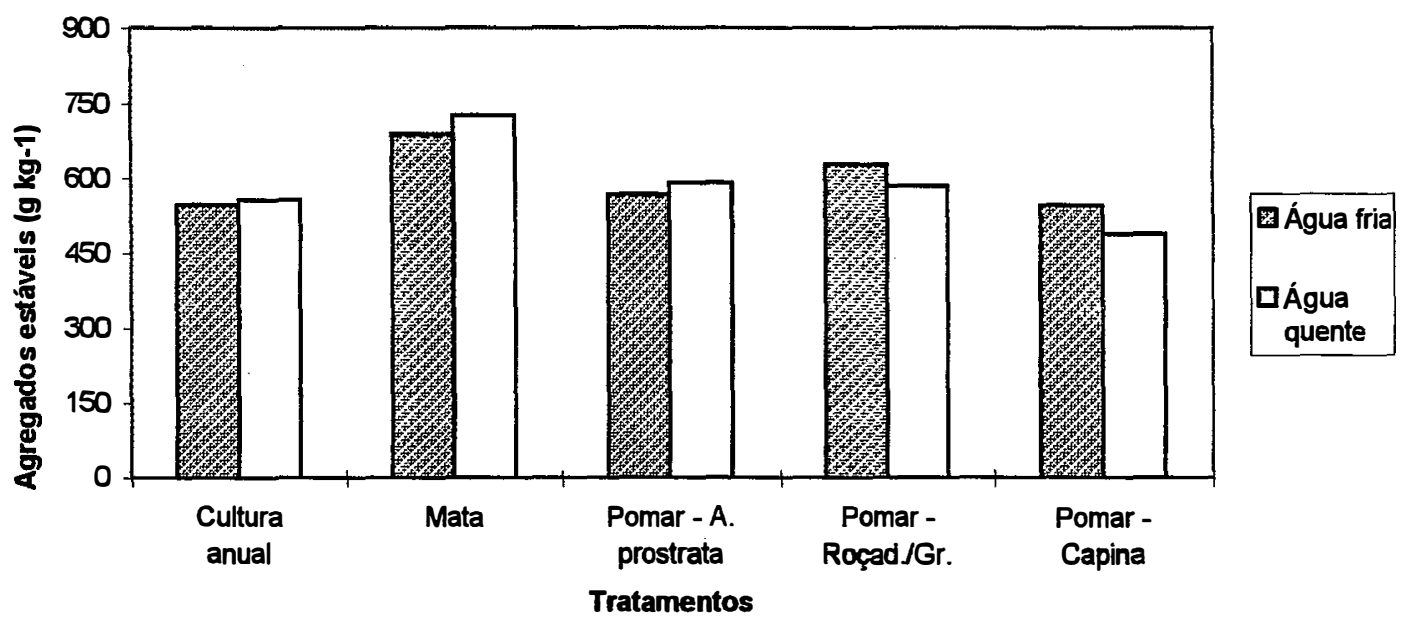

Figura 34. Taxa de agregados estáveis $\left(\mathrm{g} \mathrm{kg}^{-1}\right)$ submetidos às situações de cultura anual, mata, pomar com cobertura de $A$. prostrata, pomar com roçadeira/grade e pomar capinado, na profundidade de $10-20 \mathrm{~cm}$. 
Kouakoua et al. (1997), ao realizarem a determinação da taxa de agregados estáveis antes e depois da extração com de água quente, em oxisolos do Congo, também não encontraram diferenças significativas, apesar de existir alta correlação entre a estabilidade e o teor de carbono solúvel em água quente, indicando que algum outro fator deve estar envolvido na estabilidade dos agregados. Segundo os autores, a medição do efeito direto do teor das frações orgânicas na agregação é importante para testar as conclusões que são obtidas a partir de dados estatísticos.

\section{6 Conclusões}

Os resultados do presente trabalho permitiram concluir que:

- A estabilidade de agregados foi significativamente reduzida quando o solo passou da vegetação de mata nativa para culturas. Esta redução foi mais acentuada para o solo com culturas anuais e com pomar capinado e menor para o solo com cobertura vegetal. Estas mudanças ocorreram tanto na profundidade $0-10 \mathrm{~cm}$ como $10-20 \mathrm{~cm}$.

- A estabilidade de agregados não foi alterado pelo tratamento para a extração da matéria orgânica solúvel em água quente. 
7 CONCLUSÕES 


\section{CONCLUSÕES}

Com a análise dos resultados e nas condições em que o trabalho foi desenvolvido, pode-se concluir que

- Os tratamentos de manejo de solo utilizados neste experimento não tiveram influência significativa na produção, qualidade dos frutos, teores de nutrientes no solo e sobre o estado nutricional das plantas de tangerina 'Poncã'. Em números absolutos ocorreu maior produção no tratamento de gradagem na época seca e roçadeira na época de chuvas.

- A quantidade total de raízes das plantas cítricas não foi afetada pelos sistemas de manejo de solo avaliados, mas a distribuição do sistema radicular dos citros apresentou diferenças significativas entre os tratamentos: a presença de vegetação nas entrelinhas limitou as raízes às regiões do perfil onde não havia raízes das plantas de cobertura. $\mathrm{O}$ tratamento com a cobertura de Arachis prostrata aumentou significativamente o aprofundamento do sistema radicular dos citros

- O estudo realizado através do perfil cultural possibilitou observar modificações das condições físicas do solo que não foram detectadas através do estudo realizado em amostragens por profundidade. As coberturas de leguminosas foram os tratamentos que possibilitaram maior porosidade e menor densidade do solo, avaliadas a partir de estruturas observadas no perfil cultural. $O$ uso de uma gradagem mais roçadeira três a quatro vezes ao ano provocou uma camada compactada na profundidade de $5-15 \mathrm{~cm}$. $O$ solo mantido descoberto causou o aparecimento de uma camada superficial com menor porosidade. Entretanto, estas condições não afetaram o desenvolvimento das raízes.

- O teor de matéria orgânica do solo na camada de 0-20 cm foi aumentado nos tratamentos de cobertura vegetal. As perdas de carbono na camada 0-10 cm quando o 
solo passou da vegetação nativa para as culturas, foram de 12 a $45 \%$, sendo maiores com culturas anuais por 20 anos. Para a camada $10-20 \mathrm{~cm}$, as perdas foram de 2,5 a 16 $\%$, sendo as maiores perdas observadas também para culturas anuais. $O$ estoque de carbono foi reduzido em $34 \%$ com culturas anuais em relação à vegetação nativa e foi ligeiramente aumentado nas situações de pomar, na profundidade $0-10 \mathrm{~cm}$.

- O fracionamento granulométrico da matéria orgânica do solo demonstrou que a maior proporção da matéria orgânica do solo encontrou-se na fração organo-argilosa (0-2 $\mu \mathrm{m})$ com 34 a $43 \%$ do total, seguida da fração organo-siltosa $(0-20 \mu \mathrm{m})$ com 23 a $28 \%$ do total. Com a introdução das culturas, a fração que mais perdeu matéria orgânica foi a fração 200-2.000 $\mu \mathrm{m}$, nas profundidades de 0-10 e 10-20 cm.

- A estabilidade de agregados foi significativamente reduzida quando o solo passou da vegetação de mata nativa para culturas. Esta redução foi mais acentuada para o solo com culturas anuais e com pomar capinado e menor para o solo com cobertura vegetal. Estas mudanças ocorreram tanto na profundidade $0-10 \mathrm{~cm}$ como $10-20 \mathrm{~cm}$. A estabilidade de agregados não foi alterada pelo tratamento para a extração da matéria orgânica solúvel em água quente. 
ANEXO A 
Tabela 32. Análise da variância dos resultados de produção, em número e quilogramas de frutos, para os anos de 1992 a 1995 e para a média desse período.

\begin{tabular}{|c|c|c|}
\hline & \multicolumn{2}{|c|}{ Causa da variação } \\
\hline & Tratamento & Resíduo \\
\hline$\overline{\text { G.L. }}$ & 4 & 15 \\
\hline \multicolumn{3}{|l|}{ Q.M. } \\
\hline Produção (número) 1992 & $83.322,3312500$ n.s. ${ }^{*}$ & $41.890,4250000$ \\
\hline Produção (número) 1993 & $12.236,6687500$ n.s. & $29.267,5250000$ \\
\hline Produção (número) 1994 & $14.602,0812500$ n.s. & $66.457,5208333$ \\
\hline Produção (número) 1995 & $39.317,2187500$ n.s. & $77.433,0041667$ \\
\hline Produção (número) 1992-5 & $16.161,2792969$ n.s. & $19.239,1432292$ \\
\hline Produção (kg) 1992 & $3.158,2156749$ n.s. & $1.326,5529146$ \\
\hline Produção (kg) 1993 & 436,4629581 n.s. & $1.006,5577625$ \\
\hline Produção (kg) 1994 & 457,5105522 n.s. & $2.628,4761358$ \\
\hline Produção (kg) 1995 & $1.112,5415329$ n.s. & $3.070,8446838$ \\
\hline Produção (kg) 1992-5 & 538,3402016 n.s. & 719,6687666 \\
\hline
\end{tabular}

* n.s. = não significativo 
Tabela 33. Análise da variância dos resultados de peso médio do fruto, percentagem de suco, sólidos solúveis, acidez total e ratio (relação sólidos solúveis/ acidez) para os anos de 1992 a 1995.

\begin{tabular}{lcc}
\hline & \multicolumn{2}{c}{ Causa da variação } \\
\hline G.L. & Tratamento & Resíduo \\
\hline \multicolumn{1}{c}{ Q.M. } & 4 & 15 \\
Peso fruto 1992 & 38,7539513 n.s.* & 353,2824136 \\
Peso fruto 1993 & 134,4812500 n.s. & 414,0250000 \\
Peso fruto 1994 & 170,4250000 n.s. & 988,5166667 \\
Peso fruto 1995 & 249,8000000 n.s. & 659,6291667 \\
\hline \% suco 1992 & 10,7514923 n.s. & 10,4050679 \\
\% suco 1993 & 5,7096894 n.s. & 2,8600821 \\
\% suco 1994 & 6,4848766 n.s. & 5,6785657 \\
\% suco 1995 & 13,5503447 n.s. & 9,5233735 \\
\hline sólidos solúveis 1992 & 0,0892589 n.s. & 0,0954975 \\
sólidos solúveis 1993 & 0,7180143 n.s. & 0,5611628 \\
sólidos solúveis 1995 & 0,1750402 n.s. & 0,5973227 \\
\hline acidez 1992 & 0,0029050 n.s. & 0,0047517 \\
acidez 1993 & 0,0012750 n.s. & 0,0015133 \\
acidez 1995 & 0,0108875 n.s. & 0,0029100 \\
\hline ratio 1992 & 1,8655172 n.s. & 4,0069717 \\
ratio 1993 & 7,8311414 n.s. & 5,5990974 \\
ratio 1995 & 31,1556370 n.s. & 11,3510341 \\
\hline
\end{tabular}

n.s. = não significativo 
Tabela 34. Análise da variância dos dados de teores de nutrientes nas folhas de tangerina 'Poncã' (N, P, K, Ca, Mg, S, B, Cu, Fe, Mn e Zn).

\begin{tabular}{ccc}
\hline & \multicolumn{2}{c}{ Causa da variação } \\
\hline G.L. & Tratamento & Resíduo \\
\hline Q.M. & 4 & 15 \\
N folha & 2,1218327 n.s. & 9,7969782 \\
P folha & 0,0129999 n.s. & 0,0198334 \\
K folha & 2,7262458 n.s. & 3,3675005 \\
Ca folha & 82,2692300 n.s. & 46,8556800 \\
Mg folha & 0,1217500 n.s. & 0,4796700 \\
S folha & $0,7392500 *$ & 0,1350000 \\
B folha & 192,8750000 n.s. & 150,9000000 \\
Cu folha & 1,6250000 n.s. & 2,8833333 \\
Fe folha & $1.215,1750000$ n.s. & $1.405,3500000$ \\
Mn folha & $3.366,0750000$ n.s. & $5.032,8166667$ \\
Zn folha & 2,8250000 n.s. & 3,1500000 \\
\hline
\end{tabular}

${ }^{1}$ : n.s. = não significativo; $*$ = significativo a $5 \% ; * *=$ significativo a $1 \%$. 
Tabela 35. Análise da variância dos resultados da análise química do solo para as profundidades 0-20 e 20-40 cm, na entrelinha do pomar (matéria orgânica, $\mathrm{pH}, \mathrm{P}, \mathrm{K}, \mathrm{Ca}, \mathrm{Mg}, \mathrm{H}+\mathrm{Al}$, soma de bases, $\mathrm{T}$ e V\%).

\begin{tabular}{|c|c|c|}
\hline & \multicolumn{2}{|c|}{ Causa da variação } \\
\hline & Tratamento & Resíduo \\
\hline G.L. & 4 & 15 \\
\hline \multicolumn{3}{|l|}{ Q.M. } \\
\hline M.O., $0-20 \mathrm{~cm}$ & $40,5457000 * *$ & 5,5524500 \\
\hline $\mathrm{pH}, 0-20 \mathrm{~cm}$ & 0,1767541 n.s. & 0,1369573 \\
\hline$P, 0-20 \mathrm{~cm}$ & 12,9620058 n.s. & 6,3731649 \\
\hline $\mathrm{K}, 0-20 \mathrm{~cm}$ & 2,5637500 n.s. & 1,4575000 \\
\hline $\mathrm{Ca}, 0-20 \mathrm{~cm}$ & 237,1167800 n.s. & 157,5673900 \\
\hline $\mathrm{Mg}, 0-20 \mathrm{~cm}$ & 23,9482200 n.s. & 30,4811100 \\
\hline $\mathrm{H}+\mathrm{Al}, 0-20 \mathrm{~cm}$ & 67,1355300 n.s. & 66,3485000 \\
\hline $\mathrm{SB}, 0-20 \mathrm{~cm}$ & 364,5740900 n.s. & 296,4335800 \\
\hline $\mathrm{T}, 0-20 \mathrm{~cm}$ & 241,4233500 n.s. & 322,8838000 \\
\hline $\mathrm{V}, 0-20 \mathrm{~cm}$ & 86,8410646 n.s. & 53,8569324 \\
\hline M.O., $20-40 \mathrm{~cm}$ & 14,2062500 n.s. & 7,0781700 \\
\hline $\mathrm{pH}, 20-40 \mathrm{~cm}$ & 0,0854934 n.s. & 0,1092934 \\
\hline$P, 20-40 \mathrm{~cm}$ & 5,6517556 n.s. & 2,5868320 \\
\hline $\mathrm{K}, 20-40 \mathrm{~cm}$ & 1,3645000 n.s. & 1,0086700 \\
\hline $\mathrm{Ca}, 20-40 \mathrm{~cm}$ & 108,1861100 n.s. & 118,9355400 \\
\hline $\mathrm{Mg}, 20-40 \mathrm{~cm}$ & $113,5570300 * *$ & 14,5026600 \\
\hline $\mathrm{H}+\mathrm{Al}, 20-40 \mathrm{~cm}$ & 153,9489600 n.s. & 145,7169200 \\
\hline $\mathrm{SB}, 20-40 \mathrm{~cm}$ & 431,0754200 n.s. & 171,2165500 \\
\hline $\mathrm{T}, 20-40 \mathrm{~cm}$ & 522,3009300 n.s. & 201,5330900 \\
\hline $\mathrm{V}, 20-40 \mathrm{~cm}$ & 170,9644303 n.s. & 155,9186884 \\
\hline
\end{tabular}

${ }^{1}$ : n.s. = não significativo; $*$ significativo a $5 \% ; * *$ significativo a $1 \%$ 
Tabela 36. Análise da variância dos dados da análise quimica do solo para as profundidades 0-20 e 20-40 cm, na projeção da copa (matéria orgânica, $\mathrm{pH}$, $\mathrm{P}, \mathrm{K}, \mathrm{Ca}, \mathrm{Mg}, \mathrm{H}+\mathrm{Al}$, soma de bases, $\mathrm{T}$ e V\%).

\begin{tabular}{|c|c|c|}
\hline & \multicolumn{2}{|c|}{ Causa da variação } \\
\hline & Tratamento & Resíduo \\
\hline G.L. & 4 & 15 \\
\hline Q.M. & & \\
\hline M.O., $0-20 \mathrm{~cm}$ & 4,58297 n.s. & 9,05601 \\
\hline $\mathrm{pH}, 0-20 \mathrm{~cm}$ & 0,1086237 n.s. & 0,1130004 \\
\hline$P, 0-20 \mathrm{~cm}$ & 7.525,3784597 n.s. & $4.899,9396176$ \\
\hline $\mathrm{K}, 0-20 \mathrm{~cm}$ & 1,3467500 n.s. & 1,9721700 \\
\hline $\mathrm{Ca}, 0-20 \mathrm{~cm}$ & 264,5492200 n.s. & 210,15152 \\
\hline $\mathrm{Mg}, 0-20 \mathrm{~cm}$ & 57,5433500 n.s. & 49,1368100 \\
\hline $\mathrm{H}+\mathrm{Al}, 0-20 \mathrm{~cm}$ & 175,4877600 n.s. & 93,8507300 \\
\hline $\mathrm{SB}, 0-20 \mathrm{~cm}$ & 578,6743800 n.s. & 462,6335500 \\
\hline $\mathrm{T}, 0-20 \mathrm{~cm}$ & 277,5488600 n.s. & 301,1336600 \\
\hline $\mathrm{V}, 0-20 \mathrm{~cm}$ & 200,6425854 n.s. & 119,5239485 \\
\hline M.O., $20-40 \mathrm{~cm}$ & 8,6860800 n.s. & 7,2830500 \\
\hline $\mathrm{pH}, 20-40 \mathrm{~cm}$ & 0,0649989 n.s. & 0,0536253 \\
\hline$P, 20-40 \mathrm{~cm}$ & $1.058,9032954$ n.s. & 468,6869835 \\
\hline $\mathrm{K}, 20-40 \mathrm{~cm}$ & 1,2467500 n.s. & 3,3530000 \\
\hline $\mathrm{Ca}, 20-40 \mathrm{~cm}$ & 99,7255900 n.s. & 57,9943700 \\
\hline $\mathrm{Mg}, 20-40 \mathrm{~cm}$ & 4,4642800 n.s. & 9,8301600 \\
\hline $\mathrm{H}+\mathrm{Al}, 20-40 \mathrm{~cm}$ & 123,1044700 n.s. & 107,2173000 \\
\hline $\mathrm{SB}, 20-40 \mathrm{~cm}$ & 166,57441 n.s. & 107,61682 \\
\hline $\mathrm{T}, 20-40 \mathrm{~cm}$ & 235,17432 n.s. & 143,1001900 \\
\hline $\mathrm{V}, 20-40 \mathrm{~cm}$ & 68,3876653 n.s. & 60,1844938 \\
\hline
\end{tabular}


ANEXO B 
Tabela 37. Quadro da análise de variância do comprimento e área total de raízes visíveis nos perfis de acordo com os tratamentos de manejo do solo.

\begin{tabular}{lccc}
\hline Causa da Variação & G.L. & \multicolumn{2}{c}{ Q.M. } \\
\cline { 3 - 4 } & & Comprimento & Área \\
\hline Tratamento & 4 & $221.980,6125932$ n.s. & $8.166,5133977$ n.s. \\
Resíduo & 10 & $419.409,9599852$ & $14.682,3943482$ \\
\hline Total & 14 & & 36,96 \\
\hline C.V. (\%) & & 46,22 & \\
\hline
\end{tabular}

Tabela 38. Quadro da análise de variância da distância máxima atingida pelas raízes a partir do tronco de acordo com os tratamentos de manejo do solo.

\begin{tabular}{lccc}
\hline Causa da variação & G.L. & Q.M. & F \\
\hline Tratamento & 4 & 0,5458333 & $3,9697^{*}$ \\
Resíduo & 10 & 0,1375000 & \\
\hline Total & 14 & & \\
\hline
\end{tabular}


Tabela 39. Quadro da análise de variância da densidade de raízes de tangerina 'Poncã' enxertada sobre limão 'Cravo' por quadrícula (em cm/0,0625 ${ }^{2}$ ), de acordo com os fatores manejo, profundidade e distância do tronco.

\begin{tabular}{lcrc}
\hline Causa da Variação & G.L. & Q.M. & \multicolumn{1}{c}{ F } \\
\hline Manejo (A) & 4 & $4.268,8671697$ & $4,4789^{*}$ \\
Profundidade (B) & 3 & $19.887,9147994$ & $20,8665^{* *}$ \\
Distância (C) & 12 & $22.119,4233136$ & $23,2078 * *$ \\
A x B & 12 & $2.001,3654990$ & $2,0998^{*}$ \\
A x C & 48 & $1.744,4855653$ & $1,8303 * *$ \\
B x C & 36 & $1.545,1746419$ & $1,6212^{*}$ \\
A x B x C & 144 & 571,4126029 & 0,5995 n.s. \\
Resíduo & 520 & 953,1017129 & \\
\hline Total & 779 & & \\
\hline C.V. (\%) & 114,57 & & \\
\hline
\end{tabular}

n.s. = não significativo; ${ }^{*}=$ significativo a $5 \% ; * *$ significativo a $1 \%$.

Tabela 40. Quadro da análise da variância dos dados de densidade do solo e porosidade amostrados com anel, para as profundidades de $0-10,10-20$ e $20-40 \mathrm{~cm}$.

\begin{tabular}{lcc}
\hline \multicolumn{3}{c}{ Causa da variação } \\
\hline G.L. & Tratamento & Resíduo \\
\hline \multicolumn{1}{c}{ Q.M. } & 6 \\
Densidade, $0-10 \mathrm{~cm}$ & 0,0035114 n.s. & 0,0020777 \\
Porosidade, $0-10 \mathrm{~cm}$ & 0,0008649 n.s. & 0,0003005 \\
\hline Densidade, $10-20 \mathrm{~cm}$ & 0,0002332 n.s. & 0,0027889 \\
Porosidade, $10-20 \mathrm{~cm}$ & 0,0000224 n.s. & 0,0004142 \\
\hline Densidade, $10-20 \mathrm{~cm}$ & 0,0031000 n.s. & 0,0010333 \\
Porosidade, $10-20 \mathrm{~cm}$ & 0,0007304 n.s. & 0,0001912 \\
\hline
\end{tabular}

${ }^{1}$ : n.s. = não significativo; ${ }^{*}=$ significativo a $5 \% ; * *$ significativo a $1 \%$ 


\section{REFERÊNCIAS BIBLIOGRÁFICAS}




\section{REFERÊNCIAS BIBLIOGRÁFICAS}

ADAMS, T. M. The effects of agronomy on $\mathbf{C}$ and $\mathrm{N}$ distribution in soil organo-mineral fractions. Journal of Agricultural Science, v. 98, n.2, p. 335-342, 1982.

ANDERSON, D.W.; SAGGAR, S.; BETTANY, J.R.; STEWART, J.W.B. Particle size fractions and their use in studies of soil organic matter: $I$. The nature and distribution of forms of carbon, nitrogen and sulfur. Soil Science Society of America Journal, v. 45, n. 4, p. 767-772, 1981.

ANGERS, D.A.; SAMSON, N.; LÉGĖRE, A. Early changes in water-stable aggregation induced by rotation and tillage in a soil under barley production. Canadian Journal of Soil Science, v. 73, n.1, p. 51-59, 1993.

ANGULO, R.J.; ROLOFF, G.; SOUZA, M.L.P. Relações entre a erodibilidade e agregação, granulometria e características químicas de solos brasileiros. Revista Brasileira de Ciência do Solo, v. 8, n.1, p. 133-138, 1984.

ATKINSON, D. The distribution and effectiveness of the roots of trees crops. Horticultural Reviews, v. 2, p. 424-490, 1980.

AVILAN, L.; LEAL, F.; MENESES, L.; SUCRE, R.; GARCIA, M.L. Distribución del sistema radical de las cítricas en algunos suelos de Venezuela. Fruits, v. 41, n. 11, p. 655-668, 1986. 
AVILAN, L.; MENESES, L.; SUCRE, R.; PÉREZ, O.; BELARDI, C. Efecto de algunas propriedades fisicas del suelo sobre la distribucion radical y la produccion en citricas. Agronomía Tropical, v. 29, n. 5, p. 413-427, 1979.

BALESDENT, J.; PETRAUD, J.P.; FELLER, C. Effets des ultrasons sur la distribution granulométrique des matières organiques des sols. Science du Sol, v. 29, n. 2, p. 95106, 1991.

BÖHM, W. Methods of studying root systems. Berlin: Springer-Verlag, 1979. 188 p. (Ecological Studies, 33).

BOUMA, D.; McINTYRE, G.A. A factorial field experiment with citrus. Journal of Horticultural Science, v. 38, n.2, p. 175-198, 1963.

BRAGA, N.R. Adubação verde para os citros. Laranja, v. 7, n.1, p. 299-307, 1986.

BRUCKERT, S.; KILBERTUS, G. Fractionnement et analyse des complexes organominéraux de sols bruns et de chernozens. Plant and Soil, v.57, n.2, p. 271-295, 1980.

CAETANO, A.A. Tratos culturais. In: RODRIGUEZ,O; VIEGAS, F. Citricultura brasileira. Campinas: Fundação Cargill, 1980. v.2, p. 429-444.

CAETANO, A.A. Técnicas culturais mais recomendadas. In: SIMPÓSIO SOBRE PRODUTIVIDADE DE CITROS, 1., Jaboticabal, 1984. Anais. Jaboticabal: Fac. de Ciências Agrárias e Veterinárias, 1985. p 85-90. 
CAETANO, A.A. Nutrição e adubação dos citros. In: ENCONTRO PARANAENSE DE CITRICULTURA, 1., Londrina, 1986. Anais. Londrina: IAPAR, 1986. p. 105- 110 .

CALEGARI, A. Leguminosas para adubação verde de verão no Paraná. Londrina: IAPAR, 1995. 118p. (IAPAR. Circular, 80).

CAMBARDELLA, C.A.; ELLIOT, E.T. Carbon and nitrogen distribution in aggregates from cultivated and native grassland soils. Soil Science Society of America Journal, v. 57, n.4, p.1071-1076, 1993.

CARPENEDO, V.; MIELNICZUK, J. Estado de agregação e qualidade de agregados de latossolos roxos, submetidos a diferentes sistemas de manejo. Revista Brasileira de Ciência do Solo, v. 14, n.1, p. 99-105, 1990.

CARVALHO, J.E.B. de; BRITO, Z.U. de; COSTA NETO, A. de O.; CALDAS, R.C. Efeito de práticas culturais sobre o estabelecimento e permanência de fungos micorrízicos arbusculares (MAS) na laranja 'Pera'. Revista Brasileira de Fruticultura, v. 17, n. 3, p. 33-46, 1995.

CARY, P.R. The effects of tillage, non tillage and nitrogen on yield and fruit composition of citrus. Journal of Horticultural Science, v. 43, n.3, p. 299-315, 1968.

CASTLE, W.S. Fibrous root distribution of 'Pineapple' orange trees on Rough Lemon rootstock at three tree spacings. Journal of the American Society of Horticultural Science, v. 105, n. 3, p. 478-480, 1980. 
CASTLE, W.S.; TUCKER, D.P.H.; KREZDORN, A.H.; YOUTSEY, C.O. Rootstocks for Florida Citrus. Gainesville: University of Florida, Institute of Food and Agricultural Science, 1989. $47 \mathrm{p}$.

CASTRO, O.M. de.; LOMBARDI NETO, F. Manejo e conservação do solo em citros. Laranja, v. 13, n.1, p. 275-305, 1992.

CERRI, C.; FELLER, C.; BALESDANT, J.; VICTORIA, R.; PLENECASSAGNE, R. Application du traçage isotopique naturel en 13C, à l'éude de la dynamique de la matière organique dans les sols. C.R. Acad. Sc. Paris, série II, t.300, n.9, p. 423$428,1985$.

CHANEY, K.; SWIFT, R.S. The influence of organic matter on aggregate stability in some Brittish soils. Journal of Soil Science, v. 35, n.2, p. 223-230. 1984.

CHRISTENSEN, B.T. Decomposibility of organic matter in particle size fractions from field soils with straw incorporation. Soil Biology and Biochemistry, v. 19, n. 4, p. 429-435, 1987.

CHRISTENSEN, B.T. Effect of animal manure and mineral fertilizer on the total carbon and nitrogen contents of soil size fractions. Biology and Fertility of Soils, v. 5, n.4, p. 304-307, 1988.

CHRISTENSEN, B.T. Physical fractionation of soil orgaic matter in primary particle size and density separates. Advances in Soil Science, v.20, p.1-19, 1992.

CINTRA, F.L.D.; COELHO, Y da S. Caracterização fisica do solo em pomares da região citrícola do recôncavo baiano. Revista Brasileira de Fruticultura, v. 9, n. 1, p. $27-35,1987$. 
CINTRA, F.L.D.; COELHO, Y da S.; CUNHA SOBRINHO, A.P.; PASSOS, O.S. Caracterização fisica do solo submetido a práticas de manejo em pomar de Laranja "Baianinha". Pesquisa Agropecuaria Brasileira, v. 18, n. 2, p. 173-179, 1983.

CINTRA, F.L.D.; NEVES, C.S.V.J. Aspectos metodológicos do estudo do sistema radicular de plantas perenes através de imagens. Boletim Informativo da Sociedade Brasileira de Ciência do Solo, v. 21, n. 3, p. 91-94, 1996.

COELHO, Y.da S. O uso de grade de discos na citricultura. Cruz das Almas: EMBRAPA, CNPMF, 1991. 2 p. (Citros em Foco, 16).

CORRÊA, A.R.; GODOY, H.; BERNARDES, A.R.M. Características climáticas de Londrina. 2.ed. Londrina: IAPAR, 1982. 16 p. (Circular IAPAR, 5).

CRESTANA, S.; GUIMARÃES, M.F.; JORGE, L.A.C.; RALISCH, R.; TOZZI, C.L.; TORRE, A.; VAZ, C.M.P. Avaliação da distribuição de raízes no solo auxiliada por processamento de imagens digitais. Revista Brasileira de Ciência do Solo, v. 18, n.2, p. 365-371, 1994.

DALAL, R.C.; MAYER, R.J. Long-term trends in fertility of soils under continuous cultivation and cereal cropping in southern Queenland. III. Distribution and kinetics of soil organic carbon in particle-size fractions. Australian Journal of Soil Research, v. 24, n.2, p. 293-300, 1986.

DANIELSON, R.E.; SUTHERLAND, P.L. Porosity. In: KLUTE, A. (Ed.). Methods of soil analysis. Madison: American Society of Agronomy, 1986. Part 1. p. 443461. 
DESJARDINS, T.; ANDREUX, F.; VOLKOFF, B.; CERRI, C.C. Organic carbon and ${ }^{13} \mathrm{C}$ contents in soils and soil size-fractions, and their changes due to deforastation and pasture installation in eastern Amazonia. Geoderma, v.61, n. 1/2, p. 103-118, 1994.

DEMATTÊ, J.L.; VITTI, G.C. Alguns aspectos relacionados ao manejo de solos para citros. In: SEMINÁRIO INTERNACIONAL DE CITROS, 2., Bebedouro, 1992. Anais. Campinas: Fundação Cargill, 1992. p. 67-99.

DONADIO, L.C.; VITTI, G.C.; DURIGAN, J.C.; BANZATTO, D.A.; CABRITA, J.R.M. Estudos de adubação e tratos culturais em citros na E.E. de citricultura de Bebedouro. Laranja, v. 7, n.1, p. 291-298, 1986.

DORNELLES, C.M.M. Manejo de solos em pomares de laranjeiras no Rio Grande do Sul. Agronomia Sul-Riograndense, v.7, n.2, p.91-98, 1971.

DREW, M.C. Root function, development, growth and mineral nutrition. In: LYNCH, J.M. The rhizosphere. Chichester: John Wiley, 1990. cap. 3, p. 35-57.

EMPRESA BRASILEIRA DE PESQUISA AGROPECUÁRIA. Manual de métodos de análise de solo. Rio de Janeiro, SNLCS, 1979. n.p.

FAHAD,A.A.; MELKE, L.N.; FLOWERDAY, A.D.; SWATZENDRUBER, D. Soil physical properties as affected by soybean and other cropping sequences. Soil Science Society of America Journal, v. 46, n.2, p. 377-381, 1982.

FEIGL, B.J.; MELILLO, J.; CERRI, C.C. Changes in the origin and quality of soil organic matter after pasture introduction in Rondônia (Brazil). Plant and Soil, v. 175 , n.1, p. 21-29, 1995. 
FELLER, C. Effet des différents systèmes de culture sur les stocks organiques de sols argileux tropicaux des Petites Antilles. Cahiers ORSTOM. Sér. Pédologie, v. 24, n. 4, p. 341-343, 1988.

FELLER, C. Organic inputs, soil organic matter and functional soil orgamic compartments in low-activity clay soils in tropical zones. In: MULONGOY, K.; MERCKX, R. (ed.) Soil organic matter and sustainability of tropical agriculture. Chichester: Willey-Sayce, 1993. p. 77-88.

FELLER, C. La matière organique du sol et la recherche d'indicateurs de la durabililité des sistèmes de culture dans les régions tropicales semi-arides et subhumides d'Afrique de l'Ouest. In: GANRY, F.; CAMPBELL, B. (Eds.). Sustainable land management in African semi-arid and subhumic regions. Montpellier: CIRAD, 1995 a. p. $123-130$.

FELLER, C. La matière organique dans les sols tropicaux à argile 1: 1; recherche de compartiments organiques fonctionnels: une approche granulométrique. Paris: ORSTOM, 1995 b, (Coll. Tdm-ORSTOM, 144).

FELLER, C.; ALBRECHT, A.; TESSIER, D. Aggregation and organic matter storage in kaolinitic and smectitic tropical soils. In: CARTER, M.R.; STEWART, B.A. (Ed.). Structure and organic matter storage in agricultural soils. Boca Raton: Lewis, 1995. p.309-359.

FELLER, C.; BURTIN, G.; GERARD, B.; BALESDENT, J. Utilisation des résines sodiques et des ultrasons dans le fractionnement granulométrique de la matière organique des sols, intérêt et limites. Science du Sol, v. 29, n. 2, p. 77-93, 1991 a. 
FELLER, C.; FRITSCH, E.; POSS, R.; VALENTIN, C. Effet de la texture sur le stockage et la dynamique des matières organiques dans quelques sols ferrugineux et ferrallitiques (Afrique de l'Ouest, en particulier). Cahiers ORSTOM, Sér. Pédologie. v. 26, n. 1, p. 25-36, 1991 b.

FELLER, C.; LAVELLE, P.; ALBRECHT, A.; NICOLARDOT, B. La jachère et le fonctionnement des sols tropicaux; rôle de l'activité biologique et des matières organiques; quelques éléments de réflexion. In: ORSTOM (Ed.) La jachère en Afrique de l'ouest. Paris: ORSTOM, 1993. p.15-33.

FELLER, C.; BERNHARDT-REVERSAT, F.; GARCIA, J.L.; PANTIER, J.J.; ROUSSOS, S.; VLIET-LANOE, B.V. Étude de la matière organique de différents fractions granulométriques d'un sol sabeux tropical. Effet d'un amendement organique (compost). Cahiers ORSTOM. Sér. Pédologie, v. 20, n. 3, p. 223-238, 1983.

FIES, J.C.; CASTELAO-GEGUNDE, A.M. Analyse de la repartition du volume des pores dans les assemblages argile-squelettes: comparaison entre un modèle d'espace poral textural et les données fournies para la porosimétrie au mercure. Agronomie, v. 4, n.9, p. 891-899, 1996.

FORD, H.W. Effect of spreading decline disease on the distribution of feeder roots of orange and grapefruit trees on rough lemon rootstock. Proceedings of the American Society for Horticultural Science, v. 61, p. 68-72, 1953.

FORD, H.W. The influence of rootstock and tree age on root distribution of Citrus. Proceedings of the American Society for Horticultural Science, v. 63, p. 137$142,1954$. 
FREITAS, P.L.de; BLANCANEAUX, P.; GAVINELLI, E.; LARRÉ-LARROUY, M.C.; FELLER,C. Efeito de diferentes sisntemas de uso e manejo sobre o nivel e a natureza do estoque orgânico de latossolos argilosos de cerrados do Brasil. Pesquisa Agropecuária Brasileira, 1997. (no prelo)

FRITH, H.J. Some effects of no cultivation on the yield and growth of citrus trees. Australian Journal of Agricultural Research, v. 3, p. 259-276, 1952.

GALLO, J.R.; RODRIGUEZ, O. Efeito de algumas práticas de cultivo do solo na nutrição mineral dos citros. Bragantia, v.19, n. 23, p. 345-360, 1960.

GAUTRONNEAU, Y.; MANICHON, H. Guide methodique du profil cultural. Paris: CEREF/GEARA, 1987. $71 \mathrm{p}$.

GAVINELLI, E.; FELLER, C.; LARRE-LARROUY, M.C.; BACYE, B.; DJEGUI, N.; NZILA, J. de . A routine method to study soil organic matter by particle size fractionation: examples for tropical soils. Communications in Soil Science and Plant Analysis, v. 26, n. 11/12, p. 1749-1760, 1995.

GIJSMAN, A.J.; THOMAS, R.J. Aggregate size distribution and stability of an oxisol under legume-based and pure grass pastures in the eastern colombian savannas. Australian Journal of Soil Research, v. 33, n.1, p. 153-165, 1995.

GODEFROY, J.; BOURDEAUT, T. Action des plantes de couverture sur les caractéristiques chimiques, biologiques et structurales d'un sol de verger de Côte d'Ivoire. Fruits, v. 27, n. 5, p. 349-353, 1972. 
GREACEN, E.L.; PERKMAN, O. Soil-structure changes in a long-term citrus experiment. Australian Journal of Agricultural Research, v. 4, n. 2, p. 193-203, 1953.

GREENLAND, D.J. The physics and chemistry of the soil-root interface: some comments. In: HARLEY, J.L.; RUSSEL, R.S. The soil-root interface. New York: Academic Press, 1979. p 83-98.

GREGORY, P.J. Growth and fncioting of plant roots. In: WILD, A. Russell's soil conditions and plant growth. 17.ed. New York: Jonh Wiley, 1988. cap. 4, p. 113167.

GRUPO PAULista DE ADUBAÇÃO E CALAGEM PARA Citros. Recomendações de adubação e calagem para citros no Estado de São Paulo. Laranja, v.9, n.3, p.1-15,1988. Suplemento Especial.

HAMBLIN, J. The influence of soil structure on water movement, crop root growth and water uptake. Advances in Agronomy, v. 38, p. 95- 158, 1985.

HAYNES, R.J.; FRANCIS, G.S. Changes in microbial biomass C, soil carbohydrate composition and aggregate stability induced by growth of selected crop and forage species under field conditions. Journal of Soil Science, v. 44, p 665-675, 1993.

HAYNES, R.J.; SWIFT, R.S.; STEFEN, R.C. Influence of mixed cropping rotations (pasture-arable) on organic matter content, water stable aggregation and clod porosity in a group of soils. Soil \& Tillage Research, v. 19, p. 77-87, 1991.

HIROCE, R.; GALLO, J.R.; TEÓFILO SOBRINHO, J.; POMPEU JÚNIOR, J. Influência de porta-enxertos na composição mineral das folhas e das frutas de 
laranjeira 'Valência' e tangerina 'Poncã'. In: CONGRESS OF THE TROPICAL REGION, 29., Campinas, 1981. Proceedings. Campinas: American Society of Horticultural Science, 1981. p. 155-162.

HOGUE, E.J.; NEILSEN, G.H. Orchard floor vegetation management. Horticultural Reviews, v. 9, p. 377-430, 1987.

INSTITUTO ADOLFO LUTZ. Normas analíticas do Instituto Adolfo Lutz. 3 ed. São Paulo, 1985. v.1, 533 p.

JONES, W.W.; EMBLETON, T.W. Soils, soil management, and cover crops. In: REUTHER, W. The citrus industry. Riverside: University of California, 1973. v.3, cap 4, p. 98-121.

KARLEN, D.L.; CAMBARDELLA, C.A. Conservation strategies for improveing soil quality and organic matter storage. In: CARTER, M.R.; STEWART, B.A. (ed.) Structure and organic matter storage in agricultural soils. Boca Raton: Lewis, 1995. p.395-420.

KARLEN, D.L.; MAUSBACH, M.J.; DORAN, J.W.; CLINE, R.G.; HARRIS, R.F.; SCHUMAN, G.E. Soil quality: a concept, definition, and framework for evalution (a guest editorial). Soil Science Society of America Journal, v.61, n.1, p. 4-10, 1997.

KAUFMANN, M.R.; BOSWELL, S.B.; LEWIS, L.N. Effect of tree spacing on root distribution of 9-year old 'Washington' navel oranges. Journal of American Society of Horticultural Science, v. 97, n. 2, p. 204-206, 1972. 
KEMPER, W.D.; ROSENAU, R.C. Aggregate stability and size distribution. In: KLUTE, A. Methods of soil analysis. 2. ed. Madison: American Society of Agronomy, 1986. pt 1: Physical and mineralogical methods, p.425-443.

KOLLER, O.C.; BARRADAS, C.I.N.; PEREIRA, A. Efeito de dois sistemas de manejo do solo sobre a produção de duas variedades de laranjeira doce Citrus sinensis Osb. In: CONGRESSO BRASILEIRO DE FRUTICULTURA, 4., Salvador, 1977. Anais. Salvador: Soc. Bras. de Fruticultura, 1977. p.183-190.

KOUAKOUA, E. La matière organique et la stabilité structurale d'horizons de surface de sols ferrallitiques argileux. Effet du mode de gestion des terres. Nancy, 1998. 221 p. Thèse (Docteur) - Faculté de Sciences, Université Henri Poincaré, Nancy 1.

KOUAKOUA, E.; SALA, G.H.; BARTHES, M.C.; LARRE-LARROUY, M.C., ALBRECHT, A.; FELLER, C. La matière organique soluble à l'eau chaude et la stabilité de l'agregation. Aspects méthodologiques et application à des sols ferralitiques du Congo. European Journal of Soil Science, v.48, p. 239-247, 1997.

LEINWEBWER, P.; REUTER, G. The influence of different fertilization practices on concentrations of organic carbon and total nitrogen in particle-size fractions during 34 years of a soil formation experiment in loamy marl. Biology and Fertility of Soils, v. 13, n.2, p. 119-124, 1992.

LEITE, N.; GIACOMETTI, D.C. Influência do sistema de manejo do solo em laranjal sobre as qualidades da fruta. In: REUNIÃO ANUAL DA SOCIEDADE BOTÂNICA DO BRASIL, 11, Belo Horizonte, 1960. Anais. Belo Horizonte: Sociedade Botânica do Brasil, 1960. v. 1. p. 41-45. 
LEPSCH, I.F.; MENK, J.R.F.; OLIVEIRA, J.B. Carbon storage and other properties of soils under agriculture and natural vegetation in São Paulo State, Brazil. Soil Use and Management, v. 10, p. 34-42, 1994.

LEPSCH, I.F.; SILVA, N.M da.; ESPIRONELO, A. Relação entre matéria orgânica e textura de solos sob cultivo de algodão e cana-de-açúcar, no Estado de São Paulo, Bragantia, v. 41, p. 231-236, 1982.

MALAVOLTA, E.; VIOLANTE NETTO, A. Nutrição mineral, calagem, gessagem e adubação dos citros. Piracicaba: POTAFOS, 1989. 153p.

MANICHON, H. Observation morphologique de l'état structural et mise en évidence d'effets de compactage des horizons travaillés. In: MONNIER, G.; GOSS, M.J. Soil compaction and regeneration. Rotterdan: A.A. Balkema, 1987. p. 39-52.

MARTINEZ, A.A.; RODRIGUEZ, O.; INFORZATO, R.; ABRAIDES, E. Influência de nove práticas de cultivo do solo no sistema radicular de laranjeiras - Hamlin enxertadas em laranjeira-caipira. In: REUNIÃO ANUAL DA SOCIEDADE BRASILEIRA PARA O PROGRESSO DA CIÊNCIA, 12., Salvador, 1970. Resumos. Salvador: SBPC, 1970. p. 221.

MAZZA, J.A.; VITTI, G.C.; PEREIRA, H.S.; MENEZES, G.M.; TAGLIARINI, C.H. Influência da compactação no desenvolvimento do sistema radicular de citrus: sugestão de método qualitativo de avaliação e recomendações de manejo. Laranja, v. 15, n. 2 , p. $263-275,1994$.

MENEGUCCI, J.L.P.; AMARAL, A.M. do; SOUZA, M. de. Alterações das propriedades químicas do solo na camada subsuperficial após adubação verde com crotalária. Revista Brasileira de Fruticultura, v. 17, n. 3, p. 7-12, 1995. 
MONTENEGRO, H.W.S. Contribuição ao estudo do sistema radicular das plantas cítricas. Piracicaba, 1960. 143p. Tese (Cátedra) - Escola Superior de Agricultura "Luiz de Queiroz", Universidade de São Paulo.

MOREIRA, C.S. Estudo da distribuição do sistema radicular da laranjeira 'Pêra'(Citrus sisnensis, Osbeck) com diferentes manejos do solo. 1983a. 97p. Tese (Livredocência) - Escola Superior de Agricultura 'Luiz de Queiroz", Universidade de São Paulo.

MOREIRA, C.S. Manejo do solo para citros. Laranja, v. 4, p. 345-351. $1983 b$.

MOREIRA, C.S. O sistema radicular das plantas cítricas. In: In: SEMINÁRIO INTERNACIONAL DE CITROS, 2., Bebedouro, 1992. Anais. Campinas: Fundação Cargill, 1992. p. 182-186.

MORTLAND, M.M. Mechanisms of adsorption of nonhumic organic species by clays. In: HUANG, P.M.; SCHNITZER, M. (Ed.). Interactions of soil minerals with natural organics and microbes. Wisconsin: SSSA, 1986. p.59-75.

MUSTAFFA, M.M. Effects of orchard management practices on yield, quality and leaf nutrient content of Coorg mandarin. Journal of Horticultural Science, v. 63, n.4, p. 711-716, 1988.

NEGRI, J.D. de. Práticas culturais para o aumento da produtividade dos citros. In: SIMPÓSIO DE CITRICULTURA, 3., Jaboticabal, 1988. Anais. Jaboticabal: FUNEP, 1988. p. 205-219. 
NEVES, C.S.V.J. ; GONZALEZ, M.G.N. Efeito do manejo do solo sobre o crescimento das plantas de tangerineira "Ponkan"(Citrus reticulata Blanco) no período de formação do pomar. Revista Brasileira de Fruticultura, v. 14, n. 2, p. 41-46, 1992.

NILO GONZALEZ, M.G.; NEVES, C.S.V.J. Manejo de solo e sua influência sobre a produção e qualidade dos frutos nas primeiras safras de tangerineira "Ponkan"(Citrus reticulata Blanco). Revista Brasileira de Fruticultura, v. 14, n. 2, p. 71-77, 1992.

OADES, J.M. The role of biology in the formation, stabilization and degradation of soil structure. Geoderma, v.56, p.377-400, 1993.

OADES, J.M.; WATERS, A.G. Aggregate hierarchy in soils. Australian Journal of Soil Research, v. 29, n.6, p. 815-828, 1991.

OLIVEIRA, J.B. Solos para citros. In: RODRIGUEZ, O.; VIÉGAS, P.; POMPEU JR., J.; AMARO, A.A. (Ed.) Citricultura brasileira. Campinas: Fundação Cargill, 1991. v.1, p. 196-227.

ORTOLANI, A.A.; PEDRO JÚNIOR, M.J.; ALFONSI, R.R. Agroclimatologia e o cultivo dos citros. In: RODRIGUEZ, O.; VIÉGAS, F.; POMPEU JÚNIOR, J.; AMARO, A.A. Citricultura brasileira. 2. ed. Campinas: Fundação Cargill, 1991. v.1, p. 153-195.

PACE, C.A.M.; ARAÚJO,C.M. Estudo da distribuição do sistema radicular de portaenxertos cítricos em solos podzolizados e sua relação com a formação de copas. In:CONGRESSO BRASILEIRO DE FRUTICULTURA, 8., Brasília, 1986. Anais. Brasília: Soc. Bras. de Fruticultura, 1986. v.1, p. 199-205. 
PACHECO, E.B.; SANTOS, H.L. dos; TEIXEIRA, S.L.; CARDINALLI, L.R.; FELDMANNJ, R. de O. Manejo do solo sob cerrado em pomar de Citrus e sua influência sobre o crescimento das plantas e produção de frutos. Pesquisa Agropecuária Brasileira. Sér. Agron., v.8, p. 109-113, 1973.

PAGLIAI, M. Micromorphometric and micromorphological investigations on the effect of compaction by pressures and degformations resulting from tillage wheel traffic. In: MONNIER, G.; GOSS, M.J. Soil compaction and regeneration. Rotterdan: A.A. Balkema, 1987. p. 31-38.

PARKER, M.L.; MEYER, Peach tree vegetative and root growth respond to orchard floor management. Hortscience, v. 31, n.3, p. 330-333, 1996.

PARKER, M.L.; HULL, J.; PERRY, R.L. Orchard floor management affects peach rooting. Journal of the American Society for Horticultural Science, v. 118, n. 6, p. 714-718, 1993.

PASSOS, O.S.; CUNHA SOBRINHO, A.P. da; COELHO, Y. da S. Manejo do solo em pomar de citros. In: CONGRESSO BRASILEIRO DE FRUTICULTURA, 2., Viçosa, 1973. Anais. Viçosa: Sociedade Brasileira de Fruticultura, 1973. v.1, p. 249-256.

PEARSON, R.W. Significance of rooting pattern to crop production and some problems of root research. In: CARSON, E.W. The plant root and its environment. Charlottesville: Univ. Press Virginia, 1971. p.247-267.

PÉDRO, G.; CHAUVEL, A.; MELEI, J. Recherches sur la constitution et la genèse des Terra Roxa Estruturada du Brésil. Annalles Agronomiques, v. 27, n.3, p.265-294, 1976. 
PLATT, R.G. Planning and planting the orchard. In: REUTHER, W. The citrus industry. Riverside: University of California, 1973. v. 3, p. 48-81.

PROEBSTING, E.L. Some effects of a long continued covercropping in a California orchard. Proceedings of the American Society for Horticultural Science, v. 60, p. 87-90, 1952.

RAIJ, B.van.; QUAGGIO, J.A.; CANTARELLA, H.; FERREIRA, M.E.; LOPES, A.S.; BATAGLIA, O.C. Análise química do solo para fins de fertilidade. Campinas: Fundação Cargill, 1987. 170p.

REUTHER, W. The citrus industry. Riverside: Univ. of California, 1973. v. 3, cap. 9, p.280-337: Climate and citrus behavior.

ROCHA, G.C.; BARROS, O.N.F.; GUIMARÃES, M. de F. Distribuição espacial e características dos solos do Campus da Universidade Estadual de Londrina, PR. Semina, v. 12, n. 1, p. 25-37, 1991.

RODRIGUEZ, O. Manejo do solo em pomar cítrico. O Agronômico, v.9, n.11/12, p.17-24, 1957.

RODRIGUEZ, O. Problemas de ervas daninhas em pomares cítricos do Estado de São Paulo. In: CONGRESSO NACIONAL DE BOTÂNICA, 20., Goiânia, 1969, Anais. Goiânia: Soc. Botânica do Brasil, 1969. p.19-23.

RODRIGUEZ, O.; MOREIRA, S.; ROESSING, C. Estudo de nove práticas de cultivo em pomar cítrico no planalto paulista. In: SEMINÁRIO BRASILEIRO DE 
HERBICIDAS E ERVAS DANINHAS, 5., Cruz das Almas, 1964. Anais. Cruz das Almas: Inst. de Pesq. Agropec. do Leste, 1964. p.257-258.

ROTH, C.H.; CASTRO FILHO, C.de; MEDEIROS, G.B.de Análise de fatores fisicos e químicos relacionados com a agregação de um latossolo roxo distrófico. Revista Brasileira de Ciência do Solo, v. 15, n.3, p. 241-248, 1991.

RUFINO, R.L.; MUZZILI; PAVAN, M. A. A citricultura no Paraná. Londrina: IAPAR, 1992. cap. 3, p.53-88: Manejo do solo. (IAPAR. Circular, 72).

RUSSEL, R.S. Plant root systems - their functioon and interaction with the soil. In: RUSSEL, R.S.; IGHE, K.; MEHTA, Y.R. The soil/root system in relation to brazilian agriculture. Londrina: Fundação Instituto Agronômico do Paraná, 1981. p. 3-19.

SÁNCHEZ, A.; BASCONES, L.; ROSALES, A. Evaluacion de tierras para el cultivo del naranjo. I. Principales caracteristicas edaficas que determinan la aptitud de suelos para el naranjo. Agronomia Tropical, v. 38, n.1-3, p. 73-84, 1988.

SANCHEZ, P.A. Suelos del Tropico: caracteristicas y manejo. San José: IICA. 1981. $634 p$.

SANTINONI, L.A.; SILVA, N.R. Crescimiento, producción y maduración del mandarino comúnn bajo diferentes prácticas de manejo de suelo. Horticultura Argentina, v. 14, n. 36, p. 5-11, 1995.

SÃO JOSÉ, A.R.; DONADIO, L.C.; DURIGAN, J.C.; BANZATTO, D.A.; CABRITA, J.R.M. Estudo de tratos culturais na formação de pomar cítrico. In: CONGRESSO 
BRASILEIRO DE FRUTICULTURA, 9., Campinas, 1987, Anais. Campinas: Soc. Bras. de Fruticultura, 1988. v.1, p. 383-386.

SARRUGE, J.R.; HAAG, H.P. Análise química em plantas. Piracicaba: ESALQ/USP, 1974. $56 \mathrm{p}$.

SCHNITZER, M. Binding of humic substances by mineral colloids. In: HUANG, P.M.; SCHNITZER, $M$ (Ed.). Interactions of soil minerals with natural organics and microbes. Wisconsin: SSSA, 1986. p.77-101.

SILVA, J.J.A. Consorciação de adubos verdes na cultura dos citros em formação. Piracicaba. 1995. 116 p. Dissertação (Mestrado) - Escola Superior de Agricultura Luiz de Queiróz, Universidade de São Paulo.

SCHULTEN, H.R.; LEINWEBWER, P. Influence of long-term fertilization with farmyard manure on soil organic matter: characteristics of particle-size fractions. Biology and Fertility of Soils, v.12, n.2, p. 81-88, 1991.

TARDIEU, F.; MANICHON, H. Caractérisation en tant que capteur d'eau de l'enracinement du maïs en parcelle cultivée. II.- Une méthode d'étude de la répartition verticale et horizontale des racines. Agronomie, v. 6, n.5, p. 415-425, 1986.

TARDIEU, F.; MANICHON, H. Conséquences de l'état du profil cultural sur l'enracinement: cas du maïs. In: MONNIER, G.; GOSS, M.J. Soil compaction and regeneration. Rotterdan: A.A. Balkema, 1987. p.131-143.

TAVARES FILHO, J.; GUIMARÃES, M. de F.; MEDINA, C. de C.; RALISH, R. Método do Perfil Cultural: adaptação e utilização nos estudos de manejo em solos 
tropicais. In: SIMPÓSIO DE INSTRUMENTAÇÃO AGROPECUÁRIA, 1., Anais. São Carlos, 1997. p.490-495.

TIESSEN, H.; STEWART, J.W.B. Particle size fractions and their use in studies of soil organic matter: II: Cultivation effects on organic matter composition in size fractions. Soil Science Society of America Journal, v. 47, n.3, p. 509-513, 1983.

TISDALL, J.M. \& OADES, J.M. Stabilization of soil aggregates by the root systems of ryegrass. Australian Journal of Soil Resarch, v. 17, n.3, p.429-441, 1979.

TISDALL, J.M.; OADES, J.M. Organic matter and water-stable aggregates in soil. Journal of Soil Science, v. 33, p. 141-163, 1982.

TUCKER, D.P.H. ; MURARO, R.; ABBIT, B. Two weed control systems for Florida citrus. Proceedings of Florida State Horticultural Society, v. 93, p. 30-33, 1980.

VASCONCELlOS, H. de O.; ARAÚJO, C.M.; BRITTO, D.P.P. de S. Manejo do solo em pomar de laranja Pera (Citrus sinensis). Pesquisa Agropecuária Brasileira. Sér. Agron., v. 11, p. 43-48, 1976.

VASCONCELLOS, P.W.C. Adubos verdes nos pomares velhos. Revista de Agricultura, v.7, p. 99-102, 1932.

VICTORIA FILHO., R. Uso de herbicidas em citros, beneficios e problemas. Laranja, v. 9, n.2, p. $423-435,1988$.

VITTI, G.C. ; SILVA, M.M. Adubação verde e orgânica na citricultura. Laranja \& Cia, n. 44, p.6-8, 1996. 
WEBSTER, D.H. Soil conditions associated with absence or sparse development of apple roots. Canadian Journal of Plant Science, v. 58, n.3, p. 961-969, 1978.

WELLER, F. A method for studying the distribution of absorbing roots of fruit trees. Experimental Agriculture, v. 7, p. 351-361, 1971.

WYSS, R.E. The influence of cultivation and weed control in jamaican citrus. Proceedings of Florida State Horticultural Society, v. 75, n.2, p. 63-67, 1962.

ZACHAR, D. Soil erosion. Amsterdam: Elsevier, 1982. 547 p. 
APÊNDICE 
Tabela 41. Dados meteorológicos da região de Londrina-Pr, durante a realização do trabalho: médias mensais de temperatura máxima, mínima e média $\left({ }^{\circ} \mathrm{C}\right)$, umidade relativa (\%) e total mensal de precipitação $(\mathrm{mm})$ durante o ano de 1991.

\begin{tabular}{rrrrrr}
\hline mês & $\begin{array}{r}\text { t. } \\
\text { máx. } \\
\left({ }^{\circ} \mathrm{C}\right)\end{array}$ & $\begin{array}{r}\text { t. mín. } \\
\left({ }^{\circ} \mathrm{C}\right)\end{array}$ & $\begin{array}{r}\text { t. méd. } \\
\left({ }^{\circ} \mathrm{C}\right)\end{array}$ & $\begin{array}{r}\text { U.R. } \\
(\%)\end{array}$ & $\begin{array}{r}\text { Precipit. } \\
(\mathrm{mm})\end{array}$ \\
\hline 1 & 29,6 & 19,2 & 24,0 & 73,6 & 223,6 \\
2 & 29,7 & 18,5 & 23,5 & 72,3 & 58,0 \\
3 & 27,7 & 18,5 & 22,4 & 79,7 & 179,3 \\
4 & 27,6 & 16,4 & 21,3 & 75,2 & 92,4 \\
5 & 25,1 & 13,4 & 18,8 & 70,4 & 11,1 \\
6 & 23,5 & 13,1 & 17,8 & 75,1 & 155,1 \\
7 & 23,3 & 10,4 & 16,3 & 65,4 & 24,0 \\
8 & 26,0 & 13,6 & 19,1 & 61,5 & 18,1 \\
9 & 27,1 & 14,8 & 20,6 & 58,3 & 96,2 \\
10 & 28,7 & 16,8 & 22,1 & 65,2 & 47,1 \\
11 & 30,1 & 18,0 & 23,4 & 61,8 & 272,8 \\
12 & 29,5 & 19,6 & 23,8 & 74,9 & 264,4 \\
\hline
\end{tabular}


Tabela 43. Dados meteorológicos da região de Londrina-Pr, durante a realização do trabalho: médias mensais de temperatura máxima, mínima e média $\left({ }^{\circ} \mathrm{C}\right)$, umidade relativa (\%) e total mensal de precipitação (mm) durante o ano de 1992.

\begin{tabular}{rrrrrr}
\hline mês & $\begin{array}{r}\text { t. } \\
\text { máx. } \\
\left({ }^{\circ} \mathrm{C}\right)\end{array}$ & $\begin{array}{rrrr}\text { t. mín. } \\
\left({ }^{\circ} \mathrm{C}\right)\end{array}$ & $\begin{array}{r}\text { t. méd. } \\
\left({ }^{\circ} \mathrm{C}\right)\end{array}$ & $\begin{array}{r}\text { U.R. } \\
(\%)\end{array}$ & $\begin{array}{r}\text { Precipit. } \\
(\mathrm{mm})\end{array}$ \\
\hline 1 & 31,0 & 19,4 & 24,7 & 64,8 & 45,4 \\
2 & 29,5 & 19,9 & 24,2 & 73,0 & 277,5 \\
3 & 27,6 & 18,6 & 22,1 & 83,7 & 362,9 \\
4 & 26,7 & 15,9 & 20,2 & 77,1 & 149,3 \\
5 & 24,1 & 15,1 & 18,8 & 83,2 & 286,6 \\
6 & 24,3 & 14,0 & 18,6 & 76,4 & 27,6 \\
7 & 21,9 & 10,5 & 15,7 & 74,5 & 41,5 \\
8 & 23,6 & 11,5 & 17,0 & 70,1 & 39,6 \\
9 & 24,3 & 14,2 & 18,7 & 75,2 & 193,4 \\
10 & 27,9 & 16,9 & 21,7 & 71,4 & 157,2 \\
11 & 29,0 & 17,2 & 22,5 & 68,6 & 236,2 \\
12 & 30,0 & 18,5 & 24,0 & 66,0 & 59,4 \\
\hline
\end{tabular}


Tabela 43. Dados meteorológicos da região de Londrina-Pr, durante a realização do trabalho: médias mensais de temperatura máxima, mínima e média $\left({ }^{\circ} \mathrm{C}\right)$, umidade relativa (\%) e total mensal de precipitação $(\mathrm{mm})$ durante o ano de 1993.

\begin{tabular}{rrrrrr}
\hline mês & t. $\begin{array}{r}\text { máx. } \\
\left({ }^{\circ} \mathrm{C}\right)\end{array}$ & $\begin{array}{rrrr}\text { t. mín. } \\
\left({ }^{\circ} \mathrm{C}\right)\end{array}$ & $\begin{array}{r}\text { t. méd. } \\
\left({ }^{\circ} \mathrm{C}\right)\end{array}$ & $\begin{array}{r}\text { U.R. } \\
(\%)\end{array}$ & $\begin{array}{r}\text { Precipit. } \\
(\mathrm{mm})\end{array}$ \\
\hline 1 & 30,5 & 19,7 & 24,2 & 74,8 & 296,9 \\
2 & 27,2 & 18,5 & 22,2 & 81,5 & 291,2 \\
3 & 30,0 & 18,8 & 23,6 & 73,9 & 65,1 \\
4 & 28,7 & 17,2 & 22,3 & 73,4 & 128,7 \\
5 & 24,8 & 13,7 & 18,5 & 75,2 & 125,9 \\
6 & 22,3 & 11,1 & 16,0 & 79,4 & 97,8 \\
7 & 23,1 & 11,2 & 16,3 & 71,3 & 43,0 \\
8 & 25,2 & 12,7 & 18,2 & 63,6 & 14,8 \\
9 & 25,4 & 15,3 & 19,7 & 74,6 & 171,4 \\
10 & 29,2 & 17,7 & 22,9 & 65,9 & 120,8 \\
11 & 31,5 & 18,3 & 24,4 & 58,4 & 89,7 \\
12 & 29,6 & 19,4 & 23,8 & 74,6 & 313,4 \\
\hline
\end{tabular}


Tabela 44. Dados meteorológicos da região de Londrina-Pr, durante a realização do trabalho: médias mensais de temperatura máxima, mínima e média $\left({ }^{\circ} \mathrm{C}\right)$, umidade relativa (\%) e total mensal de precipitação (mm) durante o ano de 1994.

\begin{tabular}{rrrrrr}
\hline mês & $\begin{array}{r}\text { t. máx. } \\
\left({ }^{\circ} \mathrm{C}\right)\end{array}$ & $\begin{array}{r}\text { t. mín. } \\
\left({ }^{\circ} \mathrm{C}\right)\end{array}$ & $\begin{array}{r}\text { t. méd. } \\
\left({ }^{\circ} \mathrm{C}\right)\end{array}$ & $\begin{array}{r}\text { U.R. } \\
(\%)\end{array}$ & $\begin{array}{r}\text { Precipit. } \\
(\mathrm{mm})\end{array}$ \\
\hline 1 & 29,2 & 19,0 & 23,3 & 74,7 & 209,5 \\
2 & 30,8 & 20,5 & 24,5 & 79,5 & 186,8 \\
3 & 29,1 & 18,2 & 22,8 & 72,9 & 51,3 \\
4 & 28,2 & 16,8 & 21,7 & 72,9 & 120,4 \\
5 & 25,6 & 14,9 & 19,6 & 76,1 & 149,8 \\
6 & 22,9 & 11,6 & 16,4 & 75,3 & 149,9 \\
7 & 24,6 & 11,5 & 17,5 & 62,3 & 39,1 \\
8 & 27,5 & 12,6 & 19,4 & 52,6 & 0,0 \\
9 & 30,3 & 15,6 & 22,3 & 53,4 & 34,7 \\
10 & 29,8 & 17,8 & 22,9 & 65,9 & 170,0 \\
11 & 30,0 & 18,0 & 23,2 & 67,0 & 132,0 \\
12 & 30,8 & 20,1 & 24,7 & 71,4 & 168,0 \\
\hline
\end{tabular}


Tabela 45. Dados meteorológicos da região de Londrina-Pr, durante a realização do trabalho: médias mensais de temperatura máxima, mínima e média $\left({ }^{\circ} \mathrm{C}\right)$, umidade relativa (\%) e total mensal de precipitação $(\mathrm{mm})$ durante o ano de 1995.

\begin{tabular}{rrrrrr}
\hline mês & t. máx. & t. mín. & t. méd. & $\begin{array}{r}\text { U.R. } \\
(\%)\end{array}$ & $\begin{array}{r}\text { Precipit. } \\
(\mathrm{mm})\end{array}$ \\
\hline 1 & 30,1 & 20,7 & 24,1 & 82,3 & 318,4 \\
2 & 28,8 & 20,1 & 23,5 & 82,6 & 285,3 \\
3 & 29,7 & 18,6 & 23,2 & 72,6 & 94,2 \\
4 & 27,8 & 15,0 & 20,6 & 67,7 & 113,9 \\
5 & 25,0 & 13,7 & 18,5 & 73,1 & 46,8 \\
6 & 24,4 & 12,6 & 17,8 & 74,6 & 56,9 \\
7 & 25,4 & 13,5 & 18,9 & 71,2 & 74,5 \\
8 & 29,2 & 14,9 & 21,5 & 54,7 & 24,1 \\
9 & 27,2 & 14,5 & 20,1 & 61,6 & 198,7 \\
10 & 26,9 & 15,2 & 20,5 & 67,8 & 216,1 \\
11 & 30,2 & 18,0 & 23,6 & 60,5 & 50,8 \\
12 & 30,4 & 19,1 & 24,2 & 66,3 & 242,3 \\
\hline
\end{tabular}

